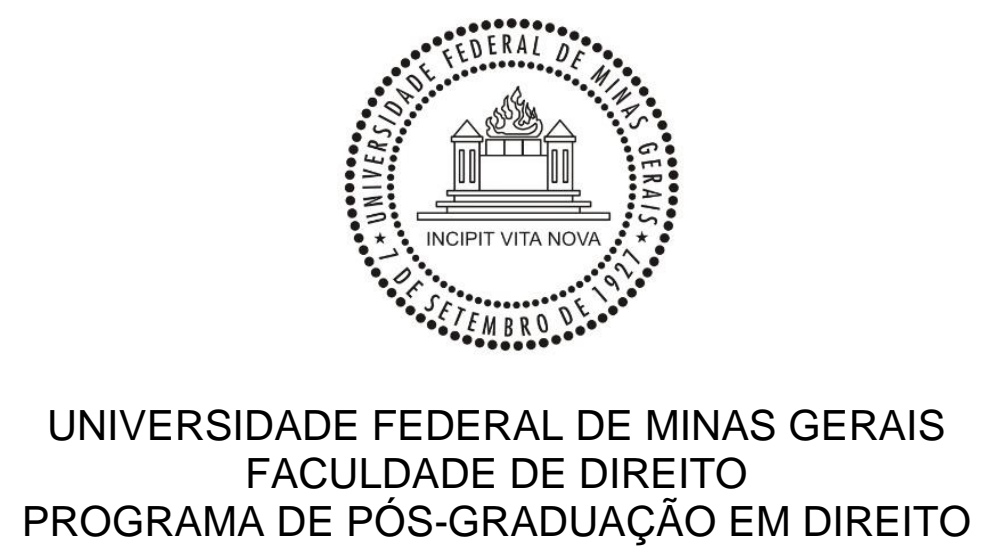

KEYLA CRISTINA FARIAS DOS SANTOS

A IMPORTÂNCIA DA ORGANIZAÇÃO DAS NAÇÕES UNIDAS PARA A AUTODETERMINAÇÃO DOS POVOS INDÍGENAS

Belo Horizonte, MG 2017 
KEYLA CRISTINA FARIAS DOS SANTOS

\title{
A IMPORTÂNCIA DA ORGANIZAÇÃO DAS NAÇÕES UNIDAS PARA A AUTODETERMINAÇÃO DOS POVOS INDÍGENAS
}

\begin{abstract}
Tese de Doutoramento em Direito apresentada, sob orientação do Professor Doutor ROBERTO LUIZ SILVA ao Programa de Pós-Graduação em Direito da Faculdade de Direito da Universidade Federal de Minas Gerais, no âmbito da Linha de Pesquisa Direitos Humanos e Estado Democrático de Direito: Fundamentos, Participação e Efetividade e do Projeto Coletivo de Pesquisa Direito e Justiça.

Pesquisa desenvolvida na Universidade Federal de Minas Gerais com financiamento integral da Coordenação de Aperfeiçoamento de Pessoal de Nível Superior (CAPES).
\end{abstract}


Dados Internacionais de Catalogação na Publicação (CIP)

Santos, Keyla Cristina Farias dos

A importância da Organização das Nações Unidas para a autodeterminação dos povos indígenas / Keyla Cristina Farias dos Santos; Orientador, Roberto Luiz Silva 2017.

198 f. il.; $29 \mathrm{~cm}$

Inclui bibliografias

Tese (Doutorado) - Universidade Federal de Minas Gerais, Faculdade de Direito, Programa de Pós - graduação em Direito, Belo Horizonte, MG, 2017.

1. Autodeterminação - Povos Indígenas. 2. Direitos indígenas. 3. Organização das Nacões Unidas. 4. Democracia. I.Silva, Roberto Luiz, orientador. II. Título.

CDD 23 ed. 341.485 
A tese intitulada A IMPORTÂNCIA DA ORGANIZAÇÃO DAS NAÇÕES UNIDAS PARA A AUTODETERMINAÇÃO DOS POVOS INDÍGENAS, da autoria de Keyla Cristina Farias dos Santos, foi considerada pela banca examinadora, composta pelos seguintes Professores Doutores:

PROFESSOR DOUTOR ROBERTO LUIZ SILVA

PROFESSOR DOUTOR AZIZ TUFFI SALIBA

PROFESSORA DOUTORA ADRIANA CAMPOS SILVA

Belo Horizonte, de de 2017. 
Ao meu pai (in memoriam), cujos ensinamentos provam que acreditar é o primeiro passo para tornar o sonho em realidade. 


\section{AGRADECIMENTOS}

Em memória ao meu ilustre pai, Pedro Paulo Farias dos Santos, e de meus ancestrais, que deixaram suas marcas indeléveis de persistência e luta por uma sociedade mais justa e igualitária, buscando terras estranhas para a realização de sonhos educacionais para a formação intelectual de seus filhos. Com muita determinação, até no dia da partida ao campo celestial, ele exigiu a retidão e os bons costumes para nosso crescimento profissional, ensinando silenciosamente o caminho da retidão para trilhar dignamente. Hoje, repousa serenamente nos braços do TodoPoderoso Pai Celestial, iluminando, seguindo e ensinando novos caminhos nunca dantes navegados no imenso mar da vida. Obrigada por tudo, sigamos sempre em frente, afinal ninguém morre enquanto permanece vivo no coração de alguém.

À minha mãe e aos meus irmãos, pelo apoio incondicional nas incertezas da vida que nos impulsionam a lutar um pouco mais a cada dia.

Ao Programa de Pós-Graduação da Faculdade de Direito da Universidade Federal de Minas Gerais (UFMG), pela magnitude de aglutinar profissionais da melhor qualidade.

À Coordenação de Aperfeiçoamento de Pessoal de Nível Superior (CAPES), pela bolsa de estudo concedida, para que houvesse a condução das pesquisas realizadas.

Aos meus professores do Doutorado Interinstitucional (DINTER) celebrado entre a Universidade Federal de Minas Gerais e a Universidade Federal do Amapá, em especial ao meu orientador, Professor Doutor Roberto Luiz Silva, que sempre exigiu o brilhantismo acadêmico, mesmo quando as tempestades da vida ousaram ofuscar a beleza do conhecimento científico. Seus ensinamentos me conduziram a seguir serenamente sempre em frente até o final da jornada.

Ao Vice-Diretor da Faculdade de Direito da UFMG, Professor Doutor Aziz Tuffi Saliba, que me recebeu no estágio docência com tamanho zelo, carinho e atenção para mais um aprendizado na sala de aula.

À Professora Doutora Adriana Campos Silva, que em seus ensinamentos sobre a educação dos direitos humanos, promove novos caminhos para a inclusão social de grande relevância no repensar da diversidade étnica e no processo constitucional de desenvolvimento social. 
Aos servidores da Universidade Federal de Minas Gerais, que iluminaram em muitos momentos o meu dia com grandiosos sorrisos e gentis palavras de afeto, em especial, ao amigo Wellerson, sinônimo de força, garra e superação.

A todos aqueles que contribuíram direta ou indiretamente, para que este árduo caminho acadêmico longe de casa fosse mais leve e suave.

Àqueles que, distante e em silêncio, acreditaram, assim como eu, que a educação é a arma mais revolucionária que todo cidadão deveria possuir para mudar sua comunicação étnica e multicultural com o mundo.

Por fim, meu sincero agradecimento aos povos indígenas da Amazônia brasileira, em especial da Tribo Indígena Arara da Volta Grande do Xingu, que no cenário da intensa exclusão social ainda acredita em uma política de desenvolvimento cultural capaz de preservar seus rituais, tradições e valores para a manutenção da vida e preservação dos ensinamentos culturais de seus antepassados. 


\section{RESUMO}

As resoluções da Assembleia Geral da Organização das Nações Unidas n. 1.514, n. 1.541 e n. 2.625 introduzem expressamente o princípio da autodeterminação dos povos como norma imperativa do Direito Internacional para proclamar o referido princípio em respeito a todos os povos. Neste trabalho, analisa-se a dimensão do princípio da autodeterminação dos povos visando à eliminação das situações coloniais e da dominação estrangeira para a livre expressão da vontade do povo, a fim de eleger a fórmula política por meio do qual se exerce o direito à autodeterminação. O princípio da autodeterminação dos povos nasceu como um conceito histórico e político antes de se transformar em um conceito de relevância jurídica, desempenhando papel muito importante no contexto da descolonização e emergindo no cenário internacional a partir da Primeira Guerra Mundial. Relativamente, a autodeterminação como direito de todos os povos trata-se da dimensão interna do princípio, possuindo uma vocação universal no sentido de que se dirige aos povos constituídos no Estado e que se vinculam ao processo democrático nacional por meio de seus governos representativos. O processo da autodeterminação dos povos resultou na fixação de um padrão que se formalizou no Direito Internacional como um princípio. Em sua primeira manifestação, como um princípio estrutural do Direito Internacional que deve servir para orientar os Estados-Membros no desenvolvimento de suas relações mútuas. Em seguida, sua relevância no âmbito interno e internacional visa garantir o direito atribuído aos povos. Ao conjugar o princípio da autodeterminação dos povos com o direito dos povos indígenas, ele pode ser entendido como o direito de um povo de decidir seu próprio destino, cultuar suas línguas e formas tradicionais de vida em observância à diversidade étnica e cultural. Dessa forma, ocorre um nexo causal entre a colonização e a alienação de terras, territórios e recursos naturais que sofreram os povos indígenas no passado e que até hoje têm vivido um processo de invisibilidade e exclusão praticamente sistemática. A chegada dos Estados republicanos na América Latina após o processo de descolonização não ocasionou uma mudança significativa na relação tradicional de sujeição e submissão a que foram submetidos os povos indígenas. Constata-se, ainda, que a inexistência de uma obrigação internacional de reconhecimento estatal das minorias deve ser interpretada como um limite à discricionariedade dos Estados para obrigações internacionais de proteção das minorias, em especial dos indígenas, pois suas reivindicações são articuladas em torno do direito da autonomia política e dos direitos especiais de representação política que lhes permitam a gestão dos próprios interesses como efetivo exercício do direito à autodeterminação dos povos.

Palavras-chave: Nações Unidas. Autodeterminação dos povos. Direitos indígenas. Democracia. Cidadania. 


\begin{abstract}
The United Nations General Assembly resolutions 1514, 1541 and 2625 expressly introduce the principle of self-determination as a peremptory norm of international law to proclaim the principle in respect of all peoples. This paper analyzes the extent of the people's self-determination principle, aiming at the elimination of colonial situations and foreign domination for the free expression of their desirability, in order to elect the political formula through which carries the right to self-determination. The selfdetermination principle was born as a historical and political concept before turning into a concept of legal relevance, performing a very important role in the decolonization context and emerging on the international scene starting from the First World War. Relatively, the self-determination as a right of all peoples refers the internal dimension of the principle, having a universal calling in the sense which is addressed toward all peoples made in the State and that are connected to the national democratic process through the existence of their representative governments. The process of self determination, resulted in setting a pattern that was formalized in international law as a principle. In its first manifestation, as a structural principle of international law, this should serve to guide Member-States in developing their mutual relations. Then its relevance in the internal and international levels is to ensure the right attributed to peoples. When is combined the self-determination principle to the right of indigenous people, it can be understood as the right of a people to decide their own destiny, worship their languages and traditional ways of life in observance of ethnic and cultural diversity. Therefore, there is a causal connection between colonization and land alienation, territories and natural resources that the indigenous peoples suffered in the past and even today, have experienced a process of invisibility and exclusion almost systematically since de days of colonization, because of the arrival of the republican states in Latin America after the process of decolonization it did not cause significant change in the traditional relationship of subjection and submission that indigenous people were submitted. It was stablished, though, the absence of an international obligation of the State recognition of minorities should be interpreted as a limit to the discretion of States to international obligations of minorities protection, in particular, indigenous people, because their demands are articulated around the political autonomy and the special rights of the political representation, that enable them to manage their own interests as an effective exercise of the right of peoples selfdetermination.
\end{abstract}

Keywords: United Nations. Peoples self-determination. Indigenous rights. Democracy. Citizenship. 


\section{LISTA DE ILUSTRAÇÕES}

Fluxograma 1 - Tipos de exercícios ao direito da autodeterminação no Século XXI.................................................................. 36

Figura 1 - Limites epistemológicos para a análise da autodeterminação....... $\quad 48$

Figura 2 - Evolução histórica do direito à Autodeterminação dos Povos........ 52

Figura 3 - Evolução jurídica do direito à Autodeterminação dos Povos.......... 53

Quadro 1 - Evolução histórica dos direitos dos povos indígenas na Organização das Nações Unidas (ONU) ................................ 110

Figura 4 - Estrutura orgânico-funcional da Organização das Nações Unidas - ONU (sentido integrado)......................................................... 138

Figura 5 - Estrutura das Nações Unidas em relação aos povos indígenas.... 139

Quadro 2 - Comparativo da matriz dos sistemas interétnicos...................... 145

Quadro 3 - Relação da Declaração das Nações Unidas sobre os Direitos dos Povos Indígenas para a garantia dos direitos pluriétnicos e multiculturais 
LISTA DE ABREVIATURAS E SIGLAS

$\begin{array}{ll}\text { AGNU } & \text { Assembleia Geral das Nações Unidas } \\ \text { AJIL } & \text { American Journal of International Law } \\ \text { ASIL } & \text { The American Society of International Law } \\ \text { CDH } & \text { Comitê de Direitos Humanos } \\ \text { CERD } & \text { Comitê para eliminação da discriminação racial } \\ \text { CIISE } & \text { Comissão Internacional sobre a Intervenção e a Soberania dos } \\ & \text { Estados } \\ \text { CIJ } & \text { Corte Internacional de Justiça } \\ \text { CPJI } & \text { Corte Permanente de Justiça Internacional } \\ \text { CRFB } & \text { Constituição da República Federativa do Brasil } \\ \text { CS } & \text { Conselho de Segurança } \\ \text { CSCE } & \text { Conselho de Segurança e Cooperação na Europa } \\ \text { CSNU } & \text { Conselho de Segurança das Nações Unidas } \\ \text { DESC } & \text { Direitos Econômicos Sociais e Culturais } \\ \text { DH } & \text { Direitos Humanos } \\ \text { FUNAI } & \text { Fundação Nacional do Índio } \\ \text { IIDH } & \text { Instituto Iberoamericano de Direitos Humanos } \\ \text { KFOR } & \text { Kosove Force } \\ \text { OIT } & \text { Organização Internacional do Trabalho } \\ \text { ONU } & \text { Organização das Nações Unidas } \\ \text { OSCE } & \text { Segurança e a Cooperação na Europa } \\ \text { OTAN } & \text { Organização do Tratado do Atlântico Norte } \\ \text { PIDSC } & \text { Pacto Internacional de Direitos Sociais e Culturais } \\ \text { PIDCP } & \text { Pacto Internacional de Direitos Civis e Políticos } \\ \text { RCEC } & \text { Revista del Centro de Estudios Constitucionales } \\ \text { REDI } & \text { Revista Española de Derecho Internacionales } \\ \text { REI } & \text { Revista de Estudios Internacionales } \\ \text { REP } & \text { Revista de Estudios Políticos } \\ \text { SDN } & \text { Sociedade de Nações } \\ \text { SPI } & \text { Serviço de Proteção ao Índio } \\ \text { UE } & \text { União Europeia } \\ \text { UHR } & \text { Universal Human Rights } \\ \text { UNDRIP } & \text { UN Declaration on the Rights of Indigenous Peoples } \\ \text { UNMK } & \text { United Nations Interim Administration Mission in Kosovo } \\ \text { UNPROFOR } & \text { United Nations Protection Force } \\ & \end{array}$


1 INTRODUÇÃO.

1.1 Justificativa e interesse acadêmico....................................................... 13

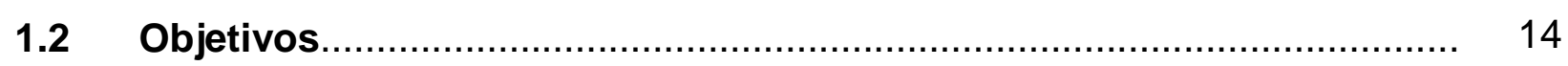

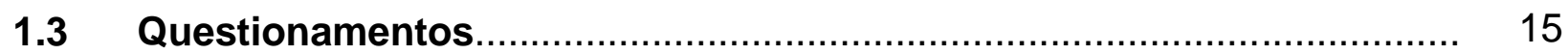

1.4 Metodologia da pesquisa e redação..................................................... 17

1.5 Complexidade da pesquisa sobre a autodeterminação dos povos........ 18

1.6 Parâmetros conceituais de minorias ........................................................ 19

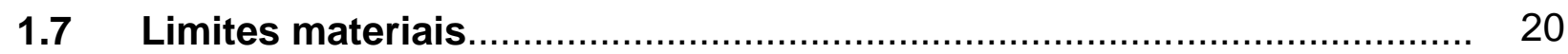

1.8 Hipóteses sugeridas....................................................................... 21

2 A AUTODETERMINAÇÃO DOS POVOS ................................................... 25

2.1 Antecedentes históricos: Lênin e Wilson............................................. 26

2.2 Surgimento da ONU e a autodeterminação dos povos............................ 29

2.3 A contribuição da Corte Internacional de Justiça.................................... 37

3 A AUTODETERMINAÇÃO E OS POVOS INDÍGENAS ............................. 48

3.1 O significado do termo autodeterminação ........................................ 50

3.2 A autodeterminação na Declaração Unilateral de Independência no Kosovo …........................................................................................ 54

3.2.1 Relevância da Declaração Unilateral de Independência no Kosovo .............. 56

3.2.2 Autodeterminação e igualdade de direitos como norma fundamental para o desenvolvimento do Estado Democrático de Direito...................................... 64

3.2.3 A intervenção humanitária para a proteção de um povo e a doutrina da responsabilidade de proteger

3.3 A internacionalização da autodeterminação dos povos indígenas para o ordenamento jurídico

4 A PROTEÇÃO INTERNACIONAL DOS POVOS INDÍGENAS NO ÂMBITO DA ORGANIZAÇÃO DAS NAÇÕES UNIDAS SOB A PERSPECTIVA DA ISONOMIA

4.1 A proteção das minorias na Declaração das Nações Unidas sobre os Direitos dos Povos Indígenas.

4.2 A proteção das minorias étnicas e o princípio da isonomia 
5 O PLURALISMO ETNO-JURÍDICO COMO POSSIBILIDADE PARA A AUTODETERMINAÇÃO DOS POVOS INDÍGENAS.

5.1 O multiculturalismo no Brasil e suas perspectivas étnicas

5.2 Pluralismo etno-jurídico e a interculturalidade indígena

6 O MULTICULTURALISMO ÉTNICO NO ESTADO BRASILEIRO E O DIREITO À IDENTIDADE CULTURAL DOS POVOS INDÍGENAS

6.1 Nos termos da Constituição de 1988, a Emenda Constitucional n. 45, de 31 de dezembro de 2004 (artigo 5ㅇ, § 3ํㅡㄹ CRF)

6.2 A consolidação de Direitos Fundamentais na Lei n. 6.001, que institui o Estatuto do Îndio.

6.3 Reconhecimento e a diversidade étnica no Estado Democrático de Direito

7 A CONSOLIDAÇÃO DA IDENTIDADE INDÍGENA E A FRICÇÃO INTERÉTNICA.

7.1 Avanços e retrocessos para a consolidação dos direitos indígenas no Estado Democrático de Direito

8 CONCLUSÃO

RECOMENDAÇÕES

REFERÊNCIAS.

ANEXOS 


\section{INTRODUÇÃO}

Os povos indígenas têm direito à
autodeterminação. Em virtude desse direito
determinam livremente sua condição política e
buscam livremente seu desenvolvimento
econômico, social e cultural (DECLARAÇÃO das
Nações Unidas sobre os direitos dos povos
indígenas, 2008).

\subsection{Justificativa e interesse acadêmico}

O princípio da autodeterminação dos povos analisado na construção desta tese fundamenta-se no conteúdo preceituado pela Carta das Nações Unidas, cujo artigo $1^{\circ}$ enfatiza o fomento entre as nações por meio das relações de amizade, baseadas no respeito ao princípio da igualdade de direitos, na autodeterminação dos povos e na tomada de medidas adequadas para fortalecer a paz universal.

Assim, a cooperação internacional para a solução dos problemas de caráter econômico, social, cultural ou humanitário, além de promover o desenvolvimento e o estímulo ao respeito dos direitos humanos e das liberdades fundamentais, sem distinção de raça, sexo, idioma ou religião, serve também, para harmonizar os esforços das nações e alcançar a garantia de direitos da pluralidade etno-jurídica dos povos indígenas na sociedade internacional.

A situação problema desenvolvida nesta pesquisa é evidenciada na ineficácia do reconhecimento internacional de afirmação da pluralidade etno-jurídica dos povos indígenas, centrada na interculturalidade e no etnodesenvolvimento, como garantia da dignidade da pessoa humana e do efetivo exercício aos direitos humanos internacionais, conforme a Declaração das Nações Unidas sobre os Direitos dos Povos Indígenas.

Esta tese possui relevância acadêmica, uma vez que na temática abordada são descritos aspectos teóricos internacionais importantes que norteiam os Estados soberanos a adotar parâmetros de acesso à justiça para as minorias étnicas, em especial os povos indígenas, a fim de garantir efetivamente seus direitos pluriétnicos e multiculturais por meio de um processo democrático. 
A relevância social da pesquisa consiste em evidenciar os processos históricos através da Carta da ONU de $1945^{1}$ e da Declaração das Nações Unidas sobre os Direitos dos Povos Indígenas de 13 de setembro de 2007², importantes fundamentos para a proteção internacional dos direitos indígenas baseados em pressupostos universalmente válidos.

Foram priorizados os aspectos relacionados aos direitos dos povos indígenas inseridos em uma política estatal indigenista, caracterizando esses grupos étnicos como minorias diferenciadas integrantes do Estado e demonstrando a ineficácia dos sistemas social, político, econômico e cultural para a efetivação das reivindicações indígenas elencadas na Carta Magna e nos ditames internacionalmente válidos.

Por fim, ilustra-se que a interculturalidade e o multiculturalismo constituem o reconhecimento das diferenças étnicas dos grupos socialmente heterogêneos, que visam à garantia de seus direitos fundamentais, bem como da superação gradativa das injustiças como consequência do processo histórico da descolonização, que incide diretamente no processo de marginalização social das minorias étnicas.

\subsection{Objetivos}

Os objetivos gerais ilustrados demonstram a importância da autodeterminação dos povos por meio da Carta das Nações Unidas para a garantia do pluralismo jurídico das populações indígenas, investigando o processo histórico da descolonização.

O objetivo específico com a pesquisa é demonstrar que a interculturalidade e o multiculturalismo são maneiras de evidenciar o problema do significado, da justificação e das consequências que o reconhecimento internacional promove como mecanismo de interação entre direitos humanos universais e direitos étnicos, fundamentos indispensáveis para a garantia da igualdade de direitos, a autodeterminação dos povos e a consolidação dos direitos humanos internacionais.

\footnotetext{
${ }^{1}$ ORGANIZAÇÃO DAS NAÇÕES UNIDAS (ONU). Assembleia Geral. Carta das Nações Unidas. Adotada e aberta à assinatura pela Conferência de São Francisco em 26 de junho de 1945. Disponível em: < https://nacoesunidas.org/carta/>. Acesso em: 31 jan. 2017.

2 ORGANIZAÇÃO DAS NAÇÕES UNIDAS (ONU). Assembleia Geral. Declaração das Nações Unidas sobre os Direitos dos Povos Indígenas, de 13 de setembro de 2007. Rio de Janeiro: Centro de Informação das Nações Unidas (United Nations Information Centre), 2008. Disponível em: <http://www.un.org/esa/socdev/unpfii/documents/DRIPS_pt.pdf>. Acesso em: 31 jan. 2017.
} 


\subsection{Questionamentos}

A) No âmbito internacional, o reconhecimento do direito à autodeterminação dos povos indígenas é o principal aspecto de controvérsia, sendo que, a autodeterminação é a expressão máxima do direito pelo qual essas minorias étnicas desenvolvem sua identidade política, econômica, social e cultural. Essa autonomia é a dimensão da autodeterminação que possibilita à descentralização do poder estatal para a tomada de decisão no âmbito local que atenda a governabilidade indígena, sendo constituída por autoridades tradicionais que buscam no conceito de povos, territórios, autodeterminação, autogoverno e direito costumeiro a inter-relação com o Direito Internacional para a defesa de seus interesses coletivos. Assim, de que modo o direito à autodeterminação dos povos e a Declaração das Nações Unidas sobre os Direitos dos Povos Indígenas promulgada pela Organização das Nações Unidas (ONU) contribuem para o reconhecimento internacional de articulação entre direitos humanos universais e direitos étnicos?

B) O movimento indígena internacional demonstra que o Pacto Internacional dos Direitos Civis e Políticos e o Pacto Internacional dos Direitos Econômicos, Sociais e Culturais concedem a todos os povos o direito à autodeterminação, inclusive aos povos indígenas, no entanto, os Estados alegam que os dispositivos que atendem aos pactos acima mencionados, referem-se apenas à autodeterminação dos Estados e que para os povos indígenas se aplicam os demais dispositivos extensivos a todos os cidadãos.

Para Anaya $^{3}$, a autodeterminação fundamenta que os direitos dos povos indígenas estão assegurados por meio da dimensão dos direitos humanos e que deles decorrem o reconhecimento da autonomia, do autogoverno e do direito costumeiro. $O$ Estado deve assegurar aos indígenas a proteção de suas culturas, territórios e riquezas naturais, bem como reconhecer o direito ao desenvolvimento a partir de seu modo de vida.

Souza Filho 4 descreve que o Pacto Internacional dos Direitos Civis e Políticos e o Pacto Internacional dos Direitos Econômicos, Sociais e Culturais estabelecem a autodeterminação como um direito dos povos, embora os Estados interpretem que se

\footnotetext{
${ }^{3}$ ANAYA, James S. Indigenous people in international law. Oxford: Oxford University Press, 2000.

${ }^{4}$ SOUZA FILHO. Carlos Frederico Marés de. O renascer dos povos indígenas para o direito. Curitiba: Juruá, 2009.
} 
trata de um direito estatal. O autor considera que os povos indígenas exercem a autodeterminação nas suas relações sociais, inclusive quando decidem por não construir um novo Estado, mas seguir com suas especificidades étnicas e culturais no Estado já constituído, ilustrando, portanto, que a autodeterminação é um direito dos povos, e não dos Estados.

Nesse sentido, existe uma efetiva igualdade no estabelecimento de ações afirmativas que se dedicam a garantir um tratamento igual e de não discriminação às populações indígenas como agentes de desenvolvimento social e cultural?

C) Os Estados resistem ou mesmo se recusam a reconhecer os direitos coletivos indígenas. Assim, os setores mais conservadores alegam que os direitos indígenas são de natureza individual e já estão protegidos pelos direitos humanos. Não se admite, portanto, incluir entre os direitos indígenas a autodeterminação, a autonomia, o autogoverno e o direito consuetudinário sob o argumento dos termos serem próprios de Estados e que, se fossem aplicados aos povos, acarretariam prejuízos à soberania estatal, possibilitando a secessão e a criação de novos Estados. Essa concepção monista e conservadora ilustra que o Estado era o único sistema jurídico, tal como defendiam os positivistas no início do século XIX.

Por outro lado, os povos indígenas argumentam que não pretendem criar novos Estados, mas promoverem a aplicação do direito para os diversos povos indígenas que historicamente ficaram excluídos da proteção jurídica e que a ONU, visando a proteção dos direitos indígenas, reconhece que a autodeterminação dos povos indígenas consiste na reforma do Estado, e não em sua divisão. Tais alegações estatais são de natureza política e demonstram a falta de interesse em acolher as reivindicações dessas minorias étnicas e de seus direitos coletivos no processo de desenvolvimento social. Dessa maneira, a articulação dos povos indígenas em torno do direito da autonomia e de seus direitos especiais de representação que permitam o desenvolvimento econômico, social e cultural por meio do direito à autodeterminação dos povos é suficiente para a garantia dos direitos humanos e liberdades fundamentalmente reconhecidas pela Carta das Nações Unidas?

D) $O$ advento da Constituição de 1988 pondo termo à política integracionista e assimilacionista no Brasil garante, efetivamente, o direito de participação dos povos indígenas no processo de desenvolvimento social, político, econômico e cultural que considere os aspectos pluriétnicos e multiculturais para a promoção democrática de 
acesso à justiça e da autodeterminação dos povos, através de uma política de desenvolvimento social integrado para as populações indígenas?

\subsection{Metodologia da pesquisa e redação}

Para a construção da tese foram adotados o método jurídico-dogmático na análise dos textos legislativos internacionais, a revisão bibliográfica e a análise de direito comparado internacional na abordagem do trabalho científico.

A construção da tese obedeceu a uma ordem de seleção bibliográfica, em seguida, foram destacados os documentos de organizações internacionais para a proteção internacional das minorias étnicas e, finalmente, foram analisadas as jurisprudências e os instrumentos internacionais citados.

A seleção bibliográfica não constituiu mera relação de fontes doutrinárias no texto, ao contrário, foram apresentadas as principais referências com as quais se construiu esta pesquisa, demonstrando o acervo doutrinário existente para a proteção das minorias étnicas, bem como para a proteção internacional dos direitos humanos.

Alguns autores, como Tomuschat ${ }^{5}$; Eagleton ${ }^{6}$; Obieta Chalbaud ${ }^{7}$; Rigo Sureda 8; Musgrave ${ }^{9}$; Piovesan ${ }^{10}$ e Trindade $^{11}$, dada a amplitude de seus trabalhos e a profundidade de suas análises provocaram inúmeras citações ao longo deste trabalho.

A seleção documental corresponde às principais Resoluções da ONU para a proteção das minorias étnicas, como a Resolução n. 61/295, aprovada em 13 de setembro de 2007, que consolidou a Declaração das Nações Unidas sobre os Direitos dos Povos Indígenas.

Finalmente, os instrumentos normativos citados ao longo da tese ilustram a relevância da temática abordada no âmbito internacional para a construção e a consolidação dos direitos indígenas por meio da autodeterminação dos povos, como

\footnotetext{
${ }^{5}$ TOMUSCHAT, C. Modern law of self-determination. Dordrecht; Boston; London: Martinus Nijhoff, 1993.

${ }^{6}$ EAGLETON, C. Self-determination in the United Nations. American Journal international Law, v. 77, 1953. p. 88-93.

${ }^{7}$ OBIETA CHALBAUD, J. A. El derecho de autodeterminación de los pueblos: un estudio interdisciplinar de derechos humanos. Bilbao: Universidade de Deusto, 1984.

${ }^{8}$ RIGO SUREDA, A. The evolution of the right of self-determination: a study of United Nations Practive. Leiden: Sijthoff, 1973.

${ }^{9}$ MUSGRAVE, T. D. Self-determination and national minorities. Oxford: Clarendon Press, 1997.

${ }^{10}$ PIOVESAN, Flávia. Direitos humanos e direito constitucional internacional. São Paulo: Max Limonad, 1997.

11 TRINDADE, Antônio Augusto Cançado. A humanização do direito internacional. Belo Horizonte: Del Rey, 2006.
} 
relevante fundamento para o patrimônio comum da humanidade e proteção da diversidade cultural.

\subsection{Complexidade da pesquisa sobre a autodeterminação dos povos}

O princípio de autodeterminação dos povos nasceu como um conceito histórico e político antes de se transformar em um conceito de relevância jurídica. Desempenhou papel muito importante no contexto da descolonização, emergindo no cenário internacional com o desfecho da Primeira Guerra Mundial.

Suas origens históricas remontam à Revolução Francesa e do território francês difundiu-se em direção a outros países europeus, como a ltália, onde assumiu a roupagem do princípio de nacionalidade ${ }^{12}$.

Os principais aspectos do princípio da autodeterminação dos povos foram enquadrados no contexto da descolonização, evidenciando o papel da ONU como supervisora dos processos de independência das colônias e da Corte Internacional de Justiça $(\mathrm{CIJ})$ na formulação de pontos jurídicos relevantes para definição do tema. A análise se desenvolveu levando em consideração o aporte fundamental trazido por Mancini ${ }^{13}$, que, ao formular o princípio de nacionalidade, contribuiu para consolidação do conceito de autodeterminação dos povos.

O conceito de autodeterminação nos meios institucionais é importante para reconstituir seu significado com base na interpretação dos textos jurídicos relevantes e propostas normativas internacionais.

A autodeterminação é um movimento social e jurídico que faz reivindicações que contestam o poder estatal e dizem respeito à construção de legitimidade política, em especial para a defesa dos interesses das minorias étnicas.

Pode ser definido como um movimento popular organizado que visa instituir mudanças estruturais fundamentais com consequências ideológicas, representacionais e/ou territoriais para um Estado ou Estados. Essa mudança pode assumir a forma da criação de uma nova entidade estatal soberana, partindo de

\footnotetext{
12 Malcom Shaw também aponta no conceito de nacionalidade a origem do princípio de autodeterminação dos povos (SHAW, Malcolm Nathan. International law. 6. ed. Cambridge: Cambridge University Press, 2008. p. 251).

13 MANCINI, Pasquale Stanislao. La teoria italiana del colonialismo. Revista del Derechos Internacionales, LXXVIII, 1985. p. 677-705.
} 
impérios, de Estados multinacionais existentes ou a substituição substancial da estrutura constitucional e funções sociais do Estado no seu território atual. Em muitos casos, as duas se combinam ${ }^{14}$.

A autodeterminação pode ser entendida como a auto-organização e o autogoverno de uma comunidade, resultando na participação popular do processo de tomada da decisão quanto aos seus princípios constitutivos e formas de organização política.

Seja internacionalmente reconhecida ou não, a autodeterminação apresenta autoridades e processos políticos que se baseiam no consentimento das populações, preservam a ordem pública, fornecem serviços sociais à comunidade, projetam uma identidade coletiva e regulam as relações externas entre os povos.

A autodeterminação como norma do sistema internacional refere-se às interpretações institucionais do conceito de autodeterminação em cada contexto histórico. Dessa maneira, existe forte tendência nas interpretações e nos documentos oficiais em restringir o alcance do direito de autodeterminação no sentido da norma jurídica, portanto, mais formal e oficial. No entanto, inúmeros grupos minoritários continuam a fazer da autodeterminação uma aspiração e um objetivo legitimador das suas lutas.

\subsection{Parâmetros conceituais de minorias}

Os textos jurídicos existentes se referem a diversos grupos de minorias consideradas nacionais, étnicas, religiosas ou linguísticas. Por minorias nacionais deve-se entender grupos minoritários com uma procedência nacional comum e uma consciência nacional que configure sua identidade étnica, independentemente do vínculo jurídico de nacionalidade a que as pessoas pertençam.

\footnotetext{
${ }^{14}$ FITZGERALD, Valpy et al (Ed.). Globalization, violent conflict and self-determination. Hampshire: Palgrave; MacMillan, 2006. p. 12: An organized popular movement which aims to institute fundamental structural changes bearing ideological, representational and/or territorial consequences for an existing state or states. This change may take the form either of the creation of a new sovereign state entity from within existing empires or multinational states, or that of the substantial replacement of the constitutional structure and social functions of the state within its present territory. In many cases the two are combined.

Tradução: Um movimento popular organizado que visa instituir mudanças estruturais fundamentais, tendo consequências ideológicas, representacionais e/ou territoriais para um Estado ou Estados existentes. Esta mudança pode assumir a forma da criação de uma nova entidade estatal soberana dentro de impérios existentes ou estados multinacionais, ou da substituição substancial da estrutura constitucional e funções sociais do Estado dentro do seu território atual. Em muitos casos, os dois são combinados.
} 
As minorias étnicas são grupos com características comuns dominantes não de sua procedência e consciência nacional, tampouco do idioma, da religião de sua identidade, mas de sua etnicidade devidamente considerada, ou seja, de sua cultura com características raciais específicas.

Por outro lado, as minorias religiosas são determinadas pela distinção entre as convicções individuais e a coisa religiosa para configuração da cultura, em que a identidade étnica está ligada por elementos religiosos.

Nesse sentido, a inexistência de uma lista concreta dos grupos reconhecidos como minoria dificulta-lhes a proteção e o reconhecimento constitucional, embora não seja uma limitação para a efetividade das normas de direitos humanos e preceitos fundamentais.

A demanda do vínculo jurídico de nacionalidade do Estado para a proteção da minoria dependerá de cada estatuto jurídico e da preservação da própria identidade, configurada como uma exigência indispensável no estabelecimento do conceito minoritário.

A inexistência de uma obrigação internacional de reconhecimento estatal das minorias deve ser interpretada como um limite à discricionariedade dos Estados para os assuntos de obrigações internacionais de proteção das suas minorias.

Nesse sentido, a condição de povo implica o reconhecimento de sua autodeterminação, autonomia e autogoverno, bem como a necessidade de proteção de seus laços culturais historicamente marginalizados e o fortalecimento das políticas públicas para a proteção das riquezas naturais, onde desenvolvem a subsistência e seus rituais étnicos.

Esses direitos coletivos devem, necessariamente, ser protegidos para as futuras gerações como garantia da dignidade dos povos indígenas, historicamente negados pelos Estados no processo de desenvolvimento social.

\subsection{Limites materiais}

Os limites materiais da tese basearam-se nos estudos realizados acerca do processo de consagração jurídica internacional dos direitos humanos, após a Segunda Guerra Mundial e a criação da ONU. 
A aprovação da Declaração Universal dos Direitos Humanos de 1948 consagrou, no âmbito internacional, preceitos de cidadania importantes para os povos indígenas, que se encontravam em situação de "invisibilidade" social como resultado de sua marginalização no processo histórico de desenvolvimento.

Nesse sentido, o reconhecimento e o exercício do direito à autodeterminação em qualquer de suas modalidades interna ou externa devem ser compreendidos como um direito à autoafirmação, à autodefinição, à autodelimitação e à autodisposição interna e externa do sujeito que a exerce.

Assim, o direito de autodeterminação consiste essencialmente na capacidade do povo de proclamar-se existente como ente constitutivo do Estado, em uma base sociológica que possui um elemento objetivo, que é a etnia, e outro subjetivo, que é a consciência étnica.

Esses fundamentos são importantes para a manifestação interna dos grupos étnicos minoritários, os quais se traduzem na possibilidade de escolher qual tipo de governo representam. Sua manifestação externa consiste na determinação de seu status político para a garantia de direitos econômicos, sociais e culturais dos povos indígenas.

A Resolução da ONU que aprova a Declaração das Nações Unidas sobre os Direitos dos Povos Indígenas e demais instrumentos internacionais vigentes que asseguram os direitos das minorias étnicas, portanto, são importantes para a garantia da autodeterminação dos povos, do pluralismo jurídico e do etnodesenvolvimento indígena.

\subsection{Hipóteses sugeridas}

As hipóteses sugeridas nesta investigação científica são:

a) Com o nascimento do Sistema Europeu de Estados, datado cronologicamente com a Paz de Westfália e o marco do Estado moderno, observamse as minorias étnicas, nacionais, religiosas ou linguísticas, com sentido moderno usado no Direito Internacional contemporâneo;

b) O sistema de proteção para as minorias articulado em torno da ONU inaugurou a proteção universal dos direitos e liberdades de todos os habitantes do Estado, podendo ser considerado como um relevante precursor do Direito Internacional para a garantia dos direitos humanos; 
c) A articulação de diferentes graus de proteção das minorias evidencia-se por meio da liberdade de culto para todos os habitantes do Estado e da proteção dos direitos e das liberdades dos cidadãos nacionais, que assegure o direito de não sofrerem discriminações por serem minoritários;

d) A ONU defende a ideia de que a proteção da dignidade da pessoa humana está baseada nas características da universalidade, objetividade e individualidade, porém a proteção das minorias será em grande parte excluída das atividades para a garantia de direitos nos primeiros anos da ONU;

e) Destaca-se a ausência de qualquer menção na Carta das Nações Unidas, que se limitou a ilustrar somente o princípio da não discriminação, sem demonstrar os relevantes aspectos da proteção para as minorias. Dessa maneira, a proteção para as minorias foi incluída nas atividades da Comissão de Direitos Humanos que criou o Subcomitê de Prevenção de Discriminações e Proteção às minorias, cuja atividade antiassimilacionista levou ao desaparecimento, por diversos anos da temática de proteção desses grupos para concentrar esforços na abordagem de prevenção das discriminações no âmbito internacional.

f) A etnicidade aparece como o critério paradigmático que permite delimitar os grupos humanos objeto de proteção como minorias. Ela se manifesta quando se refere às minorias étnicas ou culturais, nas quais há uma vinculação por meio de um idioma comum, uma cultura religiosa ou uma aspiração política nacional. Desse modo, o aspecto étnico é apresentado como o elo de conexão entre todos os elementos específicos de identidade do grupo minoritário.

Observa-se a importância da ONU para a proteção dos direitos indígenas no âmbito internacional e seus reflexos para a garantia de direitos fundamentais desses grupos étnicos nos Estados Soberanos, uma vez que a ONU possui fundamentos significativos para a construção e a consolidação do direito à autodeterminação dos povos.

Para atingir esse objetivo, nesta tese ilustra-se o processo evolutivo dos instrumentos internacionais de direitos humanos e seus reflexos sobre os direitos das minorias étnicas.

No segundo capítulo, trata-se do desenvolvimento histórico da autodeterminação dos povos e sua relação com o surgimento da ONU. 
No terceiro capítulo, descrevem-se a integração no sistema internacional contemporâneo e a implicação da autodeterminação dos povos como mecanismo para assegurar os direitos de minorias integrantes do Estado Soberano, que visa à efetiva participação no processo de desenvolvimento social, político, econômico e cultural de uma nação, tomando como exemplo a Declaração Unilateral de Independência no Kosovo.

No quarto capítulo, baseado no direito dos povos e na proteção das minorias, de acordo com os preceitos da Carta das Nações Unidas, são analisados os Pactos Internacionais de Direitos Civis e Políticos, bem como dos Direitos Econômicos, Sociais e Culturais, para a garantia dos instrumentos normativos internacionais de proteção aos direitos humanos como norteadores de direitos fundamentais no ordenamento jurídico interno.

No quinto capítulo, evidencia-se a integração da autodeterminação dos povos indígenas no âmbito da ONU, como instrumento jurídico fundamental para a consolidação dos direitos pluriétnicos e multiculturais nos Estados Soberanos.

No sexto capítulo, esse arcabouço normativo internacional subsidia o multiculturalismo nos termos da Constituição Federativa do Brasil de 1988, como fundamento para o direito à diferença e para a consolidação do direito à autodeterminação dos povos indígenas, além de explicar a incorporação dos tratados de direitos humanos no ordenamento jurídico interno, visando à consolidação dos direitos fundamentais das populações indígenas.

No sétimo capítulo, ilustra-se o reconhecimento da diversidade étnica como preceito essencial para a garantia da identidade cultural indígena no processo de desenvolvimento social e consolidação da autodeterminação dos povos indígenas.

Assim, evidencia-se a importância da autodeterminação dos povos para a garantia dos direitos indígenas à luz dos preceitos internacionais da ONU, considerado relevante instrumento de integração social para as políticas de desenvolvimento dos Estados Soberanos.

Por fim, conclui-se que os direitos pluriétnicos e multiculturais são importantes para a garantia dos direitos humanos em relação aos povos indígenas e demais minorias étnicas, além de contribuírem para o reconhecimento do pluralismo jurídico como fenômeno universal, possibilitando maior alcance do direito à diversidade capaz de construir sistemas normativos próprios da tradição cultural indígena que levem em consideração as particularidades de sua história cultural, mitologia, cosmovisão, 
formas de propriedade, uso e aproveitamento dos recursos naturais, assegurados por meio da justiça, do poder e da autoridade de concepções étnicas particulares do direito, aspectos fundamentais para a construção e consolidação de instituições próprias de desenvolvimento social indígena. 


\section{A AUTODETERMINAÇÃO DOS POVOS}

A Assembleia Geral da ONU tem sido o foro adequado para que os Estados promovam o progressivo desenvolvimento da autodeterminação dos povos.

Desde a incorporação da autodeterminação à Carta das Nações Unidas, a formulação jurídica e a aplicação desse princípio têm respondido, principalmente, à iniciativa e ao impulso dos Estados.

Os Estados têm impulsionado o processo de formulação e aplicação da autodeterminação dos povos, apresentando propostas em conformidade com as obrigações que o ordenamento jurídico internacional lhes impõem.

Nesse sentido, o papel desempenhado pelos Estados socialistas e os novos Estados Independentes levaram à definição de autodeterminação como um princípio jurídico que gera obrigações no âmbito internacional, destinado a eliminação do colonialismo, da dominação racial e da subjugação estrangeira.

$\mathrm{Na}$ atualidade, verificam-se diferentes manifestações da autodeterminação e sua identificação tem contribuído para a construção e formulação do Estado contemporâneo como o principal instrumento de organização social.

As primeiras expressões da autodeterminação contemporânea aceitaram o conceito de povo por meio das diferentes concepções de soberania. Em seguida, houve sua concepção como norma jurídica mediante as manifestações de minorias no período entreguerras e, posteriormente, evoluiu como princípio do Direito Internacional em diversos momentos históricos.

A autodeterminação esteve presente no processo de descolonização e o grande debate em torno do assunto, relaciona-se ao exercício do direito à secessão para os povos territorialmente constituído.

A evolução histórica demonstra que a autodeterminação manifesta-se de diversas maneiras, porque além de ser utilizada como fundamento para o Direito Internacional Contemporâneo, pode também ser observada nos graves casos de violações de direitos humanos, como ocorreu no Kosovo através da Declaração Unilateral de Independência.

Por fim, o presente capítulo aborda a importância do direito à autodeterminação dos povos que servirá de fundamento às populações indígenas para assegurar a consolidação dos direitos humanos, bem como garantir as demandas pluriétnicas e multiculturais no âmbito internacional. 


\subsection{Antecedentes históricos: Lênin e Wilson}

Lênin e Wilson, para contrapor as diferenças de enfoques do direito à autodeterminação no período entreguerras, abordaram de maneira geral a questão das minorias em diferentes realidades.

No primeiro momento, estavam as nacionalidades não emancipadas, ou seja, aquelas nações identificadas com fronteiras próprias e que estavam submetidas a opressão de algum império multiétnico.

No segundo momento, estavam as minorias nacionais, pequenos grupos que se encontravam dentro dos diferentes Estados e que não pertenciam a essa Nação, mas a um determinado território.

E por último, estava a dominação colonial que constituía uma forma de opressão a nacionalidades de ultramar que se diferenciavam claramente das anteriores.

Nesse sentido, uma diferença fundamental em ambos os discursos está na sua abrangência, pois no caso do Lênin seu conceito de direito à autodeterminação era bastante amplo, uma vez que ele acreditava na libertação das nacionalidades não emancipadas dos impérios, abordando a questão colonial abertamente. Destacou a utilização da autodeterminação para o direito à secessão unilateral.

Por outro lado, Wilson possuía uma visão mais limitada da autodeterminação que impulsionava a ordem internacional, enfatizando a autodeterminação exclusivamente às nações não emancipadas que se encontravam submetidas aos impérios centrais que haviam perdido a guerra.

Dessa forma, a proclamação internacional da autodeterminação ocorreu por meio do discurso dos 14 pontos do Presidente Wilson após a Primeira Guerra Mundial, em que o Império Otomano, a Áustria e a Hungria estavam em uma crise de nacionalidades.

Assim, a autodeterminação deveria ser realizada por um processo democrático através de um plebiscito para sua consolidação, fato que restringirá a 
aplicação desse direito somente para as questões coloniais, conforme se pode observar em seus famosos "14 pontos"15.

Outras considerações teóricas foram suscitadas pelos líderes Lênin e Wilson em relação a autodeterminação das minorias. Em relação a Wilson, a aplicação do direito à autodeterminação estava bastante restrito, questionando-se a validade de seus postulados, porém seu discurso gozou de maior coerência em relação ao adotado por Lênin, que estava mais dirigido em relação aos impérios centrais e às nacionalidades que o integravam ${ }^{16}$.

No entanto, Lênin conseguia harmonizar seu discurso internacionalista às classes operárias, fundamento relevante para o socialismo, quando defendeu que todas as Nações possuem o direito à autodeterminação.

Esse discurso entrou em contradição em muitos momentos, tendo em vista ser um discurso internacionalista, baseado em postulados socialistas, com um discurso nacionalista à autodeterminação ${ }^{17}$.

15 1) Inaugurar pactos de paz, depois dos quais não deverá haver acordos diplomáticos secretos, mas sim diplomacia franca e sob os olhos públicos; 2) Liberdade absoluta de navegação nos mares e águas fora do território nacional, tanto na paz quanto na guerra, com exceção dos mares fechados completamente ou em parte por ação internacional em cumprimento de pactos internacionais; 3) Abolição, na medida do possível, de todas as barreiras econômicas entre os países e o estabelecimento de uma igualdade das condições de comércio entre todas as nações que consentem com a paz e com a associação multilateral; 4) Garantias adequadas da redução dos armamentos nacionais até o menor nível necessário para garantir a segurança nacional; 5) Um reajuste livre, aberto e absolutamente imparcial da política colonialista, baseado na observação estrita do princípio de que a soberania dos interesses das populações colonizadas deve ter o mesmo peso dos pedidos equiparáveis das nações colonizadoras; 6) Retirada dos Exércitos do território russo e solução de todas as questões envolvendo a Rússia, visando assegurar melhor cooperação com outras nações do mundo. O tratamento dispensado à Rússia por suas nações irmãs será o teste de sua boa vontade, da compreensão de suas necessidades como distintas de seus próprios interesses e de sua simpatia inteligente e altruísta; 7) Bélgica, o mundo inteiro concordará, precisa ser restaurada, sem qualquer tentativa de limitar sua soberania a qual ela tem direito assim como as outras nações livres; 8) Todo território francês deve ser libertado e as partes invadidas restauradas. O mal feito à França pela Prússia, em 1871, na questão da Alsácia e Lorena, deve ser desfeito para que a paz possa ser garantida mais uma vez, no interesse de todos; 9) Reajuste das fronteiras italianas, respeitando linhas reconhecidas de nacionalidade; 10) Reconhecimento do direito ao desenvolvimento autônomo dos povos da Áustria-Hungria, cujo lugar entre as nações queremos ver assegurado e salvaguardado; 11) Retirada das tropas estrangeiras da Romênia, da Sérvia e de Montenegro, restauração dos territórios invadidos e o direito de acesso ao mar para a Sérvia; 12) Reconhecimento da autonomia da parte da Turquia dentro do Império Otomano e a abertura permanente do estreito de Dardanelos como passagem livre aos navios e ao comércio de todas as nações, sob garantias internacionais; 13) Independência da Polônia, incluindo os territórios habitados por população polonesa, que devem ter acesso seguro e livre ao mar; 14) Criação de uma associação geral sob pactos específicos para o propósito de fornecer garantias mútuas de independência política e integridade territorial dos grandes e pequenos Estados (CONHEÇA o tratado de paz de 14 pontos proposto por Woodrow Wilson. Folha Online, 2008. Disponível em: <http://m.folha.uol.com.br/mundo/2008/11/466290-conheca-o-tratado-de-paz-de-14-pontos-proposto-porwoodrow-wilson.shtml>. Acesso em: 31 jan. 2017.

${ }^{16}$ REDIN, Giuliana. Direito à autodeterminação dos povos e desenvolvimento: uma análise a partir das relações internacionais. Passo Fundo: Méritos, 2006. p. 55.

${ }^{17}$ BARBOSA, Marco Antônio. Autodeterminação: direito à diferença. São Paulo: Plêiade; Fapesp, 2001. p. 316. 
Vladimir Lênin, afirmava em suas frases revolucionárias que o socialismo era superior aos direitos das Nações à autodeterminação; por outro lado, escrevia em seu manuscrito The rights of nations to self-determination ${ }^{18}$ que as Nações possuíam o direito à autodeterminação. Lênin procurava harmonizar ambas as aspirações legítimas para servirem de instrumentos nas lutas sociais contra a libertação dos povos subjugados, apesar das reivindicações nacionais não integrarem o programa de emancipação internacional das classes operárias.

Outro aspecto relevante na diferenciação entre os discursos de Wilson e Lênin para o direito à autodeterminação refere-se o aspecto político.

Wilson destacou esse direito de modo estratégico por meio de discursos centrados na geoestratégia dos vencedores da guerra como reflexo das ações imediatas que deveriam ser realizadas naquele momento histórico, enquanto Lênin pautou-se pelo aspecto estratégico de relevância internacional da autodeterminação, incluindo os direitos das minorias, que culminou na Carta dos Direitos das Minorias, por meio da Declaração sobre a lgualdade das Nações e a salvaguarda dos direitos das minorias, de maio de $1914^{19}$ que influenciou a consolidação de outras declarações para a garantia dos direitos das minorias, como a Declaração dos Direitos das Pessoas Pertencentes a Minorias Nacionais, Étnicas, Religiosas e Linguísticas (Resolução n. 47/135 da Assembleia Geral da ONU) ${ }^{20}$.

Nesse sentido, os instrumentos internacionais editados anteriores ao Pacto Internacional Sobre os Direitos Civis e Políticos (PIDCP) de 1966, não incluíram um artigo específico destinado para os direitos das minorias. Ele foi o primeiro instrumento normativo internacional da ONU, que atendeu a temática das minorias, conforme observa-se no artigo 27 do PIDCP, em que nos Estados que existam minorias étnicas, religiosas ou linguísticas, não será negado o direito que assiste às pessoas que pertençam a essas minorias, em conjunto com os outros membros do seu grupo, a

\footnotetext{
${ }^{18}$ LÊNIN, Vladimir. The rights of nations to self-determination Journal Prosveshcheniye, n. 4-6 abr./jun. 1914. Disponível em: <https://www.marxists.org/archive/lenin/works/1914/self-det/>. Acesso em: 31 de jan. 2017.

${ }^{19}$ LÊNIN, Vladimir. Bill on the equality of nations and the safeguarding of the rights of national minorities Projeto de lei sobre a igualdade das nações e a salvaguarda dos direitos das minorias nacionais.1914. Disponível em: <https://www.marxists.org/archive/lenin/works/1914/may/00.htm>. Acesso em: 15 dez. 2016.

${ }^{20}$ ORGANIZAÇÃO DAS NAÇÕES UNIDAS (ONU). Assembleia Geral. Resolução n. 47/135, de 18 de dezembro de 1992. Declaração dos direitos das pessoas pertencentes a minorias nacionais, étnicas, religiosas e linguísticas. Disponível em: <http://direitoshumanos.gddc.pt/3_2/IIIPAG3_2_10.htm>. Acesso em: 15 dez. 2016.
} 
terem a sua própria vida cultural, a professar e praticar a sua própria religião e a utilizar a sua própria língua.

É necessária a definição do termo minoria para a construção e consolidação de suas normas internacionais de proteção, a Subcomissão para a Prevenção da Discriminação e a Proteção de Minorias, subordinada à Comissão de Direitos Humanos, pautou-se nos ensinamentos de Francesco Capotorti21 para definir minoria como um grupo numericamente inferior ao resto da população de um Estado, em posição não dominante, cujos membros sendo nacionais desse Estado possuem características étnicas, religiosas ou lingüísticas diferentes do resto da população e demonstre, pelo menos de maneira implícita, um sentido de solidariedade, dirigido à preservação de sua cultura, de suas tradições, religião ou língua.

\subsection{Surgimento da ONU e a autodeterminação dos povos}

A Declaração sobre a Concessão de Independência aos Países e Povos Coloniais (Resolução n. $1.514(\mathrm{XV})^{22}$ da Assembleia Geral da ONU, de 14 de dezembro de 1960) e da Declaração sobre os Princípios de Direito Internacional (Resolução n. 2.625 (XXV) ${ }^{23}$ da ONU, de 24 de outubro de 1970) têm sido instrumentos jurídicos relevantes para o progressivo desenvolvimento das normas de direito internacional sobre a autodeterminação.

${ }^{21}$ Francesco Capotorti. The Protection of Minorities under Multilateral Agreements on Human Rights in The Italian Yearbook of International Law, 1976, II, 14 and Study on the Rights of Persons Belonging to Ethnic, Religious and Linguistic Minorities, Geneva UN Center for Human Rights, UN Doc E/CN.4/Sub.2/384/Add.17. "A group numerically inferior to the rest of the population of a State, in a nondominant position, whose members being national of the State possess ethnic, religious or linguistic caracteristics differing from those of the resto of the population and slow, if olny implicitly, a sense of solidarity, directed towards preserving their culture, traditions,religion or language." Disponível em: <http://oppenheimer.mcgill.ca/IMG/pdf/definitions_droit_des_minorites_ethniques.pdf> Acesso em: 21 abr. 2017.

Tradução: Um grupo numericamente inferior ao restante da população de um Estado, em posição não dominante, cujos membros nacionais do Estado possuam características étnicas, religiosas ou linguísticas diferentes das do resto da população e mostrem, embora de modo implícito, um sentido de solidariedade, voltado para a preservação de sua cultura, tradições, religião ou linguagem.

22 ORGANIZAÇÃO DAS NAÇÕES UNIDAS (ONU). Assembleia Geral. Resolução n.1.514 (XV), de 14 de dezembro de 1960. Declaração sobre a concessão da independência aos países e povos coloniais. Disponível em: <http://www.dhnet.org.br/direitos/sip/onu/spovos/dec60.htm>. Acesso em: 13 dez. 2016.

${ }^{23}$ ORGANIZAÇÃO DAS NAÇÕES UNIDAS (ONU). Assembleia Geral. Resolução n. 2.625 (XXV), de 24 de outubro de 1970. Declaração sobre os princípios de direito internacional referente às relações de amizade e cooperação entre os Estados de acordo com a Carta das Nações Unidas. Disponível em: <http://www.un.org/documents/ga/res/25/ares25.htm> . Acesso em: 13 dez. 2016. 
A Declaração sobre a Concessão de Independência aos Países e Povos Coloniais e a Declaração sobre os Princípios de Direito Internacional, adaptadas por meio das Resoluções aprovadas pela Assembleia Geral das Nações Unidas, aprovadas majoritariamente pelos Estados e seguidas por uma prática internacional e proclamada nos tratados internacionais, passaram a integrar o direito consuetudinário.

Assim, a adaptação dessas declarações contribuiu para a consagração de autodeterminação como um direito dos povos e como um princípio fundamental das relações de amizade e cooperação entre os Estados.

O princípio da autodeterminação dos povos é instrumental para promover o fomento das relações de amizade entre as nações, como direito dos povos, como o direito humano e como princípio estrutural do direito internacional.

Com esse entendimento, na década de 1970, Umozurike ${ }^{24}$ demonstrou que o direito à autodeterminação é o direito que todos os povos têm de determinar seu futuro político e promover livremente seu desenvolvimento econômico, social e cultural.

Politicamente, isso se manifesta por meio da Independência, bem como pelo seu autogoverno, a autonomia local, a fusão, a associação ou alguma outra forma de participação governamental:

[...] The right of all peoples to determine their political future and freely pursue their economic, social and cultural development. Politically this is manifested through Independence, as well as self-government, local autonomy, merger, association, or some other form of participation in government $t^{25}$.

No mesmo sentido, Rigo Sureda ${ }^{26}$ afirmou que a autodeterminação poderia ser definida essencialmente como a expressão da vontade de uma comunidade sobre o seu estatuto político em relação a outras comunidades ou por sua própria organização política interna:

\footnotetext{
${ }^{24}$ UMOZURIKE, U. O. Self-determination in international law. Hamden, Connecticut: Archon Books, 1972. p. 3.

${ }^{25}$ Tradução: O direito de todos os povos de determinarem o seu futuro político e de prosseguirem livremente com o seu desenvolvimento econômico, social e cultural. Politicamente, isso se manifesta através da Independência, bem como do autogoverno, da autonomia local, da fusão, da associação ou de alguma outra forma de participação no governo.

${ }^{26}$ RIGO SUREDA, A. The evolution of the right of self-determination: a study of United Nations Practice. Leiden: Sijthoff, 1973. p. 226.
} 
Self-determination could be defined as being essentially the expression of will of a community on its political status in relation to other communities or on its own internal political organization ${ }^{27}$.

Nessa perspectiva, o entendimento de Brownlie $^{28}$ é de que a essência do direito à autodeterminação ilustra-se como o direito de uma comunidade que possui caráter distinto refletido nas instituições de governo sob o qual ele vive:

The right of a community which has a distinct character to have this character reflected in the institutions of government under which it lives The right of cohesive national groups (people's) to choose for themselves a form of political organization and their relation to other groups $^{29}$.

Na década de 1990, Przetacznik ${ }^{30}$ contribuiu para esse debate afirmando que o direito à autodeterminação pode ser definido como o direito de um povo ou de uma nação a determinar livremente, sem qualquer pressão externa, seu estatuto político e jurídico como uma entidade separada, a forma de governo da sua escolha e a forma de seu sistema econômico, social e cultural:

The right to self-determination may be defined as the right of a people or a nation to determine freely, without any outside pressure, their political and legal status as a separate entity, the form of government of their choice, and the form of their economic, social and cultural system ${ }^{31}$.

De maneira mais concisa, o internacionalista Thornberry ${ }^{32}$ declarou que a autodeterminação é o direito de todos os povos se governarem e que o autogoverno possui mais de uma dimensão ou aspecto: Self-determination is the right of all peoples

27 Tradução: A autodeterminação pode ser definida como sendo essencialmente a expressão da vontade de uma comunidade sobre o seu estatuto político em relação a outras comunidades ou sua própria organização política interna.

${ }^{28}$ BROWNLIE, I. Principles of public international law. 5. ed. Oxford: Oxford University Press, 1998. p. 599.

${ }^{29}$ Tradução: O direito de uma comunidade que tem um caráter distinto para ter esse caráter refletido nas instituições de governo sob o qual vive $\mathrm{O}$ direito dos grupos nacionais coesos (do povo) de escolherem por si próprios uma forma de organização política e sua relação com outros grupos.

${ }^{30}$ PRZETACZNIK, F. The basic collective human right to self-determination of peoples and nations as a prerequisite for peace. Law School Journal of Human Rights, New York, Part One, v. 3, 1990. p. 53-54.

31 Tradução: O direito à autodeterminação pode ser definido como o direito de um povo ou de uma nação determinar livremente, sem qualquer pressão externa, o seu estatuto político e jurídico enquanto entidade separada, a forma de governo de sua escolha e a forma de seu sistema econômico, social e cultural.

${ }^{32}$ THORNBERRY, P. The democratic or internal aspect of self-determination with some remarks on federalism. Dordrecht, London: M. Nijhoff Publishers,1993. p. 101. 
to govern themselves [...] Self-government has more than one dimension or aspect $[\ldots]^{33}$.

O Direito Internacional, de modo geral, não havia reconhecido explicitamente o direito à existência dos povos como um aspecto implícito da autodeterminação dos povos.

Esse debate surgiu no espaço Regional Africano quando a Carta Africana de Direitos Humanos e dos Povos ${ }^{34}$ proclamou, no artigo 20:

1. Todo o povo tem direito à existência. Todo o povo tem um direito imprescritível e inalienável à autodeterminação. Ele determina livremente o seu estatuto político e assegura o seu desenvolvimento econômico e social segundo a via que livremente escolheu.

2. Os povos colonizados ou oprimidos têm o direito de se libertar do seu estado de dominação recorrendo a todos os meios reconhecidos pela Comunidade Internacional.

3. Todos os povos têm direito à assistência dos Estados Partes na presente Carta, na sua luta de libertação contra a dominação estrangeira, quer esta seja de ordem política, econômica ou cultural.

José de Obieta Chalbaud"35 apontou que "quando o povo enquanto coletividade de pessoas se caracteriza específica e principalmente pela sua cultura, o direito de existência significa prioridade, embora não exclusivamente, no direito à manutenção e desenvolvimento da cultura".

A tutela desses direitos é uma questão levantada de forma expressa com relação às populações indígenas. Dessa forma, Martínez Cobo, Relator Especial da Subcomissão de Prevenção da Discriminação e Proteção das Minorias afirma:

Os povos indígenas têm direito natural inalienável de preservar a posse dos seus territórios e reivindicar as terras nas quais eles têm sido despossuídos, ou seja, têm o direito do patrimônio natural e cultural que o território contém, a fim de determinar livremente a utilização e a exploração deste ${ }^{36}$.

\footnotetext{
33 Tradução: A autodeterminação é o direito de todos os povos de se governarem [...] O governo autônomo tem mais de uma dimensão ou aspecto.

${ }^{34}$ COMISSÃO Africana dos Direitos Humanos e dos Povos. Carta Africana de Direitos Humanos e dos Povos. Disponível em: <http://www.achpr.org/pt/instruments/achpr>. Acesso em: 9 dez. 2016.

35 OBIETA CHALBAUD, 1984, p. 88. "Cuando el pueblo como comunidad de personas se caracteriza específicamente y principalmente por su cultura, el derecho a existir medios prioridad, pero no exclusivamente, el derecho a mantener y desarrollar la cultura." Tradução: Quando o povo enquanto coletividade de pessoas se caracteriza específica e principalmente pela sua cultura, o direito de existência significa prioridade, embora não exclusivamente, no direito à manutenção e desenvolvimento da cultura.

${ }^{36}$ MARTÍNEZ COBO, J. R. Estudio del problema de la discriminación contra las poblaciones indígenas. Doc./CN.4/Sub.2/1986/7/Add. 4, v. 5, p. 17, § 198, p. 40-41. 1987. Disponível em: <http://www.derechos.org/nizkor/bolivia/doc/coboes.html>. Acesso em: 9 dez. 2016.
} 
A Subcomissão de Prevenção contra a Discriminação e Proteção dos Povos ${ }^{37}$, em especial das minorias étnicas, observou que eles têm o direito de retornar à sua terra natal e de preservar seus espaços culturais como garantia de seu direito à existência como fator implícito do princípio da autodeterminação dos povos, conforme preceitua o art. 3o da Declaração Universal dos Direitos dos Povos: "Todo povo tem direito de conservar a posse pacífica do seu território e de retornar a ele em caso de expulsão"38.

Ruiloba Santana ${ }^{39}$ afirma que o direito à "terra natal" terá relevância como expressão da necessidade de respeitar a integridade territorial de uma nação que ainda não conseguiu ou está em processo de realização da sua independência.

Obieta Chalbaud ${ }^{40}$ defende que para o exercício da autodeterminação, os povos devem manter-se ao lado do direito à existência e do direito de igualdade, sendo essa a justificativa que apoia o direito de autodeterminação como um processo que zela pela igualdade e ética de todos os povos.

Assim, a Resolução n. 2.625 (XXV) da Assembleia Geral da ONU ${ }^{41}$ estabelece o exercício do direito à autodeterminação como:

o estabelecimento de um Estado Soberano e Independente, a livre associação ou integração com um Estado Independente ou a aquisição de qualquer outra condição política livremente decida pelo povo.

Os deveres genéricos que acompanham a Resolução n. 2.625 (XXV) são:

a) a obrigação de cooperar com a promoção do princípio supracitado e de assistir as Nações Unidas para aplicação do mesmo;

b) a obrigação de promover o respeito e a efetividade dos direitos humanos e liberdades fundamentais, prevista no parágrafo terceiro da referida resolução e cuja sua inclusão compreende somente quando o povo decida livremente seu próprio destino;

c) a obrigação deve abster-se de recorrer de qualquer medida de força que prive os povos do exercício de direito à autodeterminação.

\footnotetext{
37 DECLARAÇÃO Universal dos direitos dos povos de 1976. Disponível em: <http://www.dhnet.org.br/direitos/sip/ textos/direitos_povos.html>. Acesso em: 9 dez. 2016.

${ }^{38}$ ORGANIZAÇÃO DAS NAÇÕES UNIDAS, 1970.

${ }^{39}$ RUILOBA SANTANA, E. Una nueva categoría en el panorama de la subjetividad internacional: el concepto de pueblo: estudos de direito internacional. Homenagem ao Professor Miaja de la Muela, Madrid: Tecnos, 1979. v. 1, p. 332.

${ }^{40}$ OBIETA CHALBAUD, 1984. p. 74.

${ }^{41}$ ORGANIZAÇÃO DAS NAÇÕES UNIDAS, 1970.
} 
A Declaração sobre a Concessão de Independência dos Países e dos Povos Coloniais, por meio da Resolução n.1.514 (XV), de 14 de dezembro de 1960²:

A sujeição dos povos a uma subjugação, dominação e exploração estrangeira constituía uma negação dos direitos humanos fundamentais que contraria a Carta das Nações Unidas e compromete a causa da paz e a cooperação mundial.

Nesse sentido, a caracterização da autodeterminação como um princípio fundamental do Direito Internacional só faz sentido se houver igualdade de direitos entre os povos capaz de determinar livremente sua condição do direito à autodeterminação.

$\mathrm{O}$ art. 19 da Carta Africana dos Direitos Humanos e Povos ${ }^{43}$ declara: "Todos os povos são iguais, gozam da mesma dignidade e têm os mesmos direitos. Nada pode justificar a dominação de um povo por outro".

As formulações mais relevantes do direito à autodeterminação coincidem com o fato de que os povos podem determinar ou definir sua condição política e prosseguir seu desenvolvimento econômico, social e cultural.

O Estado deve promover, por meio de ações conjuntas ou individuais, o respeito e a efetividade universal dos direitos humanos e das liberdades fundamentais, embora a determinação da condição política seja o fundamento e o conteúdo essencial do direito à autodeterminação.

Dessa maneira, o estabelecimento do Estado Soberano e independente, a livre associação e a aquisição de qualquer outra condição política livremente decidida por um povo constituem formas de exercício do direito à autodeterminação.

A proteção do direito à autodeterminação dos povos em seu âmbito interno relaciona-se com a configuração de sistemas e procedimentos internacionais de proteção a democracia, com respeito aos direitos humanos internacionais.

Assim, a dimensão interna do princípio da autodeterminação dos povos constitui a integração do povo ao Estado democrático que reconheça sua existência e permita sua efetiva participação no exercício da vontade política governamental, reconhecendo os direitos das minorias.

\footnotetext{
${ }^{42}$ ORGANIZAÇÃO DAS NAÇÕES UNIDAS (ONU), 1960. Resolução n. 1.514 de dezembro de 1960. Disponível em: 〈http://www.dhnet.org.br/direitos/sip/onu/spovos/dec60.htm〉. Acesso em: 20 abr. 2017.

${ }^{43}$ CARTA Africana de Direitos Humanos. Disponível em: <http://www.achpr.org/pt/instruments/achpr/>. Acesso em: 9 dez. 2016.
} 
A dimensão interna está diretamente vinculada ao conceito de democracia, que tem sua expresssão na Declaração da Conferência de Viena sobre Direitos Humanos de $1993^{44}$, na qual se afirma que a democracia se baseia na vontade do povo e na livre expressão para determinar seu regime político, econômico, social e cultural $^{45}$, haja vista que os direitos fundamentais não são regidos pelas normas, mas as normas regidas por estes ${ }^{46}$.

Já a dimensão externa do direito à autodeterminação dos povos consiste em poder afirmar sua identidade no âmbito internacional para garantia de direitos. Estando vinculado a soberania e é externo aos Estados e seus titulares são os povos colonizados.

Sendo que, seu exercício materializa-se pela independência, conforme os preceitos da Resolução 1.514 supramencionada, através da livre associação ou livre integração aos Estados, estabelecida na Resolução 1.541 ou qualquer forma livremente decidica pelo povo, de acordo com a Resolução 2.625.

44 DECLARAÇÃO e Programa de Ação de Viena. 1993. Disponível:< https://www.oas.org/dil/port/1993\%20Declara\%C3\%A7\%C3\%A3o\%20e\%20Programa\%20de\%20Ac\%C3\% A7\%C3\%A3o\%20adoptado\%20pela\%20Confer\%C3\%AAncia\%20Mundial\%20de\%20Viena\%20sobre\%20 Direitos\%20Humanos\%20em\%20junho\%20de\%201993.pdf>. Acesso em: 9 dez. 2016.

45 PROGRAMA de ação da Declaração de Viena. Disponível em:< http://www.pge.sp.gov.br/centrodeestudos/bibliotecavirtual/instrumentos/viena.htm>. Acesso em: 14 abr. 2017.

46 FERRAJOLI, Luigi. La democracia através de los derechos: el constitucionalismo garantista como modelo teórico y como proyecto político. Madrid: Trotta. 2014. p. 80. 
Fluxograma 1 - Tipos de exercícios ao direito da autodeterminação no Século XXI.

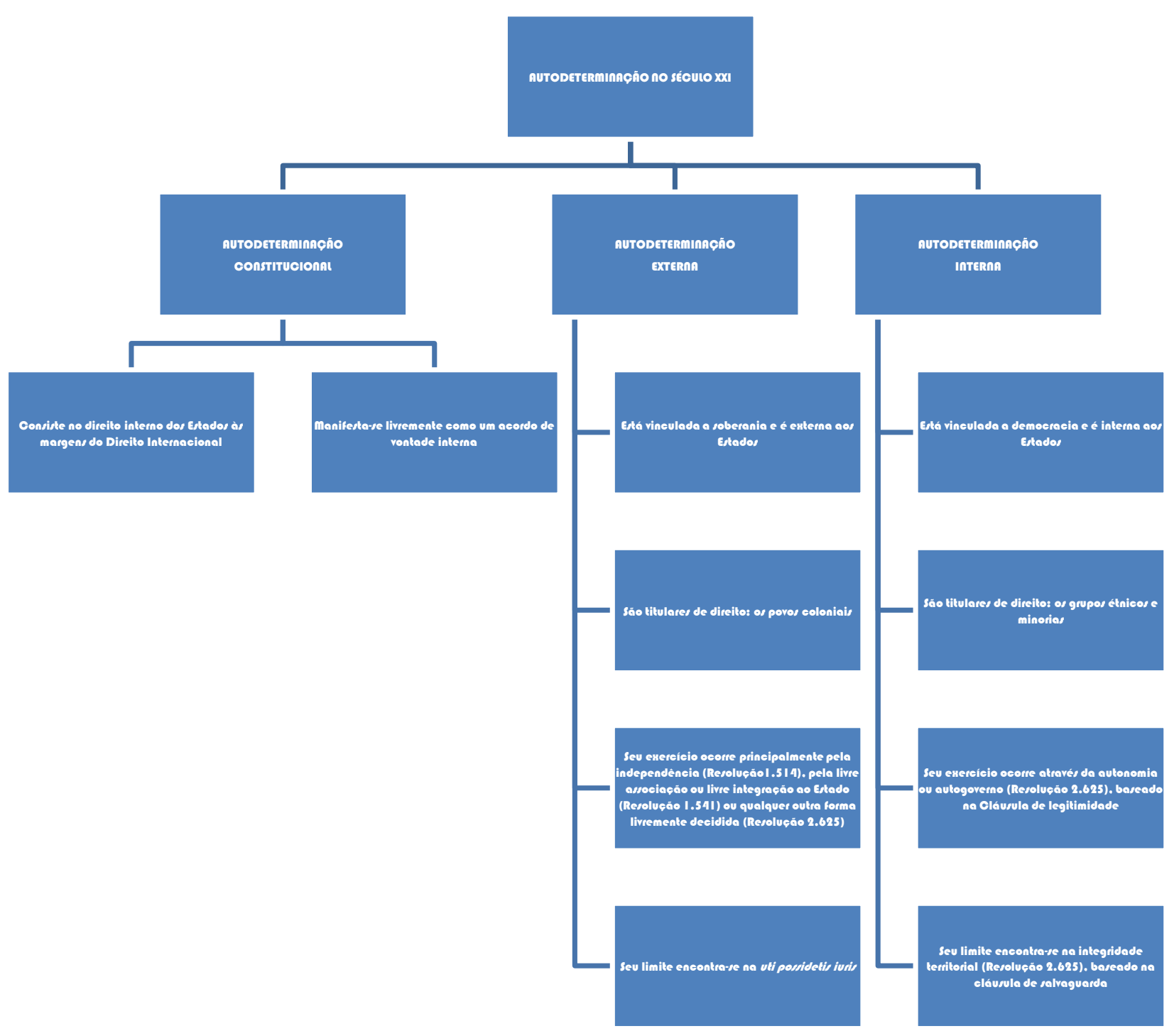

Fonte: Elaborado pela autora (2017). 


\subsection{A contribuição da Corte Internacional de Justiça}

A Conferência de San Francisco de 1945 estabeleceu a criação de um novo Tribunal Internacional com a consolidação da Corte Internacional de Justiça (CIJ), juntamente com as Nações Unidas.

O artigo 92 da Carta das Nações Unidas considera a ClJ, o principal órgão jurisdicional das Nações Unidas que grandiosamente contribuiu para a ampliação do conceito de autodeterminação, a fim de torná-lo um conceito jurídico, além dos ditames políticos ora empregados no período da colonização pela comunidade internacional ${ }^{47}$.

A consolidação do Estatuto da CIJ pautou-se amplamente no antigo Estatuto da Corte Permanente de Justiça Internacional (CPJI), redigido anteriormente pelo Comitê Consultivo de Juristas convocado pela Liga das Nações em 1920.

Apesar da Liga das Nações iniciar a criação da CPJI, esta não se integrou à Liga, pois a atual ClJ faz parte das Nações Unidas e o seu Estatuto é parte integrante da Carta das Nações Unidas, devendo ambos serem adotados com um todo ${ }^{48}$.

Em abril de 1946, com a dissolução formal da Corte Permanente de Justiça Internacional (CPJI), a Corte Internacional de Justiça (CIJ) se reuniu pela primeira vez, passando a funcionar permanentemente no Palácio da Paz em Haia.

Compõe-se de 15 juízes, eleitos pela Assembleia Geral e pelo Conselho de Segurança das Nações Unidas, sendo que é proibida a existência de dois juízes de nacionalidade do mesmo Estado.

Exerce tanto a função contenciosa como consultiva, sendo que no primeiro caso é responsável pela solução de controvérsias internacionais submetidas ao seu conhecimento pelos Estados em litígio.

A contribuição da Corte Internacional de Justiça (ClJ) para a autodeterminação dos povos foi o reconhecimento desta como um direito, e não apenas como uma aspiração política, em relação ao contexto da descolonização e seus reflexos além desse momento histórico, que poderá ser reivindicado também pelos povos não coloniais.

\footnotetext{
47 ZYBERI, Gentian. Self-determination through the Lens of the International Court of Justice. Netherlands International Law Review. v.56, p. 431-453, 2009, Disponível em: <http://dx.doi. org/10.1017/S0165070X0900429X>. Acesso em: 14 maio 2017.

48 TRINDADE, Antônio Augusto Cançado. Os Tribunais Internacionais e a realização da Justiça. 2. ed. ampl. Belo Horizonte: Del Rey, 2017. p.18.
} 
A autodeterminação auxiliou externamente o processo de independência, integração e associação a um Estado independente das populações de territórios que eram coloniais.

Além do contexto da descolonização, o princípio da autodeterminação obteve grande relevância quanto direito, à medida que a Corte Internacional de Justiça (CIJ) realizou de maneira integrada os conteúdos das resoluções da Assembleia Geral da ONU como prática de Direito Internacional a ser consolidado pelos Estados.

Nesse sentido, os pronunciamentos da Corte Internacional de Justiça e os trabalhos realizados no âmbito da Comissão de Direito Internacional consolidam a existência de uma opinio juris ${ }^{49}$, fazendo com que o princípio da autodeterminação dos povos seja considerado uma norma aceita e reconhecida pelo Direito Internacional, só podendo ser modificada por uma nova norma geral de mesma natureza.

Nesse sentido, as resoluções da Assembleia Geral da ONU $1.514(\mathrm{XV})^{50}$, $1.541(\mathrm{XV})^{51}$ e $2.625(\mathrm{XXV})^{52}$ introduzem expressamente o princípio da autodeterminação dos povos como norma imperativa do Direito Internacional, bem como o artigo $1^{\circ}$ dos Pactos de Direitos Humanos de 1966, possuindo o mesmo conteúdo para proclamar o referido princípio em respeito a todos os povos.

A dimensão do princípio da autodeterminação dos povos visa à eliminação das situações coloniais e de dominação estrangeira para a livre expressão da vontade do povo, a fim de eleger a fórmula política por meio da qual se exerce seu direito à autodeterminação, ainda que a Resolução $1.514(\mathrm{XV})^{53}$, na prática, inclina-se para a

${ }^{49}$ REVISTA DA FACULDADE DE DIREITO DA UFMG. Fontes do Direito Internacional: Opinio Juris - É considerado um dos elementos constitutivos da norma internacional que assegura os costumes, pressupondo uma existência de regra jurídica autônoma, independente da regra que confere aos atos exteriores a qualidade de normas jurídicas. p. 22-34. Disponível em: <https://www.direito.ufmg. br/revista/index.php/revista/article/viewFile/580/547>. Acesso em: 14 maio 2017.

50 ORGANIZAÇÃO DAS NAÇÕES UNIDAS (ONU). Assembleia Geral. Resolução n.1.514 (XV), de 14 de dezembro de 1960. Declaração sobre a concessão da independência aos países e povos coloniais. Disponível em: <http://www.dhnet.org.br/direitos/sip/onu/spovos/dec60.htm>. Acesso em: 13 maio 2017.

51 ORGANIZAÇÃO DAS NAÇÕES UNIDAS (ONU). Assembleia Geral. Resolução n.1.541 (XV), de 15 de dezembro de 1960. Disponível em: <http://www.un.org/documents/ga/res/15/ares15.htm>. Acesso em: 13 maio 2017.

52 ORGANIZAÇÃO DAS NAÇÕES UNIDAS (ONU). Assembleia Geral. Resolução n. 2.625 (XXV), de 24 de outubro de 1970. Declaração sobre os princípios de direito internacional referente às relações de amizade e cooperação entre os Estados de acordo com a Carta das Nações Unidas. Disponível em: < http://www.un.org/documents/ga/res/25/ares25.htm> . Acesso em: 13 maio 2017.

${ }^{53}$ ORGANIZAÇÃO DAS NAÇÕES UNIDAS (ONU), 1970. 
descolonização por meio da independência, em respeito ao princípio da integridade territorial.

A autodeterminação como direito de todos os povos constitui a dimensão interna do princípio, possuindo uma vocação universal no sentido de que se dirige ao conjunto dos povos constituídos no Estado, vinculados ao processo democrático nacional mediante a existência de seus governos representativos ${ }^{54}$.

Por outro lado, têm uma perspectiva econômica centrada no direito dos povos de disporem livremente de suas riquezas e de seus recursos naturais.

No artigo 9 do Estatuto da Corte Internacional de Justiça (CIJ), assinado em São Francisco, no dia 26 de junho de 1945 com entrada em vigor no dia 24 de outubro de 1945, observa-se que na composição da Corte se exige a devida representação dos principais sistemas jurídicos do mundo, assim como a presença dos eleitores para que possam individualmente realizarem suas exigências no acesso à justiça.

Dessa maneira, o direito dos povos se constrói levando em consideração os sistemas jurídicos nacionais integrados aos interesses universais do Direito Internacional para a garantia dos direitos humanos.

Consubstanciado nas políticas de desenvolvimento social, o direito dos povos pode assegurar as minorias étnicas relevantes fundamentos para sua melhor inserção social, a fim de que o aspecto cultural seja um relevante instrumento de universalização das diversidades pluriétnicas e multiculturais.

Os princípios gerais do direito integrantes dos sistemas jurídicos nacionais, preceituados na Carta da ONU são relevantes fundamentos para o Direito Internacional consolidar a manifestação jurídica universal de direitos dos povos, considerados pressupostos básicos da humanidade e que exercem um papel muito importante no Estado democrático de direito, para a consolidação dos direitos fundamentais de grupos historicamente marginalizados, como as populações indígenas.

\footnotetext{
${ }^{54}$ HIGGINS, Rosalyn. Human Rights in the International Court of Justice. Leiden journal of international Law, v. 20, 2007. p. 751. Disponível em: <https://www.cambridge.org/core/journals/ leiden-journal-of-internationallaw/article/human-rights-in-the-international-court-ofjustice/24A0AD2B3486F3D9709622C46A3A9D7E\#>. Acesso em: 14 maio 2017.
} 
Os imperativos positivistas no ordenamento jurídico cedem espaço a esses pressupostos que expressam o direito dos povos através da ideia de justiça, considerada relevante fundamento para a universalização e aplicação do Direito Internacional.

O artigo 38 do Estatuto da Corte Internacional de Justiça (CIJ) elenca as fontes formais do direito como costumes, tratados, princípios gerais do direito, jurisprudência, doutrina e equidade, sendo que tal enumeração não é exaustiva, e sim ilustrativa, porque além da formal manifestação do Direito Internacional existem outras fontes de igual consideração, como os atos jurídicos unilaterais dos Estados e Resoluções das Organizações Internacionais.

O processo da autodeterminação dos povos resultou na fixação de um padrão que se formalizou no Direito Internacional como um princípio e como direito. Em sua primeira manifestação, como um princípio estrutural do Direito Internacional, a autodeterminação dos povos deve servir para orientar os Estados-Membros no desenvolvimento de suas relações mútuas. E, além disso, no âmbito principiológico, a autodeterminação tem uma segunda demonstração que é a sua formação como um direito atribuído aos povos.

Salientando-se que, a enumeração do artigo 38 nos termos do Estauto em questão, rege-se desde 1920 quando o Comitê Consultivo de Juristas da Liga das Nações a adotou e quem eluindo gradativamente na abrangência de direitos dos povos, pautados nos pressupostos do Direito Internacional.

A Carta da ONU em seu artigo 80, parágrafo 1, refere-se aos "direitos dos povos" dos territórios não autônomos, que se desenvolveu progressivamente no âmbito do Direito Internacional, consagrando a aplicação da autodeterminação a todos os territórios autônomos ou não.

Nesse sentido, a Corte Internacional de Justiça (CIJ) estabeleceu esse entendimento da autodeterminação externa como uma prática internacional, transformando-se em uma regra de direito costumeiro, nos termos da Carta da ONU e declaração de $1960^{55}$, que considerava todos os povos e territórios que não tinham alcançado a independência.

55 ORGANIZAÇÃO DAS NAÇÕES UNIDAS (ONU). Assembleia Geral. Resolução n.1.514 (XV), de 14 de dezembro de 1960. Declaração sobre a concessão da independência aos países e povos coloniais. Disponível em: 〈http://www.dhnet.org.br/direitos/sip/onu/spovos/dec60.htm〉. Acesso em: 14 maio 2017. 
Sendo que, a autodeterminação externa vincula a soberania dos povos garantindo sua não dominação e impedindo qualquer forma arbitrária de submetimento popular.

Possui vinculação ao processo de descolonização, à medida que o povo colonial pode se determinar contrário a qualquer forma de opressão externa que esteja submetido como consequência de sua dominação colonial.

Portanto, a autodeterminação externa é um processo do Estado em decidir de modo interestatal, onde o povo configura sua independência como país contrário à dominação externa de outro Estado.

Com a positivação da Carta das Nações Unidas em 1945, em resposta as situações coloniais acima elencadas, o princípio da autodeterminação dos povos possibilitou por intermédio de resoluções da Assembleia Geral das Nações Unidas, como a n. 1.514 se referindo ao processo de independência e a n.1.541 conferindo aos povos coloniais sua autodeterminação, através da livre associação ou integração com outro Estado, através da materialização do princípio na Carta, possibilitando um verdadeiro processo de descolonização, que liberou grande parte dos povos submetidos ao colonialismo.

Além da resolução n. 2.625 de 1970, que adicionou mais uma possibilidade de autodeterminação externa, através da aquisição de qualquer outra condição política livremente decidida pelo povo, para acabar com a dominação colonial o qual o povo era submetido.

O povo colonial exerce o direito da autodeterminação externa, quando possui o direito de decidir sobre seu futuro com a emissão voluntária de sua vontade na realização da independência, associação ou qualquer outra forma de integração.

Porém, um limite expresso ao exercício do direito da autodeterminação externa nas situações coloniais, consiste a não violação do princípio uti possidetis iuris $^{56}$, em respeito as fronteiras coloniais previamente estabelecidas.

Nesse sentido, o princípio uti possidetis iuris havia sido afirmado continuamente como princípio expresso à autodeterminação externa ao processo de descolonização.

\footnotetext{
${ }^{56}$ Um limite reconhecido pela própria Corte Internacional de Justiça - CIJ em sua jurisprudência como princípio geral regulador do processo de descolonização. Sentença CIJ: Caso acerca da disputa de fronteira (Burkina Faso x República de Mali), de 22 de dezembro de 1986. Disponível em: < http://www.dipublico.org/cij/doc/80.pdf> Acesso em: 17 maio 2017.
} 
Portanto, a Assembleia Geral das Nações Unidas estabeleceu a necessidade de se respeitar rigorosamente a unidade nacional e a integridade territorial de um território colonial no momento da obtenção de sua independência ${ }^{57}$.

Da mesma maneira, outras organizações regionais como a Organização para a Unidade Africana (OUA), se pronunciaram a favor do princípio uti possidetis iuris, afirmando que as fronteiras são imutáveis ${ }^{58}$ :

[...] Gobierno proclama su entera adhesión al principio fundamental de las relaciones internacionales, según el cual la soberanía y la integridad territoriales de todos los Estados grandes y pequeños son inviolables y deben ser respetadas ${ }^{59}$.

O caso referente a delimitação fronteiriça entre Burkina Faso e República de Mali, estabelecendo como limite o princípio de uti possidetis, através das fronteiras coloniais, ao afirmar que:

A primera vista este principio entra en conflicto directo con outro, el derecho de los pueblos a la autodeterminación. Sin embargo, el mantenimiento del status quo territorial en África es a menudo visto como la forma de proceder más acertada, para preservar lo logrado por los pueblos que han luchado por su independencia, y para evitar una interrupción que privaría el continente de las ganancias logradas con mucho sacrificio ${ }^{60}$.

Dessa maneira, se afirma que a autodeterminação externa no âmbito colonial, ao se relacionar com o princípio uti possidetis exista um claro entendimento que, após a realização da independência de um território colonizado não poderá ocorrer secessão unilateral do mesmo, posteriormente.

${ }^{57}$ ORGANIZAÇÃO DAS NAÇÕES UNIDAS (ONU). Assembléia Geral. 34 Sessão. ONU. Resolução 34/91 de 12 de dezembro de 1979. Questão das Ilhas Gloriosas, Juan de Nova, Europa. Disponível em: < http://www.un.org/es/comun/docs/?symbol=A/RES/34/91>. Acesso em: 17 maio 2017.

${ }^{58}$ Organização para a Unidade Africana (OUA). Resoluções e declarações sobre a descolonização. Resolução sobre conflitos fronteiriços de $1964 . \quad$ Disponível em: http://www.usc.es/export9/sites/webinstitucional/gl/institutos/ceso/descargas/OUA_AHG_Res-16-I1964_es.pdf>. Acesso em: 17 maio 2017.

59 Tradução: “Governo proclama sua inteira adesão ao princípio fundamental das relações internacionais, segundo o qual a soberania e a integridade territorial de todos os Estados grandes e pequenos são invioláveis e devem ser respeitados".

60 Tradução: À primeira vista este princípio entra em conflito direto com outro, o direito dos povos à autodeterminação. No entanto, a manutenção do status quo territorial na África é muitas vezes visto como o caminho a seguir mais bem sucedido, para preservar as conquistas dos povos que lutaram por sua independência, e para evitar a interrupção que privaria o continente dos ganhos obtidos com grande sacrifício. 
A Corte Internacional de Justiça (CIJ) ressalta também, a necessidade de se realizar a consulta popular seja através de plebiscito ou referendo, para averiguar a vontade do povo na aplicação do princípio da autodeterminação dos povos, em relação aos territórios não autônomos.

E a Resolução n. 1.514 (XV), de 14 de dezembro de 1960 da Assembleia Geral da ONU, em que institui a Declaração sobre a Concessão da Independência aos Países e Povos Coloniais, generaliza o princípio da autodeterminação e exige que a vontade popular seja atendida nos casos de integração e associação dos povos a um Estado independente.

Esse entendimento ampliou o significado do princípio da autodeterminação dos povos aplicado às antigas instituições jurídicas, não podendo ser concebido de modo estático, mas dinâmico e sendo interpretado no bojo de cada ordenamento jurídico da época em questão.

Por outro lado, a Corte Internacional de Justiça além da função contenciosa acionada somente pelos Estados em litígio, a mesma também exerce a função consultiva, emitindo Pareceres acerca de questões jurídicas quando solicitada por organismos internacionais que são os órgãos principais das Nações Unidas como: Assembleia Geral, Conselho de Segurança e o Conselho Econômico e Social das Nações Unidas (ECOSOC), assim como as agências especializadas como a Organização Internacional do Trabalho (OIT), a Organização Mundial de Saúde (OMS) e Organização das Nações Unidas para a Educação, Ciência e Cultura (UNESCO), de acordo com os preceitos do artigo 65 do Estatuto da CIJ, vejamos:

A Corte poderá dar parecer consultivo sobre qualquer questão jurídica a pedido do órgão que, de acordo com a Carta nas Nações Unidas ou por ela autorizado, estiver em condições de fazer tal pedido.

As questões sobre as quais for pedido o parecer consultivo da Corte serão a ela submetidas por meio de petição escrita, que deverá conter uma exposição do assunto sobre o qual é solicitado o parecer e será acompanhada de todos os documentos que possam elucidar a questão ${ }^{61}$.

A Corte Internacional de Justiça compartilha esse entendimento, em que se deva levar em consideração a vontade do povo nos casos de situações que envolvam

61 ESTATUTO DA CORTE INTERNACIONAL DE JUSTIÇA (CIJ). Disponível em: <http://www. direitoshumanos.usp.br/index.php/Corte-Internacional-de-Justi\%C3\%A7a/estatuto-da-corte-internacional-dejustica.html>. Acesso em: 14 maio 2017. 
alterações em territórios de Estados, deixando também, uma parcela de discricionariedade à Assembleia Geral da ONU, no que pertine a realização das formas e procedimentos os quais serão realizados para a consolidação da autodeterminação do povos.

Como toda norma jurídica, a autodeterminação dos povos tem como efeito a criação, a modificação ou a extinção de direitos e obrigações, que são atribuídos aos proprietários da autodeterminação.

Nesse sentido, o conteúdo jurídico da autodeterminação é dividido em duas partes: o direito dos povos à autodeterminação e as obrigações dos Estados-Membros nessa matéria.

Inicialmente, analisa-se o direito dos povos à autodeterminação sob duas dimensões: a dimensão política e a dimensão econômica, social e cultural. Em seguida, analisa-se a formulação da autodeterminação como um princípio estruturante do Direito Internacional para as obrigações dos Estados-Membros e promoção das Relações de Amizade e Cooperação.

Dessa maneira, os Estados devem respeitar o direito dos povos à autodeterminação promovendo a implementação do princípio da igualdade de direitos e, finalmente, de não reconhecerem situações que violem a autodeterminação dos povos.

No pronuncimento do juiz Dillard no parecer consultivo requerido pela Assembleia Geral das Nações Unidas sobre duas questões relativas ao território do Sahara Ocidental. Sendo que a primeira consideração estaria relacionado a questão se o Sahara Ocidental (Rio de Oro e Sakiet El Hamra) no perído da colonização espanhola era considerada "terra nullius"? E a outra consideração, era estabelecer quais os vínculos jurídicos entre esse território e o Reino de Marrocos e a entidade da Mauritânia?

No primeiro questionamento, a Corte entendeu que o Sahara Ocidental não era considerado "terra nullius". E no segundo questionamento, a decisão unânime da Corte era de que em primeiro plano a demanda poderia ser atendida por um parecer consultivo, em segundo plano era de que existiam vínculos jurídicos entre o território em questão e o Reino de Marrocos, e por último, era de que existiam vínculos jurídicos entre esse território e a entidade da Mauritânia. 
A relação estabelecida entre o caso em questão e a autodeterminação dos povos, portanto, é compreendida através da livre escolha popular acerca das questões territoriais, e não como consequência particular de que a escolha possa ocasionar aos povos, tornando a Opinião Consultiva da Corte Internacional de Justiça (CIJ) no caso Sahara Ocidental ${ }^{62}$, uma referência para os instrumentos jurídicos internacionais, conforme se observa a seguir:

Os elementos e informações levados ao conhecimento da Corte demonstram a existência, ao tempo da colonização espanhola, de vínculos jurídicos de submissão entre o Sultão de Marrocos e algumas das tribos que viviam no território do Sahara Ocidental. Mostram igualmente a existência de direitos, incluindo alguns relacionados à terra, que constituíam vínculos jurídicos entre a entidade da Mauritânia, como entendeu a Corte e o território do Saara Ocidental. Por outro lado, a Corte concluiu que os elementos e informações levados ao seu conhecimento não estabeleceram a existência de nenhuma relação de soberania territorial entre o território do Sahara Ocidental e o Reino do Marrocos ou a entidade da Mauritânia. Desse modo, a Corte não encontrou vínculos jurídicos de natureza a modificar a aplicação da Resolução 1.514 (XV) da Assembleia Geral quanto à descolonização do Sahara Ocidental e, em particular, à aplicação do princípio da autodeterminação graças à expressão livre e espontânea vontade das populações do território ${ }^{63}$.

Dessa maneira, a formulação jurídica internacional da autodeterminação dos povos como princípio possui uma condição política que deve abranger as circunstâncias sob as quais um povo existe e desenvolve suas atividades políticas.

Andrés Sáenz de Santamaría64, afirma que "excepto en relación con la descolonización, los límites de la libre determinación en otros casos no se han definido completamente"65.

A manifestação mais notável da formulação jurídica internacional de autodeterminação, no entanto, é aquela cujo conteúdo enfoca no direito dos povos à autodeterminação como direito coletivo, que conduziu à atribuição de direitos a certas comunidades ou povos em que a subjetividade internacional é limitada .

${ }^{62}$ CORTE INTERNACIONAL DE JUSTIÇA (CIJ). Caso Sahara Ocidental. Disponível em: <http://www.icjcij.org/docket/index.php?p1=3\&p2=4\&code=sa\&case=61\&k=69>. Acesso em: 9 dez. 2016.

${ }^{63}$ PARECER CONSULTIVO DE 16 DE OUTUBRO DE 1975. Território do Sahara Ocidental. Opinião Consultiva. Disponível em: <http://centrodireitointernacional.com.br/wp-content/ uploads/2014/05/pareceresconsultivos_1974.pdf> Acesso em: 14 maio 2017.

${ }^{64}$ ANDRÉS SÁENZ DE SANTA MARÍA, Paz. La libre determinación de los pueblos en la nueva sociedad internacional. In: CARDONA LLORENS. Jorge (Coord.) Cursos euromediterráneos bancaja de derecho internacional. Pamplona, Aranzadi, 1997. v. 1, p. 123.

${ }^{65}$ Tradução: "exceto no que se refere à descolonização, os limites da autodeterminação em outros casos não estão totalmente definidos". 
A formulação da definição de autodeterminação que é obtida em seu conteúdo jurídico tem sido uma árdua tarefa à qual a doutrina não ofereceu respostas unânimes.

No início da década de 1950, ocorreu a formulação jurídica inicial da autodeterminação no contexto da descolonização.

Na década de 1960, no âmbito dos trabalhos para a Declaração sobre os Princípios do Direito Internacional, considerou-se que a formulação do princípio da igualdade de direitos e autodeterminação dos povos deveriam ser um direito inalienável dos povos para escolher livremente e em igualdade de condições seu próprio sistema político, econômico e social ${ }^{66}$.

Desde então, a autodeterminação tem sido objeto de várias definições e em sua formulação o direito à autodeterminação dos povos tem sido utilizado nos instrumentos internacionais no âmbito das Nações Unidas.

Nesse sentido, os Pareceres da Corte Internacional de Justiça (ClJ) contribuem grandiosamente para a evolução do Direito Internacional, tal como o acima mencionado.

Diferentemente das Sentenças em função da natureza consultiva, os Pareceres da Corte Internacional de Justiça (CIJ) são plenamente válidos e nenhum Estado ou qualquer sujeito de Direito Internacional de boa fé, pode desconhecê-los ou minimizá-los, para a garantia de direitos e o acesso à justiça.

Assim, a ClJ ao desenvolver sua função contensiosa está outorgada não apenas a dirimir as controvérsias suscitadas, mas também, habitada a dizer em qual o direito está pautado a referida lide.

E de maneira positiva os tribunais internacionais contemporâneos tem se expandido e contribuído para a consolidação da personalidade e capacidade jurídica do ser humano, considerado sujeito ativo nos tribunais internacionais de direitos humanos, bem como, sujeito passivo nos referidos tribunais de direito penal, consistindo assim, no relevante fundamento para a garantia do direito à autodeterminação dos povos.

No artigo 95 da Carta das Nações Unidas, ocorre a previsão da criação de novos tribunais internacionais, não havendo objeções nem na própria Carta

\footnotetext{
${ }^{66}$ EAGLETON, 1953. p. 88.
} 
mencionada e nem no Estatuto da CIJ, para o estabelecimento do referido monopólio que objetive a solução pacífica de controvérsias internacionais ${ }^{67}$.

Sendo assim, cada tribunal internacional possui sua jurisdição fundamentada em um tratado ou instrumento internacional distinto, com a aplicação de seu direito próprio, confirmando que o Direito Internacional é importante para resolver os mais distintos tipos de controvérsias internacioanais, tanto entre os Estados - interestatal quanto dentro deles - intraestatal, visando a realização da justiça e contribuindo para mitigar as inúmeras injustiças realizadas mundialmente em diversos âmbitos da sociedade moderna.

${ }^{67}$ TRINDADE, Antônio Augusto Cançado. Os Tribunais Internacionais e a realização da Justiça. 2. ed. ampl. Belo Horizonte: Del Rey, 2017. p. 260. 


\section{A AUTODETERMINAÇÃO E OS POVOS INDÍGENAS}

O estudo da autodeterminação exige três considerações relevantes para a compreensão da limitação do direito à autodeterminação com a aproximação do objeto de pesquisa, que é a consolidação de direitos na perspectiva de um processo democrático.

Figura 1 - Limites epistemológicos para a análise da autodeterminação.

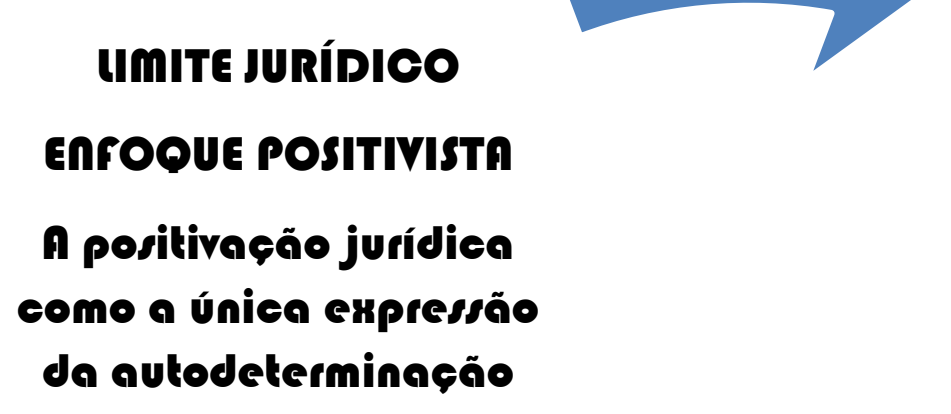

Umite JURÍDICO

EnFOQUE POSITIVISTA

A posilivação jurídica

da autodeterminação

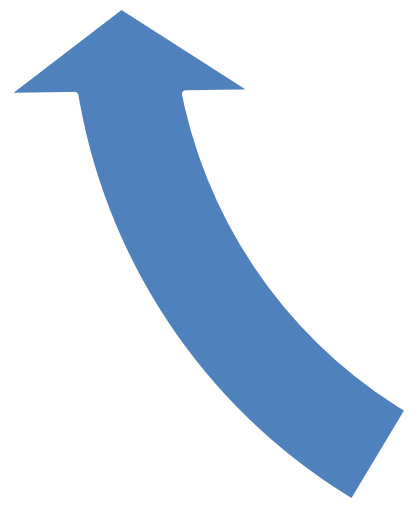

IImITE TEmPORA EnFOQUE COnTEmporâneo

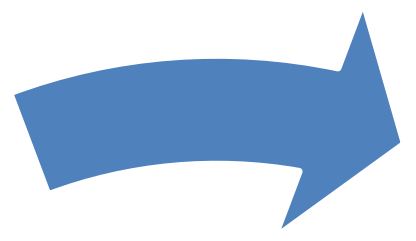

IImITE CONCEITUAI Enroove conceitunusta

O nascimento da autodeterminação entendido como 0 noscimento do conceito

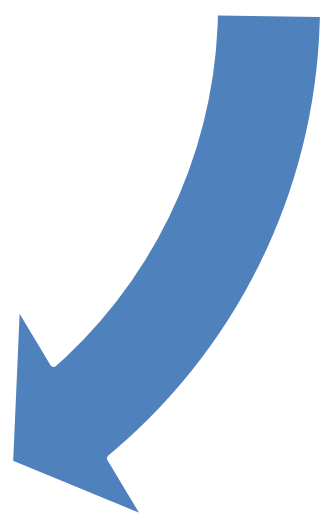

\section{A autodeterminaçño onolizoda erelusivamente na sua atual manifestação}


O primeiro aspecto a ser destacado é o excessivo enfoque jurídico-positivo (limite jurídico) para a construção do direito à autodeterminação como princípio do Direito Internacional e como direito subjetivo de um povo.

A positivação jurídica da autodeterminação é a consequência de um processo desenvolvido à margem do direito.

A impossibilidade de um marco jurídico para esse instrumento tem dificultado a construção de garantias aos povos no seu processo de desenvolvimento social.

O segundo aspecto refere-se é a abrangência conceitual (limite conceitual), pois as terminologias estabelecem rótulos para os significados de autodeterminação em cada momento histórico, os quais são utilizados.

No caso da autodeterminação, na maioria das análises, equipara-se o nascimento desse ideal com o momento histórico de sua conceitualização, o que de algum modo, acaba por dificultar sua análise ao longo da História.

O terceiro aspecto relaciona-se à falta de um histórico construtivista (limitação temporal), pois as análises de autodeterminação estão nitidamente vinculadas às manifestações relacionadas aos Estados Soberanos.

Nesse sentido, as lutas coloniais do século passado são atualmente aquelas pela consolidação de direitos fundamentais violados na sociedade contemporânea, pois a reivindicação da autodeterminação em relação ao Estado não é mais a expressão para a descolonização, mas para a afirmação de políticas sociais inclusivas, capazes de incorporarem atores sociais que estivem às margens do processo de desenvolvimento social, político e cultural do Estado, como as populações indígenas.

A autodeterminação envolve também questões políticas dos povos indígenas e seus direitos necessários para o desenvolvimento do controle político e administrativo de seus territórios e recursos naturais.

Nesse sentido, o direito à autodeterminação indígena pode ser analisado como o direito que esses povos têm de controlar suas instituições, seus territórios, seus recursos naturais, sua ordem social e suas culturas sem a interferência de dominação externa.

Autodeterminação consiste no direito de estabelecer sua relação com a sociedade dominante e com o Estado que o integra de maneira consensual para o atendimento dos interesses sociais. 
A relação existente entre a autodeterminação e os povos indígenas consiste nos princípios estabelecidos para a garantia de direitos sobre o território, a cultura e os recursos naturais, que constituem fundamentos relevantes para a construção do direito à autodeterminação dos povos indígenas.

A relevância desse direito é fundamental para garantir a autonomia das minorias étnicas como mecanismo de legitimação e organização de seus sistemas políticos próprios.

Esses fatores conduzem ao reconhecimento e à vigência dos sistemas sociais que essas populações indígenas constituem como agentes de desenvolvimento social no sistema jurídico democrático.

Assim sendo, o pluralismo jurídico é um relevante fundamento para o direito à diferença dos povos indígenas nos Estados e sistemas internacionais de proteção das minorias, pois o reconhecimento da justiça pressupõe a igualdade de tratamento como vetor fundamental para a consolidação de garantias.

\subsection{O significado do termo autodeterminação}

Os componentes essenciais para a operacionalização das dimensões evolutivas da autodeterminação ao longo da história compreendem:

a) A dimensão subjetiva através da comunidade: o ideal de autodeterminação tem sido afirmado por uma coletividade que possui laços de identidade racial, religiosa, nacional, étnica, cultural, linguística, geográfica ou política;

b) A dimensão objetiva por meio do autogoverno: ocorre quando uma comunidade tem buscado, em maior ou menor grau, de forma autônoma sua autogovernabilidade mediante sua identidade determinada pela coletividade;

c) A dimensão formal: é exercida pelo processo emancipatório como consequência das formas de autogoverno por parte da comunidade, materializandose através dos processos emancipatórios contra um terceiro que estiver impedindo o desenvolvimento dos objetivos da comunidade.

Nesse sentido, a autodeterminação é mais que uma realidade jurídica que abrange inúmeros pressupostos filosóficos e sociológicos inerentes aos direitos humanos, para a construção de diversos significados pluriétnicos e multiculturais.

Essa ampliação de entendimento jurídico na materialização da autodeterminação dos povos, além das estruturas jurídicas, conceituais e formais, 
conduz a sua relevância para a cristalização de direitos étnicos outrora não elencados no ordenamento positivo, sendo considerado de grande consideração para construção dos primeiros passos da jurisdição indígena.

Esses mecanismos de formação da autodeterminação em que a comunidade possui vínculos de identidade, especialmente étnicos, consistem em bases jurídicas importantes para garantia do direito dos povos e consolidação do direito à diferença, que objetive a construção de uma autogovernabilidade para os povos indígenas. 
Figura 2 - Evolução histórica do direito à Autodeterminação dos Povos.

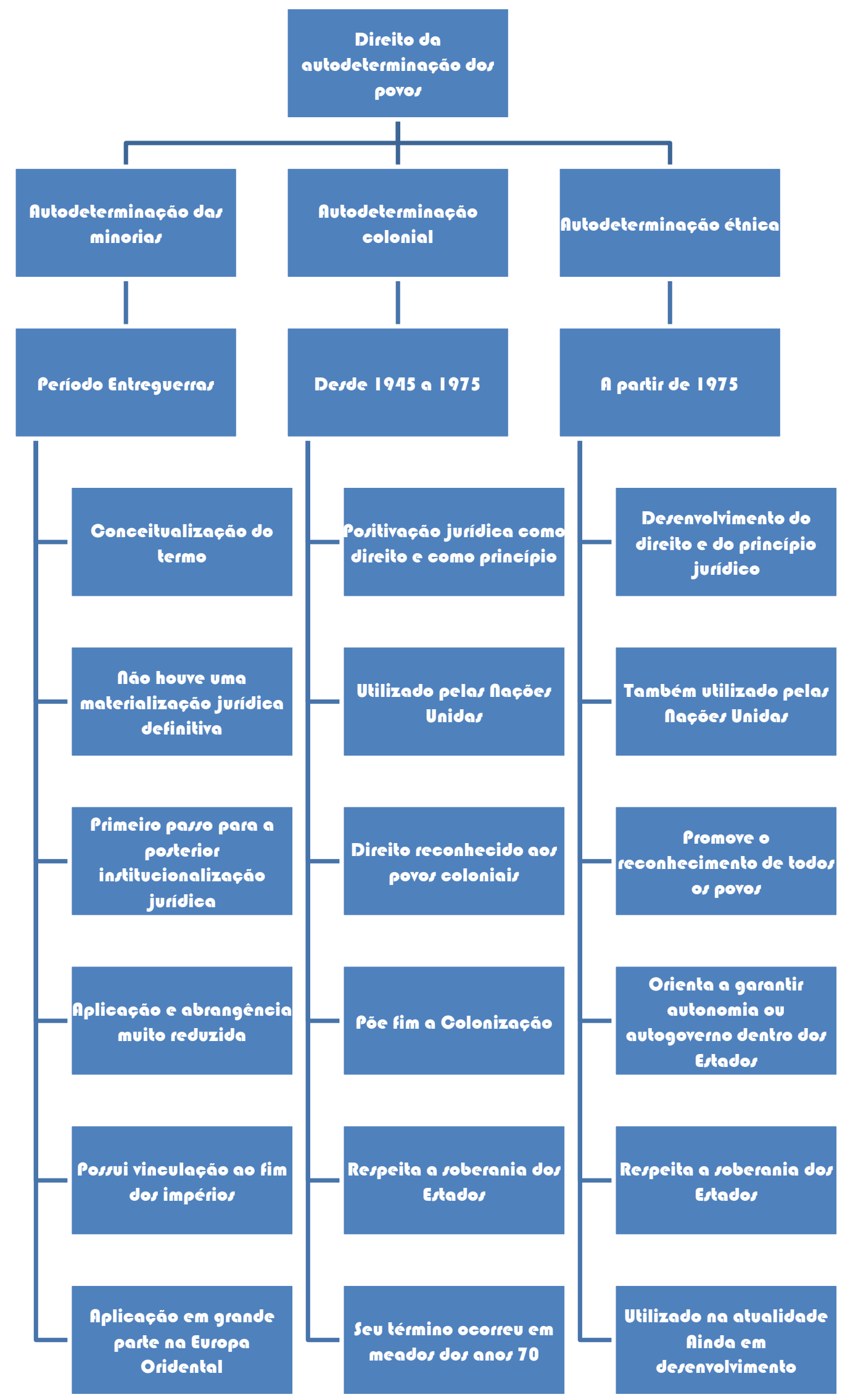

Fonte: Elaborada pela autora, 2017. 
Destarte, alguns significados possuem valores étnicos específicos que são imprescindíveis para o direito à autodeterminação dos povos indígenas, como: a cultura, o território, os recursos naturais, o direito à saúde dos povos isolados e, o consentimento livre, prévio e informado a todos os povos.

A autodeterminação tem se manifestado de diversas maneiras ao longo do processo histórico da humanidade. Sua concepção no Estado contemporâneo possui bases nas reivindicações sociais de desenvolvimento.

As três concepções contemporâneas de autodeterminação (minorias, colonial e étnica) abrigam o conceito de povo através dos preceitos de soberania.

Em seguida, essas concepções de autodeterminação desenvolvem a criação de uma instituição jurídica, que irá se conceitualizar e se transformar em princípio do direito que opera no âmbito internacional.

Dessa forma, uma coletividade unida por vínculo de identidade para reivindicar seu direito à autodeterminação é um fundamento relevante nas múltiplas formas de manifestação, que a sociedade tem construído ao longo de seu processo histórico para o fortalecimento de um movimento social, além dos ditames jurídicos.

Figura 3 - Evolução jurídica do direito à Autodeterminação dos Povos.

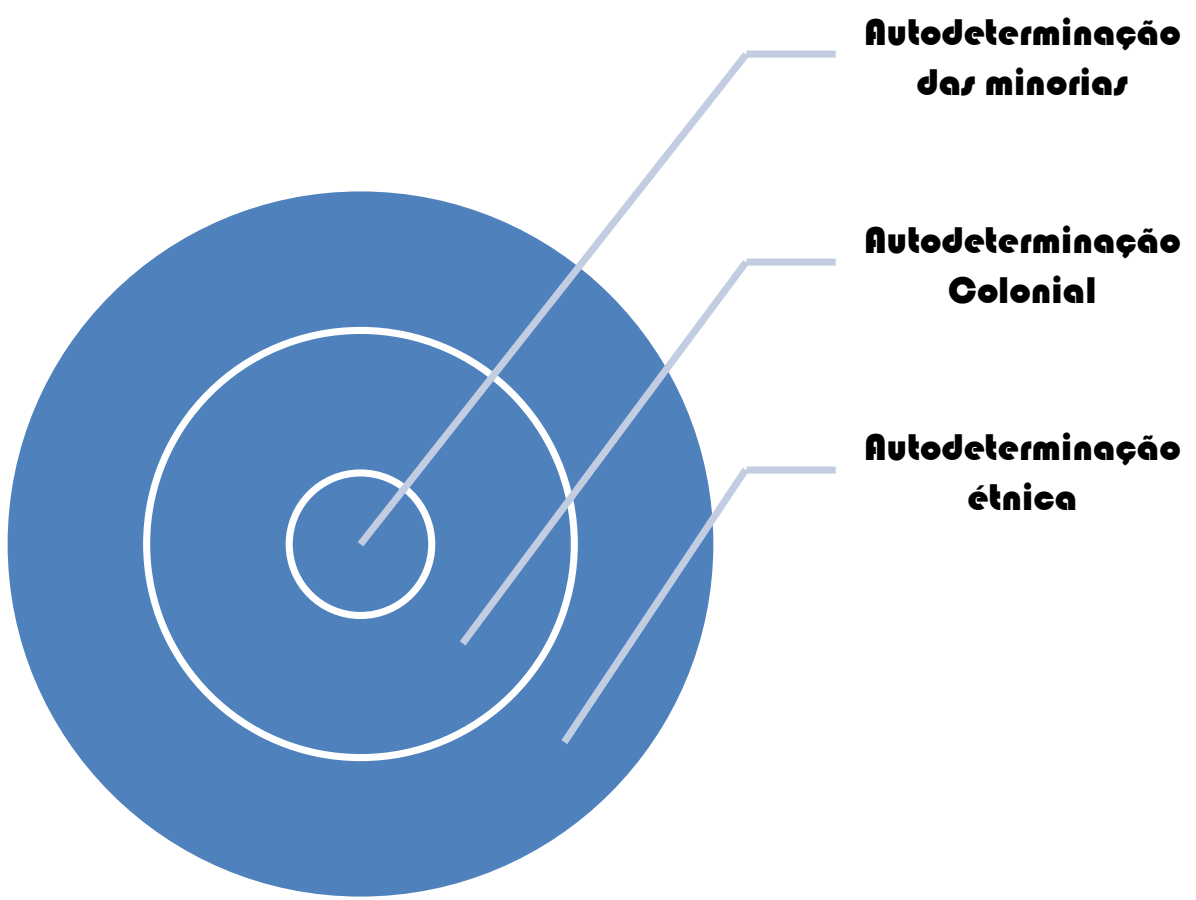

Fonte: Elaborada pela autora, 2017. 
Portanto, a obrigação de proteger a existência e a identidade das minorias étnicas como fator preponderante na consolidação da autodeterminação dos povos é uma ação positiva na a aplicação dos princípios da igualdade e não discriminação dos povos, sendo considerada um relevante fundamento para a construção dos direitos humanos internacionais na sociedade moderna.

\subsection{A autodeterminação na Declaração Unilateral de Independência no Kosovo}

A formulação jurídica da autodeterminação dos povos tem provocado mudanças em alguns âmbitos de regulação material do Direito Internacional. Em primeiro lugar, observa-se que a incorporação da autodeterminação aos Pactos Internacionais de direitos humanos, isso pressupõe um passo decisivo para a proclamação dos direitos coletivos das minorias, além de contribuir para a ampliação do direito de solidariedade ou de terceira geração.

Em segundo lugar, a formulação da autodeterminação dos povos tem influenciado significativamente nas normas relativas à delimitação internacional dos territórios.

E por último, o desenvolvimento progressivo das normas de Direito Internacional em relação à autodeterminação dos povos tem contribuído de maneira significativa para a evolução do direito internacional humanitário, conforme observase a seguir.

Com a dissolução da ex-lugoslávia e após a Sérvia não aceitar os acordos de Rambouillet, houve a eclosão do conflito no Kosovo, depois da sua supressão constitucional de autonomia em 1988 e da intensificação da repressão realizada pelo Presidente da República Sérvia, Milosevic, desde 1989.

Movimentos estudantis da Universidade de Prístina com ideais de independência e antissérvios desenvolveram um estado de emergência no Kosovo, ao mesmo tempo em que o nacionalismo sérvio intensificava sua expansão.

Nesse cenário, o líder Kosovar Ibrahim Rugova criou um aparato estatal no Kosovo. Havia o fomento separatista entre as comunidades sérvias e albanesas, além do estímulo ao retorno dos sérvios à região, visando a uma independência não violenta, apesar da generalização de uma política de discriminação, desnacionalização e repressão aos albaneses que habitavam no Kosovo. 
Consubstanciado no Capítulo VII da Carta das Nações Unidas, o Conselho de Segurança, por meio das Resoluções n. $1.160^{68}$ e n. 1.19969 , exigiu que as autoridades de Belgrado e as lideranças da Comunidade Albanesa no Kosovo iniciassem diálogos para a construção do seu status político, com o objetivo de finalizar as hostilidades crescentes na região e conseguir uma solução pacífica que visasse a restauração da paz e a estabilidade no Kosovo.

O Conselho de Segurança das Nações Unidas, pronunciou-se inicialmente sobre o conflito desenvolvido no Kosovo, afirmando que as autoridades de Belgrado deveriam oferecer à comunidade albanesa no Kosovo um processo político autêntico e que expressasse melhor condição jurídica para a região, capaz de promover maior autonomia e uma administração própria satisfatória à população do Kosovo.

Assim, as forças armadas da Organização do Tratado do Atlântico Norte OTAN fizeram que Milosevic aceitasse a realização de um acordo com a Organização para a Segurança e a Cooperação na Europa (OSCE), visando o desenvolvimento de uma missão de observação no Kosovo (Kosovo Verification Mission) para consolidar os preceitos estabelecidos nas Resoluções do Conselho de Segurança das Nações Unidas.

A persistência da atividade repressiva sérvia sobre a população do Kosovo, que buscava sua independência, levou à intervenção armada da OTAN sobre a lugoslávia mediante ataques aéreos. Essa ação da OTAN sem a prévia autorização do Conselho de Segurança resultou em relevantes questionamentos acerca de sua legalidade ${ }^{70}$, e as Nações Unidas, a fim de amenizar os conflitos e suspender 0 bombardeio da OTAN no território entre sérvios e a população do Kosovo, propôs um plano de paz. O objetivo era acabar com a violência e a repressão estabelecendo uma administração interina no Kosovo United Nations Interim Administration Mission in Kosovo (UNMK), para que a população Kosovar tivesse uma substancial autonomia decidida pelo Conselho de Segurança das Nações Unidas (CSNU), capaz de

\footnotetext{
${ }^{68}$ ORGANIZAÇÃO DAS NAÇÕES UNIDAS (ONU). Conselho de Segurança. Resolução n. 1.160, de 31 de março de 1998. Adaptada pelo Conselho de Segurança na sua $3.868^{\mathrm{a}}$ sessão. Disponível em: <http://legismactext.safp.gov.mo/2000/S2/2000_29/AVCE13_ANP.htm〉. Acesso em: 21 nov. 2016.

${ }^{69}$ ORGANIZAÇÃO DAS NAÇÕES UNIDAS (ONU). Conselho de Segurança. Resolução n. 1.199 de 23 de setembro de 1998. Disponível em: <http://www.un.org/en/sc/ documents/resolutions/ 1998. shtml>. Acesso em: 21 nov. 2016.

${ }^{70}$ MARTÍN, Araceli Mangas. Humanización, democracia y estado de derecho en el ordenamiento internacional. Madrid: Real Academia de Ciencias Morales y Políticas, 2014. Disponível em: <http://www.racmyp.es/R/racmyp/docs/discursos/D88.pdf>. Acesso em: 21 nov. 2016.
} 
estabelecer instituições provinciais de autogoverno para facilitar um processo político destinado a construir o futuro Estatuto do Kosovo, levando em consideração o Acordo de Rambouillet ${ }^{71}$.

O Estatuto do Kosovo deveria ser pautado nos valores da liberdade e da igualdade, os quais fundamentam o conteúdo jurídico da autodeterminação dos povos reconhecido principalmente pela proteção internacional dos direitos humanos.

Nesse sentido, as resoluções da ONU, as práticas internacionais e a doutrina internacionalista são compatíveis com o direito à autodeterminação dos povos, cujo exercício está pautado no processo de participação democrática, onde o povo possui o direito de expressar sua vontade e de determinar sua condição de desenvolvimento.

Assim, os valores de liberdade e igualdade que nortearam as decisões no Kosovo em sua formulação política para a consolidação do direito à autodeterminação dos povos, como princípio condutor do reconhecimento e da proteção internacional dos direitos humanos.

A liberdade é projetada sobre a livre expressão de vontade do povo contra a erradicação das formas de dominação colonial ou estrangeira, que de algum modo retardem o progresso dos povos ao desenvolvimento econômico, social e cultural.

Portanto, o reconhecimento internacional dos direitos individuais e coletivos relacionados às minorias, que vise a eliminação das graves e sistemáticas violações de direitos humanos, pode ser considerado um relevante fundamento para a consolidação do conteúdo jurídico da autodeterminação dos povos.

\subsubsection{Relevância da Declaração Unilateral de Independência no Kosovo}

A Declaração Unilateral de Independência no Kosovo evidencia uma especial atenção aos acontecimentos da contemporaneidade da ONU, para a administração internacional do território com as populações que habitam no espaço, revelando uma postura mais baseada nos direitos humanos em atendimento aos direitos dos povos, contando com a participação das organizações internacionais para a difusão dessa postura mais humanista de desenvolvimento mundial.

O ordenamento jurídico internacional contemporâneo, pautado no respeito ao direito dos povos ilustra que tanto o Estado quanto qualquer outra forma de

\footnotetext{
${ }^{71}$ Acordo celebrado na Alemanha no dia 5 de abril de 1999 pelos respectivos países: Alemanha, Grã-Bretanha, França e
} Estados Unidos, cujo objetivo era negociar de modo pacífico mecanismos multiétnicos e democráticos para o Kosovo. 
organização sócio-política, foram concebidos e passaram a existir para atender aos interesses da pessoa humana e não no processo inverso.

Nesse sentido, observa-se que o ser humano, a população e o povo constituem o mais importante elemento da condição de Estado.

De acordo com a administração internacional do território, nos sistemas de mandatos e de tutela existe um propósito comum entre eles que consiste na proteção dos povos e da população habitante sobre o território contra a exploração, abusos ou qualquer outra forma de crueldade, que afronte seus direitos outorgados pela Declaração Universal dos Direitos Humanos, visando assegurar a dignidade da pessoa humana enquanto princípio fundamental da humanidade.

Levando em consideração esses pressupostos ora mencionados, em 1992, a força de paz multinacional da United Nations Protection Force (UNPROFOR) finalizou as hostilidades por algum tempo no Kosovo, porém as forças sérvias ficaram em $\mathrm{Krajina}^{72}$ e na Eslovênia Oriental e continuaram ataques ocasionais, provocando desestabilização na região ${ }^{73}$.

A UNPROFOR foi estabelecida pela Resolução n. 743, de 21 de fevereiro de 1992, do CSNU, sendo modificada por diversas resoluções subsequentes em relação ao seu mandato e aos seus objetivos políticos e humanísticos de atuação para a região do Kosovo.

No que se refere à antiga lugoslávia, o CSNU, diante a crise ocasionada pela balcanização, votou diversas resoluções condenatórias aos sérvios, por exemplo, a Resolução n. 713, de 25 de setembro de 1991, em que o representante diplomático da lugoslávia na ONU foi convocado para participar das deliberações, mesmo sem direito a voto. Estabeleceu-se uma cooperação estratégica entre o Conselho de Segurança das Nações Unidas (CSNU) e a Conferência para a Segurança e Cooperação na Europa (CSCE), a qual foi transformada em OSCE após 1992, com o objetivo de relatar os casos de violações aos Direitos Humanos. Essa cooperação estratégica foi utilizada na crise do Kosovo no período de 1998 a 1999.

\footnotetext{
72 Entidade sérvia autoproclamada da Croácia em 1990, sendo que a história da República Sérvia de Krajina está diretamente vinculada ao processo de desintegração da Iugoslávia.

${ }^{73}$ BOURANTONIS, Dimitris; WIENER, Jarrod. The United Nations in the new world order: the world organization at fifty. Londres: Macmillan Press, 1995. p. 46.
} 
Por intermédio da Resolução n. 724, de 15 de dezembro de 1991, a Cooperação estratégica entre CSNU e a CSCE tornou-se mais intensa, dada a necessidade de enviar uma missão diplomática para verificar a conjuntura social, os aspectos humanitários e o desenvolvimento político da antiga lugoslávia.

O objetivo com essa cooperação estratégica era formar uma operação multinacional de paz para controlar a violência, por meio das sanções exclusivas do CSNU, que aprovou diversas resoluções condenando a antiga lugoslávia, instituindo o regime de sanções e as operações de paz iniciadas com a United Nations Protection Force, cujo objetivo era amenizar os crescentes conflitos étnicos e as tensões após o esfacelamento da lugoslávia ${ }^{74}$.

A guerra na Bósnia Herzegovina, em 1992, aprofundou a crise e somente por meio do Acordo de Dayton, nos Estados Unidos, foram negociadas as estratégias políticas para a Bósnia Herzegovina, visando à contenção da crise balcânica mediante o protagonismo de dois importantes diplomatas: o norte-americano Cyrus Vance e o ex-chanceler britânico David Owen ${ }^{75}$.

Nesses aspectos, o Conselho de Segurança das Nações Unidas (CSNU) solicitou à Cyrus Vance e David Owen que articulassem meios que possibilitassem uma saída razoável para a crise na antiga lugoslávia. Uma das medidas adotadas era dividir a Bósnia em territórios federados, sendo que três territórios estariam sob o controle dos croatas, três dos bósnios e três dos sérvios. Haveria, ainda, uma província com um governo misto com centralidade nas decisões externas ${ }^{76}$.

Infelizmente essa medida não obteve êxito, dada a instabilidade política e econômica que a crise causou, além da pouca confiança depositada nas partes negociantes do respectivo objetivo.

Dessa forma, a Resolução n. $770^{77}$ do Conselho de Segurança das Nações Unidas (CSNU), tem relevante significado, uma vez que autoriza os Estados a

\footnotetext{
${ }^{74}$ BOUTROS-GHALI. Consolidación de la paz y el desarrollo: memoria anual sobre la labor de la Organización entre los períodos de sesiones cuadragésimo octavo y cuadragésimo noveno. Nova Iorque: Departamento de Informações Públicas, 1994. p. 193-197.

75 CENTER FOR SECURITY POLICY. Clinton should back Bosnia in rejecting Vance-Owen plan. 1993. Disponível em: <http://www.centerforsecuritypolicy.org/1993/02/04/thanks-but-no-thanks-clinton-shouldback-bosnia-in-rejecting-vance-owen-peace-in-our-time-2//>. Acesso em: 8 nov. 2016.

${ }^{76}$ CASTRO, Thales. Conselho de Segurança da ONU: Unipolaridade, Consensos e Tendências. Curitiba: Juruá, 2007. p. 213.

${ }^{77}$ ORGANIZAÇÃO DAS NAÇÕES UNIDAS (ONU). Conselho de Segurança. Resolução n. 770, de 13 de agosto de 1992. Disponível em: <http://www.un.org/en/sc/documents/resolutions/1992.shtml>. Acesso em: 21 nov. 2016.
} 
utilizarem as Forças Armadas como fundamento para garantir a assistência humanitária.

Por intermédio da Resolução n. $776^{78}$ do Conselho de Segurança das Nações Unidas (CSNU), houve autorização da Força de Proteção das Nações Unidas $(\text { UNPROFOR })^{79}$ para recorrer ao uso das Forças Armadas no combate a graves violações de Direitos Humanos e da realização da limpeza étnica no Kosovo.

Dessa forma, o papel que as Forças Armadas sérvias e a ação política decisória que o governo central exerceu foram determinantes para que o CSNU determinasse embargar a venda de armas para a lugoslávia, haja vista que os sérvios foram acusados de realizar a faxina étnica no Kosovo, ocasionando a fuga de muitos albaneses para os Estados vizinhos, como Albânia e Macedônia ${ }^{80}$.

A situação ficou cada vez mais tensa na região quando a opinião pública foi mobilizada para que houvesse intervenções que garantissem os direitos da população kosovar e a redução da faxina étnica. Objetivando assegurar a paz e a segurança internacional, o Conselho de Segurança das Nações Unidas (CSNU), como órgão responsável para atuar em situações de conflitos armados internos, apresentou por meio do Secretário-Geral das Nações Unidas, Boutros Ghali, em 1992, o documento denominado "Um programa de paz e diplomacia preventiva, estabelecendo a manutenção da paz" ${ }^{81}$, visando abordar diversas questões relativas à proteção dos Direitos Humanos e das minorias presentes nos Estados.

No Kosovo, a Resolução n. 1.244 do CSNU $^{82}$ criou o UNMK, em 10 de junho de 1999, que, com a OSCE, exerceu papel muito importante na reconstrução do Kosovo para o processo de reconciliação nacional sob a responsabilidade do CSNU.

${ }^{78}$ ORGANIZAÇÃO DAS NAÇÕES UNIDAS (ONU). Conselho de Segurança. Resolução n. 776, de 13 de agosto de 1992. Disponível em: <http://www.un.org/en/sc/documents/resolutions/1992.shtml>. Acesso em: 21 nov. 2016.

79 FUERZA DE PROTECCIÓN DE LAS NACIONES UNIDAS (UNPROFOR). Disponível em: <http://www.un.org/es/peacekeeping/missions/past/unprofor/>. Acesso em: 21 nov. 2016.

${ }^{80}$ KALDOR, Mary. New and old wars: organized violence in a global era. 2. ed. California: Stanford University Press, 2007. p. 31-69.

${ }^{81}$ ORGANIZACIÓN DE LAS NACIONES UNIDAS (ONU). Asamblea General del Consejo de Seguridad. Agenda for peace: report of the Secretary-General Pursuant to the Statement Adopted by the Summit Meeting of the Security Council, 31 January 1992, A/47/227-S/24111, 17 June 1992. Disponível em: <www.un.org/es/comun/docs/?symbol=A/47/277>. Acesso em: 21 nov. 2016.

82 ORGANIZAÇÃO DAS NAÇÕES UNIDAS. Conselho de Segurança. Resolução n. 1.244, de 10 de junho de 1999. Disponível em: <https://documents-ddsny.un.org/doc/UNDOC/GEN/N99/172/89/PDF/N9917289.pdf?OpenElement>. Acesso em: 21 abr. 2017. A Resolução n. 1.244 do CSNU autorizou a presença civil e militar internacional em Kosovo, então parte da República Federal da Iugoslávia, colocando-a sob administração interina da ONU. Foi adotada em 10 de junho de 1999 (United Nations Bibliographic Information System). 
Sua função era realizar, no contexto jurídico, político e diplomático, o desenvolvimento e a manutenção da ordem mundial, conforme o capítulo VII da Carta das Nações Unidas, o qual dispõe sobre as possíveis ações do CSNU em caso de ameaças ou rupturas à paz e agressões, nomeando Estados-Membros para assegurar a segurança no sistema internacional ${ }^{83}$.

A questão da faxina étnica sobre as minorias albanesas no Kosovo desencadeou uma interação interinstitucional entre o OSCE, a CSNU e a OTAN, em que o entendimento do regionalismo para a Europa deveria ter papel importante no controle da crise no Kosovo. Não constituiria, sob nenhum aspecto, ilegalidade ou ilegitimidade a conduta por parte da atuação do CSNU e de nenhum de seus membros, à época, intervir para garantir os direitos da população Kosovar.

A Missão de Administração Provisória das Nações Unidas no Kosovo (UNMIK) deveria administrar civilmente o Kosovo na criação de instituições próprias, para seu autogoverno e transmissão progressiva de poder na região.

A administração internacional que se desenvolveu no Kosovo com o fim da guerra e a retirada da Sérvia da região tinha como encargo garantir a segurança e o desenvolvimento das instituições de autogoverno, além de desenvolver políticas para o retorno dos refugiados kosovares assegurando a estabilidade regional. No entanto, essa administração internacional não conseguiu conter a intensa limpeza étnica que os albaneses realizaram sobre os sérvios e outras minorias habitantes do Kosovo.

Em poucos anos, observou-se que a passividade administrativa estabelecida na região ampliou a população albanesa, reduzindo as minorias étnicas a uma pequena região denominada Mitrovica, localizada ao norte do Kosovo ${ }^{84}$.

O Comitê de Direitos Humanos das Nações Unidas que realiza a fiscalização do Pacto Internacional dos Direitos Civis e Políticos (PIDCP) emitiu, em 2006, um informe à Missão de Administração Provisória das Nações Unidas no Kosovo - UNMIK determinando que ela observasse os aspectos relacionados às questões dos direitos humanos na região: o direito à vida, a proibição do uso da tortura e tratamentos cruéis ou degradantes, bem como determinadas ações ilegítimas e ilegais praticadas pela

83 UNITED NATIONS BIBLIOGRAPHIC INFORMATION SYSTEM. Disponível em: <http://unbisnet. un.org/>. Acesso em: 8 nov. 2016.

${ }^{84}$ ANGOSTO, Ricardo. Las consecuencias humanitarias del conflicto do Kosovo-Metohija: documentos de segurança do Ministério da Defesa. Madrid, 2006. Disponível:<http://www.defensa. gob.es/ceseden/Galerias/destacados/publicaciones/docSegyDef/ficheros/002_FUTURO_DE_KOSOVOx_IM PLICACIONES_PARA_ESPANA.pdf>. Acesso em: 10 nov. 2016. 
polícia UNMIK e Kosovo Force (KFOR), que contribuíram para a limpeza étnica desencadeada no Kosovo.

Em 26 de março de 2007, Martti Ahtisaari entregou ao Secretário-Geral Ban Ki-moon um informativo sobre a solução realizada para o estatuto do Kosovo, o qual foi levado ao CSNU para aprovação. Nesse informativo, conhecido como Plano Ahtisaari, recomendava-se que a Independência do Kosovo sob supervisão internacional era considerada a única opção viável para uma economia e uma política estável na região.

Nesse sentido, a Resolução n. 1.244 do Conselho de Segurança das Nações Unidas (CSNU) ${ }^{85}$ ilustra um aspecto jurídico importante para a autodeterminação interna no Kosovo, mediante um autogoverno de ampla autonomia para as minorias étnicas residentes na região, que pode servir de exemplo para outras minorias étnicas na sociedade moderna que possuam seus direitos fundamentais violados e seus direitos culturais desrespeitados.

A independência do Kosovo promoveria a construção de instituições democráticas devidamente responsáveis pelos seus atos, fundamento importante para a garantia do Estado de Direito e efetiva proteção das minorias, de modo a estabelecer uma condição sustentável entre o Kosovo e a Sérvia.

Segundo o informe Ahtisaari, a situação dos sérvios e dos kosovares eram

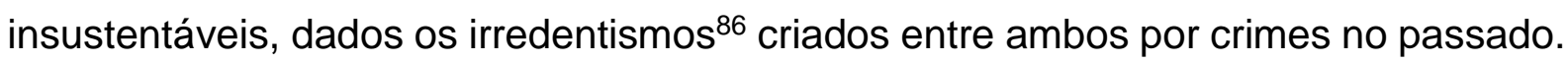
Essa complexa situação, provocaria constantes instabilidades no Kosovo, desencadeando novos conflitos armados, em que as minorias étnicas eram as mais atingidas na região.

A inviabilidade da autonomia e de um autogoverno no Kosovo ilustra, também, a impossibilidade na resolução de um conflito de autodeterminação interna, segundo - Ahtisaari. A solução para o respectivo conflito seria a secessão ou "Doutrina Ahtisaari”, porque ela promoveria uma abertura para uma configuração jurídica internacional em relação ao princípio da autodeterminação dos povos, bem como possuiria reflexos positivos na consolidação da responsabilidade de proteger.

${ }^{85}$ ORGANIZAÇÃO DAS NAÇÕES UNIDAS (ONU). Conselho de Segurança. Resolução n. 1.244, de 10 de junho de 1999. Disponível em: <https://documents-dds-ny.un.org/doc/UNDOC/GEN/N99/ 172/89/PDF/N9917289.pdf?OpenElement>. Acesso em: 21 abr. 2017.

${ }^{86} \mathrm{O}$ irredentismo se produz quando uma comunidade reivindica a separação de parte de um território do Estado sobre o qual se assenta, com a finalidade de integrar-se ao território de outro Estado soberano e independente no qual a população compartilha características étnicas, linguísticas ou religiosas. 
O informe Ahtisaari trazia uma proposta de acordo para o Estatuto do Kosovo evidenciando detalhadamente os procedimentos que deveriam ser realizados na consolidação da Declaração Unilateral de Independência no Kosovo.

Nesse sentido, a proposta Ahtisaari87 desenvolveria alguns ditames internacionais na regulamentação do processo de independência para o Kosovo, até que este fosse capaz de desenvolver suas próprias atividades e exercer seu autogoverno.

Dessa forma, o Kosovo declarou, unilateralmente, sua independência em 17 de fevereiro de 2008, sendo considerado um ato nitidamente contrário à Resolução n. 1.244 do Conselho de Segurança das Nações Unidas (CSNU), que outorgava um direito de autodeterminação interna para o Kosovo, respeitando a unidade territorial da Sérvia.

Gradativamente, o princípio da autodeterminação interna começava a sofrer mudanças para a construção do direito de secessão como mecanismo de permitir uma separação unilateral de determinado território quando ocorressem graves crimes que violassem os direitos humanos.

A proclamação da Declaração Unilateral de Independência do Kosovo foi realizada por seu parlamento, já que se admitia o direito de autodeterminação de um povo por meio de um ato legislativo, sem que, necessariamente, toda a população se pronunciasse de forma individualizada sob a influência dos países ocidentais.

Dessa maneira, a utilização do princípio da autodeterminação dos povos como fundamento para a expansão e consolidação do direito de secessão, nos casos em que ocorressem violação de direitos de um povo, rompia com as inquestionáveis cláusulas de salvaguarda e da unidade territorial, nos termos das Resoluções n. $2.625^{88}$ e $1.514^{89}$ da Assembleia Geral das Nações Unidas, ampliando no cenário internacional a construção do direito dos povos.

Atualmente, 110 dos 193 Estados-Membros das Nações Unidas têm reconhecido a Declaração Unilateral de Independência do Kosovo, sendo que 23 dos

\footnotetext{
${ }^{87}$ A proposta Ahtisaari evidencia um esquema normativo e institucional detalhado para a Declaração Unilateral de Independência para o Kosovo, regulando seus dispositivos constitucionais, elaborando a categorização de direitos fundamentais para a região e instituição dos três poderes para administração sóciopolítica dos kosovares, além da demarcação dos municípios, das línguas oficiais, da função pública, do controle financeiro em relação as dívidas externas e regulamentando a comissão constituinte para a consolidação da Constituição do Kosovo.

${ }^{88}$ ORGANIZAÇÃO DAS NAÇÕES UNIDAS, 1970.

${ }^{89}$ ORGANIZAÇÃO DAS NAÇÕES UNIDAS, 1960.
} 
27 países da União Europeia o reconhecem, fazendo com os Estados estejam a favor da respectiva Declaração Unilateral de Independência no Kosovo, conforme a Opinião Consultiva da Corte Internacional de Justiça (CIJ) de 22 de julho de $2010^{90}$.

A Declaração Unilateral de Independência no Kosovo não violou nenhuma norma de Direito Internacional Geral, porém a habilitação da secessão no direito à autodeterminação foi um dos aspectos que a ClJ, evitou realizar um pronunciamento expresso na Opinião Consultiva de 22 de julho de $2010^{91}$, por entender que não tinha relação imediata com o questionamento suscitado, conforme se observa a seguir:

Los temas referentes a la extensión del derecho de autodeterminación y la existencia de un derecho a la 'secesión remedio' están más allá del alcance de la cuestión planteada por la Asamblea Genera ${ }^{92}$.

Assim, a ClJ evitava se pronunciar sobre a existência de um direito de secessão que havia mudado o conteúdo da autodeterminação, permitindo a utilização da secessão em casos de graves violações de direitos humanos.

Na Opinião Consultiva, afirma-se que o direito de secessão na Declaração Unilateral de Independência do Kosovo não viola preceitos do Direito Internacional e possibilita a efetiva materialidade para o seu exercício, a fim de assegurar os direitos fundamentais violados contra um povo territorialmente determinado.

O não pronunciamento do direito de secessão pela ClJ como base jurídica habitual e a respectiva materialidade do direito para a ampliação do direito à autodeterminação dos povos serão realizados de acordo com a prática dos Estados em seu regular exercício e a opinio juris ${ }^{93}$, para a institucionalização e a consolidação do direito de secessão.

90 CORTE INTERNACIONAL DE JUSTIÇA (CIJ). Opinião Consultiva de 22 de julho de 2010. Ilustra a conformidade do Direito Internacional na Declaração Unilateral de Independência no Kosovo por suas instituições provisórias do autogoverno. Disponível em: 〈http://www.mfa-ks.net/?page=2,1〉. Acesso em: 11 nov. 2016.

91 ORGANIZAÇÃO DAS NAÇÕES UNIDAS (ONU). Assembleia Geral. La opinión Consultiva de la Corte Internacional de Justicia de 22 de julio de 2010 sobre la conformidad con el Derecho internacional de la declaración unilateral de independencia de Kosovo. Revista Española de Derecho Internacional v. 43, n. 1, p. 149-197. 2011. Disponível em: <http://bibliotecaculturajuridica. com /biblioteca/arxius/PDF/REDI_Vol._LXIII_1_2011//07_Opinion_Consultiva_digital.pdf>.Acesso em: 12 nov. 2016.

92 Tradução: Os temas referentes a extensão do direito de autodeterminação e a existência do direito de secessão, estão além do alcance da questão levantada pela Assembleia Geral.

93 "É considerado, no direito internacional consuetudinário, o elemento necessário para estabelecer um costume juridicamente vinculativo, denotando uma obrigação subjetiva e um sentido em nome de um Estado que está vinculado à lei em questão, conforme o Estatuto da CIJ: artigo 38, no qual o costume a ser aplicado deve ser "aceito como lei". 
Dessa forma, a Opinião Consultiva da Corte Internacional de Justiça (CIJ) de 22 de julho de 2010, acerca da Declaração de Independência do Kosovo atende aos princípios do Direito Internacional no marco de direitos das Nações Unidas e em relação a finalidade humanista do Estado, pois observa-se a superação do paradigma até então estabelecido, como sendo estritamente interestatal no Direito Internacional Contemporâneo.

Esse atendimento ao direito dos povos em relação ao território como garantia da dignidade humana, baseado nos pressupostos dos direitos humanos é fundamental para o avanço do ordenamento jurídico internacional, sobretudo na atenção, proteção e tutela pela comunidade internacional para o desenvolvimento social.

As graves violações de direitos humanos realizadas contra os povos tem integrado nos últimos anos o Direito Internacional contemporâneo, através do estabelecimento de mecanismos para a proteção e prevenção destes direitos.

Nesse sentido, os instrumentos internacionais de proteção dos povos e de graves violações de direitos tem desenvolvido recentemente, estreitas relações com o direito à autodeterminação dos povos.

3.2.2 Autodeterminação e igualdade de direitos como norma fundamental para o desenvolvimento do Estado Democrático de Direito

A autodeterminação dos povos e o princípio da igualdade de direitos constituem partes complementares de uma única norma fundamental para o desenvolvimento de relações amistosas e o fortalecimento da paz mundial.

Nesse sentido, o princípio da autodeterminação dos povos possui duas grandes correntes fundamentais para sua efetiva compreensão histórica e construção de Direitos Humanos.

A primeira concentra-se nos órgãos políticos, principalmente na Assembleia Geral da ONU, cuja finalidade é o estabelecimento da independência colonial. Nesse entendimento, ocorre o predomínio do elemento político sobre o elemento jurídico de aplicação do princípio da autodeterminação dos povos, levando ao desenvolvimento da Declaração sobre a Independência Colonial de 14 de dezembro de $1960^{94}$.

${ }^{94}$ ORGANIZAÇÃO DAS NAÇÕES UNIDAS (ONU). Resolução 1514 (XV) da Assembleia Geral de 14 de dezembro de 1960. Declaração sobre a independência colonial de 14 de dezembro de 1960. Disponível em: <http://www.dhnet.org.br/direitos/sip/onu/spovos/dec60.htm>. Acesso em: $1^{\circ}$ nov. 2016. 
A segunda corrente manifestou-se no âmbito da preparação dos Pactos de Direitos Humanos para elaboração de uma Carta Internacional de Direitos na qual houvesse o predomínio do elemento jurídico sobre o político, como resultado dos Pactos Internacionais de 1966, de direitos civis e políticos ${ }^{95}$, bem como de direitos econômicos, sociais e culturais, os quais possuem em comum 0 artigo $1^{\circ}$, que se refere aos direitos de autodeterminação dos povos:

1. Todos os povos têm direito a autodeterminação. Em virtude desse direito, determinam livremente seu estatuto político e asseguram livremente seu desenvolvimento econômico, social e cultural.

2. Para a consecução de seus objetivos, todos os povos podem dispor livremente de suas riquezas e de seus recursos naturais, sem prejuízo das obrigações decorrentes da cooperação econômica internacional, baseada no princípio do proveito mútuo, e do Direito Internacional. Em caso algum, poderá um povo ser privado de seus próprios meios de subsistência.

3. Os Estados Partes do presente Pacto, inclusive aqueles que tenham a responsabilidade de administrar territórios não-autônomos e territórios sob tutela, deverão promover o exercício do direito à autodeterminação e respeitar esse direito, em conformidade com as disposições da Carta das Nações Unidas.

Ainda que a autodeterminação tenha sido amplamente aplicada no processo de descolonização como direito dos povos coloniais à Independência, na atualidade, não existe um consenso em relação ao seu alcance e à sua aplicabilidade. Isso faz que esse princípio do Direito Internacional ainda esteja sendo consolidado com a expansão dos direitos humanos.

A evolução dos direitos humanos no âmbito internacional teve grande interferência na consolidação do direito à autodeterminação dos povos, mediante maior atenção e proteção do Direito Internacional para os casos que realizem a violação de direitos humanos, porque a nova concepção para o reconhecimento de direitos dos povos, após o período colonial, é assegurada pelo Pacto Internacional de Direitos Civis e Políticos, bem como pelo Pacto Internacional de Direitos Econômicos, Sociais e Culturais, ambos de 1966.

\footnotetext{
${ }^{95}$ ORGANIZAÇÃO DAS NAÇÕES UNIDAS. Assembleia Geral. Pacto internacional de direitos civis e políticos. 1976. Disponível em: <http://www.refugiados.net/cid_virtual_bkup/asilo2/2pidcp.html>. Acesso em: 22 abr. 2017.
} 
Nesses pactos reconhecia-se que todos os povos eram titulares de direito, conforme pode ser observado na Resolução n. 2.625, da Assembleia Geral das Nações Unidas, de 24 de outubro de 1970'96:

By virtue of the principle of equal rights and self-determination of peoples enshrined in the Charter of the United Nations, all peoples have the right freely to determine without external interference, their political status and to pursue their economic, social and cultural development and every State has the duty to respect this right in accordance with the provisions of the Charter $^{97}$.

As constantes violações de direitos cometidas contra as populações em diversos processos históricos mundiais têm desenvolvido no Direito Internacional interesses significativos, uma vez que os mecanismos de prevenção e coerção têm ampliado os debates internacionais para os instrumentos de proteção aos povos ou minorias étnicas vítimas de graves violações de direitos humanos que afetam o efetivo exercício do direito de autodeterminação dos povos.

A Declaração sobre os Princípios de Direito Internacional referente às Relações de Amizade e Cooperação entre os Estados - Resolução n. 2.625, de 24 de outubro de 1970 (XXV) da Assembleia Geral das Nações Unidas - contribuiu para o progressivo desenvolvimento dos princípios de Direito Internacional, como propósito das Nações Unidas por meio da Conferência de São Francisco, no artigo $1^{\circ} \S 2^{\circ 998}$ :

Desenvolver relações amistosas entre as nações, baseadas no respeito ao princípio de igualdade de direitos e de autodeterminação dos povos, e tomar outras medidas apropriadas ao fortalecimento da paz universal.

Com base nos propósitos das Nações Unidas, a sujeição dos povos à subjugação, à dominação e à exploração estrangeira constituía um dos maiores

96 ORGANIZAÇÃO DAS NAÇÕES UNIDAS (ONU). Assembleia Geral. Resolução n. 2.625 (XXV), de 24 de outubro de 1970. Declaração sobre os princípios de direito internacional referente às relações de amizade e cooperação entre os Estados de acordo com a Carta das Nações Unidas. Disponível em: < http://www.un.org/documents/ga/res/25/ares25.htm> . Acesso em: 22 abr. 2017.

97 Tradução: Em virtude do princípio da igualdade de direitos e da autodeterminação dos povos consagrado na Carta das Nações Unidas, todos os povos têm o direito de determinar livremente, sem interferência externa, o seu estatuto político e de prosseguir com o seu desenvolvimento econômico, social e cultural, e o Estado tem o dever de respeitar este direito de acordo com as disposições da Carta das Nações Unidas.

98 ORGANIZAÇÃO DAS NAÇÕES UNIDAS. Carta das Nações Unidas, de 1945. Disponível:<https://nacoesunidas.org/carta/cap1/>. Acesso: 22 abr. 2017. 
obstáculos para o crescimento da paz mundial, da segurança internacional de um povo e da igualdade de direitos para a consolidação da autodeterminação, aspectos importantes para o Direito Internacional contemporâneo, uma vez que fomentam as relações de amizade entre os Estados, respeitando-Ihes a soberania.

Levando em consideração os pressupostos estabelecidos na Resolução $\mathrm{n}$. 2.625 da Assembleia Geral das Nações Unidas, observa-se que a igualdade de direitos e a autodeterminação dos povos, em 1945, eram consideradas apenas princípios instrumentais de fomento às Relações de Amizade entre os Estados, porém, a partir de 1970, passaram a ser princípios básicos e estruturantes do Direito Internacional Contemporâneo.

Os princípios de Direito Internacional, à luz da Declaração, podem ser analisados em quatro aspectos:

1) Quem são os titulares do princípio de autodeterminação dos povos?

2) Quais as condições jurídicas do território para o exercício desse direito?

3) Qual é o conteúdo do princípio de autodeterminação dos povos?

4) E qual a aplicação deles?

De acordo com o artigo $1^{\circ}$ do Pacto Internacional dos Direitos Civis e Políticos (PIDCP) e do Pacto Internacional dos Direitos Econômicos, Sociais e Culturais (PIDESC), de 1966, a formulação do direito de autodeterminação possui caráter universal, haja vista que todos os povos são titulares ao exercício do princípio de autodeterminação.

As condições jurídicas do território são fundamentos importantes para que os povos assentados em territórios dependentes possam exercer livremente e sem ingerências seu direito à autodeterminação.

Dessa forma, a Resolução n. 2.625 da Assembleia Geral das Nações Unidas ${ }^{99}$ estipulou que a condição jurídica existirá tanto para os povos coloniais como para aqueles habitantes em território não autônomo, a fim de que o exercício da autodeterminação dos povos seja realizado de acordo com a Carta das Nações Unidas.

\footnotetext{
${ }^{99}$ ORGANIZAÇÃO DAS NAÇÕES UNIDAS (ONU). Assembleia Geral. Resolução n. 2.625 (XXV), de 24 de outubro de 1970. Declaração sobre os princípios de direito internacional referente às relações de amizade e cooperação entre os Estados de acordo com a Carta das Nações Unidas. Disponível em: < http://www.un.org/documents/ga/res/25/ares25.htm> . Acesso em: 22 abr. 2017.
} 
A condição jurídica do território dependerá de como está sendo exercido o direito de autodeterminação pelo povo territorialmente assentado e os Estados são obrigados a respeitar o direito de autodeterminação dos povos, promovendo a efetividade dos direitos humanos e assegurando as liberdades fundamentais de todos os cidadãos, conforme os preceitos da Carta das Nações Unidas.

Nesse sentido, a construção do direito de autodeterminação dos povos, formulado pela Resolução n. 2.625 da Assembleia Geral das Nações Unidas, possui o mesmo enunciado e conteúdo da Declaração sobre a Concessão de Independência dos Países e Povos Coloniais, além dos aspectos descritos nos Pactos Internacionais de Direitos Humanos de como estimular o desenvolvimento econômico, social e cultural de um povo à autodeterminação para a consolidação de sua condição política.

O princípio da igualdade de direitos e da autodeterminação dos povos, com base na Resolução n. 2.625 da Assembleia Geral das Nações Unidas, objetiva fomentar as Relações de Amizade e de Cooperação entre os Estados para que os aspectos eminentes do colonialismo sejam gradativamente substituídos pelos ditames democráticos norteadores do Estado de Direito.

Na Resolução n. $2.625^{100}$ descreve-se como o povo pode exercer o direito à autodeterminação:

1) Através do estabelecimento de um Estado Soberano e Independente;

2) Com a livre associação ou integração de um Estado Independente;

3) Ou através da aquisição de qualquer outra condição política livremente decidida por um povo.

Por outro lado, a Resolução n. 2.625 da Assembleia Geral das Nações Unidas estabelece a proibição de ameaça ou uso da força, para garantia da igualdade soberana e integridade territorial dos Estados.

De acordo com a Declaração, os povos têm o direito de oferecer resistência às medidas de forças utilizadas pelo Estado quando existirem violações de seus direitos fundamentais que comprometam o efetivo exercício dos direitos humanos, conforme a Carta das Nações Unidas.

Dessa maneira, os Estados se abstêm de utilizar medidas coercitivas que, de qualquer modo, limitem o efetivo exercício do direito de autodeterminação, a liberdade e a independência do povo.

${ }^{100}$ ORGANIZAÇÃO DAS NAÇÕES UNIDAS, 1970. 
Assim, os Estados devem assegurar a igualdade de direitos para a construção da autodeterminação dos povos, de modo que a representatividade popular assegure esses direitos, independentemente de raça, cor ou religião, já que a submissão dos povos a qualquer subjugação, dominação ou exploração estrangeira constitui uma denegação aos direitos humanos e preceitos estabelecidos pela Carta das Nações Unidas.

No cenário internacional, a independência unilateral de Bangladesh foi um caso que impulsionou grandes manifestações na luta contra as graves violações aos direitos humanos de um povo territorialmente determinado.

Esse caso desenvolveu um precedente que possibilitará a aceitação do direito de secessão em situações excepcionais, como forma de garantir e proteger os direitos dos povos.

Com a internacionalização dos Direitos Humanos ${ }^{101}$, observa-se o progressivo crescimento das normas de proteção do ser humano como sujeito de direito das normas internacionais de maneira autônoma, além dos direitos que lhe são assegurados pela soberania dos Estados.

O Direito Internacional visa tutelar direitos fundamentais dos povos, sejam eles nacionais, sejam religiosos, étnicos ou raciais, a fim de assegurar o direito à autodeterminação dos povos no cenário internacional.

No âmbito internacional, os povos bósnios ${ }^{102}$, tutsis ${ }^{103}$, maias ${ }^{104}$, albanokosovares são objetos de proteção judicial internacional, uma vez que ilustram, no âmbito internacional, que sofreram graves violações de direitos humanos e perseguições sistemáticas em desatendimento ao princípio da autodeterminação dos povos.

A relação estabelecida entre a autodeterminação e a proteção dos povos no Direito Internacional será realizada da seguinte maneira:

1) Por meio das violações de direito à autodeterminação interna, mediante o reconhecimento de sua autonomia, observado pela cláusula de legitimidade ${ }^{105}$.

101 VILLALPANDO, Waldo. Los derechos humanos: la conciencia moral del siglo XX. In: De los derechos humanos al derecho internacional penal. Buenos Aires: Abeledo-Perrot, 2000. p. 83.

102 Bósnio é o povo eslavo que habita a região do Leste Europeu.

103 Os tútsis são grupos étnicos de Ruanda e do Burundi, como também das regiões adjacentes do Congo, da Uganda e da Tanzânia.

${ }^{104}$ Os povos maias formam populações consideráveis e mantêm um conjunto distinto de tradições e crenças, que são o resultado da fusão das ideologias pré-colombianas.

105 Cláusula de legitimidade que proíbe questionar o princípio da soberania nacional e integridade territorial. 
2) $\mathrm{Na}$ ruptura da unidade territorial por intermédio da cláusula de salvaguarda ${ }^{106}$, como a única solução para garantir a proteção de uma minoria e conseguir a segurança de um grupo étnico.

3) Por meio das sistemáticas agressões contra uma minoria étnica, a qual possui assegurado seu direito à autodeterminação em relação ao Estado soberano que realizou essas violações de direitos.

No caso do Kosovo, a concentração regional desses crimes reforça a exigência da autodeterminação dos povos como a materialização do direito de secessão ${ }^{107}$ e como mecanismo de cessar as graves violações de direitos humanos sobre as minorias étnicas existente no território.

Nesse contexto, Kosovo não era mais que uma parte do território sérvio e apresentava um problema particular, com sua maioria albanesa em uma terra considerada o berço do Reino Sérvio ${ }^{108}$.

Em 1929, surgiu na lugoslávia um sistema político ditatorial conduzido por Alejandro I, que, para recuperar o Kosovo, utilizou uma política de agressividade enviando colonos e expulsando albaneses da região.

Com a eclosão da segunda Guerra Mundial, a lugoslávia foi invadida pelo III Reich alemão em 1941, sendo o Kosovo entregue em grande parte à Albânia, país que colaborava com o regime fascista.

Durante muitos anos, a colaboração dos albano-kosovares para as potências do eixo ocorreu de maneira integral, gerando intensa perseguição, deportação e expulsões de sérvios.

Em 1974, com a aprovação da nova Constituição da lugoslávia, houve a configuração de uma província autônoma, tanto no Kosovo quanto na Província de Voivodina, reconhecendo o direito de representação e condições de participação no

${ }^{106}$ Cláusula de salvaguarda reconhece a necessidade de respeitar em todo caso a unidade nacional e integridade territorial.

${ }^{107}$ A indefinição jurídica que se criou em torno da independência do Kosovo em relação à secessão como forma de materializar a autodeterminação ocasionou uma opinião consultiva da Corte Internacional de Justiça para um consenso sobre esse instituto fundamental para o Direito Internacional. Nesse sentido, a Assembleia Geral da ONU manifestou-se por meio da Resolução n. 63/3, de 8 de outubro de 2008, na qual se afirmava que a declaração unilateral pelas instituições provincianas de autogoverno no Kosovo estava em conformidade com o Direito Internacional. ORGANIZACIÓN NACIONES UNIDAS (ONU). Asamblea General. Resoluciones. Nova York, 8 de outubro de 2008. Disponível em: <http://www.un.org/es/ga/63/resolutions.shtml>. Acesso em: 8 dez. 2016.

${ }^{108}$ GARCIA, Fernando; JIMÉNEZ, Inmaculada (Coord.). Informe sobre el conflicto y la guerra do Kosovo. Madrid: Ediciones del Oriente y del Mediterráneo, 1999. p. 29-31. 
Estado federativo semelhante ao restante das outras Repúblicas como Eslovênia, Bósnia-Herzegovina, Croácia, Sérvia, Montenegro e Macedônia.

O Kosovo possuiria sua própria Constituição para usufruir um autogoverno e participar nas estruturas políticas, mediante o exercício da autodeterminação interna dos povos albano-kosovares, a fim de constituírem uma República dentro da lugoslávia e possuírem o reconhecimento de sua autonomia e autogoverno.

A secessão unilateral no Kosovo ocorreu em 23 de março de 1989, mediante a supressão à autonomia kosovar de maneira unilateral pela Sérvia. Essa prática era uma violação à autodeterminação interna do povo albano-kosovar, que havia conquistado o reconhecimento de seus direitos como consequência de seu regime de província autônoma por intermédio da Constituição da lugoslávia de 1974.

A simples violação da autonomia do Kosovo não foi motivo suficiente para que a comunidade internacional reconhecesse o direito de sua autodeterminação por meio da Declaração Unilateral de Independência, mas as graves violações de direitos humanos contra essa população.

Nesse cenário internacional, os parlamentares albano-kosovares aprovaram, em 7 de setembro de 1990, em Kaçanik ${ }^{109}$, a República do Kosovo, com base na Constituição da lugoslávia.

Em 1991, após a dissolução da lugoslávia, ocorreu a independência da República de Kosovo ${ }^{110}$, sem efetivo apoio da comunidade internacional, que contestara a observância dos pressupostos da soberania no referido processo de Declaração Unilateral de Independência, a qual contrariava o princípio da autodeterminação em sua dimensão interna, já que não ocorreu uma consulta popular para a proclamação do respectivo momento histórico.

Depois da Declaração Unilateral de Independência do Kosovo, pode-se afirmar que ele se constituiu em Estado, conforme o reconhecimento da Convenção de Montevidéu de $1933^{111}$, ao ilustrar que "a existência política do Estado é independente de seu reconhecimento por outros Estados", haja vista que a

\footnotetext{
${ }^{109}$ Cidade ao sul do Kosovo localizada no Distrito de Ferizaj. O município ocupa uma área de $211 \mathrm{~km}^{2}$, incluindo a cidade de Kaçanik, além de possuir 31 aldeias.

110 CLARK, Howard. Civil resistance in Kosovo. London: Pluto Press, 2000, p. 39. Disponível em: <balkanwitness.glypx.com/civil-resistance-in-kosovo.pdf>. Acesso em: 22 abr. 2017.

${ }^{111}$ CONVENÇÃO sobre direitos e deveres dos Estados. 1993. Disponível em: <http://honoris causa.weebly.com/uploads/1/7/4/2/17427811/convencao_sobre_direitos_e_deveres_dos_estados-12.pdf>. Acesso em: 12 nov. 2016.
} 
constituição de um Estado ocorre com o cumprimento dos seguintes requisitos: uma população permanente, um território determinado, um poder efetivo e sua respectiva capacidade de desenvolver relações internacionais ${ }^{112}$, conforme se observa no art. $3^{\circ}$ da respectiva Convenção:

A existência política do Estado é independente do seu reconhecimento
pelos demais Estados. Ainda antes de reconhecido, tem o Estado o
direito de defender sua integridade e independência, prover a sua
conservação e prosperidade, e consequentemente, organizar-se
como achar conveniente, legislar sobre seus interesses, administrar
seus serviços e determinar a jurisdição e competência dos seus
tribunais.
O exercício destes direitos não tem outros limites além do exercício
dos direitos de outros Estados de acordo com o Direito
Internacional ${ }^{113}$.

O nascimento do Kosovo é consequência da construção doutrinária do direito de secessão, o qual possibilitou independências unilaterais em caso de graves violações de direitos humanos contra populações territorialmente determinadas. Esse aspecto ampliou, no âmbito internacional, garantias de direitos fundamentais das minorias étnicas.

O sujeito que sofreu as graves violações de direitos humanos será o sujeito ativo do direito à autodeterminação para o cumprimento do direito de secessão.

A materialização do direito do povo vítima de graves violações ocorre por meio do elemento objetivo denominado "território", que estabelece o vínculo do povo ao Estado, concedendo legitimidade àqueles habitantes para o exercício do direito à autodeterminação.

O território é o fator de maior importância para a determinação do direito de secessão, sobrepondo-se aos outros critérios objetivos como raça, religião, etnia ou língua.

Nesse sentido, a legitimação do direito de secessão, para uma coletividade ou grupo, deve se vincular a determinado território pertencente ao povo, porque esse direito deve se territorializar, a fim de que essa tutela atinja o maior número de cidadãos em uma delimitação territorial.

\footnotetext{
${ }^{112}$ SILVA, Roberto Luiz. Direito Internacional Público. 2. ed. rev. atual. e ampl. Belo Horizonte: Del Rey, 2002. p. 159.

${ }^{113}$ CONVENÇÃO, 1993.
} 
A justificativa do direito de secessão para os povos minoritários é marcada por um caráter excludente, ainda que não expresso, pois se observa uma discriminação em relação aos grupos raciais, religiosos, étnicos ou nacionais, que são vítimas de graves violações de direitos humanos, dadas as constantes falhas no mecanismo de determinação da vontade coletiva para a defesa dos seus direitos mais relevantes.

Para Allen Buchanan ${ }^{114}$, o direito de secessão deve ocorrer em três situações:

1) nos casos de violações continuadas e sistemáticas em grande escala de direitos humanos;

2) na anexação ilegítima do território de outro Estado;

3) nos casos de constantes violações da autonomia interna de um povo como sua autogestão ou autogoverno.

Esse entendimento é compartilhado por Thomas Musgrave, que aponta a "Teoria do Governo Representativo" com fundamento nos aspectos do território como base para o efetivo exercício da autodeterminação dos povos:

\begin{abstract}
Nesta teoria, o 'povo' é definido como toda a população de uma unidade territorial. A autodeterminação étnica não pode ser um direito humano, já que pertence ao exercício da autodeterminação sobre uma base discriminatória, outorgando-se arbitrariamente somente aqueles que pertencem a um grupo étnico em particular e excluindo os demais. A autodeterminação implica, necessariamente, considerações territoriais de um tipo ou outro. Uma reclamação geral de autodeterminação é não somente a reclamação de um povo para determinar seu próprio status político, mas também representa a reivindicação de um território ${ }^{115}$.
\end{abstract}

114 BUCHANAN, Allen. Justice, legitimacy and self-determination: moral foundations for international law. Oxford: Oxford University Press, 2007. p. 351-353.

115 MUSGRAVE, Thomas D. Self-determination and national minorities. Oxford Monographs in International Law. Oxford: Oxford University Press, 2000. p. 151-180. 'In this theory the 'people' is defined as the entire population of a territorial unit. Ethnic self-determination cannot be a human right because it permits the exercise of self-determination on a discriminatory basis, granting it arbitrarily only to those who belong to a particular ethnic group and excluding all others. Self-determination also necessarily involves territorial considerations of one sort or another. A claim to self-determination is usually not only a claim by a people to determine their own political status, but also represents a claim to territory".

Tradução: Nesta teoria, o "povo" é definido como toda a população de uma unidade territorial. A autodeterminação étnica não pode ser um direito humano, porque permite o exercício da autodeterminação numa base discriminatória, concedendo-a arbitrariamente apenas aos que pertencem a um determinado grupo étnico e excluindo todos os outros. A autodeterminação também implica necessariamente considerações territoriais de um tipo ou de outro. Uma reivindicação à autodeterminação normalmente é não somente uma reivindicação por uma pessoa para determinar seu próprio status político, mas igualmente representa uma reivindicação ao território. 
Nesse sentido, Jorge Julio Urbina ${ }^{116}$ é a favor do exercício territorial por meio do processo de descolonização, ilustrando que, apesar da existência de povos com elementos objetivos em comum, como os aspectos étnicos, religiosos ou raciais, utilizou-se o critério territorial para a outorga do direito de opinião acerca da independência de todas as pessoas que viviam em determinado território.

$\mathrm{Na}$ aplicação da autodeterminação externa no processo descolonizador adotado pelas Nações Unidas deve ser levada em consideração a livre expressão da vontade popular mediante a manifestação de métodos democráticos que possibilitem a efetiva participação da população, pois a descolonização demonstrou que muitos casos de independência ocorreram provocados por uma coletividade popular.

No Parecer consultivo da Assembleia Geral das Nações Unidas sobre as questões relativas ao Sahara Ocidental de 1974117, observa-se que os argumentos da autodeterminação dos povos utilizados no caso do Kosovo, possuem uma linguagem de interação social que define e reforça as normas que serão convertidas no âmbito internacional por meio das relações hegemônicas de poder.

As grandes potências são muito influentes na determinação de uma linguagem necessária para a legitimação de suas ações, propondo conceitos novos nas definições já existentes e, com o tempo, desenvolvendo mudanças no âmbito do Direito Internacional.

Por essas razões, a argumentação jurídica no âmbito internacional possui reflexos além de uma concepção de discursos normativos. Trata-se de uma realidade que pode afetar de maneira substancial a evolução do Direito Internacional, haja vista que seu fundamento está centrado na humanidade, que o ordenamento jurídico internacional deve seguir como critério de interpretação das normas, segurança jurídica e proteção dos direitos fundamentais.

${ }^{116}$ URBINA, Jorge Julio. Las Naciones Unidas y su contribución al desarrollo del princípio de autodeterminación. Derecho: revista jurídica da Universidade de Santiago de Compostela, Santiago de Compostela v. 10, n. 1, p. 197-239. p. 209, 2001. Disponível em: <https://minerva.usc.es/xmlui/ handle/10347/7737>. Acesso em: 13 nov. 2016.

117 ORGANIZAÇÃO DAS NAÇÕES UNIDAS. Corte Internacional de Justiça (CIJ). Parecer consultivo da Assembleia Geral das Nações Unidas sobre as questões relativas ao Sahara Ocidental de 1974-1975. Disponível em: 〈http://www.cedin.com.br/wp-content/uploads/2014/05/pareceres-consultivos_1974.pdf>. Acesso em: 13 nov. 2016. Observa-se a necessidade de determinar a vontade do povo, ainda que em alguns casos, na prática das Nações Unidas, tenha se omitido essa necessidade 
No Parecer Consultivo da Corte Internacional de Justiça, o jurista Antônio Augusto Cançado Trindade ${ }^{118}$, ilustrou sua opinião em relação a Declaração Unilateral de Independência no Kosovo, afirmando que a mesma possui um caráter humanista diante da grave crise humanitária desencadeada na região, porque viola o direito dos povos que habitavam a região e que o Estado deveria protegê-los diante das constantes violações de direitos humanos, intensificadas com a limpeza étnica na região, acirrando o sistema discriminatório das autoridades sérvias contra a população albanesa no Kosovo.

A opinião do jurista foi realizada em separado, juntamente com todas as Resoluções da Assembleia Geral, do Conselho de Segurança, do Conselho Econômico e Social e da Comissão de Direitos Humanos, assim como as considerações do Secretário-Geral da ONU submetidas ao Conselho de Segurança em relação ao ataque das forças sérvias sobre a população albanesa no Kosovo ${ }^{119}$.

No âmbito internacional, nos últimos oitenta anos, observou-se que as organizações internacionais e a expansão do direito dos povos abriram espaço para um processo mais democrático, à medida que esses direitos exigiam maior proteção de direitos no âmbito internacional por meio de tutelas, curadorias e administrações internacionais.

Com esse entendimento, o jurista estabelece uma conexão entre a aplicação do direito de secessão e a violação de direitos humanos, baseado no direito de autodeterminação dos povos e nos limites preceituados pelo Parecer da Corte Internacional de Justiça, que considera excluído de sua alçada o Kosovo atingir ou não sua soberania por intermédio da Declaração Unilateral de Independência, que é um poder estatal supremo e independente em relação ao poder de outros Estados ${ }^{120}$, não analisando, com isso, os direitos dos kosovares, mas essencialmente se a respectiva Declaração viola ou não fundamentos do Direito Internacional Público.

\footnotetext{
118 TRINDADE, Antônio Augusto Cançado. A humanização do Direito Internacional. Belo Horizonte: Del Rey, 2006.

119 NOGUEIRA, Arthur H. V. Kosovo: país ou província? Brasília: Fundação Alexandre de Gusmão (Funag), 2015. Disponível em: <http://funag.gov.br/loja/download/1138-KOSSOVO_Provincia\% 20ou \%20Pais.pdf>. Acesso em: 20 nov. 2016.

${ }^{120}$ SILVA, 2002. p. 165.
} 
Cançado Trindade examina se o Kosovo teria direito decorrente desse processo, já que considera essa questão importante no Direito Internacional contemporâneo, como o respeito a soberania dos Estados até que os direitos humanos sejam efetivamente obedecidos.

Dessa maneira, ocorre o deslocamento dos interesses precípuos da soberania estatal para os direitos dos povos, localizados em um espaço territorialmente determinado, pois não se pode conceber que um Estado utilize o território para destruir seus cidadãos, enquanto deveria protegê-los.

O direito de secessão utilizado no Kosovo deveria garantir a paz, a integridade e a segurança do povo no território, que tinha sido vítima de graves violações de direitos humanos, já que na secessão ocorre a separação de parte de um território soberano e independente, para que haja a formação de outro Estado independente, o qual poderá ou não associar-se ao Estado que dele se separou.

O padrão adotado para o exercício da autodeterminação por meio do direito de secessão é de que um acordo legislativo ou uma intervenção militar legitime esse novo Estado sem a necessária realização de um plebiscito, dada a falta de regulamentação do processo de secessão.

Não sendo realizado um Referendo para a Declaração Unilateral no Kosovo, 0 ato realizado pelo Parlamento Kosovar possui um aspecto para se questionar a vontade direta de um povo no processo de consolidação da sua independência, haja vista que a Resolução Parlamentar utilizada não possui o condão de representar todos os interesses dos povos do Kosovo ${ }^{121}$.

O desenvolvimento da secessão unilateral sem que a comunidade internacional se preocupe no estabelecimento de um mecanismo de consulta ao povo territorialmente determinado, para que ele se manifeste voluntariamente nas demandas políticas que devem ser estabelecidas para sua governança, é admitir que existe uma realidade étnica de um povo, que não merece o devido reconhecimento.

A secessão deve ser o mecanismo adequado para solucionar o problema da violação de direitos fundamentais, e o Estado nascente deve ter o compromisso de zelar pelo Estado de Direito, pela consolidação do processo democrático e pela proteção dos direitos humanos.

${ }^{121}$ GUIMÓN, Julen. El derecho de autodeterminación: el território y sus habitantes. Bilbao: Universidad de Deusto. 1995. p. 35-53. (Serie Derecho). 
A realidade no Kosovo hoje é de uma visão nacionalista de soberania em que a existência de uma comunidade possui direitos apenas formalmente, sem que suas atribuições étnicas, culturais, históricas e raciais sejam verdadeiramente expressas no processo de construção social.

Além disso, as grandes críticas relacionadas à aplicabilidade do direito de secessão seria sua contrariedade ao princípio da integridade territorial, consagrado no artigo $2^{\circ}, \S 4^{\circ}$, da Carta das Nações Unidas e reiterado pela Resolução n. 2.625 de 1970.

No caso do Kosovo, o que se leva em consideração é a segurança das pessoas e a proteção de seus direitos fundamentais, por isso não cabe o entendimento ao contrário.

O interesse maior é a segurança de um povo em um espaço determinado, por isso não ocorre a violação do direito à integridade do território na Sérvia ${ }^{122}$.

As Resoluções n. $1.514^{123}$ e $2.625^{124}$, da Assembleia Geral das Nações Unidas, com a cláusula de salvaguarda no Direito Internacional constituindo o Princípio da unidade territorial e o Princípio da soberania nacional de um Estado, asseguram a integridade de um território.

No entanto, o ataque sistemático a uma parcela de população é um exercício ilegítimo dessa salvaguarda, pois rompe a cláusula de legitimidade e permite a não aplicação excepcional do Princípio da unidade territorial.

O direito de secessão e a integridade territorial podem coexistir como norma de Direito Internacional e, nesse sentido, a opinio juris ${ }^{125}$ tem se consolidado para garantia desses preceitos fundamentais, nos casos de constantes violações de direitos humanos, conforme observa-se o entendimento de James Anaya:

\footnotetext{
122 Deve-se levar em consideração a supremacia jurídica dos Direitos Humanos, por isso não se trata de violação ao Princípio da Unidade Territorial, mas, estritamente, da proteção dos cidadãos como forma de garantir-lhes segurança.

123 ORGANIZAÇÃO DAS NAÇÕES UNIDAS, 1960.

124 ORGANIZAÇÃO DAS NAÇÕES UNIDAS, 1970.

${ }^{125}$ Consiste na convicção do direito, não sendo considerado apenas um acordo tácito ou abstrato de vontades, mas a crença prematura de que os atores da sociedade internacional, criadores daqueles precedentes já referidos de que aquela prática reiterada se estima como obrigatória, pelo fato de ser justa e pertencente ao universo do direito. Conota também, uma convicção positiva dos atores internacionais em agir, levando em conta aquilo que os fatores históricos e sociais do contexto internacional impuseram, sendo esta convicção uma prática obrigatória por ser regra jurídica. MAZZUOLI, Valério de Oliveira. Curso de Direito Internacional. 8. ed. rev. atual. e ampl. São Paulo: Editora Revista dos Tribunais, 2014. p.132-133.
} 
Segundo o Direito Internacional Contemporâneo, a doutrina da soberania e suas afirmações da Carta estão condicionadas pelo valor dos direitos humanos, também expresso na Carta e aceito pela comunidade internacional. Os princípios de autodeterminação e soberania trabalharão em conjunto para promover um mundo pacífico, estável e humano. Porém, quando há uma violação da autodeterminação e dos direitos humanos, as presunções a favor da integridade territorial ou da unidade política dos Estados existentes podem ser compensadas na medida exigida por uma solução apropriada $^{126}$.

Nesse sentido, a nova concepção de soberania é entendida não apenas como um direito, mas também como uma obrigação derivada da responsabilidade de proteger, que obriga a soberania a exercer a proteção dos direitos de seus cidadãos, e não o cometimento de crimes contra eles.

Dessa maneira, o reconhecimento do direito de secessão no Kosovo estabeleceu mecanismos preventivos contra graves violações de direitos que oprimem as minorias de determinado território e contra arbitrariedades realizadas pelo poder de uma maioria. Esse foi relevante precedente no âmbito internacional.

Esse entendimento é compartilhado pelo juiz Cançado Trindade ${ }^{127}$, quando destaca as mudanças que ocorreram nos enfoques jurídicos nos últimos anos, passando de um aspecto que se centralizava essencialmente nos interesses e prerrogativas reconhecidas ao Estado para um aspecto que se fundamenta, principalmente, nos direitos dos povos, a fim de assegurar os preceitos fundamentais como pressuposto de acesso à justiça no Estado Democrático de Direito. Isso possibilita que uma minoria materialize o direito à autodeterminação como forma de garantir sua segurança dentro de suas próprias fronteiras, nos termos da Resolução n. 1.244 de 1999, do Conselho de Segurança das Nações Unidas ${ }^{128}$.

126 ANAYA, James S. Indigenous people in international law. Oxford: Oxford University Press, 2000. p. 85. Under contemporary international law, however, the doctrine of sovereignty and its Charter affirmations are conditioned by the human rights value also expressed in the Charter and embraced by the international community. Self-determination and sovereignty principles will work in tandem to promote a peaceful, stable and humane world. But when there is a violation of self-determination and human rights, presumptions in favor of territorial integrity or political unity of existing states may be offset to the extent required by an appropriate remed.

Tradução: De acordo com o direito internacional contemporâneo, no entanto, a doutrina da soberania e suas afirmações da Carta são condicionadas pelo valor dos direitos humanos também expressos na Carta e abraçados pela comunidade internacional. Os princípios de autodeterminação e soberania trabalharão em conjunto para promover um mundo pacífico, estável e humano. Mas quando há uma violação da autodeterminação e dos direitos humanos, as presunções em favor da integridade territorial ou da unidade política dos estados existentes podem ser compensadas na medida exigida por uma solução apropriada.

127 TRINDADE, Antônio Augusto Cançado. op.cit., 2006.

128 ORGANIZAÇÃO DAS NAÇÕES UNIDAS, 1999. 
O direito de secessão nos casos de violações de direitos humanos deve atender a critérios democráticos, por meio de votações e referendo que expressem a vontade popular no processo social, político e econômico do Estado a que estiverem vinculados.

Um processo democrático não consiste na realização de secessões, que utilize o cerceamento dos direitos pluriétnicos e multiculturais de um povo, já preestabelecido no território com plena capacidade de expressar, de eleger e de determinar o futuro de seu autogoverno, para assegurar o direito à autodeterminação dos povos.

3.2.3 A intervenção humanitária para a proteção de um povo e a doutrina da responsabilidade de proteger

A intervenção da OTAN no Kosovo sem contar com a permissão do CSNU desenvolveu um precedente para o Direito Internacional ${ }^{129}$.

A justificativa para a intervenção foi de que se tratava de uma ação humanitária na qual a comunidade internacional possuía urgente necessidade de conter os graves crimes que se cometiam contra o povo albano-kosovar.

A intervenção de forma unilateral ocasionou grandes debates na doutrina entre a legalidade e a legitimidade ${ }^{130}$ da ação desenvolvida no Kosovo. Nesse sentido, as normas jus cogens ${ }^{131}$ como normas imperativas de Direito Internacional são consideradas essenciais para a proteção dos povos pela comunidade internacional, contra os graves crimes internacionais realizados em desfavor de minorias.

${ }^{129}$ O Conselho de Segurança nada votou, já que não submeteu a votação da intervenção da ONU e resolveu realizála unilateralmente no Kosovo.

${ }^{130}$ ANDRÉS SÁENZ DE SANTA MARIA, Paz. El derecho internacional ante la intervención de la OTAN. In: GIRÓN, José. La intervención de la OTAN en la Republica Federal de Yugoslavia. Gijón: Silverio Cañada, 2002. p. 12.

${ }^{131}$ Jus cogens são as normas peremptórias e imperativas do Direito Internacional, inderrogáveis pela vontade das partes. A primeira referência a esses princípios imperativos internacionais foram realizados por Francisco de Vitória. Os artigos $53^{\circ}$ e $64^{\circ}$ da Convenção de Viena sobre o Direito dos Tratados se referem às normas jus cogens. 
A intervenção da OTAN no Kosovo violava as normas mais elementares que regulamentavam o uso da força e a segurança coletiva ${ }^{132}$, pois somente o CSNU poderia autorizar esse tipo de medida. Isso porque a ação unilateral envolvia uma sociedade internacional com diferentes sujeitos que poderiam utilizar a força quando necessário, violando fundamentos básicos da soberania de outro Estado, desencadeando ações que contrariavam os ditames de jurisdição interna em relação ao sistema de segurança coletiva ${ }^{133}$.

A doutrina da responsabilidade de proteger como medida de segurança internacional busca solucionar um dos maiores impasses conceituais desenvolvidos nas relações internacionais, os quais conjugam o respeito à soberania de um lado e a proteção humanitária de outro, possuindo como aspectos fundamentais:

1) a prevenção como a melhor política, pois enfatiza a diplomacia preventiva reduzindo os riscos de um conflito armado e certos custos humanos inerentes ao processo.

2) a comunidade internacional deve exaurir todos os meios pacíficos de solução de conflito ou ameaça de violência, de forma a utilizar o mínimo de força e a menor instabilidade possível, para que seu objetivo seja realizado de maneira a atender aos preceitos estabelecidos pelo CSNU.

Essa doutrina é considerada um mecanismo que possibilita a prática de intervenções humanitárias nos casos de graves violações, como genocídio, crimes de guerra, crimes contra a humanidade e limpeza étnica. No Kosovo, essas intervenções da ONU foram consideradas por alguns autores como quebra de soberania estatal.

A intervenção realizada pela OTAN, mesmo sem a anuência do CSNU para conter as violações de Direitos Humanos que ocorreram no Kosovo, seria considerada não somente legítima, mas legal.

\footnotetext{
${ }^{132}$ Nesse sentido, a Carta das Nações Unidas estabelece, no artigo 24, que os membros da Organização outorgam ao Conselho de Segurança a responsabilidade de manter a paz e a segurança internacional: "A fim de assegurar pronta e eficaz ação por parte das Nações Unidas, seus Membros conferem ao Conselho de Segurança a principal responsabilidade na manutenção da paz e da segurança internacionais e concordam em que no cumprimento dos deveres impostos por essa responsabilidade o Conselho de Segurança aja em nome deles". (ONU, 1945).

${ }^{133}$ GUTIÉRREZ ESPADA, Cesáreo. Uso de la fuerza, intervención humanitária y libre determinación (la "Guerra de Kosovo"). In: ANUARIO DE DERECHO INTERNACIONAL. Nueva York; Genebra: Naciones Unidas, 2000. v. 16, p. 93-132.
} 
A solução do impasse leva em consideração as dimensões tanto da legitimidade quanto da legalidade na construção da Declaração Unilateral de Independência do Kosovo.

Desde a Conferência das Nações Unidas sobre Direitos Humanos ${ }^{134}$, a comunidade internacional reconheceu que as violações de direitos afirmados em tratados são matérias de legítimo interesse internacional que constituem flexibilização da noção tradicional de Soberania. Segundo Boutros-Ghali135, ex-Secretário-Geral das Nações Unidas:

One of the greatest intellectual demands of our time is to rethink the issue of Sovereignty, emphasizing the rights of individuals and the rights of peoples is a dimension of world Sovereignty, which resides in the whole of humanity and which allows people a legitimate involvement in issues Which affect the world as a whole. It is a movement that increasingly finds expression in the gradual expansion of international law ${ }^{136}$

Nesse sentido, os estudos sobre os aspectos jusnaturalistas, em que 0 homem possui direitos inatos antes de qualquer positivação jurídica estatal, foram retomados diante da preocupação internacional com as graves violações de direitos humanos, por isso as intervenções humanitárias têm sido justificativas para o desencadeamento dessas ações legitimamente consideradas.

Por outro lado, o aspecto da legalidade possui um obstáculo, que é a proibição do uso da força conforme os preceitos estabelecidos na Carta das Nações Unidas, admitindo somente duas exceções: a legítima defesa e a ameaça à paz e à segurança internacional $^{137}$.

${ }^{134}$ ALVES, José Augusto Lindgren. The Viena conference on human. Lua Nova [online], n. 32, p. 170-180, 1994. Disponível em: 〈http://dx.doi.org/10.1590/S0102-64451994000100009>. Acesso em: 13 nov. 2016.

${ }^{135}$ BOUTROS-GHALI, B. Empowering the United Nations. Foreign Affairs. v. 89, p. 98-99, 1992. Disponível em: 〈https://www.foreignaffairs.com/articles/1992-12-01/empowering-united-nations〉. Acesso em: 23 nov. 2016.

${ }^{136}$ Tradução: Uma das maiores exigências intelectuais de nosso tempo é repensar a questão da Soberania, enfatizar os direitos dos indivíduos e os direitos dos povos é uma dimensão da Soberania mundial, que reside em toda a humanidade e que permite às pessoas um envolvimento legítimo em questões que afetam o mundo como um todo. É um movimento que cada vez mais se expressa na expansão gradual do Direito Internacional.

137 BIERRENBACH, Ana Maria. O conceito de responsabilidade de proteger e o Direito Internacional humanitário. Brasília, DF: Fundação Alexandre de Gusmão, 2011. p. 23-24. 
Dessa forma, a solução da comunidade internacional para a autodeterminação interna no Kosovo ocorreu por meio da Resolução n. 1.244, do Conselho de Segurança das Nações Unidas - CSNU ${ }^{138}$, sem que houvesse o questionamento do princípio da unidade territorial da Sérvia, já que a missão internacional acreditava no cumprimento da segurança necessária do governo autônomo para o Kosovo mediante autonomia substancial, respeitando a Soberania e a integridade territorial da República Federativa da lugoslávia.

Nesse sentido, a intervenção da OTAN materializou o reconhecimento do direito de autodeterminação interna no Kosovo, aspecto fundamental para a Declaração Unilateral de independência e aceitação do direito de secessão na região.

Assim, a operação da OTAN no Kosovo, sob o fundamento de uma intervenção humanitária, possibilitou amplo debate em relação à Soberania dos Estados, para garantia dos Direitos Humanos contra os intensos abusos desencadeados sobre as minorias étnicas.

Nesse momento no âmbito internacional não sabia como agir legitimamente nos casos de abusos contra povos em um Estado Soberano, pois era imprescindível respeitar os assuntos internos de cada Estado e submeter as demandas ao Conselho de Segurança das Nações Unidas (CSNU) somente se afetassem a segurança internacional, caso contrário, deveria haver intervenção para conter graves violações de Direitos Humanos, mesmo sem o consentimento do Conselho de Segurança da ONU.

Secretário-Geral das Nações Unidas, Kofi Annan, abordou o problema ao afirmar na Assembleia Geral ${ }^{139}$ :

If States engaged in criminal behavior know that borders are not absolute; If they know that the Security Council will take action to stop crimes against humanity, then they will not embark on such a course of action in the expectation of sovereign impunity ${ }^{140}$.

It has revealed the core challenge to the Security Council and to the United Nations as a whole in the next century: to forge unity behind the

\footnotetext{
138 ORGANIZAÇÃO DAS NAÇÕES UNIDAS (ONU). Conselho de Segurança. Resolução n. 1.244, de 10 de junho de $1999 . \quad$ Disponível $\quad$ em: ny.un.org/doc/UNDOC/GEN/N99/172/89/PDF/N9917289.pdf?OpenElement>. Acesso em: 21 abr. 2017.

139 INFORME anual da Assembleia Geral das Nações Unidas de 20 de setembro de 1999. Disponível em: <http://www.un.org/press/en/1999/19990920.sgsm7136.html>. Acesso em: 8 nov. 2016.

140 Tradução: Se os Estados envolvidos em comportamento criminoso souberem que as fronteiras não são absolutas; Se eles souberem que o Conselho de Segurança tomará medidas para acabar com os crimes contra a humanidade, então eles não embarcarão nessa linha de ação na expectativa de impunidade soberana.
} 
principle that massive and systematic violations of human rights wherever they may take place -- should not be allowed to stand ${ }^{141}$.

Objetivando promover uma solução para o problema estabelecido, o Secretário-Geral constituiu, no Canadá, uma Comissão Internacional sobre a Intervenção e a Soberania dos Estados (CIISE) em setembro de 2000. A finalidade dessa comissão era construir acordos para uma intervenção humanitária com sua respectiva vinculação aos Estados, respeitando os princípios do Direito Internacional, os direitos humanos e a não intervenção nos assuntos internos de cada Estado. Isso porque os limites de cada direito mencionado estavam suscitando grandes instabilidades sociopolíticas na comunidade internacional.

Assim, a CIISE concluiu um informativo em dezembro de 2001, denominado a "Responsabilidade de Proteger" (The Responsability to Protect), constando nas conclusões os aspectos da Soberania que englobam as responsabilidades de um Estado pela proteção da sua população ${ }^{142}$.

Esse fato ocasionou uma visão revolucionária em relação ao princípio da soberania nacional, pois foi considerado um aspecto fundamental para o Direito Internacional, e a soberania passava a ser, além de um simples direito, um dever que ocasionaria responsabilidades pelo seu amplo exercício.

A doutrina da responsabilidade de proteger devia agir sobrepondo-se ao princípio da não intervenção, quando uma população estivesse sofrendo graves violações de direitos e o Estado não quisesse ou não pudesse atacar com a finalidade de evitar danos irreparáveis à população sob sua responsabilidade.

No caso de não cumprimento por parte dos Estados para proteger os direitos dos cidadãos, a ONU interviria impedindo violações de garantias fundamentais a fim de assegurar os direitos humanos.

Considerando que a legitimidade se sobrepõe à legalidade na situação cima, pode-se considerar que uma intervenção sem permissão prévia do CSNU é uma exceção ao seu monopólio para o uso da força.

\footnotetext{
${ }^{141}$ Tradução: Revelou o principal desafio para o Conselho de Segurança e para as Nações Unidas como um todo no próximo século: forjar a unidade por trás do princípio de que as violações maciças e sistemáticas dos direitos humanos onde quer que ocorram não sejam permitidas.

${ }^{142}$ COMISSÃO INTERNACIONAL SOBRE A INTERVENÇÃO E A SOBERANIA DOS ESTADOS (CIISE). The responsibility to protect. Disponível em: <www.responsibilitytoprotect.org/ICISS\%20Report.pdf>. Acesso em: 9 nov. 2016.
} 
Trata-se de um aspecto importante na construção e consolidação dos direitos humanos, baseado na doutrina da responsabilidade de proteger e sob a responsabilidade internacional das Nações Unidas.

Os mecanismos de segurança coletiva também visam proteger o povo nos casos de violação aos direitos humanos, distanciando-se da visão clássica de inviolabilidade da soberania, como Hans Kelsen a concebe, por meio da unidade de uma ordem, enquanto Miguel Reale a define como o poder jurídico de organização nos territórios soberanos para a universalidade dos direitos ${ }^{143}$.

A soberania pode ser invocada tanto no sentido de independência, sobretudo em relação aos direitos dos povos, como no de expressão de outorga jurídica suprema, capaz de assegurar, nos limites de cada jurisdição, a eficácia dos preceitos normativos.

Do ponto de vista das relações internacionais, uma inadequação na intervenção humanitária pode ocorrer, dado o dualismo inerente à Soberania, já que internamente ela está baseada na vontade dos cidadãos, por meio da soberania popular, outorgando legitimidade ao Estado.

Externamente, a soberania não está ligada à legitimidade, mas à unidade e à independência do Estado diante de outros Estados soberanos. Assim, a perda da legitimidade de um regime não justifica qualquer intervenção humanitária, tampouco coloca em risco a soberania de um Estado, haja vista que legitimidade é um problema interno de cada Estado e sua respectiva instituição política, conforme se observou na Declaração Unilateral de Independência no Kosovo.

A responsabilidade de proteger acaba sendo um instrumento que fomenta um imperialismo baseado no discurso de proteger com a intenção de violar a autonomia política e a soberania dos Estados mais frágeis.

Para evitar esse entendimento na doutrina, porém, a responsabilidade de proteger estabeleceu limites de sua atuação por meio das finalidades humanitárias, baseadas na imparcialidade das situações de crise em que houver intervenção militar, no caso da OTAN no Kosovo, para a garantia dos Direitos Humanos em relação aos povos habitantes nas suas fronteiras ${ }^{144}$.

\footnotetext{
${ }^{143}$ REALE, Miguel. Teoria do Estado e do direito. 5. ed. São Paulo: Saraiva, 2003. p. 127.

${ }^{144}$ BANNON, Alicia L. The responsibility to protect: the UN world summit and the question of unilateralism. The Yale Law Journal, v. 115, n. 5, 2006. Disponível em: <http://www.yalelawjournal.org/comment/theresponsibility-to-protect-the-un-world-summit-and-the-question-of-unilateralism>. Acesso em: 10 nov. 2016.
} 
A doutrina da responsabilidade de proteger obteve reflexo positivo na ampliação do conceito de liberdade em relação ao desenvolvimento, à segurança e aos direitos humanos, assim como na Ata final do cumprimento mundial em $2005^{145}$, apresentada pela Assembleia Geral das Nações Unidas e reafirmada pelo Conselho de Segurança das Nações Unidas (CSNU) em diversas Resoluções, por exemplo, a Resolução n. 1.674, de 28 de abril de 2006 e a Resolução n. 1.894, de 11 de novembro de $2009^{146}$.

No Relatório do Secretário-Geral das Nações Unidas, Ban Ki-moon também houve considerações em relação à responsabilidade de proteger, que levou ao nascimento de um novo princípio no Direito Internacional não contemplado até o presente momento pela Carta das Nações Unidas, ocasionando uma mudança significativa nas considerações tradicionais de soberania dos Estados.

Ollé ${ }^{147}$ analisa a soberania como limite a justiça internacional, já que a comunidade internacional deve interferir quando houver insuficiência na proteção dos direitos humanos e violação de garantias fundamentais dos cidadãos, para que os Tratados de Direitos Humanos Internacionais não se transformem em meros instrumentos normativos no ordenamento jurídico interno.

A nova concepção de soberania seria desenvolvida não apenas como um direito, mas também como uma obrigação de Direito Internacional para a proteção da humanidade contra graves crimes, que comprometessem os direitos dos cidadãos ou dificultassem a autodeterminação dos povos.

Dessa forma, a responsabilidade de proteger é considerada um princípio que desencadeia obrigações no âmbito da comunidade internacional, levando em consideração a soberania, os Estados e o povo, como fundamentos importantes para garantia dos direitos humanos no âmbito do Direito Internacional ${ }^{148}$.

\footnotetext{
${ }^{145}$ ORGANIZAÇÃO DAS NAÇÕES UNIDAS (ONU). Assembleia Geral. Ata final do cumprimento mundial em 2005. Disponível em: <http://www.ifrc.org/docs/idrl/I520EN.pdf>. Acesso em: 9 nov. 2016.

146 THE RESPONSIBILITY to protect. 2001. Disponível em: <http://responsibilitytoprotect.org/ICISS\%20 Report.pdf>. Acesso em: 10 nov. 2016.

${ }^{147}$ OLLÉ, Manuel. Justicia universal para crímenes internacionales. Madrid: La Ley, 2008. p. 271.

148 BELlAMY, Alex J.; DAVIES, Sara E.; GLANVILLE Luke (Ed.), The responsability to protect and international law. Boston: Martinus Nijhoff Publishers. 2011. p. 5.
} 


\subsection{A internacionalização da autodeterminação dos povos indígenas para o ordenamento jurídico}

Com a adoção da Carta da ONU a partir de 1945, no pós-Segunda Guerra, que o Direito Internacional dos Direitos Humanos iniciou o desenvolvimento e se efetivou autonomamente no Direito Internacional Público.

Anteriormente existiam nos de proteção de direitos humanos, porém faltava um sistema normativo específico que protegesse aos indivíduos de sua condição de ser humano, para a garantia da dignidade da pessoa humana.

A criação das Nações Unidas e suas agências de especializadas de proteção, houve a intensificação do processo de internacionalização dos direitos humanos, demarcando o surgimento de uma nova ordem internacional que instaura um novo modelo de realização para as condutas internacionais, com inclusão de pautas cujo seu interesse é de amplitude internacional, como: a manutenção da paz e segurança internacional, o desenvolvimento de relações amistosas entre Estados, o alcance da cooperação internacional no plano econômico, social e cultural, para o desenvolvimento de "padrão internacional" para a proteção internacional dos direitos humanos e criação de uma nova ordem econômica.

O respeito às liberdades fundamentais e aos direitos humanos, com a consolidação da Carta da ONU, se tornaram uma preocupação internacional à medida que, os problemas internos dos Estados e suas relações com os cidadãos integram um cenário global de proteção, levando em consideração a cooperação internacional e o desenvolvimento das relações entre Nações.

$\mathrm{Na}$ Carta das Nações Unidas ${ }^{149}$, alguns dispositivos fazem referência expressa à proteção dos direitos humanos e liberdades fundamentais, conforme se observa a seguir:

Art. 1ํ Os objetivos das Nações Unidas são: [...] 3. Realizar a cooperação internacional, resolvendo os problemas internacionais de caráter econômico, social, cultural ou humanitário, promovendo e estimulando o respeito pelos direitos humanos e pelas liberdades fundamentais para todos, sem distinção de raça, sexo, língua ou religião;

Art. 13으 A Assembleia Geral promoverá estudos e fará recomendações, tendo em vista: [...] b) Fomentar a cooperação

149 CARTA DA ORGANIZAÇÃO DAS NAÇÕES UNIDAS (ONU). Disponível em: <https://nacoes unidas.org/carta/>. Acesso em: 16 maio 2017. 
internacional no domínio econômico, social, cultural, educacional e da saúde e favorecer o pleno gozo dos direitos humanos e das liberdades fundamentais, por parte de todos os povos, sem distinção de raça, sexo, língua ou religião.

Art. 55 Com o fim de criar condições de estabilidade e bem-estar, necessárias às relações pacíficas e amistosas entre as Nações, baseadas no respeito do princípio da igualdade de direitos e da autodeterminação dos povos, as Nações Unidas promoverão: [...] c) $O$ respeito universal e efetivo dos direitos humanos e das liberdades fundamentais para todos, sem distinção de raça, sexo, língua ou religião.

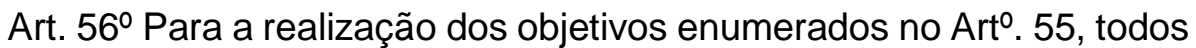
os membros da Organização se comprometem a agir em cooperação com esta, em conjunto ou separadamente.

Art. $62^{\circ}$ 2. Poderá fazer recomendações destinadas a assegurar 0 respeito efetivo dos direitos humanos e das liberdades fundamentais para todos.

Art. 68ํำ Conselho Econômico e Social criará comissões para os assuntos econômicos e sociais para a proteção dos direitos humanos, assim como outras comissões necessárias ao desempenho das suas funções.

Art. $76^{\circ}$ As finalidades básicas do regime de tutela, de acordo com os objetivos das Nações Unidas enumerados no Art. $1^{\circ}$ da presente Carta, serão: [...] c) Estimular o respeito pelos direitos humanos $e$ pelas liberdades fundamentais para todos, sem distinção de raça, sexo, língua ou religião, e favorecer o reconhecimento da interdependência de todos os povos.

Esse instrumento jurídico internacional não define os direitos humanos, não sendo considerado um obstáculo para sua obrigatoriedade. Sendo, portanto, obrigação dos Estados de compreendê-los como regras jurídicas universais plenamente válidas e não como meras declarações de princípios. Deixando assim, em aberto, sua efetiva aplicação nos seus diversos significados.

Nesse sentido, o fato da Carta das Nações Unidas não ter conceituado o que vem a ser os "direitos humanos e as liberdades fundamentais" ela impulsionou pioneiramente a "universalização" dos direitos da pessoa humana ao reconhecer que a pauta é de legítimo interesse internacional.

Antes o assunto era restrito ao âmbito interno dos Estados que ao ratificarem a Carta, considerada um instrumento jurídico multilateral, reconhecem que possuem obrigações relativas à proteção e promoção dos direitos humanos tanto em relação a 
si mesmos e os indivíduos que habitam seus territórios, quanto em relação aos outros Estados.

Contudo, as origens dos direitos humanos remontam às revoluções liberais do século XVIII, em particular a Revolução Francesa e a Declaração dos Direitos do Homem e do Cidadão (1789), em que se procurou transformar os direitos humanos provenientes de um contexto particular, para o alcance verdadeiramente universal, capaz de atender aos preceitos de uma sociedade democrática.

Essa concepção particular tem sido baseada no liberalismo político marcadamente individualista e com ênfase nos direitos civis e políticos em detrimento dos direitos dos econômicos, sociais e culturais.

Outro grande documento fundamental da concepção universal dos direitos humanos é a Declaração Universal dos Direitos Humanos ${ }^{150}$, aprovada em 1948 pela Assembleia Geral das Nações Unidas, que tentou oferecer uma legitimação universal a uma doutrina fundamentalmente eurocêntrica e as tradições não ocidentais foram marginalizadas, uma vez que as sociedades asiáticas e africanas, em sua maioria, ainda eram colônias europeias, o que as impedia de participar igualmente no desenvolvimento da respectiva Declaração Universal.

Os povos indígenas não foram levados em consideração para discutir o conteúdo dessa Declaração, que tinha pretensões de caráter universal.

Essa ausência de participação dos povos indígenas continuou nos principais tratados internacionais que vieram a desenvolver os preceitos da Declaração Universal. Nesse sentido, pode-se observar que os povos indígenas estiveram sistematicamente excluídos do processo de discussão e aprovação dos principais instrumentos internacionais para a proteção dos direitos humanos.

A consagração internacional dos direitos humanos após a Segunda Guerra Mundial com a criação da ONU e a adoção da Declaração Universal dos Direitos Humanos de 1948 foram utilizadas para a proteção dos povos indígenas em situação de "invisibilidade" durante séculos de discriminação e exclusão social.

Nas décadas de 1970 e 1980, houve avanços no reconhecimento dos direitos aos povos indígenas como atores políticos e sujeitos de direitos. Dessa maneira, ocorreu um processo de conscientização dessas minorias éticas como atores de direitos sociais plenamente capazes.

${ }^{150}$ ORGANIZAÇÃO DAS NAÇÕES UNIDAS, 1948. 
Esse processo evoluiu com a Convenção n. 107 e a Convenção n. 169 da OIT sobre Povos Indígenas e Tribais em Países Independentes, aprovada pela OIT em 1989. Sendo que, a Convenção n. 169 da OIT é considerada um relevante instrumento normativo de proteção e promoção dos direitos indígenas.

$\mathrm{Na}$ década de 1990, ocorreu um importante processo de reconhecimento constitucional dos direitos indígenas na maioria dos países da América Latina, denominado "constitucionalismo multicultural".

Por fim, a última década do século XX também foi siginificativa no processo de institucionalização internacional de reivindicações indígenas. Essas minorias étnicas tiveram delineados seus interesses no campo das Nações Unidas, por meio da Resolução n. 61/295 ${ }^{151}$, aprovada em 13 de setembro de 2007, que consolidou a Declaração das Nações Unidas sobre os Direitos dos Povos Indígenas.

A Convenção n. 169 sobre povos indígenas e tribais da OIT, adotada em Genebra, em 27 de junho de $1989^{152}$ e tendo o Brasil como signatário desde 2002, tentou sanar a ineficácia dos mecanismos de proteção aos direitos indígenas vigentes no ordenamento jurídico interno de cada país.

De acordo com a Convenção, os povos indígenas devem ser respeitados e sua cultura deve ser utilizada como fomento de garantia para sua organização social dentro dos Estados Soberanos.

O objetivo da Organização Internacional do Trabalho (OIT) é melhorar as condições de trabalho e de vida desses povos, consolidando políticas sociais próprias que lhes assegurem os direitos étnicos como forma de garantir os preceitos estabelecidos na Constituição Federal e demais instrumentos internacionais de proteção aos direitos humanos.

A Convenção n. 169 da OIT tornou-se um elemento fundamental para a autonomia dos povos indígenas e reconhecimento da diferença ${ }^{153}$ como vetor de desenvolvimento social, a fim de superar a "invisibilidade" e a marginalização histórica que os povos estiveram submetidos.

${ }^{151}$ ORGANIZAÇÃO DAS NAÇÕES UNIDAS. Assembleia Geral. Resolução 61/295, 13 de setembro de 2007. Disponível em: <https://documents-ddsny.un.org/doc/UNDOC/GEN/N06/512/10/PDF/N0651210.pdf?OpenElement>. Acesso em: 9 dez. 2016.

${ }^{152}$ BRASIL. Decreto n. 5.051 de 19 de abril de 2004. Promulga a Convenção n. 169 da Organização Internacional do Trabalho (OIT) sobre Povos Indígenas e Tribais. Diário Oficial da União. Brasília, 20 abr. 2004. Disponível em: <http://www.planalto.gov.br/ccivil_03/_ato2004-2006/2004/decreto/d5051.htm〉. Acesso em: $12 \mathrm{dez}$. 2016.

${ }^{153}$ SOUZA, Jessé. A construção social da subcidadania: para uma sociologia política da modernidade periférica. Belo Horizonte: UFMG, 2003. p. 76. 
Sendo considerada o primeiro instrumento internacional de reconhecimento do direito à autodeterminação dos povos indígenas e tribais, que objetiva garantir a identidade indígena no processo histórico de desenvolvimento cultural, de acordo com o artigo $1^{\circ}$ da respectiva Convenção, em que os povos tribais em países independentes cujas condições sociais, culturais e econômicas os distingam de outros segmentos da comunidade nacional e cuja situação seja regida, total ou parcialmente, por seus próprios costumes, tradições, por uma legislação ou regulações especiais.

Havendo o reconhecimento de caráter particular das culturas, tradições e crenças que permeiam os direitos dessas minorias étnicas, para que estes possam gozar de suas liberdades fundamentais e promover seu desenvolvimento econômico, social e cultural. 


\section{A PROTEÇÃO INTERNACIONAL DOS POVOS INDÍGENAS NO ÂMBITO DA ORGANIZAÇÃO DAS NAÇÕES UNIDAS SOB A PERSPECTIVA DA ISONOMIA}

A Declaração dos Direitos das Pessoas Pertencentes a Minorias, aprovada por unanimidade na Assembleia Geral das Nações Unidas em sua Resolução 47/135 de 18 de dezembro de 1992, carecendo da definição de minoria que será assimilada pelas minorias étnicas, religiosas e linguísticas às minorias nacionais. Desse modo, a proteção do direito para a identidade das minorias inclui a possibilidade de um tratamento diferenciado para a existência de direitos especiais, como os direitos de participação na tomada de decisões políticas, apesar das obrigações estatais ainda serem ineficazes na garantia desses direitos.

\subsection{A proteção das minorias na Declaração das Nações Unidas sobre os Direitos dos Povos Indígenas}

A inspiração para a criação da declaração, segundo Norberto Bobbio, vem de John Locke, para quem o direito de igualdade é direito a igual liberdade ${ }^{154}$.

Nesse sentido, as declarações de direitos possuem um valor histórico de destaque como matriz do Direito Constitucional moderno para a proteção dos direitos humanos, pois as Constituições contemporâneas fazem referência, de maneira direta ou indireta, a tais Declarações.

As convenções e os tratados possuem duas dimensões impositivas sobre as Nações e Estados Nacionais: a primeira, quando o Estado contribui na sua elaboração e a segunda, quando o Estado adere ao seu conteúdo, fazendo-o integrar, em maior ou menor grau, a ordem normativa interna.

As declarações de direitos produziram efeitos após a Segunda Guerra Mundial, com a criação da Carta das Nações Unidas em 1945, fortalecendo a internacionalização dos direitos humanos.

Um dos fatores que contribuíram para esse fortalecimento foi o expressivo crescimento de organizações internacionais com a finalidade de promover a cooperação, com base no consenso de Estados.

${ }^{154}$ BOBBIO, Norberto. A era dos direitos. Tradução de Carlos Nelson Coutinho. Apresentação Celso Lafer. Rio de Janeiro: Elsevier, 2004. p. 70. 
Essas organizações têm como objetivo conduzir as relações internacionais para manutenção da paz e da segurança, buscando a cooperação nas esferas econômica, social e cultural para garantir a proteção internacional dos direitos humanos ${ }^{155}$.

A promoção dos direitos humanos vem regulamentada no art. 55, alínea c da Carta das Nações Unidas ${ }^{156}$ e determina, sob a forma de respeito aos princípios da igualdade de direitos e autodeterminação:

Com o fim de criar condições de estabilidade e bem-estar, necessárias às relações pacíficas e amistosas entre as Nações, baseadas no respeito do princípio da igualdade de direitos e da autodeterminação dos povos, as Nações Unidas promoverão: [...] c) O respeito universal e efetivo dos direitos do homem e das liberdades fundamentais para todos, sem distinção de raça, sexo, língua ou religião.

O art. 56 da Carta das Nações Unidas também reafirma que é dever dos Estados Membros cooperar com a própria organização para atingir o que está proposto no artigo 55 do respectivo instrumento normativo.

Os Estados Membros têm a obrigação de promover os direitos humanos não somente no âmbito interno, mas também no âmbito internacional, e a ONU tem o encargo de assegurar o cumprimento desses deveres exigindo dos Estados que não permitam a violação desses direitos.

O referido processo de universalização possui antecedentes notáveis, os quais são exemplificados pela Declaração dos Direitos do Homem e do Cidadão'157, aprovada pela Assembleia Nacional da França em agosto de 1789, cujo fundamento é decorrente da expansão dos ideais de igualdade consagrados nas liberdades individuais e servindo de preâmbulo à Constituição de 1791.

A Declaração Universal dos Direitos Humanos foi instituída em 10 de dezembro de 1948, possuindo um teor inovador e universal como propósito principal para a ordem pública mundial, apoiada no respeito à dignidade humana.

Além da universalidade dos direitos humanos, essa declaração associa os direitos civis e políticos aos direitos econômicos, sociais e culturais.

\footnotetext{
155 PIOVESAN, 1997. p. 125-126.

156 ORGANIZAÇÃO DAS NAÇÕES UNIDAS, 2008.

157 FRANÇA. Assembleia Nacional Constituinte. Declaração dos direitos do homem e do cidadão, 1979. Disponível em: <http://pfdc.pgr.mpf.mp.br/atuacao-e-conteudos-de-apoio/legislacao/direitoshumanos/declar_dir_homem_cidadao.pdf>. Acesso em: 12 nov. 2016.
} 
Desse modo, o valor da liberdade se concilia com o valor da igualdade, harmonizando o discurso liberal da cidadania com o discurso social ${ }^{158}$.

A Declaração Universal de $1948^{159}$ foi instituída sob a forma de resolução, não apresentando força de lei, porém possui força vinculante, pois promove o reconhecimento universal dos direitos humanos e das liberdades fundamentais, de acordo com a Carta das Nações Unidas. Ela é considerada um código de atuação e conduta que os Estados-Membros das Nações Unidas têm o dever de observar, influenciando nas ordens jurídicas nacionais, visto que seus direitos estabelecidos têm sido adotados pelas Constituições.

A Declaração Americana dos Direitos e Deveres do Homem, aprovada em abril de 1948, em Bogotá, reconheceu e definiu os direitos do homem, estabelecendo normas de conduta obrigatórias, tendentes à promoção e proteção dos direitos humanos, criando órgãos destinados a zelar pela fiel observância.

Nesse sentido, essa Declaração possui seu fundamento orientado pelos preceitos dos direitos humanos. No Preâmbulo dessa declaração, existe a clara noção de igualdade, quando equipara todos em direito e dignidade:

Todos os homens nascem livres e iguais em dignidade e direitos e, como são dotados pela natureza de razão e consciência, devem proceder fraternalmente uns para com os outros.

O cumprimento do dever de cada um é exigência do direito de todos. Direitos e deveres integram-se correlativamente em toda a atividade social e política do homem. Se os direitos exaltam a liberdade individual, os deveres exprimem a dignidade dessa liberdade ${ }^{160}$.

A igualdade como pressuposto para a consolidação dos direitos humanos, vem assegurada na garantia dos direitos civis e políticos:

Artigo 3.․ Os Estados partes do presente Pacto comprometem-se a assegurar a homens e mulheres igualdade no gozo de todos os direitos civis e políticos enunciados no presente pacto.

Artigo 26. Todas as pessoas são iguais perante a lei e têm direito, sem discriminação alguma, a igual proteção da lei. A esse respeito, a lei deverá proibir qualquer forma de discriminação e garantir a todas as

\footnotetext{
158 PIOVESAN, 1997. p. 136-138.

159 ORGANIZAÇÃO DAS NAÇÕES UNIDAS PARA A EDUCAÇÃO, A CIÊNCIA E A CULTURA (UNESCO). Assembleia Geral. Declaração universal dos direitos humanos. 1948. Disponível em: <http://unesdoc.unesco.org/images/0013/001394/139423por.pdf>. Acesso em: 10 nov. 2016.

${ }^{160}$ ORGANIZAÇÃO DAS NAÇÕES UNIDAS, 1948.
} 
pessoas proteção igual e eficaz contra qualquer discriminação por motivo de raça, cor, sexo, língua, religião, opinião política ou de outra natureza, origem nacional ou social, situação econômica, nascimento ou qualquer outra situação ${ }^{161}$.

No fenômeno da universalização e da multiplicação de direitos do homem, dessa forma, observa-se uma mudança do ente genérico para o homem específico ${ }^{162}$ como forma de garantir igualdade de tratamento nos tribunais ou órgãos de administração da justiça, sem o estabelecimento de diferenças em virtude de raça, cor, nacionalidade ou etnia.

$\mathrm{Na}$ opinião de Maria José Fariñas ${ }^{163}$, a pretensão da universalidade é como uma ficção de legitimação que contém um domínio de hegemonia mundial. O que é descrito como universal é basicamente a tentativa de universalizar a concepção particular de direitos humanos.

Essa concepção particular tem sido baseada no liberalismo político marcadamente individualista com ênfase nos Direitos Civis e Políticos em detrimento dos Direitos Econômicos, Sociais e Culturais.

Para a construção do conceito universal de direitos humanos, não se pode aceitar uma concepção somente ocidental, mas a construção de um diálogo com diferentes visões de mundo, disposta a aumentar suas visões pluriétnicas e multiculturais para a garantia dos direitos humanos das minorias.

A ausência de menção aos povos indígenas nos principais tratados internacionais tem contribuído sistematicamente para sua exclusão do processo de discussão e aprovação nos principais instrumentos internacionais para a proteção dos direitos humanos.

Observa-se que o Pacto Internacional sobre os Direitos Civis e Políticos (PIDCP $)^{164}$ e o Pacto Internacional sobre os Direitos Econômicos, Sociais e Culturais (PIDESC) não realizaram referência aos direitos dos povos indígenas, embora ambos contivessem, em seu artigo 1, um direito expresso à autodeterminação dos povos, conforme se observa a seguir:

\footnotetext{
${ }^{161}$ ORGANIZAÇÃO DAS NAÇÕES UNIDAS, 1948.

${ }^{162}$ BOBBIO, Norberto, op. cit. p. 67-69.

${ }^{163}$ FARIÑAS DULCE, Maria José. Globalización, ciudadanía y derechos humanos, Dikynson. Cuadernos Bartolomé de las Casas, Madrid, n. 16, 2000.

164 ORGANIZAÇÃO DAS NAÇÕES UNIDAS. Assembleia Geral. Pacto internacional de direitos civis $e$ políticos. 1976. Disponível em: 〈http://www.refugiados.net/cid_virtual_bkup/asilo2/2pidcp.html〉. Acesso em: 10 nov. 2016.
} 
Todos os povos têm o direito de autodeterminação. Em virtude desse direito estabelecem livremente o seu estatuto político, promovendo o seu desenvolvimento econômico, social e cultural ${ }^{165}$.

As primeiras demandas indígenas ocorrem mediante o reconhecimento de que o artigo 27 do Pacto Internacional sobre os Direitos Civis e Políticos concedeu às pessoas pertencentes a minorias étnicas, religiosas ou linguísticas:

Nesses Estados em que as minorias étnicas, religiosas ou linguísticas não será negado às pessoas pertencentes a essas minorias que gozem de seus direitos, conjuntamente com os outros membros do seu grupo, a possuir sua cultura própria, de professar e praticar a sua própria religião e de usar sua própria língua ${ }^{166}$.

Os direitos dos povos indígenas foram incluídos na categoria de minorias no Comitê de Direitos Humanos, órgão que zela pela correta implementação do Pacto Internacional sobre os Direitos Civis e Políticos por parte dos Estados.

A mudança que pode ser observada ao longo do processo histórico refere-se ao fato de que os povos indígenas estão exigindo direitos coletivos não apenas quanto à indivíduos titulares de direitos, mas como um grupo considerado coletivamente.

As origens dos direitos humanos não levaram em consideração a realidade dos povos indígenas nos instrumentos internacionais aprovados após a Segunda Guerra Mundial, sendo ausentes no pronunciamento das demandas indígenas.

Com o aumento da visibilidade dos povos indígenas, iniciou-se crescente questionamento acerca da universalidade dos direitos humanos em relação a essas minorias étnicas e o aspecto mais complexo para garantia desses direitos, era acomodar as demandas indígenas em um conceito de direitos humanos universais cuja concepção de povo estava ausente.

A partir desse momento, ocorreu o avanço no sentido de uma concepção mais aberta dos direitos humanos para o conceito de diversidade cultural como forma de compreender a dignidade humana.

A Assembleia Geral das Nações Unidas, na Declaração sobre os Direitos dos Povos Indígenas de 13 de setembro de $2007^{167}$, adotou o recente marco no processo de afirmação dos Direitos Humanos dos povos indígenas.

165 ORGANIZAÇÃO DAS NAÇÕES UNIDAS, 1976.

166 ORGANIZAÇÃO DAS NAÇÕES UNIDAS, 1976.

${ }^{167}$ ORGANIZAÇÃO DAS NAÇÕES UNIDAS. Assembleia Geral. Resolução n. 61/295, 13 de setembro de 2007. Disponível em: 〈http://www.un-documents.net/a61r295.htm〉. Acesso em: 9 dez. 2016. 
Considerado o primeiro documento que se refere às injustiças históricas sofridas pelos povos indígenas, sua aprovação é interpretada como um sinal de compromisso com o passado como mecanismo de reparação a um processo de exploração e dominação em que os índios estiveram submetidos.

No preâmbulo da Declaração sobre os Direitos dos Povos Indígenas, a Assembleia Geral das Nações Unidas declarou:

Preocupado com os povos indígenas, o fato que aqueles foram vítimas de injustiças históricas como resultado, entre outras coisas, a sua colonização e expropriação de suas terras, territórios e recursos, impedindo-os assim de exercer, em particular o seu direito ao desenvolvimento, de acordo com suas próprias necessidades e interesses ${ }^{168}$.

Além da preocupação expressa pela Assembleia Geral em relação às injustiças históricas, há outro elemento evidente nesse pronunciamento, que é o nexo de causalidade estabelecido entre a colonização e a expropriação dos bens naturais sofridos pelos povos indígenas, os quais dificultaram seu direito ao desenvolvimento.

O artigo 20 da Declaração sobre os Direitos dos Povos Indígenas reconhece que "os povos indígenas despojados de seus meios de subsistência e desenvolvimento têm direito a reparação justa e eqüitativa".

Embora essa disposição não seja clara ao se referir às privações sofridas pelos povos indígenas, pode-se argumentar que essas injustiças explicam, em grande parte, as exclusões dessas minorias étnicas, tornando-as credoras de tal reparação. Nesse sentido, o artigo 28 estabelece:

Os povos indígenas têm direito à reparação, por meios que podem incluir restituição ou, se tal não for possível, uma compensação justa e equitativa, para as terras, territórios e recursos tradicionalmente que têm sido confiscados, tomados, ocupados, usados ou danificados sem seu consentimento livre, prévio e informado ${ }^{169}$.

$\S 2^{\circ}$ desse artigo, detalha mais modalidades de reparação que são relevantes como a privação de terras, territórios e recursos. Assim, a menos que os povos interessados estabeleçam acordo livremente em contrário, a compensação consistirá em terras, territórios e recursos de igual qualidade, extensão e estatuto legal ou de compensação monetária ou outra reparação adequada.

\footnotetext{
168 ORGANIZAÇÃO DAS NAÇÕES UNIDAS, 2007.

169 ORGANIZAÇÃO DAS NAÇÕES UNIDAS, 2007
} 
Os Estados adotarão medidas eficazes em cooperação com os povos indígenas interessados para combater o preconceito, eliminar a discriminação e promover a tolerância, a compreensão das boas relações entre os povos indígenas e todos os outros setores da sociedade.

O direito à reparação dos povos indígenas inclui aspectos essenciais para tentar garantir e/ou reparar por meio das disposições previstas na Declaração sobre os Direitos dos Povos Indígenas, as injustiças históricas sofridas pelos povos indígenas.

\subsection{A proteção das minorias étnicas e o princípio da isonomia}

Destaca-se a mudança de alcance do ideal de igualdade como um conceituado valor após as Revoluções e da projeção de seus efeitos nas sociedades ocidentais, notadamente a partir dos séculos XIX e XX

A proclamação de que todos são iguais perante a lei só adquire sua verdadeira extensão ou definição quantitativa quando se delimitam quais ou quem são esses "todos" atingidos pela igualdade, afirmação que possui caráter qualitativo ${ }^{170}$ e definidor do termo ou elemento a ser comparado entre os sujeitos.

Nesse sentido, os elementos objetivos necessários para a condição de minoria, baseiam-se na composição de um número inferior de membros em relação ao resto da população do Estado. Enquanto que, o segundo critério, baseia-se na posição não dominante do grupo minoritário, sendo considerado como principal problema na violação dos direitos humanos e no descumprimento do princípio da não discriminação em relação às minorias étnicas.

Assim, a igualdade é um valor relativo que atende ao direito na vida social. Assim, todos os valores se relativizam, já que a igualdade é um conceito que se influencia pela cultura desenvolvida a partir de um contexto na construção social.

É, portanto, um conceito relacional ou uma relação fruto de comparação ${ }^{171}$. $O$ reconhecimento da igualdade e da cidadania relacionado à igualdade de tratamento

\footnotetext{
${ }^{170}$ BOBBIO, 2004. p. 69.

${ }^{171}$ WALZER, Michael. Esferas da justiça: uma defesa do pluralismo e da igualdade. São Paulo: Martins Fontes, 2003. p. 21. O autor afirma que "a igualdade é uma relação complexa de pessoas, mediadas por bens que criamos, compartilhados e dividimos entre nós”.
} 
das diferentes culturas dos grupos étnicos aponta mais para a direção de uma política multicultura do que para um pluralismo cultural ${ }^{172}$.

Para d'Adesky ${ }^{173}$, o pluralismo cultural não engloba, necessariamente, uma igualdade política das diferentes culturas que se encontram num dado território geográfico, ao contrário, o multiculturalismo tende necessariamente a reconhecer a igualdade de valor intrínseco de cada cultura.

Embora d'Adesky diferencie multiculturalismo de pluralismo cultural, Néstor Canclini ${ }^{174}$ demonstra que nas sociedades nacionais latino-americanas, em grande parte, o pluralismo cultural tem sido aceito, até mesmo construindo procedimentos de integração, objetivando a admissão de modos diferentes de organização econômica e representação política.

Ágnes Heller afirma que é "óbvio que a igualdade não é considerada como valor universal independente, mas sim como condição de realização completa e infalível dos valores da vida e da liberdade"175.

No dizer de Paulino Jacques, "não é demais repetir que igualdade não significa uniformidade, mas pressupõe heterogeneidade e pluralidade. A uniformidade é própria do caos; a variedade, da organização"176.

Robert Alexy, após afirmar que nunca duas pessoas ou "situações pessoais vitais" são iguais em todos os aspectos, destaca que a igualdade e a desigualdade só podem dizer respeito a determinadas situações e os juízos sobre a igualdade e desigualdade são relações triádicas, pois envolvem dois sujeitos ou situações e uma propriedade existentes em ambos ${ }^{177}$.

172 LÉON-PORTILLA, Miguel. América Latina: múltiplas culturas, pluralidade de línguas. Revista Tempo Brasileiro: América Latina: vias e desvios, Rio de Janeiro, n. 112-123, 1995. p. 39 : "As áreas abrangem educação e cultura que incluem o acesso ao legado cultural, comunicações que não prejudiquem mas fortaleçam sua identidade, exercício de direitos humanos individuais, sociais e étnicos, justiça e posse da terra".

${ }^{173}$ D'ADESKY, Jacques. Pluralismo étnico e multiculturalismo: racismos e anti-racismos no Brasil. Rio de Janeiro: Pallas, 2001. p. 187.

${ }^{174}$ CANCLINI GARCIA, Néstor. A integração num contexto pluriétnico e pluricultural. Revista Tempo Brasileiro, Rio de Janeiro, n. 122-123, 1995. p. 44.

${ }^{175}$ HELLER, Ágnes. Más allá de la justicia. Barcelona: Crítica, 1999. p. 202.

176 JACQUES, Paulino. Da igualdade perante a lei: fundamento, conceito e conteúdo. 2. ed. Rio de Janeiro: Revista Forense, 1957. p. 228.

177 ALEXY, Robert, Teoria de los derechos fundamentales. Madrid: Centro de Estudios Constitucionales, 1993. p. 386-387. Dessa afirmação o autor extrai a distinção entre igualdade fática parcial e igualdade fática universal do par de comparação. 
Antônio Enrique Pérez Luño observa que a dimensão lógica do conceito de igualdade deve ser capaz de permitir a identificação da igualdade ou da desigualdade ${ }^{178}$.

O autor atribui a diversidade de significados a um valor social fundamental, ao lado da liberdade, do bem comum e da justiça, valores que se dirigem ao desenvolvimento ético-social da comunidade humana. A condição de valor basilar da sociedade e a correlação com outros princípios, associada à diversidade em que a igualdade e o desenvolvimento histórico são inseridos, produzem múltiplos conceitos que serão fundamentos importantes para a construção de direitos do povo devido seu caráter pluriétnico e multicultural.

Celso Antônio Bandeira de Melo ${ }^{179}$ observa que a lógica para reduzir a desigualdade entre as pessoas está atrelada a valores culturais, dependentes do tempo e do espaço. Dessa forma, as pessoas, as coisas e as situações que podem ser entre si comparadas são muitas, sendo essa a dupla razão da inesgotabilidade do conceito de igualdade.

Segundo Paulino Jacques, não se pode negar a existência objetiva do princípio da igualdade perante a lei no Brasil, uma vez que a referida norma, com status constitucional, está presente em todas as Constituições ${ }^{180}$.

Para Celso Antonio Bandeira de Mello, "a lei não deve ser fonte de privilégios e perseguições, mas instrumento regulador da vida social, que necessita tratar equitativamente todos os cidadãos. Esse é o conteúdo político-ideológico absorvido pelo princípio da isonomia e juridicizado pelos textos constitucionais em geral, ou de todo modo assimilado pelos sistemas normativos vigentes"181.

Cármen Lúcia Antunes Rocha, por sua vez, identifica na norma o dever estatal de corrigir as distorções sociais desiguais, ao dizer que:

o princípio da igualdade cumpre uma função determinante para o Poder Público, de transformar, pelo seu vigor impositivo, as condições

\footnotetext{
${ }^{178}$ PÉREZ LUÑO, Antonio Enrique. Dimensiones de la igualdad. 2. ed. Madrid: Dykinson, 2007. p. 18.

179 MELLO, Celso Antonio Bandeira de. Princípio da isonomia: desequiparações proibidas e desequiparações permitidas. Revista Trimestral de Direito Público, n. 1, 1993. p. 82.

180 JACQUES, 1957. p. 221.

${ }^{181}$ MELLO, Celso Antonio Bandeira de. O conteúdo jurídico do princípio da igualdade. 3. ed. São Paulo: Malheiros, 2000. p. 10.
} 
sociais de modo a torná-las mais niveladas no plano socioeconômico para a plena eficácia da norma principiológica ${ }^{182}$.

Na maioria dos estudos sobre a igualdade existem duas dimensões básicas: a igualdade perante a lei e a igualdade na lei.

Celso Antunes Bandeira de Mello ilustra que a Constituição de 1988, ao estabelecer no artigo $5^{\circ}$ que todos são iguais perante a lei, teve interpretação unânime de que, ao fazê-la, não se restringiu apenas em nivelar todos com a lei, ${ }^{183}$ mas perante a lei, impondo um tratamento isonômico e impedindo que sejam criadas discriminações entre os cidadãos em respeito aos preceitos fundamentais do Estado Democrático de Direito.

Hans Kelsen ao descrever a igualdade perante a lei "apenas estabelece o princípio imanente a todo Direito, da juridicidade da aplicação normativa de modo geral e o princípio da legalidade como fundamento de aplicação das leis, ou seja, apenas se estatui que as normas devem ser aplicadas, nada mais se exprime senão o sentido imanente às normas jurídicas"184.

Essa posição é admitida por Celso Antonio Bandeira de Mello ${ }^{185}$, para quem a diferenciação dentre igualdade perante a lei e igualdade na lei existe para separar as obrigações do legislador e do aplicador.

A noção de igualdade perante a lei pode surgir de quatro formas, conforme relata Antonio Enrique Pérez Luño:

a) a igualdade perante a lei aparece de modo geral como a forma de garantir que todos os sujeitos de determinada sociedade estão ou devem estar submetidos às mesmas leis e os mesmos órgãos judiciais. As normas devem ser idênticas para todos, impedindo que se formem grupos de pessoas ou mesmo indivíduos que isoladamente sejam excluídos da aplicação genérica da lei;

\footnotetext{
${ }^{182}$ ROCHA, Cármen Lúcia Antunes. Ação afirmativa: o conteúdo democrático do princípio da igualdade jurídica. Revista de Informação Legislativa, v. 33, n. 131, p. 283-295, jul./set.1996. Disponível em: < http://www2.senado.leg.br/bdsf/item/id/176462>. Acesso: $1^{\circ}$ dez. 2016.

${ }^{183}$ MELLO, 2000. p. 9.

${ }^{184}$ KELSEN, Hans. Teoria pura do direito. Tradução de Baptista Machado. São Paulo: Martins Fontes. 1999. p. 158. Carl Schmitt também destaca que a igualdade é imanente ao conceito da própria lei, própria ao Estado de Direito, de modo que é lei somente aquela que contém em si mesma a possibilidade de igualdade, sendo assim uma norma geral.

${ }^{185}$ MELLO, 2000. p. 16.
} 
b) a igualdade perante a lei pode ainda surgir como exigência de equiparação, que também determina o dever de concessão de igual tratamento para situações em que as diferenças são irrelevantes ${ }^{186}$;

c) a igualdade perante a lei pode surgir como exigência de diferenciação, impondo que se dê tratamento diferenciado para situações ou pessoas que são aparentemente iguais, mas que possuem diferenciações devidamente justificadas na própria lei;

d) a igualdade perante a lei pode ainda manifestar-se como exigência de igualdade procedimental para todos os indivíduos de determinada sociedade. Tratase da igualdade de tratamento pelo processo e no procedimento, seja ele administrativo seja judicial, no qual não se podem estabelecer distinções.

Para Norberto Bobbio, a igualdade perante à lei pode vir expressa de dois modos: "todos são iguais perante a lei" ou "a lei é igual para todos", sendo princípio antigo, que se refere e se reporta necessariamente à isonomia grega ${ }^{187}$.

Jorge Miranda limita a validade da distinção a duas hipóteses: a) quando a igualdade jurídico-formal é igualdade liberal e a material é crítica social e b) quando se separam momentos e planos, um primeiro atributo de direitos e outro de fixação de incumbências estatais ${ }^{188}$.

Manoel Gonçalves Ferreira Filho identifica na igualdade perante a lei três aspectos: o primeiro, de verdadeira igualdade perante o direito, sendo a lei uma só para todos, de forma a abolir a criação de privilégios ou leis especiais vinculadas de uma pessoa ou um grupo especial; o segundo, de uniformidade de tratamento de modo igual, sem poder favorecer ou desfavorecer pessoas determinadas e o terceiro, proibindo discriminações ${ }^{189}$.

Paulo Bonavides declara que a igualdade jurídica do antigo Estado de Direito já não existe mais. A igualdade se transformou na igualdade material da nova forma de Estado, levando em consideração os fatores ideológicos e axiológicos.

\footnotetext{
${ }^{186}$ GARRIDO GOMEZ, Maria Isabel. La igualdad en el contenido y en la aplicación de la ley. 1. ed. Madrid: Dykinson, 2009. p. 165.

${ }^{187}$ BOBBIO, Norberto. Igualdade y libertad. Introducción de Gregorio Peces-Barba. Barcelona: Paidós, 1993. p. 72.

${ }^{188}$ MIRANDA, Jorge. Manual de direito constitucional: direitos fundamentais. 9. ed. Coimbra: 49, 2012. p. 225.

${ }^{189}$ FERREIRA FILHO, Manoel Gonçalves. Estado de direito e constituição. São Paulo: Saraiva, 2012. p. 28.
} 
Luís Roberto Barroso acredita que a ambiguidade na formulação do princípio é conciliável, embora árdua, e se constitui em ponto obrigatório de reflexão para qualquer análise científica do tema ${ }^{190}$.

Dessa forma, a igualdade formal é costumeiramente identificada como a exigência jurídico-política sintetizada no princípio da igualdade perante a lei, sendo comum dizer que igual perante a lei é dizer que se é formalmente igual ${ }^{191}$.

Pela mesma razão se afirma que a igualdade perante a lei se qualifica com um formalismo abstrato ${ }^{192}$, uma vez que considera como iguais a todos, quando sobre eles são estabelecidas normas.

Para Norberto Bobbio, a igualdade de direito significa mais que a mera igualdade perante a lei, mas o meio de exclusão das discriminações não justificadas, isto é, significa gozar igualmente os cidadãos de direitos fundamentais constitucionalmente garantidos.

A diferença entre igualdade perante a lei e igualdade de direito fica sublinhada em algumas formulações, como na Constituição brasileira, quando se diz que os homens são iguais perante a lei e nos direitos, enquanto a igualdade perante a lei é somente uma forma específica e historicamente determinada de igualdade de direito ou dos direitos.

A igualdade de direito compreende além de uma igualdade perante a lei. "É a consolidação de todos os direitos fundamentais enumerados em uma Constituição, como os direitos civis e políticos proclamados nas Constituições modernas"193.

José Afonso da Silva nega a diferenciação, admitida, que revela a existência de uma dupla dimensão da igualdade no Direito Constitucional brasileiro, por ver desvantagem na cisão da igualdade e por identificar na igualdade perante a lei, o dever tanto para quem cria a norma como para os seus aplicadores ${ }^{194}$.

Esse princípio cuja observância vincula, incondicionalmente, todas as manifestações do Poder Público deve ser considerado em sua precípua função de

\footnotetext{
${ }^{190}$ BARROSO, Luís Roberto. Igualdade perante a lei. Revista de Direito Público, São Paulo, n. 78, 1986. p. 66.

191 ROTHENBURG, Walter Claudius, Igualdade. In: LEITE, George Salomão; SARLET, Ingo Wolfgang (Coord.). Direitos fundamentais e estado constitucional: estudos em homenagem a J. J. Gomes Canotilho. São Paulo: Revista dos Tribunais. Coimbra, 2009. p. 359-364.

192 COMPARATO, Fabio Konder. Igualdade, desigualdade. Revista Trimestral de Direito Público, n. 1, 1993. p. 69.

193 BOBBIO, 2004. p. 72.

${ }^{194}$ SILVA, José Afonso da. Curso de direito constitucional positivo. São Paulo: Malheiros, 2005. p. 215.
} 
impedir discriminações e de extinguir privilégios, sub duplo aspecto: (a) o da igualdade na lei; e (b) o da igualdade perante a lei.

Nesse sentido, a igualdade na lei que opera numa fase de generalidade puramente abstrata constitui exigência destinada ao legislador que, no processo de sua formação, nela não poderá incluir fatores de descriminação, responsáveis pela ruptura da ordem isonômica.

A igualdade perante a lei, contudo, pressupondo a lei já elaborada, traduz imposição destinada aos demais poderes estatais que, na aplicação da norma, não poderão subordiná-la aos critérios que ensejam tratamento seletivo ou discriminatório.

A igualdade material, substancial ou de fato é nitidamente identificada com a dimensão de igualdade na lei. Pode inicialmente significar a vedação ao aplicador de fazer distinções arbitrárias contidas no texto legal e posteriormente, o dever do aplicador de fazer as correções das desigualdades por meio de seu ato administrativo ou judicial.

A conexão das duas dimensões ocorre por não serem propriamente isoladas, uma vez que a igualdade material pode vir imposta pela igualdade perante a lei, e, quando vem amparada, pela concessão de direitos iguais, de prestações iguais ou de compensações aos mais frágeis, tais direitos são instrumentais ao fim que é a igualdade.

A igualdade social tende a se configurar na medida em que a igualdade jurídica ultrapassa o plano formal e se consolida com efetiva vantagem jurídica aos sujeitos sociais considerados em desvantagem. Nesse sentido, é revelada a insuficiência da simples proclamação de direitos para a efetivação da igualdade.

Ao serem reconhecidas no artigo $3^{\circ}$ da Constituição Federal de $1988^{195}$, de forma inédita, a pobreza, a marginalização e as desigualdades sociais, evidentemente se reconhece também que os destinatários da norma são desiguais e assim devem ser tratadas pelas demais normas constitucionais e infraconstitucionais, cabendo ao Estado, ainda, a erradicação da pobreza e da marginalização, além da proclamada redução das desigualdades sociais ${ }^{196}$.

195 BRASIL. Constituição (1988) Constituição da República Federativa do Brasil de 5 de outubro de 1988. Brasília, DF: Senado Federal. Disponível em: <https://www.planalto.gov.br/ccivil_03/constituicao/ constituicao.htm>. Acesso: 5 dez. 2016.

${ }^{196}$ O objetivo consagra três espécies de desequilíbrios sociais, estabelecendo como finalidade a erradicação de dois deles: a pobreza e a marginalização, mas para as desigualdades sociais prevê somente a redução, sem 
Luís Roberto Barroso indica que, quando se trata da igualdade material, devese caminhar para a construção de processos igualitários que possibilitem o acesso a bens e direitos disponíveis nas sociedades ${ }^{197}$, sem que se pense em uma igualdade absoluta na partilha de todos os bens, mas em condições mínimas de efetivo acesso aos demais bens ${ }^{198}$.

Robert Alexy afirma que, quando se trata da função da igualdade, só se examinam a obrigação e a proibição de se tratar igualmente o reconhecimento desigual, pois a aplicação de regra de justiça não define a obrigação estatal de criar a igualdade fática ${ }^{199}$.

Entende-se por 'igualdade de fato' a igualdade em relação aos bens materiais e econômicos, distinta da igualdade formal ou jurídica e da igualdade de oportunidade ou social. Essa clareza conceitual não define com exatidão quando, em relação as quais bens e como se deve obter essa igualdade de fato 200.

Direitos fundamentais são faculdades e instituições que, em seu conjunto, em dado momento, concretizam as exigências da dignidade, da liberdade e da igualdade dos homens, de modo a serem reconhecidas e consagradas nas leis.

Os direitos humanos fundamentais têm relação direta com a garantia de que o Estado não deve interferir no âmbito individual e com a valorização da dignidade humana reconhecida universalmente pela maior parte dos Estados, tanto na esfera constitucional quanto na infraconstitucional, no direito consuetudinário, além do reconhecimento por parte dos tratados e convenções internacionais.

Os direitos fundamentais têm, ainda, como características a imprescritibilidade, a inalienabilidade, a irrenunciabilidade, a inviolabilidade, a universalidade, a efetividade, a interdependência e a complementaridade ${ }^{201}$.

Os direitos fundamentais podem ser divididos em categorias ou dimensões geracionais, sendo as de primeira dimensão de caráter individualista, resultado do liberalismo do século XVIII. São direitos de defesa evidenciados pela intervenção do

erradicação, numa clara referência à subsistência e manutenção de "desigualdades toleráveis", constituindo um contraponto ao Estado Democrático de Direito.

${ }^{197}$ BARROSO, 1986. p. 69.

${ }^{198}$ CAMPOS, Francisco. Igualdade de todos perante a lei. Revista Direito Administrativo. Rio de Janeiro: Edição especial, 2013. p. $38-40$.

199 ALEXY, 1993. p. 402.

${ }^{200}$ BOBBIO, 2004. p.192.

${ }^{201}$ MORAES, Alexandre de. Direitos humanos fundamentais. São Paulo: Atlas, 1998. p. 22-23. (Coleção Temas Jurídicos, 3). 
Estado na esfera individual. Sendo considerados direitos fundamentais da primeira dimensão, a princípio, os direitos à vida, à liberdade, à propriedade e à igualdade perante a lei ou igualdade formal ${ }^{202}$.

Por outro lado, os direitos fundamentais de segunda dimensão surgiram no século XIX, dados os sérios problemas sociais e econômicos causados pela industrialização, fruto das doutrinas socialistas e da ineficácia da liberdade e igualdade formal. Por causa disso, exigiu-se, mediante várias reivindicações, que o Estado agisse ativamente para a concretização da justiça social.

Os direitos fundamentais nessa fase são de cunho positivo, pois o que se pretende é propiciar ao individuo os direitos a prestações sociais por parte do Estado como: assistência social, saúde, trabalho e educação, mostrando, com isso, que as liberdades formais abstratas se transformaram em liberdades materiais e concretas, ou seja, as chamadas "liberdades sociais".

Nessa fase, a igualdade cumpre a sua dupla dimensão de direito material de ser igualmente tratado, mas, também, cumpre a função de direito instrumental, direito para os outros direitos. Assim servirá como o direito de ter igualdade no acesso aos direitos fundamentais.

Esses novos direitos fundamentais se consagram significativamente no século $\mathrm{XX}$, mais precisamente nas Constituições do segundo pós-guerra, além de serem tratados em vários pactos internacionais.

Os direitos fundamentais de segunda dimensão surgiram apoiados, também, no princípio da igualdade, mas no sentido da igualdade material. No entanto, assim como os direitos de primeira dimensão, os direitos sociais também se referem ao individuo, não podendo, portanto, ser considerados direitos coletivos ou difusos. Eles podem ser considerados uma "densificação" do princípio da justiça social, além de atenderem às exigências das classes economicamente mais fracas ${ }^{203}$.

Os direitos fundamentais de terceira dimensão, considerados direitos de fraternidade ou de solidariedade, distinguem-se dos anteriores, de natureza individual. Seu objetivo é a proteção de grupos humanos, como a família, o povo e a nação,

${ }^{202}$ HOFFE, Otfried. Justiça política. Tradução de Peter Naumann. Porto Alegre: Martins Fontes, 2001. p. 170171.

${ }^{203}$ SARLET, Ingo Wolfgang. A eficácia dos direitos fundamentais. Porto Alegre: Livraria do Advogado, 2001. p. 55. 
esses direitos tutelam os direitos coletivos ou difusos, tais como meio ambiente e qualidade de vida.

São considerados direitos fundamentais de terceira dimensão os direitos à paz, à autodeterminação dos povos, ao desenvolvimento, à conservação e utilização do patrimônio histórico e cultural. Trata-se das novas imposições fundamentais do ser humano causadas pelos impactos tecnológicos, pelo marcante estado de guerra, pelo processo de descolonização do segundo pós-guerra, fatores que atingiram profundamente o âmbito dos direitos fundamentais. Em relação à sua positivação, esses direitos fundamentais, em sua maioria, não são reconhecidos na esfera do direito constitucional. No entanto, têm sido acolhidos na seara do direito internacional, como se verifica em diversos tratados e outros documentos transnacionais ${ }^{204}$.

O ideal político tem conteúdo preponderantemente programático, de meta a ser alcançada ou postulado a ser preservado, como princípio de justiça social, quando previsto na Constituição e nas leis. J. J. Gomes Canotilho identifica a conexão da igualdade com uma política de justiça social e com a concretização das imposições constitucionais tendentes à efetivação dos direitos econômicos, sociais e culturais ${ }^{205 "}$.

O Preâmbulo da Constituição Federal de $1988^{206}$ descreve fatores que instituem garantias fundamentais no Estado Democrático, destinado a assegurar a igualdade e a justiça como valores supremos de uma sociedade fraterna, pluralista e sem preconceitos, estabelecendo objetivos, metas ou ideais a serem alcançados pela nova forma de Estado. Assim, a política, como forma de organização dos assuntos públicos e de interesse coletivo, reflete as duas dimensões da igualdade, formal e material.

Essa definição de conexidade entre direito e moral deve ser precedente à identificação da igualdade como valor, observada a realidade constitucional brasileira. No caso em exame, há estrita identificação, pois no Preâmbulo da Constituição Federal a igualdade é arrolada como um valor, supremo, ao lado de direitos sociais e individuais, da liberdade, da segurança, do bem-estar, do desenvolvimento e da justiça 207 .

\footnotetext{
${ }^{204}$ SARLET, 2001. p. 57.

${ }^{205}$ CANOTILHO, J. J. Gomes. Direito constitucional e teoria da Constituição. Coimbra: Almedina, 1999. p. 430. 206 BRASIL, 1988.

207 "Nós, representante do povo brasileiro, reunido em Assembleia Nacional Constituinte para instituir um Estado Democrático, destinado a assegurar o exercício dos direitos sociais e individuais, a liberdade, a segurança, o bem-estar, o desenvolvimento, a igualdade e a justiça como valores supremos de uma sociedade fraterna,
} 
A conexão entre direito e moral deve ser precedente à identificação da igualdade como um valor, observada a realidade constitucional brasileira. No caso em exame, há estrita identificação, pois no Preâmbulo da Constituição Federal a igualdade é arrolada como um valor supremo, ao lado de direitos sociais e individuais, da liberdade, da segurança, do bem-estar, do desenvolvimento e da justiça.

Além disso, o artigo 3ำ da Constituição Federal do Brasil ${ }^{208}$ estabelece como objetivos fundamentais: construir uma sociedade livre, justa e solidária; erradicar a pobreza e a marginalização e reduzir as desigualdades sociais e promover o bem de todos, sem preconceitos de origem, raça, sexo, cor, idade e quaisquer outras formas de discriminação.

Norberto Bobbio, como positivista, afirma que a justiça apareceu como um termo axiologicamente significante, ao passo que a igualdade aparece como um termo neutro, embora no debate político a igualdade seja considerada um dos valores fundamentais das filosofias e ideologias políticas ${ }^{209}$.

Maria Falcon Tella aponta três modos de aplicar a igualdade: tratamento igualitário, tratamento proporcional e tratamento equitativo. O primeiro considera merecido o trato igual aos iguais; o segundo ocorre quando o trato é desigual aos desiguais, na proporção das desigualdades, sendo ambos quantitativos e numéricos; ao passo que o último, tratamento equitativo, se ampara em valores e não em quantidades ou medidas ${ }^{210}$.

John Rawls, ao tratar da justiça como equidade e do princípio da justiça, sobrevaloriza as liberdades políticas dadas a todos os cidadãos. Seja qual for a posição econômica ou social deles, têm de ser suficientemente iguais de modo que todos tenham uma oportunidade equitativa de ocupar cargos públicos, de influenciar as eleições, dentre outras liberdades ${ }^{211}$.

A solidariedade relacionada ao princípio da igualdade pode vir identificada com a humanidade e a emergência de uma ideologia solidarista, associada à comunidade internacional, composta por nações e povos que coexistem e entre si se

pluralista e sem preconceito, fundada na harmonia social e comprometida, na ordem interna e internacional, com a solução pacífica das controvérsias, promulgamos, sob a proteção de Deus, a seguinte Constituição da República Federativa do Brasil” (BRASIL, 1988).

${ }^{208}$ BRASIL, 1988.

${ }^{209}$ BOBBIO, 1993. p. 67.

${ }^{210}$ FALCÓN Y TELLA, María José. Equidad, derecho y justicia. Madrid: Universitaria Ramón Areces, 2005. p. 267-270.

${ }^{211}$ RAWLS, John. Justiça como equidade: uma reformulação. São Paulo: Martins Fontes, 2003. p. 211. 
respeitam, buscam valores e direitos comuns, preservam interesses e bens de todos. Essas ideias estão nitidamente identificadas a um universalismo e à igualdade entre as pessoas e entre as nações ou povos.

Nesse sentido, a solidariedade se identifica, também, com os direitos fundamentais, dentre os quais se situam a igualdade e a liberdade, como descreve Ricardo Lobo Torres, servindo de fundamento aos direitos difusos, também conhecido como "direitos de solidariedade" que estão associados à liberdade e à justiça social, à igualdade, ao universalismo e mesmo ao nacionalismo, aos direitos fundamentais, sociais e econômicos característicos desta "era de direitos"212.

Portanto, a solidariedade pode ser vista como um aspecto essencial dos direitos fundamentais e se integra com os demais valores como: liberdade, segurança jurídica e igualdade, pelo objetivo comum de contribuir.

É por meio dos direitos que fundamentam o dinamismo da liberdade que se facilita o exercício do direito de escolha em vista da conservação da liberdade ou autonomia moral, contribuindo para a criação de uma ampla comunicação social, reforçando a ideia de que um projeto moral deve ser elevado a lei geral, permitindo que a solidariedade seja sinônimo de igualdade para garantia de preceitos fundamentais no Estado democrático de direito.

212 TORRES, Ricardo Lobo. A cidadania multidimensional da era dos direitos: teoria dos direitos fundamentais. Rio de Janeiro: Renovar, 1999. p. 262. 


\section{O PLURALISMO ETNO-JURÍDICO COMO POSSIBILIDADE PARA A AUTODETERMINAÇÃO DOS POVOS INDÍGENAS}

O aspecto do pluralismo jurídico na questão indígena é uma marca da democracia contemporânea, não possuindo um único significado.

Assim, o pluralismo pode ser compreendido como uma descrição das concepções individuais em relação a dignidade da vida ou em forma de assinalar a multiplicidade de identidades sociais culturalmente específicas, devido as peculiaridades atribuídas ao seu processo histórico de desenvolvimento cultural.

Para Sabadell1313 a primeira concepção evidencia as análises teóricas da "interlegalidade" em que ocorre a identificação dos diversos sistemas de normas jurídicas interagindo entre si para a construção de uma rede, que assegure os direitos pluriétnicos e multiculturais.

A segunda concepção de pluralismo ilustra uma coexistência entre normas jurídicas nacionais e internacionais, reivindicado por organizações internacionais como a ONU.

E a terceira concepção, consiste no direito consuetudinário e nas pesquisas empíricas desenvolvidas por instituições sociais como igrejas, sindicatos e associações civis.

Nesse sentido, existe uma corrente doutrinária que é a crítico-deliberativa, a qual define o pluralismo jurídico como uma concepção capaz de justificar um ideal de justiça, levando em consideração os fundamentos da Constituição Federal e da atuação do poder judiciário para a preservação das diferenças na sociedade democrática.

E o avanço do ordenamento jurídico para assegurar os direitos dos povos indígenas, está em expansão cada vez na sociedade contemporânea, conforme se pode observar no quadro evolutivo que descreve a ampliação do trabalho da ONU para a construção e efetivação dos direitos pluriétnicos e multiculturais, que resguardam os direitos indígenas.

${ }^{213}$ SABADELL, Ana Lúcia. Manual de Sociologia Jurídica: Introdução a uma leitura externa do Direito. São Paulo: Revista dos Tribunais, 2000. p. 12. 
Quadro 1 - Evolução histórica dos direitos dos povos indígenas na Organização das Nações Unidas (ONU).

\begin{tabular}{|c|l|}
\hline \multicolumn{1}{|c|}{ ANO } & \multicolumn{1}{|c|}{ ACONTECIMENTO HISTÓRICO } \\
\hline $1923-1925$ & Primeiro envolvimento internacional \\
\hline $\mathbf{1 9 8 1}$ & Estudos de Martínez Cobo \\
\hline $\mathbf{1 9 8 2}$ & Grupo de Trabalho sobre Populações Indígenas \\
\hline $\mathbf{1 9 8 9}$ & $\begin{array}{l}\text { Organização Internacional do Trabalho (OIT), Convenção } \\
169\end{array}$ \\
\hline $\mathbf{1 9 9 3}$ & Ano Internacional dos Povos Indígenas do Mundo \\
\hline $\mathbf{1 9 9 4}$ & Década Internacional dos Povos Indígenas do Mundo \\
\hline $\mathbf{2 0 0 0}$ & Fórum Permanente sobre Questões Indígenas \\
\hline $\mathbf{2 0 0 1}$ & $\begin{array}{l}\text { Relatório Especial sobre os Direitos dos Povos Indígenas } \\
\text { Segunda Década Internacional dos Povos Indígenas do } \\
\text { Mundo }\end{array}$ \\
\hline $\mathbf{2 0 0 7}$ & $\begin{array}{l}\text { Composição de especialistas sobre direitos dos povos } \\
\text { indígenas } \\
\text { Declaração da ONU sobre os Direitos dos Povos } \\
\text { Indígenas }\end{array}$ \\
\hline $\mathbf{2 0 1 4}$ & \begin{tabular}{l} 
Conferência Mundial sobre os Povos Indígenas \\
\hline
\end{tabular} \\
\hline
\end{tabular}

Fonte: Elaborado pela autora, 2017.

Dessa forma, o reconhecimento interétnico e multicultural contribuirá essencialmente não para que a igualdade estabelecesse uma assimilação das identidades, mas sim a construção e consolidação dos direitos para a garantia das diferenças.

Portanto, assegurar o direito à diferença em uma sociedade pluriétnica, requer políticas públicas eficientes que garantam os interesses sociais, políticos, econômicos e culturais de um povo historicamente marginalizado.

\subsection{0 multiculturalismo no Brasil e suas perspectivas étnicas}

O multiculturalismo é um dos debates culturais mais relevante que acomoda a diversidade humana como enriquecedora para o reconhecimento da pluralidade étnica e multicultural. 
No preâmbulo da Constituição Federativa do Brasil de 1988, observa-se no art. 1, inciso $\mathrm{V}$ que o pluralismo é uma tentativa de preservação das identidades e serve como fundamento para o respeito da diferença étnica e multicultural no Estado democrático de direito, assim como à autodeterminação dos povos, que consiste no relevante princípio de norteia as relações internacionais do Brasil, conforme preceitua 0 art. 4ํㅜㄹ inciso III da Carta Magna.

Observa-se também em seu art. $5^{\circ}$ caput "o direito da igualdade de todos perante a lei, sem distinção de qualquer natureza", porém as constituições brasileiras desde o período imperial descrevem essa igualdade baseada no aspecto formal, visando garantir os direitos fundamentais do cidadão.

No entanto, o aspecto material da igualdade ainda não oferece ao sistema jurídico brasileiro mecanismos eficientes para dirimir os conflitos pautados na diferença cultural entre povos, como relevante fundamento para garantia dos direitos indígenas e não-indígenas ${ }^{214}$.

Por isso, o etnocentrismo jurídico típico dos Estados modernos de origem colonial preponderou sobre o pluralismo jurídico, que de acordo com o entendimento de Wolkmer ${ }^{215}$, consiste na multiplicidade de práticas jurídicas existentes no mesmo espaço sócio-político, interagidas por conflitos ou consensos, podendo ser ou não oficiais e tendo sua razão de ser nas necessidades existenciais, materiais e culturais.

A interação dessas diferenças é importante para a afirmação das reivindicações de autores sociais historicamente marginalizados, como as populações indígenas, abrindo espaço para se repensar como houvera sido realizado o processo histórico de participação e construção social eminentemente excludente em relação a esses agentes de desenvolvimento cultural.

Luigi Ferrajoli216 propõe uma nova sistematização conceitual após admitir que a contraposição entre igualdade e diferença está amparada na "igualdade jurídica". Sendo que, o autor descreve quatro modelos para a configuração da diferença:

1) indiferença jurídica com a diferença;

2) diferenciação jurídica das diferenças;

\footnotetext{
${ }^{214}$ BARBOSA, Marco Antonio. Direito Antropológico e terras indígenas no Brasil. São Paulo: Plêiade: FAPESP, 2001. p.31.

${ }^{215}$ WOLKMER, Antonio Carlos. Pluralismo jurídico: Fundamentos de uma nova cultura no Direito. São Paulo: Ômega, 1994. p. 157-158.

${ }^{216}$ FERRAJOLI, Luigi. Derechos y garantias: la ley del más débil. Madrid: Trotta, 2004. p.73-76.
} 
3) homologação jurídica das diferenças;

4) valorização jurídica das diferenças.

Sendo que o último modelo, valoriza a diferença quando a Constituição de cada Estado soberano, assegura os direitos fundamentais aos grupos especialmente protegidos como: mulheres, crianças, adolescentes, idosos e indígenas.

Esse entendimento é fundamental para a sistematização e valorização das diferenças pluriétnicas e multiculturais, que gradativamente vêm sendo incorporadas ao ordenamento jurídico com o advento da Constituição Federativa do Brasil de 1988, produzindo efeitos sobre as normas jurídicas internas e internacionais, além de contribuir para a garantia dos direitos das minorias étnicas.

Nesse sentido, o multiculturalismo pode ser considerado como o reconhecimento da diferença, pois é através da identidade que o reconhecimento cultural é construído.

Portanto, a noção contemporânea de multiculturalismo de acordo com os ensinamentos de Charles Taylor ${ }^{217}$ está relacionada a política de reconhecimento e à exigência de reconhecimento, porque a identidade é construída parcialmente pela existência ou inexistência de reconhecimento, podendo uma pessoa ou grupo de pessoas ser prejudicado quando aqueles que o rodeiam refletirem uma imagem limitada, inferior ou de desprezo por eles mesmos.

Sendo assim, o multiculturalismo visa o reconhecimento das diferenças pela afirmação da igual dignidade de todas as pessoas, de grupos e culturas, integrantes dessa desigualdade. E que no Estado democrático de direito não se vislumbra utopicamente a igualdade de todas as pessoas ou de que todos tenham os mesmos direitos, porém objetiva-se construir e promover um relevante debate social de um repensar de políticas afirmativas e inclusão social, que colabore efetivamente para a inserção dos agentes de desenvolvimento social marginalizados durante o processo histórico da humanidade.

Então, preservar as identidades e diferenças como reflexo de sua igual dignidade, ainda que não sejam iguais, conforme podemos observar nas comunidades indígenas pelo mundo em suas mais variadas composições culturais e étnicas, os quais visam a preservação de sua cultura peculiar, arte, ritos, crenças e danças que o identificam o pertencimento a um grupo étnico específico, que em muitos casos

217 TAYLOR, Charles. A política de reconhecimento. Multiculturalismo: examinando a política de reconhecimento. Lisboa: Piaget, 1998. p. 45. 
preservam simbolicamente a cultura de seus ancestrais e resistem a um processo marginal de desenvolvimento cultural no mundo da globalização.

Portanto, um processo unificador requerido pela representação de grupos tenderia congelar relações fluidas numa identidade unificada, o que pode recriar, ou seja, reproduzir exclusões opressivas ${ }^{218}$, os quais já são nítidos no processo de desenvolvimento capitalista.

Então, construir uma interpretação adequada da justiça não é somente analisar como parâmetro o paradigma da distribuição para mitigar as desigualdades das minorias étnicas historicamente construídas ao longo do tempo, mas repensar as políticas afirmativas de inclusão social desenvolvidas pelo Estado para ampliar o reconhecimento e as reivindicações de uma identidade social diferenciada.

Desenvolver uma valorização da diversidade cultural é um mecanismo de contraposição aos mecanismos de assimilação cultural enraizados ao longo do processo de desenvolvimento cultural das minorias étnicas no Brasil. E promover a diferença cultural como uma luta para se alcançar uma democracia mais inclusiva é um dos grandes fundamentos dos direitos coletivos, os quais almejam as populações indígenas no Estado democrático para a idoneidade de um diálogo intercultural que valorize suas diferentes culturas.

E nesse sentido, a democracia introduziu a política de reconhecimento igualitário que tem assumido diversas formas ao longo dos anos, haja vista que a noção contemporânea de identidade permitiu o surgimento da política da diferença, baseada no reconhecimento.

Existem dois níveis de imprescindíveis de reconhecimento que são:

1) O íntimo, que caracteriza-se pela autodescoberta e autoafirmação de características individuais para a formação da identidade interior;

2) E o social, que ocorre quando a identidade se forma pelo diálogo aberto identificando o outro como um igual e não sob a distinção de inferioridade ${ }^{219}$.

\footnotetext{
218 YOUNG, Iris Marion. Representação política, identidade e minorias, p.142, Lua Nova, São Paulo, 2006. Disponível em: <http://www.scielo.br/pdf/ln/n67/a06n67.pdf〉. Acesso em: 02 maio 2017.

${ }^{219}$ TAYLOR, Charles. A política de reconhecimento. Multiculturalismo: examinando a política de reconhecimento. Lisboa: Piaget, 1998. p. 56-57.
} 
Portanto, o reconhecimento de identidade cultural das populações indígenas com suas especificidades étnicas no Estado pluralista, amplia-se no mundo moderno para que a sociedade multicultural o reconheça como tal, promovendo e fomentando políticas públicas de afirmação para as minorias étnicas, como já se observa nas Universidades Públicas Federais, através da implementação de cotas para negros e indígenas.

Essa política de inclusão educacional através de cotas etno-raciais, evidencia gradativos avanços na implementação de igual respeito às culturas e povos tradicionais que foram marginalizados no processo de desenvolvimento social.

Portanto, buscar os diversos valores culturais no seio da sociedade moderna visando a coexistência de formas culturais diferenciadas contribuem para a consolidação do pluralismo jurídico, considerado relevante fundamento para o consenso da heterogeneidade, do conflito social e da diferença.

Tais considerações encontram fundamento no Preâmbulo da Constituição Federal Brasileira que institui o Estado democrático de direito, assegurando direitos sociais e individuais, buscando a igualdade e a justiça em uma sociedade fraterna e pluralista.

Consubstanciado nos preceitos fundamentais da Carta Magna, a cidadania

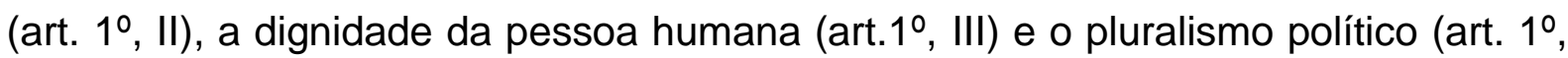
V) são imprescindíveis para a construção e consolidação de uma sociedade livre, justa e solidária nos termos do art. $3^{\circ}$ inciso I, cujo o entendimento de Jacques Maritain ${ }^{220}$ na Obra "Los derechos del hombre y la ley natural", aponta que uma sociedade de homens livres é um relevante fundamento para a consolidação do pluralismo.

Dessa maneira, a concepção multicultural contribui para $\circ$ tratamento adequado aos indivíduos considerados diferentes em suas diversas perspectivas antropológicas e sociológicas, que contribuem significativamente para a manutenção das matrizes culturais de seus antepassados, como os povos indígenas, em sua maioria excluídos do processo de desenvolvimento histórico da Nação. Fato que não implicaria numa assimilação, mas na preservação e respeito à diferença das minorias étnicas historicamente marginalizadas.

${ }^{220}$ MARITAIN, Jacques. Los derechos del hombre y la ley natural: Cristianismo y democracia. Madrid: Palabra, 2001. p. 27. 
Observa-se então no ordenamento jurídico uma mudança de paradigmas, onde o multiculturalismo abre espaço para um direito que contempla potencialmente o discurso dos reprimidos, ampliando o espaço para as normas mais locais que complementam o ordenamento jurídico oficial, formal e centralizado na abstração, generalidade e universalidade, típico do direito soberano.

Esse entendimento promove ambivalências no ordenamento jurídico à medida que, o formal e o informal devem conciliarem-se para a promoção de direitos fundamentais das minorias étnicas, estabelecendo um sistema normativo peculiar decorrente de regras jurídicas ou de regras sociais próprias, quando concebe as populações indígenas ou qualquer outra minoria, seja nacional, étnica ou religiosa, não como um entrave ao desenvolvimento de Estado soberano, mas como um agente de desenvolvimento social capaz de promover e/ou construir políticas de inclusão social eficientes, para mitigar a desigualdade e o processo histórico excludente os quais essas populações foram submetidas.

Por isso, realizar mobilizações sociais nacionais e internacionais para assegurar os direitos indígenas, historicamente relegados a segundo plano na construção dos ideais humanistas é imprescindível para a garantia do direito dos povos, principal fundamento utilizado pelos grupos e organizações internacionais para a defesa dos direitos humanos e consolidação dos ideais de autodeterminação dessas minorias étnicas.

Sendo assim, todas as definições de multiculturalismo, pluralismo e diferença ampliam a concepção contemporânea de igualdade, não apenas como uma compensação da desigualdade e da subordinação daqueles que estiveram à margem do processo de desenvolvimento social, mas como mitigação e respeito das diferenças entre os grupos marginalizados, oprimidos e explorados, seja por razões naturais, sociais ou culturais ${ }^{221}$.

O multiculturalismo no Brasil abre espaço para um diálogo intercultural capaz de mitigar muitos conflitos, pois demonstra uma proposta progressista que inclui a voz e diversos pontos de vista das minorias étnicas historicamente marginalizadas. Assim, o multiculturalismo abrirá novas visões que possuem objetivos precípuos de convergir

221 DOBROWOLSKI, Samantha Chantal. A construção social do sentido da Constituição na democracia contemporânea: entre a soberania popular e direitos humanos. Rio de Janeiro: Lumen Juris, 2007. p. 235 250 . 
a diferença de diversos signos culturais, para um significado que aglutina a emancipação e a inclusão social através de um diálogo intercultural.

Esse imperativo intercultural promove um aspecto redistributivo ao incidir sobre a igualdade e a desigualdade de recursos, para que as diferentes minorias possuam os mesmos direitos e igualdade de oportunidades da maioria.

Além disso, o fomento da interculturalidade é um resultado importante do multiculturalismo, para a realização da inclusão democrática e plural das diferenças étnicas.

\subsection{Pluralismo etno-jurídico e a interculturalidade indígena}

Considerando que a Nação é o conjunto de povos que compõem o Estado, torna-se necessário um levantamento etnonacional que permita uma visualização de natureza antropológica do Estado.

Para isso, cada Estado multiétnico deve conhecer sua própria constituição humana, tornando esse fato de domínio público para toda a sociedade nacional que reconheça a diversidade dos povos existentes nas fronteiras de seu Estado.

Após esse primeiro momento, torna-se imperioso o desenvolvimento de uma educação voltada para tolerância, bem como a evolução desse processo, a constituição de espaços políticos internos, onde cada povo possa, nos limites do seu vínculo jurídico e político com a Nação que o integra, preservar seus costumes, suas crenças, tradições e línguas, ou seja, a autonomia tão defendida pelos povos indígenas ${ }^{222}$.

Saliente-se que a autonomia torna-se sustentável à medida que a tolerância incorpora-se na cultura nacional, estabelecendo os diálogos interétnicos necessários à organização de um Estado pluralista. Com base no desenvolvimento de uma cultura de tolerância, por meio dos processos comunicativos, é possível a constituição de espaços políticos próprios, em harmonia com o todo que o reveste.

STAVENHAGEN, Rodolfo. Etnodesenvolvimento: uma dimensão ignorada no pensamento desenvolvimentista. Anuário Antropológico, Rio de Janeiro: Tempo Brasileiro, n. 84, 1985. p. 30. 
Nos apontamentos de Miguel Bartolomé223, contudo, registra-se que apesar de o diálogo ser um dos elementos fundamentais de qualquer relação humana ele se encontra ausente no processo interétnico. No lugar de diálogo tem ocorrido um monólogo pronunciado pelas sociedades dominantes por meio de seus ideólogos e de suas instituições, ou seja, a não participação real das minorias nos processos decisórios é uma forma de dominação e intolerância.

Historicamente, a imposição cultural e a exclusão de minorias estiveram constantemente na evolução histórica de cada país. No Brasil, pode ser observado quando Colombo, ao chegar à América, por acreditar que estaria nas índias, classificou indistintamente todos os habitantes do Continente Americano de "índios", e essa nomenclatura perdura até hoje.

Inicialmente não houve nenhuma percepção da diferença etnocultural dos povos americanos, pois a única coisa que havia em comum entre eles era não serem europeus.

Ainda hoje no Brasil existe dificuldade em definir o que é ser índio. São utilizados vários critérios: o racial, o cultural e o antropológico, que priorizam a autoidentificação étnica ${ }^{224}$.

Segundo o Estatuto do Índio 225 , o termo "índio" significa "todo indivíduo de origem e ascendência pré-colombiana que se identifica e é identificado como pertencente a um grupo étnico cujas características culturais o distinguem da sociedade nacional"226.

Manuela da Cunha considera que não é visível o Estatuto do Índio definir "índio" antes de definir "comunidade indígena", pois somente a última poderá decidir quem é seu integrante. Para a autora, a melhor definição seria:

Comunidades indígenas são aquelas que se consideram segmentos distintos da sociedade nacional em virtude da consciência de sua continuidade histórica com sociedades pré-colombianas e índio é aquele que 'se considera pertencente a uma dessas comunidades e é por ela reconhecido como membro ${ }^{227}$.

\footnotetext{
${ }^{223}$ BARTOLOMÉ, Miguel Alberto. Processos civilizatórios, pluralismo cultural y autonomias étnicas en América Latina. In: BARTOLOMÉ, Miguel A.; BARABAS, Alícia M. (Coord.). Autonomias étnicas y Estados nacionais. México: Instituto Nacional de Antropologia e História, 1998. p.188.

${ }^{224}$ CUNHA, Manuela Carneiro da. Os direitos do índio: ensaios e documentos. São Paulo: Brasiliense, 1987. p. 25.

225 BRASIL. Ministério da Justiça. Estatuto dos povos indígenas. Brasília, 5 jun. 2009. Disponível em: <www.funai.gov.br/index.php/cnpi1/estatuto-do-indio>. Acesso em: 4 dez. 2016.

${ }^{226}$ BRASIL. Lei n. 6.001, de 17 de dezembro de 1973. Dispõe sobre o Estatuto do Índio. In: LEGISLAÇÃO indigenista. Brasília, DF: Senado Federal: Subsecretaria de Edições Técnicas, 1993. p. 71.

${ }^{227}$ CUNHA, 1987, p. 25-26.
} 
Os primeiros contatos entre os portugueses e os indígenas foram amistosos. A partir de 1530, quando os portugueses decidiram colonizar o Brasil, houve uma profunda modificação nas suas relações e a necessidade da criação de uma legislação indígena.

Pelo sistema de capitanias hereditárias o governo português transferia a autoridade a particulares que tinham pleno direito de escravizar os índios, afugentálos ou exterminá-los.

A missionarização por diversas ordens religiosas, a partir do século $\mathrm{XVI}$, foi uma das primeiras formas de tutela sobre os índios aldeados, adequando "a população indígena às necessidades político-econômicas da colonização portuguesa"228.

Assim, coexistiam no território da América índios aldeados, aliados dos portugueses e índios inimigos, escravizados ou dispersos. A legitimação da escravidão indígena era a chamada guerra justa, com objetivos de "salvar" as almas, erradicar a antropologia, assim como resgatar os cativos capturados por outros índios.

Sob a influência da política integracionista do Marquês de Pombal, que objetivava amenizar a violência praticada contra os indígenas e propiciar sua integração cultural na sociedade, houve a edição do Alvará de 4 de abril de $1755^{229}$, que igualava os direitos dos colonos e dos indígenas referentes ao trabalho, fomentando o casamento inter-racial e proibia à utilização das línguas nativas, tornando o português a língua oficial e marginalizando os traços culturais originários dessas populações.

Por outro lado, a Carta Régia de 1808 induzia a violência sobre as populações indígenas e autorizava a escravidão por quinze anos dos índios capturados.

Com a proclamação da independência do Brasil, em 1822, sob a influência dos ideais liberais, estabeleceu-se uma política indigenista, defendendo o término da escravidão, surgindo uma nova "raça brasileira", por meio da integração e da miscigenação.

\footnotetext{
${ }^{228}$ CUNHA, 1987 , p. $25-2$

229 ALVARÁ de 4 de abril de 1755. Disponível em: http://www.nacaomestica.org/alvara_regio_04_abril_1755_cabouclos.htm>. Acesso em: 30 abr. 2017.
} 
A Constituição de 1824, porém não mencionava a existência de índios no território brasileiro tampouco propunha regular as relações conflituosas entre os índios e os não índios. Em 1831, foi revogada a Carta Régia que declarava a guerra oficial aos indígenas e sua escravidão.

Assim, em 1845, a única norma indigenista do governo imperial era o Regulamento das Missões, representando mais um documento administrativo do que um plano político. Esse regulamento tentou oferecer uma carta proteção às populações indígenas, diminuindo a ação armada do Estado, promovendo a integração por meio da descaracterização cultural, mas o objetivo principal era acabar com os conflitos nas áreas de expansão da sociedade não indígena, retirando os indígenas das terras concentrando-os em aldeias.

A situação se agravou com o incentivo da colonização europeia. A lei de terra trouxe nova concepção da propriedade da terra, acessível apenas pela compra e pela aquisição do título de propriedade e não mais pela posse, fazendo com que os indígenas fossem expropriados de suas terras, ocupadas paulatinamente por colonos e atividades extrativistas e agropastoris.

O Código Civil de 1916 mantém com outras características o regime tutelar e classifica o indígena de relativamente incapaz, como se pode observar que são incapazes, relativamente a certos atos (art. 147, I) ou à maneira de os exercer: I - os maiores de 16 (dezesseis) e os menores de 21(vinte e um) anos (artigos 154 a 156); II - os pródigos; III- os silvícolas. Além do parágrafo único, que estabelece que os silvícolas ficarão ao regime tutelar, estabelecido em leis e regulamentos especiais, o qual cessará à medida que se forem adaptando à civilização do país ${ }^{230}$.

A tutela indígena passou a ser especialmente exercida pelo Poder Executivo, por meio dos órgãos destinados à respectiva função, sendo que o instituto deveria garantir determinados privilégios aos indígenas, porém foi utilizado como forma de coação e limitação de seus direitos, mantendo-se carregado de preconceitos ${ }^{231}$.

\footnotetext{
${ }^{230}$ BRASIL. Presidência da República. Lei n. 3.071, de $1^{\circ}$ de janeiro de 1916. Código civil de 1916. Diário Oficial da União, 5 jan. 1916. Disponível em: <http://www.camara.gov.br/sileg/integras /111025.pdf〉. Acesso em: 20 set. 2016

${ }^{231}$ COLAÇO, Thais Luzia. "Incapacidade” indígena: tutela religiosa e violação do direito guarani nas missões jesuíticas. Curitiba: Juruá, 2000. p. 9.
} 
Pela primeira vez, em $1934^{232}$, os indígenas foram citados na Constituição, sendo estabelecida a competência da União para legislar sobre a integração do índio à comunidade nacional. Também ficou garantida a posse da terra onde os "silvícolas" se achavam localizados e proibiu-se a sua alienação.

A Carta Constitucional outorgada em $1937^{233}$ retirou o item relativo à integração indígena, e com relação à posse da terra se manteve igual à anterior.

A Constituição promulgada em $1946^{234}$ atribuiu a competência da União para legislar sobre a incorporação dos indígenas à comunidade nacional e também tratou do direito à posse da terra.

O Projeto Constitucional de 1967 define a terra como um "patrimônio indígena" que não pode ser alienado, garantindo os direitos de usufruto sobre seus recursos naturais.

A Carta Constitucional promulgada em $1967^{235}$ também tratou das questões anteriores e autorizou o direito ao usufruto dos recursos naturais das terras indígenas e todas as suas utilidades.

O Governo Federal criou, em 1967, a Fundação Nacional do Índio (FUNAI), em substituição ao Serviço de Proteção ao Índio (SPI), com as seguintes diretrizes:

Respeitar à pessoa, às instituições e às comunidades indígenas; preservação da cultura e do equilíbrio biológico do índio; garantia da aculturação espontânea, evitando-se transformações abruptas na sua evolução socioeconômica, exclusividade de usufruto dos seus recursos naturais ${ }^{236}$.

A Constituição outorgada em 1969²37, chamada Ato Institucional n. 1, trouxe algumas modificações com relação à matéria:

Artigo 4. Incluem-se entre os bens da União: IV - As terras ocupadas pelos silvícolas.

${ }^{232}$ BRASIL. Constituição (1934). Constituição da República dos Estados Unidos do Brasil, 1934. Disponível em: <http://www.planalto.gov.br/ccivil_03/constituicao/constituicao34.htm>. Acesso em: 30 abr. 2017.

233 BRASIL. Constituição (1937). Constituição dos Estados Unidos do Brasil, 1937. Disponível em: <https://www.planalto.gov.br/ccivil_03/constituicao/constituicao37.htm>. Acesso em: 30 abr. 2017.

234 BRASIL. Constituição (1946). Constituição dos Estados Unidos do Brasil, 1946. Disponível em: <https://www.planalto.gov.br/ccivil_03/constituicao/constituicao46.htm>. Acesso em: 30 abr. 2017.

235 BRASIL. Constituição (1967). Constituição da República Federativa do Brasil, 1967. Disponível em: <http://www.planalto.gov.br/ccivil_03/constituicao/constituicao67.htm>. Acesso em: 30 abr. 2017.

236 BRASIL. Presidência da República. Lei n. 5.371, de 5 de dezembro de 1967. Autoriza a instituição da "Fundação Nacional do Índio" e dá outras providências. Diário Oficial da União, Brasília, 6 dez. 1967. Disponível em: <http://www.planalto.gov.br/ccivil_03/leis/1950-1969/L5371.htm>. Acesso em: 30 abr. 2017.

${ }^{237}$ BRASIL. Constituição (1969) Emenda constitucional n. 1, de 17 de outubro de 1969. Edita o novo texto da Constituição Federal de 24 de janeiro de 1967. Diário Oficial da União, Brasília, 20 out. 1969. Disponível em: <http://www.planalto.gov.br/ccivil_03/Constituicao/Emendas/Emc_anterior1988/emc01-69.htm>. Acesso em: 15 abr. 2017. 
Artigo 8․ Compete à União:

XVIII - legislar sobre:

o) nacionalidade, cidadania e naturalização; incorporação dos silvícolas à comunhão nacional.

Artigo 198. As terras habitadas pelos silvícolas são inalienáveis nos termos que a lei federal determinar, a eles cabendo a sua posse permanente e ficando reconhecido o seu direito de usufruto exclusivo das riquezas naturais e de todas as utilidades nelas existentes.

$\S 1^{\circ}$ Ficam declarados a nulidade e a extinção dos efeitos jurídicos de qualquer natureza que tenha por objetivo o domínio, a posse ou a ocupação de terras habitadas pelos silvícolas.

$\S 2^{\circ}$ A nulidade e extinção de que trata o parágrafo anterior não dão aos ocupantes direito a qualquer ação ou indenização contra a União e a Fundação Nacional dos Índios.

Observa-se, em todas essas Constituições, projetos e emendas, a intenção do governo brasileiro de integrar o indígena à comunidade nacional, aniquilando a cultura indígena e desrespeitando o direito de suas diferenças.

A Lei n. 6.001/73 238 , chamada "Estatuto do Índio", foi elaborada durante o período de governo autoritário no Brasil. A intenção era responder à comunidade internacional sobre as inúmeras denúncias de extermínio de populações indígenas em território nacional.

Apesar de ter alcançado um avanço social, o Estatuto do Índio ainda estava fundamentado nas intenções integracionistas, conforme descrito art. 1ํ: "Esta lei regula a situação jurídica dos índios ou silvícolas e das comunidades indígenas, com os propósitos de preservar a sua cultura e integrá-los, progressivamente e harmoniosamente, à comunidade nacional239".

O objetivo com o Estatuto do Índio era garantir temporariamente direitos às populações indígenas, porém a expansão da visão cultural assimilacionista sobre as raízes pluriétnicas e multiculturais dos índios abriu espaço para que seus valores culturais fossem incorporados gradativamente nos padrões culturais da comunidade nacional.

Darcy Ribeiro 240 classifica os índios por grupos, conforme seu grau de contato com a civilização:

\footnotetext{
238 BRASIL, 1973.

239 BRASIL, 1973.

${ }^{240}$ RIBEIRO, Darcy. O processo civilizatório: etapas da evolução sociocultural. 10. ed. Petrópolis, RJ: Vozes, 1987.
} 
I - Isolados: Quando vivem em grupos desconhecidos ou de que possuem poucos e vagos informes através de contatos eventuais com elementos da comunhão nacional;

II - Em vias de integração: Quando, em contato permanente com grupos estranhos, conservam menor ou maior parte das condições de sua vida nativa, mas aceitam algumas práticas e modos de existência comuns aos mais setores da comunhão nacional, da qual vão necessitando cada vez mais para o próprio sustento;

III - Integrados: Quando incorporados à comunhão nacional e reconhecidos no pleno exercício dos direitos civis, ainda que conservem usos, costumes e tradições características da sua cultura.

Os direitos dos índios foram assegurados pela Constituição de 1988, dada a atuação de movimentos indígenas na luta pela consolidação de seus direitos, os quais fundamentam as relações entre os índios e os não-índios na sociedade nacional.

Uma das novidades é que as perspectivas assimilacionistas e integracionistas das Constituições anteriores foram retiradas do texto constitucional vigente, que, apesar de ser um avanço jurídico para assegurar os direitos indígenas, não significa que foram sanados todos esses fatores socialmente. Isso porque a integração e a consolidação de garantias fundamentais para as minorias exigem a incorporação de outros valores sociais como a eficácia de uma política pública adequada, já que o índio adquire o direito à alteridade, isto é, a sua especificidade etnocultural é respeitada e garantidos seus direitos indígenas.

A Constituição da República Federativa do Brasil de 1988 reconhece aos índios uma organização social e a garantia de seus costumes, línguas, crenças e tradições, cabendo ao Estado assegurar o efetivo exercício desses direitos culturais $^{241}$.

Com relação às terras tradicionalmente ocupadas pelos indígenas ${ }^{242}$ houve mudanças, uma vez que o direito à terra passou a ser considerado um direito originário, inalienável, indisponível e imprescritível e as terras tradicionalmente

\footnotetext{
${ }^{241}$ BRASIL, 1988, art. 231e 215, § $1^{\circ}$.

${ }^{242}$ José Afonso da Silva descreve que "a expressão ocupados tradicionalmente não significa ocupação imemorial, não quer dizer, pois terras imemorialmente ocupadas, ou seja: terras que estariam ocupadas desde épocas remotas que já se perderam na memória e assim, somente estas seriam as terras deles. [...] As expressões tradicionalmente ocupadas e habitadas em caráter permanente revelam a especificidade de modo que cada povo relaciona-se com as terras que habita segundo seus usos, costumes e tradições. Ocorrem assim que há comunidades mais estáveis, outras menos estáveis, e as que têm espaços mais amplos em que se deslocam" (SILVA, José Afonso da. Terras tradicionalmente ocupadas pelos índios: os direitos indígenas e a Constituição. Porto Alegre: Fabris, 1993. p. 47-48).
} 
ocupadas pelos índios tornaram-se bens da União, que deverá demarcá-las para proteção dos Recursos Naturais ${ }^{243}$.

A legitimidade processual dos índios foi constitucionalmente reconhecida, possibilitando que as comunidades e as organizações, juntamente com o Ministério Público, ingressassem em juízo para a defesa dos direitos e interesses indígenas.

Apesar de estarem garantidos os direitos indígenas na Carta Constitucional de 1988, eles só serão efetivados na prática, por isso é necessário a criação de uma legislação complementar regulamentando os dispositivos constitucionais que regem a matéria.

O Projeto de Lei n. 2.057/97244 proposto para garantir a execução da Constituição referente aos direitos indígenas, sugere a revisão da Lei n. 6.001/73, substituindo o nome do Estatuto do Índio para "Estatuto das Sociedades Indígenas".

O projeto trata dos princípios que a lei deve atender, dos conceitos do termo "índios", comunidade e sociedade indígena, da proteção e do respeito à organização social, aos costumes, às línguas, crenças, às tradições e aos direitos originários sobre as terras que tradicionalmente ocupam e todos os bens dos índios, garantindo seu direito de participação nas instâncias de poder.

Aborda também, a garantia do direito de participar em todas as instâncias de defesa de seus interesses e determina à União a proteção e execução da política de assistência aos índios, podendo receber colaboração dos Estados e Municípios.

Aparentemente esse projeto de lei garante "novos" direitos aos povos indígenas, porém existem muitas divergências entre os interesses das comunidades indígenas e os interesses políticos do governo e de grupos econômicos.

Os atuais direitos indígenas no Brasil podem ser classificados em direitos territoriais, direitos culturais e direito à autodeterminação, diante da política integracionista e do princípio da soberania nacional. O que se pode considerar "novos" direitos são os referentes à diversidade etnocultural e à autodeterminação. Dessa forma, a criação do Estado associou-se à ideia de Nação, que reconhece a existência de uma cultura nacional e a igualdade de direitos, sem levar em consideração as diferenças entre etnias e culturas existentes no país.

\footnotetext{
${ }^{243}$ BRASIL, 1988, arts. $20,231, \S \S 1^{\circ}, 2^{\circ}$ e $6^{\circ}$.

${ }^{244}$ BRASIL. Câmara dos Deputados. Projeto de Lei n. 2.057/1991. Dispõe sobre o Estatuto das Sociedades Indígenas. Disponível em: http://www.camara.gov.br/proposicoesWeb/fichadetramitacao?idProposicao=17569>. Acesso em: 30 abr. 2017.
} 
A adoção do modelo jurídico ocidental para os povos indígenas baseado no conjunto de valores universais não garante uma convivência pacífica e harmônica entre eles, devido aos diversos interesses envolvidos para a integração política, econômica e social dessas minorias étnicas historicamente marginalizadas.

Nesse sentido, os Estados Nacionais precisam ampliar os espaços da pluralidade étnica e estabelecimento de um novo pacto constitucional, no qual os fatores étnicos sejam considerados relevantes, não para a fragmentação da sociedade nacional, mas para permissão de uma troca mútua de culturas e tradições, ocasionando um enriquecimento recíproco.

No entendimento de Will Kymlicka ${ }^{245}$, a cultura deve ser uma realidade dinâmica e plural, cujo objetivo é demonstrar que a dimensão cultural é constitutiva de indivíduos, que os direitos liberais têm de pressupor e de refletir essa culturalidade e, consequentemente, os Estados devem se organizar de modo a permitir a inclusão democrática de todos os grupos.

${ }^{245}$ KYMLICKA, Will. Ciudadanía multicultural. Barcelona: Paidós, 1996. p. 19. 


\section{O MULTICULTURALISMO ÉTNICO NO ESTADO BRASILEIRO E O DIREITO A IDENTIDADE CULTURAL DOS POVOS INDÍGENAS}

O multiculturalismo designa, originariamente, a coexistência de formas culturais ou de grupos que possuem traços culturais diferenciados no âmbito da sociedade moderna.

Existem diversos sentidos ao termo "multiculturalismo", nem todas no sentido de emancipação cultural, pois o próprio conceito de cultura é utilizado pela humanidade como fundamento de lutas políticas e consolidação de direitos sociais, de acordo com os preceitos estabelecidos pela autodeterminação dos povos.

Multiculturalismo pode também ser denominado de pluralismo cultural ou cosmopolitismo, que relaciona o reconhecimento ao respeito das diversidades culturais que historicamente estiverem à margem de um processo de desenvolvimento social, excluindo vozes ditas minoritárias em detrimento de um "padrão cultural" da sociedade moderna.

O conceito multicultural consagra uma ideologia com diversas compreensões derivadas de lutas travadas por minorias contra o Estado na busca de direitos historicamente negados.

Para Terry Eagleton ${ }^{246}$, a ideia de cultura denota um processo material que reúne tanto uma estrutura de base como uma superestrutura e a raiz da palavra "cultura" pode significar cultivar e proteger, as tradições de um povo.

Nesse sentido, o multiculturalismo consiste no reconhecimento pelo Estado da diversidade cultural e dos direitos pluriétnicos, os quais uma minoria possui. Amplia as discussões acerca dos valores e dos direitos individuais e coletivos.

Essas "aporias conceituais", conforme preceitua Semprini ${ }^{247}$ promove diferenças entre o multiculturalismo e o monoculturalismo, à medida que as controvérsias decorrentes desse choque repercutem diretamente nos entendimentos conceituais de cada um, conforme se observa a seguir:

a) Essencialismo e construtivismo: $O$ essencialismo é utilizado pelos que defendem o monoculturalismo, como fundamento objetivo de uma realidade social aplicado às minorias e suas identidades. Por outro lado, os pressupostos defendidos

\footnotetext{
${ }^{246}$ EAGLETON, Terry. A ideia de cultura. Tradução de Sandra Castello Branco. 2. ed. São Paulo: Unesp, 2011. p.10.

${ }^{247}$ SEMPRINI, Andréa. Multiculturalismo. Bauru: EDUSC, 1999. p. 90.
} 
pelos construtivistas são defendidos pelos multiculturalistas, os quais descrevem que as identidades das minorias resultam da própria evolução histórica de uma sociedade de maneira dinâmica e transformadora.

b) Universalismo e relativismo: O universalismo possui influência do lluminismo e materializa-se nas revoluções francesa e americana, os quais são traduzidos nas instituições democráticas, porém tenta eliminar a diferença e impor um ponto de vista particular, apresentado como universal. Por outro lado, os relativistas descrevem uma impossibilidade do estabelecimento de um ponto de vista universal para o atendimento dos preceitos de justiça em relação aos diversos grupos sociais e minorias étnicas.

c) Igualdade e diferença: A igualdade é um dos pressupostos do universalismo, que prevê direitos os quais sua efetividade se perde no formalismo jurídico. Por outro lado, os multiculturalistas defendem um espaço heterogêneo, que leve em consideração as diferenças existentes entre os indivíduos e suas diversidades étnicas.

d) Mérito objetivo e reconhecimento subjetivo: Os monoculturalistas defendem o mérito, baseado nos aspectos da competência e critérios objetivos de avaliação para a efetividade de direitos das minorias. Por outro lado, os multiculturalistas salientam a importância do reconhecimento como mecanismo de fortalecimento das minorias étnicas e construção de ações afirmativas para garantia de seus direitos fundamentais.

Dessa maneira, a autora Andréa Semprini descreve que essas quatro oposições são consideradas aporias que justificam o caráter conflituoso do multiculturalismo, cujo sua efetiva aplicação para a garantia de direitos fundamentais aos direitos indígenas baseados nos preceitos da Carta Magna, exige uma análise jurídica interdisciplinar.

Portanto, os direitos fundamentais possuem uma conditio sine qua non na formação democrática de opinião e de vontade, não podendo ser somente impostos, como limites ao exercício do poder político, nem meramente instrumentalizado politicamente ${ }^{248}$, devendo atender a efetiva participação popular na construção do

${ }_{248}$ OLIVEIRA, Marcelo Andrade Cattoni de. Processo constitucional. Belo Horizonte: Pergamum, 2013. p. 366. 
processo pluriétnico e multicultural no Estado brasileiro, conforme o art. 3, IV, Constituição Federal de 1988:

Art. 3ํㅡㄴ Constituem objetivos fundamentais da República Federativa do Brasil:

I - construir uma sociedade livre, justa e solidária;

II - garantir o desenvolvimento nacional;

III - erradicar a pobreza e a marginalização e reduzir as desigualdades sociais e regionais;

IV - promover o bem de todos, sem preconceitos de origem, raça, sexo, cor, idade e quaisquer outras formas de discriminação.

Nesse sentido, minorias e maiorias devem formar dinamicamente um processo político-democrático para o exercício de direitos, sob as condições de um pluralismo social e cultural democrático, capaz de exercer uma força legitimadora na garantia de direitos fundamentais.

\subsection{Nos termos da Constituição de 1988, a Emenda Constitucional 45, de 31 de dezembro de 2004 (Artigo 5, §3ํ CRFB)}

O sistema de proteção internacional de Direitos Humanos contribuiu para a consolidação de direitos fundamentais no âmbito brasileiro, sendo reforçado pela Constituição Federativa do Brasil de 1988.

Partindo-se dos preceitos básicos dos direitos humanos em que a indivisibilidade e a interdependência estão interligadas para a consolidação dos conceitos de igualdade e liberdade como fatores que se completam visando assegurar os direitos estabelecidos na Carta Magna.

Nesse sentido, a Constituição Brasileira de 1988 possui um fundamento jurídico relevante no processo de consolidação democrática e institucionalização dos direitos humanos, haja vista que a partir de 1985 após a ruptura com o regime autoritário militar de 1964, a posição do Estado Brasileiro no processo de democratização junto à ordem internacional possibilitou sua reinserção no plano internacional para proteção dos direitos humanos.

Dessa forma, ocorre a relação entre a Constituição da República Federativa do Brasil de 1988 e os Tratados Internacionais para a proteção dos direitos humanos, que ao concentrar seus esforços para a garantia de direitos do ser humano, por 
exemplo, a dignidade humana ${ }^{249}$, demonstra uma matéria de interesse constitucional, já que historicamente os direitos humanos possuem um conteúdo materialmente constitucional, tornando a respectiva pesquisa de enfoque interdisciplinar.

Busca-se não apenas ilustrar os dispositivos do Direito Constitucional que disciplinam os direitos humanos Internacionais no âmbito dos Estados, através da Independência Nacional; prevalência dos direitos humanos e autodeterminação dos povos, como mecanismo nacional de proteção dos direitos da pessoa humana, nos termos do art. 4, Il da Constituição Federal de 1988.

Nesse sentido, a cidadania será o requisito imprescindível para a construção dos preceitos constitucionais que irão nortear o Brasil nas relações internacionais, estabelecendo diálogos entre a Constituição Brasileira de 1988 e os Tratados Internacionais de Direitos Humanos.

A consolidação das liberdades fundamentais e seus reflexos nas instituições democráticas no país, promoverão uma mudança na política de proteção aos direitos humanos como reconhecimento de obrigações internacionais.

As consequências dessa nova perspectiva constitucional ocasionouaram mudanças no ordenamento jurídico interno do Estado Brasileiro, promovendo um novo constitucionalismo para a internacionalização da proteção aos direitos humanos e garantia dos direitos das minorias.

Em observância ao princípio da máxima eficácia e efetividade da Constituição, busca-se a maior aproximação entre o dever-ser normativo e o ser da realidade social $^{250}$ para assegurar as garantias fundamentais elencadas no art. $5^{\circ}$ da Carta Magna, em que todos são iguais perante a lei, sem distinção de qualquer natureza, garantindo-se aos brasileiros e aos estrangeiros residentes no País a inviolabilidade do direito à vida, à liberdade, à igualdade, à segurança e à propriedade, nos termos seguintes: I - homens e mulheres são iguais em direitos e obrigações, nos termos desta Constituição; II - ninguém será obrigado a fazer ou deixar de fazer alguma coisa senão em virtude de lei [...]; VI - é inviolável a liberdade de consciência e de crença,

\footnotetext{
249 BRASIL Constituição (1988). Constituição República Federativa do Brasil de 1988. Art. 1º A República Federativa do Brasil, formada pela união indissolúvel dos Estados e Municípios e do Distrito Federal, constituise em Estado Democrático de Direito e tem como fundamentos: I - a soberania; II - a cidadania; III - a dignidade da pessoa humana; IV - os valores sociais do trabalho e da livre iniciativa; V - o pluralismo político.

${ }^{250}$ BARROSO, Luís Roberto. Curso de direito constitucional contemporâneo. Rio de Janeiro: Forense. 2010. p. 305.
} 
sendo assegurado o livre exercício dos cultos religiosos e garantida, na forma da lei, a proteção aos locais de culto e as suas liturgias.

Também conhecido como princípio da eficiência, deve promover ao aplicador ou intérprete do direito o melhor sentido dos dispositivos constitucionais, de modo a promover maior eficácia às normas servindo de instrumento para assegurar a otimização da efetividade quanto norma de Direito Constitucional ${ }^{251}$.

Os direitos fundamentais inseridos em Tratados internacionais de direitos humanos, trata-se, de um aspecto relevante para compreensão da conexão estabelecida entre os direitos humanos de ordem internacional e os direitos fundamentais, de ordem interna.

Nesse contexto, o art. $5^{\circ} \S^{\circ}{ }^{\circ}$ da Constituição de 1988, refere-se apenas aos tratados internacionais, não realizando menção as convenções e outras espécies de regras constitucionais, conforme observa-se a seguir: Todos são iguais perante a lei, sem distinção de qualquer natureza, garantindo-se aos brasileiros e aos estrangeiros residentes no País a inviolabilidade do direito à vida, à liberdade, à igualdade, à segurança e à propriedade, nos termos seguintes, em que os direitos e garantias expressos nesta Constituição não excluem outros decorrentes do regime e dos princípios por ela adotados, ou dos tratados internacionais em que a República Federativa do Brasil seja parte.

Devido a imprecisão terminológica e da diversidade de expressões encontradas no Direito Constitucional não se verificando uma uniformização das diversas espécies de normas internacionais. Encontrando-se somente uma certa uniformidade na doutrina no que se refere a expressão genérica de "tratados internacionais", os quais englobam vários instrumentos internacionais como convenções e pactos.

Nesse sentido, os tratados são descritos na Convenção de Viena sobre o Direito dos Tratados como um "termo genérico", significando um acordo internacional independente de sua designação particular ${ }^{252}$. Sendo assim, considerado o acordo formal entre sujeitos de direito internacional público destinado a produzir efeitos jurídicos, de modo que o aspecto fundamental está relacionado à natureza do

\footnotetext{
${ }^{251}$ CANOTILHO, J.J. Gomes. Direito constitucional e teoria da constituição. 3. ed. Coimbra: Almedina, 1999. p. 1224.

252 TRINDADE, Antônio Augusto Cançado. Princípios do direito internacional contemporâneo. Brasília, DF: UnB. 1981. p.12.
} 
documento e não ao seu rótulo, em referência ao conceito, terminologia, espécies e formação dos tratados internacionais.

A interpretação ampla do conceito de tratados internacionais de direitos humanos é imprescindível para evitar a redução do entendimento da norma contida no art. $5^{\circ} \S 2^{\circ}$ da Constituição Federal de 1988, para que sua designação envolva relevantes instrumentos internacionais de direitos fundamentais, como Pactos Internacionais da ONU relacionados aos direitos civis e políticos, bem como, sobre os direitos econômicos, sociais e culturais de 1966, além da Convenção Americana de Direitos Humanos da Organização dos Estados Americanos de 1969.

No entanto, a Declaração Universal dos Direitos Humanos da Organização das Nações Unidas adotada na forma de uma Resolução não se enquadra na categoria de tratados internacionais, pelo menos não no sentido ilustrado pela Convenção de Viena ${ }^{253}$, não podendo ser enquadrado na categoria de tratados ou convenções de direitos humanos.

Nesse caso, o fato de uma Resolução da ONU não possuir efeito vinculante, parte dos direitos constantes na Declaração de 1948 se tornaram integrantes do direito internacional consuetudinário, portanto dos costumes internacionais e consequentemente, integram o sistema de fontes do direito internacional, passando com isso, a vincularem os Estados e os demais sujeitos de Direito Internacional.

$\mathrm{O}$ art. $5 \S 2^{\circ}$ da Constituição Federal expressamente se refere aos Tratados internacionais em que o Estado Brasileiro seja parte. Nesse sentido, precisa da intervenção do Congresso Nacional para sua ratificação ${ }^{254}$, para que os tratados internacionais acerca dos direitos humanos produzam efeito no ordenamento jurídico interno, passando a assegurarem direitos outorgados pela Carta Magna.

Esse procedimento de ratificação é complexo, pois envolve a participação do Poder Executivo através da assinatura do tratado pelo Presidente da República quanto chefe do Executivo para em seguida ser enviado ao Congresso Nacional.

253 SALIBA, Aziz Tuffi. Legislação de direito internacional. 10. ed. São Paulo: Rideel, 2015. p. 331. CONVENÇÃO DE VIENA SOBRE SUCESSÃO DE ESTADOS EM MATÉRIA DE TRATADOS. Art. $2^{\circ}$, 1, a. "Tratado" significa um acordo internacional concluído por escrito entre Estados e regido pelo Direito Internacional, quer conste de um instrumento único, quer de dois ou mais instrumentos conexos, qualquer que seja sua denominação específica.

254 CONVENÇÃ̃ de Viena sobre o direito dos tratados. Art. 2.1.b: "ratificação", "aceitação", "aprovação" e "adesão" significam, conforme o caso, o ato internacional assim denominado pelo qual um Estado estabelece no plano internacional o seu consentimento em obrigar-se por um tratado. Disponível em: <http://www.planalto.gov.br/ccivil_03/_ato2007-2010/2009/decreto/d7030.htm>. Acesso em: 11 dez. 2016. 
A aprovação pelo Congresso Nacional quanto Poder Legislativo através de decreto legislativo, haverá a constituição do ato de competência exclusiva do Congresso Nacional, não sujeitando-se à sanção presidencial, já que depois de aprovado pelo Legislativo, cabe ao Presidente da República concluir a formalização do tratado através de sua ratificação.

Após esse procedimento haverá a edição de um decreto de execução pelo Presidente da República, completando os aspectos formais é que haverá vinculação do tratado tanto na esfera interna quanto na esfera internacional ${ }^{255}$.

Embora esse procedimento seja o habitualmente utilizado, ocorreu uma significativa alteração no texto constitucional com a aprovação da Emenda Constitucional 45 de dezembro de 2004. Assim, o acréscimo do $3^{\circ}$ ao art.5ำ da Constituição Federal:

$\S 3^{\circ}$ Os tratados e convenções internacionais sobre direitos humanos que forem aprovados, em cada Casa do Congresso Nacional, em dois turnos, por três quintos dos votos dos respectivos membros, serão equivalentes às emendas constitucionais.

Possibilitou que, em harmonia com o art. $5^{\circ} \S^{\circ}{ }^{\circ}$ da CF houvesse também a formalização de direitos constitucionais para a garantia de preceitos fundamentais.

O posicionamento majoritário do Supremo Tribunal Federal (STF) 256 assegura que os tratados incorporados até dezembro de 2004, serão considerados normas supralegais prevalecendo toda e qualquer norma infraconstitucional interna, mas cedendo em face da Constituição Federal.

As normas supralegais não possuirão o status de Emenda Constitucional, por isso é importante realizar a diferença dos tratados ratificados antes da entrada em vigor da EC 45/2004 daqueles que ainda não tenham sido aprovados com o procedimento previsto no art. 5 $\S 3^{\circ}$ da Constituição Federal de 1988, que possuirão força normativa equivalentes às Emendas Constitucionais.

Nesse sentido, o art. 5ำ $3^{\circ}$ da Constituição Federal de 1988 não exige que sejam atendidos todos os preceitos formais, circunstanciais e temporais, referentes a um procedimento ordinário para aprovação de uma Emenda Constitucional, nos termos do art. 60 da Carta Magna:

255 MAZZUOLI, Valério de Oliveira. Curso de Direito Internacional Público. 6. ed. São Paulo: Revista dos Tribunais, 2012. p.341.

256 RE 466343/SP. Relator Ministro Cezar Peluso. Decisão Plenária de j. 03.12.2008. Disponível em: <http://redir.stf.jus.br/paginadorpub/paginador.jsp?docTP=AC\&docID=595444> Acesso em: 11 dez. 2016. 
Art. 60. A Constituição poderá ser emendada mediante proposta:

I - de um terço, no mínimo, dos membros da Câmara dos Deputados ou do Senado Federal;

II - do Presidente da República;

III - de mais da metade das Assembleias Legislativas das unidades da Federação, manifestando-se, cada uma delas, pela maioria relativa de seus membros.

$\S 1^{\circ}$ A Constituição não poderá ser emendada na vigência de intervenção federal, de estado de defesa ou de estado de sítio.

$\S 2^{\circ}$ A proposta será discutida e votada em cada Casa do Congresso Nacional, em dois turnos, considerando-se aprovada se obtiver, em ambos, três quintos dos votos dos respectivos membros.

$\S$ 3 A emenda à Constituição será promulgada pelas Mesas da Câmara dos Deputados e do Senado Federal, com o respectivo número de ordem.

Destaca-se que, a aprovação do Tratado de direitos humanos nos termos do art. $5^{\circ} \S^{\circ} 3^{\circ}$ da Constituição Federal não necessita obrigatoriamente ser levada a efeito por meio de uma Emenda Constitucional, bastando somente a aprovação, nos termos do art. $5^{\circ} \S 2^{\circ}$ da Carta Magna, para que o mesmo seja considerado equivalente a uma Emenda constitucional.

Não existe um impedimento legislativo em que uma outra espécie legislativa seja utilizada para a aprovação de um tratado, pois havendo o atendimento dos requisitos estabelecidos no art. $5^{\circ} \S^{\circ} 3^{\circ}$ da Consttuição Federal e estando devidamente aprovado, este possuirá a mesma hierarquia das Emendas Constitucionais agregando a Constituição ao efetivo direito, para a garantia dos ditames internacionais vigentes.

Assim, os tratados internacionais de direitos humanos dependem de ratificação pelo Brasil e são incorporados ao ordenamento jurídico interno de maneira complexa com a atribuição do Presidente da República e do Congresso Nacional e aqueles aprovados nos termos do art. 5ำ $3^{\circ}$ da Constituição Federal de 1988, também não dispensam a ratificação do respectivo Tratado.

Logo, um Tratado Internacional de Direitos Humanos não poderá ser denunciado pelo Presidente da República sem a devida anuência do Congresso Nacional, porque deve existir um rigoroso controle de constitucionalidade para assegurar a proteção dos direitos humanos. 
No entanto, a Suprema Corte Brasileira possui como entendimento majoritário que, uma vez um tratado aprovado não poderá ser denunciado, nem mesmo com a prévia aprovação pelo Congresso Nacional257, como garantia da segurança jurídica no ordenamento interno e consolidação dos preceitos fundamentais que norteiam os direitos humanos internacionais ${ }^{258}$.

\subsection{A consolidação de Direitos Fundamentais na Lei n. 6.001 que institui o Estatuto do Índio}

O Regime Militar no Brasil trouxe a questão indígena brasileira um tratamento político-institucional bastante negativo para essas minorias étnicas.

O Serviço de Proteção ao Índio (SPI) que possuía como objetivo a pacificação dos conflitos indígenas nas frentes de ocupação do território nacional, sofreu inúmeras denúncias contra seus agentes ensejando a Comissão Parlamentar de Inquérito (CPI) indígenas, devido a atuação violenta de seus agentes para atender uma política nacional da época, visando a retirada dos indígenas de seus territórios através de uma cultura assimilacionista e a implementação do plano de desenvolvimento infraestrutural, materializado por exemplo, nas grandes obras de integração nacional como a rodovia transamazônica.

Com a mudança do SPI para Fundação Nacional do Índio (FUNAI), houve a criação de um órgão de conformação jurídica que possuía como finalidade a transformação cultural indígena, para que suas características étnicas e culturais específicas de um povo, nos termos do art. 1ํ da Convenção de 1989 sobre Povos Indígenas e Tribais em Países Independentes n. 169259, adotada pela Organização

${ }^{257}$ RAMOS, André de Carvalho. O Supremo Tribunal Federal e o direito internacional dos direitos humanos. In: SARMENTO, Daniel; Ingo Wolfgang (Coord.). Direitos fundamentais no Supremo Tribunal Federal: balanço e crítica. Rio de Janeiro: Lumen Juris, 2011. p.15.

258 ADIn 1625 de 19 de junho de 1997. Julgamento em que se questiona a constitucionalidade da denúncia unilateral da Convenção 158 da Organização Internacional do Trabalho, a qual possui como vinculação o Decreto Presidencial 2.100 de 20.12.1996. Nessa ação alega-se que houve violação do art. 49, inciso 1 da Constituição Federal, a qual atribui competência exclusiva do Congresso Nacional para resolver definitivamente sobre tratados, acordos ou atos internacionais que acarretem encargos ou compromissos gravosos ao patrimônio nacional. Argumenta-se também que, a Convenção 158 da OIT foi aprovada e promulgada pelo Congresso Nacional, não cabendo, portanto, ao Presidente da República editar decreto revogando a promulgação que assegura direitos fundamentais plenamente constituídos. Disponível em: <http://stf.jusbrasil.com.br/jurisprudencia/14769068/acao-direta-de-inconstitucionalidade-adi-1625-uf-stf>. Acesso em: 11 dez. 2016.

259 CONVENÇÃO 169. Organização Internacional do Trabalho - OIT. Disponível em: <http://www .planalto.gov.br/ccivil_03/_ato2004-2006/2004/decreto/d5051.htm>. Acesso em: 14 dez. 2016. 
Internacional do Trabalho (OIT), fossem convertidas para uma sociedade considerada no momento histórico "civilizada", porém, excludente e marginalizadora dos anseios sociais étnicos, conforme o art. $1^{\circ}$ inciso $V$ da Lei $5.371 / 67^{260}$ em que fica o Governo Federal autorizado a instituir uma fundação, com patrimônio próprio e personalidade jurídica de direito privado, nos termos da lei civil, denominada "Fundação Nacional do Índio", com as seguintes finalidades: I - estabelecer as diretrizes e garantir o cumprimento da política indigenista, baseada nos princípios a seguir enumerados; V - promover a educação de base apropriada do índio visando à sua progressiva integração na sociedade nacional.

Ficando evidente que, a continuidade histórica de um povo desde o período colonial, que se desenvolveram em territórios distintos de outros setores da sociedade, mas que preservam e desenvolvem a cultura de seus ancestrais como sua identidade étnica, deveria passar por uma educação com parâmetros de inclusão étnico e cultural, para serem integrados efetivamente na sociedade.

Essa ação adotada pelo Regime Militar nas políticas e legislações indigenistas, quando foi editada a Lei n. 6.001/73 - Estatuto do Índio, viola os preceitos internacionalmente assegurados pela ONU na defesa das minorias, conforme observa - Relator Especial da Subcomissão de problema da discriminação contra as populações indígenas, José R. Martínez Côbo.

Para o Relator Especial Martínez, essa continuidade histórica de um povo consiste em diversos aspectos como:

a) Ocupação de terras considerada de seus ancestrais;

b) Ancestralidade comum com os ocupantes originais dessas terras;

c) Através da cultura de um modo geral ou por manifestações específicas como religião desenvolvida sob um sistema tribal ou o pertencimento a uma comunidade indígena;

d) Por intermédio de uma língua seja ela materna ou habitual de comunicações entre povos;

e) Residência em certas partes do país ou regiões do mundo.

Dessa forma, individualmente, um indígena é aquele que pertence a essas populações indígenas por autoidentificação como indígena através da consciência de grupo, sendo reconhecido e aceito por essas populações como um de seus membros

${ }^{260}$ Lei 5.371/67 - Institui a Fundação Nacional do Índio - FUNAI. Disponível em: <http://www.planalto.gov .br/ccivil_03/leis/1950-1969/L5371.htm>. Acesso em: 14 dez. 2016. 
pela aceitação do grupo. Isso preserva a essas comunidades o direito soberano e o poder de decidir quem pertence a elas, sem uma interferência externa.

Apesar das considerações adotadas internacionalmente, o Estatuto do Índio editado em 19 de dezembro de 1973, demonstrou que no Projeto de Integração Nacional, os indígenas eram considerados um entrave ao processo de desenvolvimento, violando os preceitos da Declaração Universal de Direitos Humanos de 1948 e os Pactos Internacionais para a garantia dos direitos Civis e Políticos (PIDCP) e de direitos econômicos, sociais e culturais (PIDESC) ambos de 1966.

Assim, a intenção para a incorporação dos povos indígenas à comunidade nacional consistia em aniquilar a identidade cultural desses grupos étnicos, uma vez que a predominância do momento histórico era a "civilização" e não o reconhecimento e manutenção das diferenças existentes.

Com o advento da Constituição Federal de 1988 elaborada no momento histórico brasileiro de redemocratização, o texto constitucional representou um relevante avanço para a garantia de direitos fundamentais às minorias étnicas pautados na dignidade da pessoa humana.

\subsection{Reconhecimento e a diversidade étnica no Estado Democrático de Direito}

A Constituição de 1988 admitiu, implicitamente, a existência de um pluralismo étnico ao tratar sobre a questão indígena em seu Capítulo VIII ${ }^{261}$. Segundo Jacques d'Adesky, a Carta Magna Brasileira reconheceu em seu art. 215, que a realidade de uma sociedade pluricultural cujas diversas manifestações, populares, indígenas e afro-brasileiras devem ser protegidas, usando a expressão segmentos étnicos nacionais 262 .

Indaga-se que a proteção aos povos indígenas seria uma forma de reconhecimento ou mais um meio de propiciar a sua assimilação estatal, que não prioriza a autodeterminação desses povos, porém para Miguel León-Portilla, apenas o reconhecimento jurídico dos direitos indígenas tornam-se insuficientes para a garantia de seus direitos fundamentais baseados nas disposições constitucionais

\footnotetext{
${ }^{261}$ BRASIL, 1988.

${ }^{262}$ D'ADESKY, 2001. p. 201.
} 
vigentes $^{263}$. O texto constitucional, na compreensão de d'Adesky, não definiu etnia e pluralismo cultural, entretanto, implicitamente pode-se admitir três concepções:

A primeira, ao se referir à pessoa humana, liga-se diretamente ao fundamento universal que define o cidadão sem qualquer distinção de raça, religião, sexo ou cultura.

A segunda reconhece implicitamente a diversidade étnica, ao utilizar as expressões "populações indígenas" e "segmentos étnicos nacionais".

A terceira concepção possui o entendimento de pluralismo cultural como patrimônio comum da nação, razão pela qual deve ser protegido ${ }^{264}$.

O Estatuto Jurídico dos Povos Indígenas ${ }^{265}$ está sendo discutido internacionalmente há anos, sobretudo em países como o Brasil, que no seu último relatório oficial às Nações Unidas e à Comissão de direitos humanos reforçou suas obrigações para com os povos indígenas. A proteção dos povos indígenas, também denominados povos autóctones ou aborígenes, tornou-se uma das ênfases nas atividades daquelas organizações internacionais empenhadas na garantia dos direitos humanos.

Isso se atribui às circunstâncias de que a codificação dos direitos humanos, nos dias atuais, apresenta uma intensa complexidade e que a proteção de grupos vulneráveis se encontra no centro desse corpo jurídico. Sabe-se que os ditames jurídicos gerados na história do recente constitucionalismo, mantenedor de status, possui intensa interferência na visão dos direitos humanos, nas limitações, potencialidades e preconceitos que suas entrelinhas abrigam.

Sendo que, os excluídos e marginalizados do processo de desenvolvimento social como as minorias étnicas, não dispondo recursos para sua efetiva emancipação assumem para si uma visão hegemônica dos direitos humanos, já que em grande parte, sua condição histórica e social não são levadas em consideração para a geração de políticas públicas eficazes que Ihe ofereçam uma produção social e cultural de riquezas.

Nesse sentido, a universalização dos direitos humanos não significa necessariamente sua homogeneização e sua indivisibilidade não significa que não haja diferenças entre os diversos setores que se organizam a sociedade para a

\footnotetext{
${ }^{263}$ LÉON-PORTILLA, 1995. p. 39.

${ }^{264}$ D'ADESKY, 2001. p. 187-188.

${ }^{265}$ BRASIL, 1991.
} 
implementação do direito, o que de algum modo, em contexto menos favoráveis para a consolidação dos direitos humanos, podem legitimar a exclusão social.

O que por outro lado, as graduais conquistas dos movimentos sociais étnicos podem assegurar em si mesmo um status político, social e jurídico mais protecionistas para as violações de direitos humanos, já que atenderia o reconhecimento dos direitos indígenas como uma luta afirmativa para a garantia de direitos fundamentais ${ }^{266}$.

À luz das experiências históricas, é fato que a sobrevivência dos povos indígenas e a proteção de suas culturas somente serão possíveis em escala mundial com os Estados e organismos internacionais desempenhando um esforço coletivo para a manutenção e consolidação dos direitos indígenas.

Muitas propostas para a identificação dos povos indígenas serão aplicadas na prática pelos Estados. Nesse contexto remete-se à definição apresentada pelo Relator Especial das Nações Unidas, Martínez Cobo267:

Indigenous communities, peoples and nations are those which, having a historical continuity with pre-invasion and pre-colonial societies that developed on their territories, consider themselves distinct from other sectors of the societies now prevailing in those territories, or parts of them. They form at present non-dominant sectors of society and are determined to preserve, develop and transmit to future generations their ancestral territories, and their ethnic identity, as the basis of their continued existence as peoples, in accordance with their own cultural patterns, social institutions and legal systems ${ }^{268}$.

266 BITTAR, Eduardo C.B. Direitos Humanos no Século XXI: cenários de tensão. Rio de Janeiro: Forense Universitária; São Paulo: ANDHEP; Brasília: Secretaria Especial dos Direitos Humanos, 2009. p.280.

267 MARTINEZ COBO, Jose R. Study of the problem of discrimination against indigenous populations. In: PROPOSALS and Recommendations, prepared by Mr. José R. Martínez Cobo, New York, United Nations, 1983. United Nations. Permanent Forum on Indigenous Issues. V.5. Conclusiones. Disponível em: $<$ http://undesadspd.org.dnnmax.com/IndigenousPeoples/LibraryDocuments/Mart\%C3\%ADnezCoboStudy.as px>. Acesso em: 13 dez. 2016.

268 Tradução: As nações, povos e comunidades indígenas são aquelas que, tendo uma continuidade histórica com as sociedades pré-invasivas e pré-coloniais que se desenvolveram em seus territórios, se consideram distintas dos demais setores das sociedades que hoje prevalecem nesses territórios ou em partes deles. Elas formam atualmente setores não dominantes da sociedade e estão determinadas a preservar, desenvolver e transmitir às gerações futuras seus territórios ancestrais e sua identidade étnica, como base de sua continuidade como povos, de acordo com seus próprios padrões culturais, sociais Instituições e sistemas jurídicos. 
Figura 4 - Estrutura orgânico-funcional da Organização das Nações Unidas - ONU (sentido lintegrado).

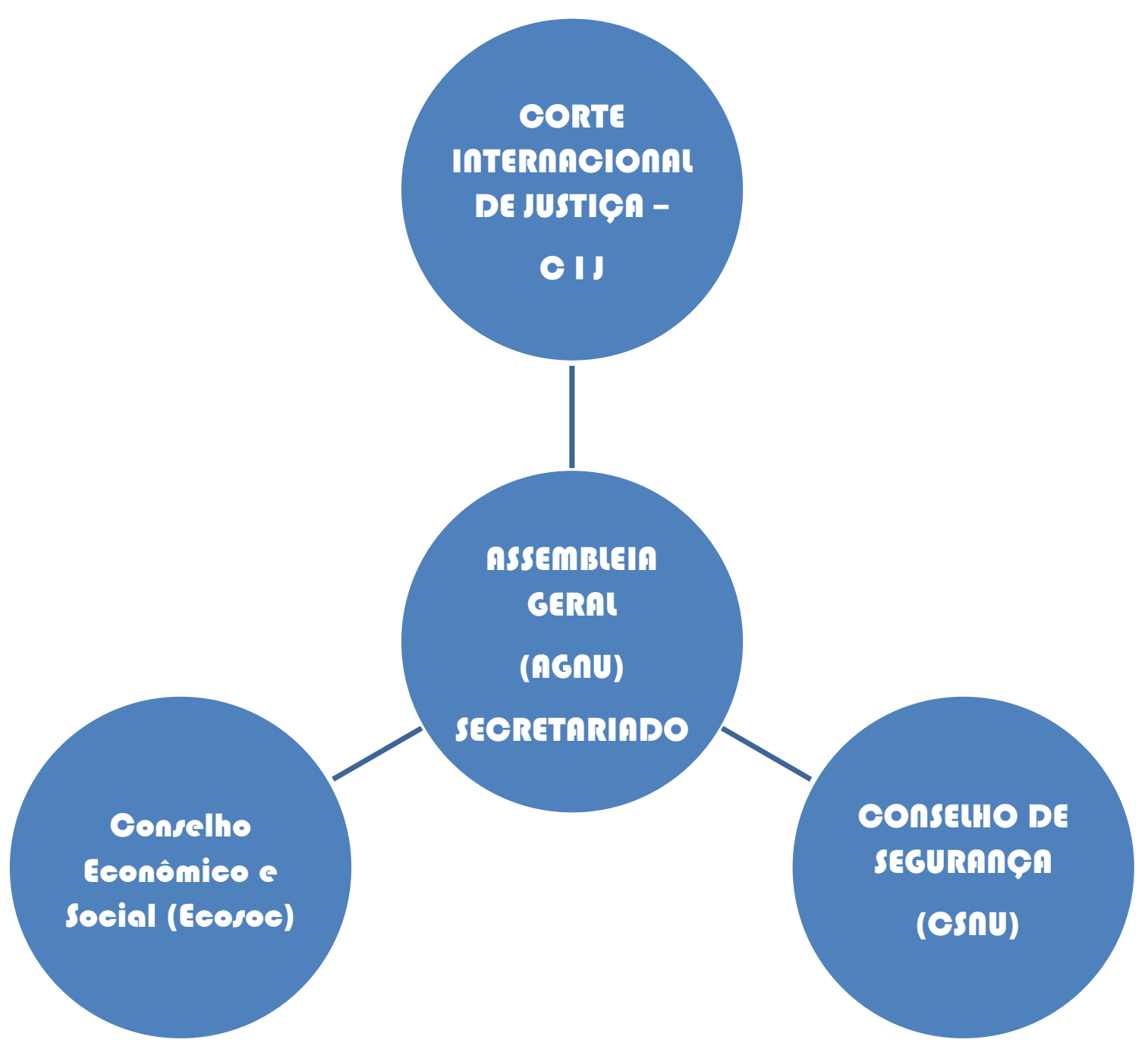

Fonte: Elaborada pela autora, 2017. 
Figura 5 - Estrutura das Nações Unidas em relação aos povos indígenas.

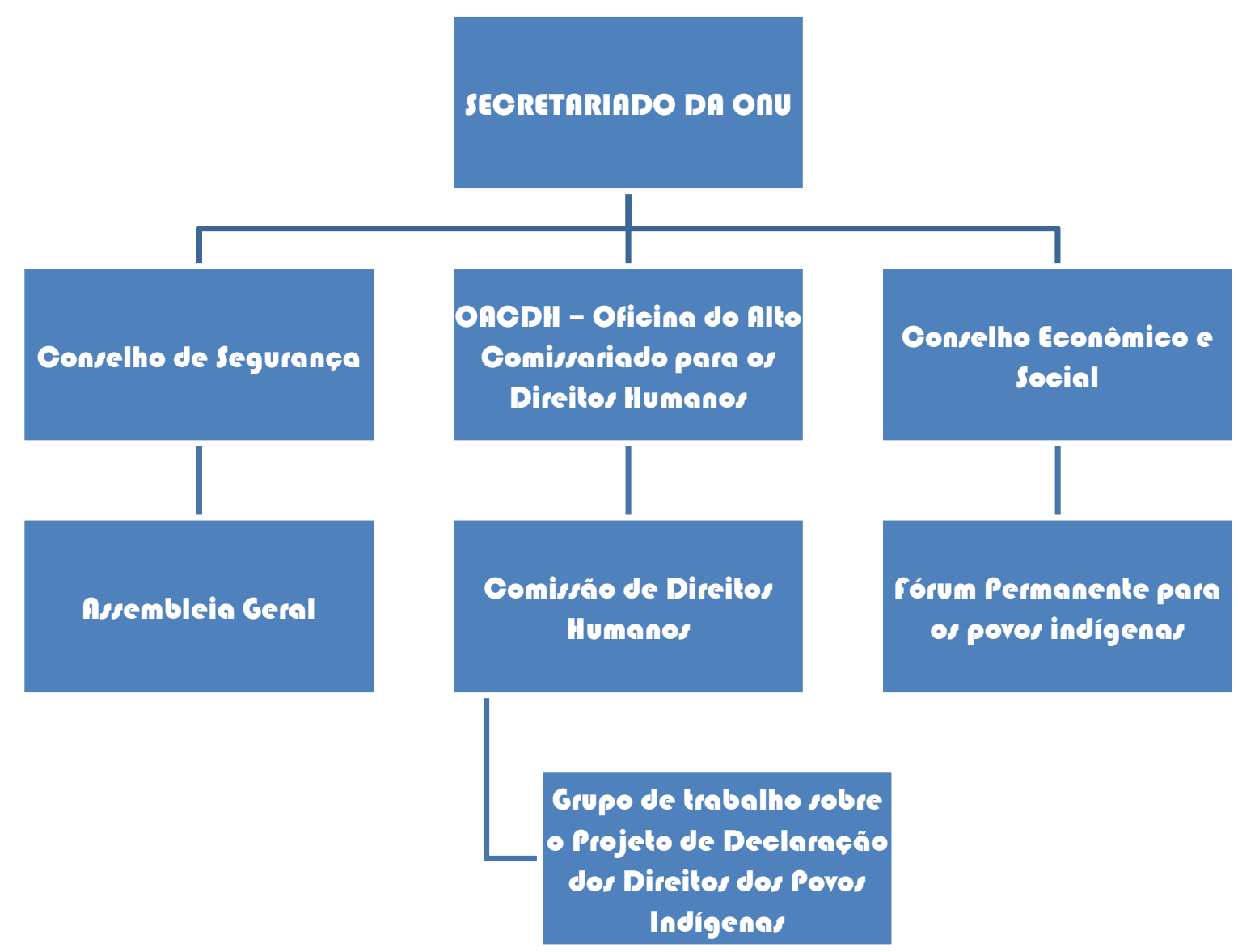

Fonte: Elaborada pela autora, 2017.

Nesse sentido, as relações do Estado com os povos indígenas complicam-se porque, nos tempos da colonização, vigorava a opinião de que as terras conquistadas dos povos indígenas eram terras de ninguém (terra nullius), que poderiam ser ocupadas pelos Estados "civilizados". 
Assim, os direitos dos povos indígenas ocupam uma posição especial porque do ponto de vista técnico não podem ser configurados como parte da proteção dos direitos individuais, em razão de os Estados fixarem uma configuração específica de direitos indígenas, o que resulta na possibilidade de qualificações e direitos derivados serem diferentes de um Estado para o outro, diferentemente da proteção dos direitos humanos. Dessa forma, a questão indígena ganhou amplitude com a Constituição Brasileira de 1988, conforme se destaca a seguir:

O art. 20, inciso XII da Constituição Federal de 1988, inclui entre os bens da União as terras tradicionalmente ocupadas pelos índios.

$\mathrm{O}$ art. 22, inciso XIV do dispositivo legal acima mencionado, determina a competência privativa da União para legislar sobre questões indígenas, rompendo com a legislação anterior, que determinava a competência da União para legislar sobre a incorporação do índio à sociedade nacional.

Dessa maneira, a atual Constituição conferiu o direito ao reconhecimento e o respeito à diversidade cultural indígena.

O art. 49, inciso XVI da Constituição Federal de 1988, estabelece competência exclusiva do Congresso Nacional, para autorizar a exploração e o aproveitamento de recursos hídricos e a pesquisa de lavra sobre as riquezas minerais nas terras indígenas.

O art. 109, inciso XI da Carta Magna, fixa a competência da Justiça Federal para processar e julgar disputas sobre direitos indígenas.

$\mathrm{O}$ art. 129, inciso $\mathrm{V}$ do referido dispositivo, inclui entre as funções institucionais do Ministério Público, a defesa jurídica dos direitos e interesses das populações indígenas.

O art. 215 da Constituição Federal de 1988, assegura às comunidades indígenas o ensino fundamental bilíngue, utilizando sua língua de matriz étnica e do seu próprio processo de aprendizagem, visando que o Estado garanta o efetivo exercício dos direitos culturais e acesso às fontes de cultura nacional indígena, apoiando e incentivando a valorização e a difusão das manifestações culturais pluriétnicas.

O Estado também deverá proteger as manifestações das culturas populares, indígenas e afro-brasileiras, além de outros grupos participantes do processo civilizatório nacional, dispondo a fixação de datas comemorativas de alta significação para os diferentes segmentos étnicos nacionais. Estabelecendo o Plano Nacional de 
Cultura, de duração plurianual, visando o desenvolvimento cultural do País e a integração das ações do Poder Público, promovendo a defesa e valorização do patrimônio cultural brasileiro e da difusão de bens culturais; elementos fundamentais para a formação de educadores que incentivem a gestão étnica do processo educacional e da cultura em suas múltiplas dimensões, democratizando o acesso à justiça indígena através dos bens culturais e da valorização de minorias étnicas, como agentes de desenvolvimento social.

Dessa forma, os arts. 231 e 232 da Carta Magna, elencam o reconhecimento aos índios de sua organização social, costumes, línguas, crenças e tradições, além do direito originário sobre as terras que ocupam:

Art. 231. São reconhecidos aos índios sua organização social, costumes, línguas, crenças e tradições, e os direitos originários sobre as terras que tradicionalmente ocupam, competindo à União demarcálas, proteger e fazer respeitar todos os seus bens.

$\S 1^{\circ}$ São terras tradicionalmente ocupadas pelos índios as por eles habitadas em caráter permanente, as utilizadas para suas atividades produtivas, as imprescindíveis à preservação dos recursos ambientais necessários a seu bem-estar e as necessárias a sua reprodução física e cultural, segundo seus usos, costumes e tradições.

$\S 2^{\circ}$ As terras tradicionalmente ocupadas pelos índios destinam-se a sua posse permanente, cabendo-Ihes o usufruto exclusivo das riquezas do solo, dos rios e dos lagos nelas existentes.

$\S 3^{\circ} \mathrm{O}$ aproveitamento dos recursos hídricos, incluídos os potenciais energéticos, a pesquisa e a lavra das riquezas minerais em terras indígenas só podem ser efetivados com autorização do Congresso Nacional, ouvidas as comunidades afetadas, ficando-lhes assegurada participação nos resultados da lavra, na forma da lei.

$\S 4^{\circ}$ As terras de que trata este artigo são inalienáveis e indisponíveis, e os direitos sobre elas, imprescritiveis.

§ 5 É vedada a remoção dos grupos indígenas de suas terras, salvo, "ad referendum" do Congresso Nacional, em caso de catástrofe ou epidemia que ponha em risco sua população, ou no interesse da soberania do País, após deliberação do Congresso Nacional, garantido, em qualquer hipótese, o retorno imediato logo que cesse 0 risco.

$\S 6^{\circ}$ São nulos e extintos, não produzindo efeitos jurídicos, os atos que tenham por objeto a ocupação, o domínio e a posse das terras a que se refere este artigo, ou a exploração das riquezas naturais do solo, dos rios e dos lagos nelas existentes, ressalvado relevante interesse público da União, segundo o que dispuser lei complementar, não gerando a nulidade e a extinção direito a indenização ou a ações contra a União, salvo, na forma da lei, quanto às benfeitorias derivadas da ocupação de boa fé. 
$\S 7^{\circ}$ Não se aplica às terras indígenas o disposto no art. 174, § $3^{\circ}$ e $\S$ 4 .

Art. 232. Os índios, suas comunidades e organizações são partes legítimas para ingressar em juízo em defesa de seus direitos e interesses, intervindo o Ministério Público em todos os atos do processo.

Nesse sentido, a Constituição Federal de 1988 possui relevantes valores acerca dos direitos indígenas, porém ainda é preciso integrar de maneira eficiente os pressupostos de desenvolvimento social, político, econômico e cultural do Direito Internacional para a concretização dos preceitos fundamentais das minorias étnicas marginalizadas ao longo de seu processo histórico de desenvolvimento. 


\section{A CONSOLIDAÇÃO DA IDENTIDADE INDÍGENA E A FRICÇÃO INTERÉTNICA}

A identidade indígena para a consolidação dos ditames pluriétnicos e multiculturais das minorias étnicas baseia-se nos pressupostos defendidos por Charles Taylor ${ }^{269}$ que correspondem à interpretação que uma pessoa faz de si mesma e das características fundamentais que a definem como ser humano.

Jürgen Habermas ${ }^{270}$ também defende a ideia de "identidade bem-sucedida", em que os sujeitos possuem a capacidade peculiar de falar e agir para permanecerem idênticos a si mesmos, mesmo sob mudanças profundas na estrutura de sua personalidade.

Nesse sentido, a identidade é construída com base na compreensão de si mesmo e dos que estão à volta, por meio da aquisição de significados compartilhados, porque é na interação do outro que o sujeito se constitui.

A inter-relação entre identidade e reconhecimento é imprescindível para que cada indivíduo seja original e diferente, determinando seu modo de viver e interagir socialmente, conforme os ensinamentos de Charles Taylor ${ }^{271}$.

Dessa maneira, a originalidade construída coloca o sujeito em uma relação mais ampla para a construção do direito à diferença, considerado relevante fundamento para a consolidação dos direitos indígenas.

O reconhecimento da identidade indígena é importante porque sua ausência consiste em opressão às identidades étnicas historicamente não valorizadas, descriminadas e oprimidas. Sua valorização de maneira lenta e gradual constituiria um mecanismo eficiente de uma mudança gradativa da imagem excludente construída em relação aos povos indígenas, mantido de algum modo no seio da atual sociedade, seja por meio da ineficácia das políticas públicas que contribuem para esse processo de marginalização social, seja pela inobservância dos preceitos culturais desrespeitados em relação às minorias étnicas em questão.

\footnotetext{
${ }^{269}$ TAYLOR, Charles. El multiculturalismo y “la política del reconocimiento”. Tradução de de Mónica Utrilla de Neira. México: Fondo de Cultura Económica, 2001. p. 155.

${ }^{270}$ HABERMAS, Jürgen. Pensamento pós-metafísico: estudos filosóficos. Rio de Janeiro: Tempo Brasileiro, 1990. p.78-81.

271 TAYLOR, Charles. As fontes do self: a construção da identidade moderna. São Paulo: Edições Loyola, 1997. p. 51-71.
} 
Para Charles Taylor, as identidades modernas dos "povos originários" são o resultado da necessidade que esses povos têm de incorporar em seu modo de vida meios de sobrevivência do novo mundo em que foram obrigados a se inserir, por isso sofrem o processo de marginalização social, em nome de uma [suposta] cidadania universal, que não deixa de ser novas formas de colonialismo etnocêntrico, conforme se observa a seguir:

[...] após gerações, a sociedade branca forjou uma imagem depreciativa à qual certamente [os discriminados] não tiveram força para resistir. Desse ponto de vista, esta autodepreciação tornou-se uma das armas mais eficazes de sua própria opressão. Seu primeiro objetivo deverá ser desembaraçar-se dessa identidade imposta e destrutiva. Recentemente, uma análise semelhante foi feita pelos povos indígenas e colonizados em geral ${ }^{272}$.

Jessé Souza ${ }^{273}$ ilustra que o reconhecimento da diferença constitui a dignidade na sociedade moderna, já que os sujeitos da modernidade buscam a efetividade de direitos na dignidade e nas suas especificidades étnicas, como ocorre com os povos indígenas.

Sabe-se, portanto, que o contato interétnico é o fenômeno mais comum da modernidade, o qual se estabelece mediante relações entre indivíduos e grupos de diversas procedências nacionais, raciais ou culturais. Essa identificação étnica com o outro é como se realiza o estabelecimento de uma interconexão entre grupo étnico e cultura.

Esses elementos são relevantes uma vez que grande parte deles é desconsiderada na construção dos direitos indígenas, pois pressupõe-se uma única identidade étnica nesse amplo universo racial, nacional e religioso.

Ricardo Cardoso de Oliveira ${ }^{274}$ afirma que essa peculiaridade cultural é complexa, refletindo diretamente na própria garantia dos direitos étnicos, que precisa de outras variantes para aferir o reconhecimento de um grupo étnico, conforme se observa:

É assim que em ambos os lados da fronteira pode-se constatar a existência de contingentes populacionais não necessariamente

\footnotetext{
272 TAYLOR, 2013. p. 42.

${ }^{273}$ SOUZA, Jessé. A construção social da subcidadania: Para uma sociologia política da modernidade periférica. Rio de Janeiro: IUPERJ, 2003. p.67.

${ }^{274}$ OLIVEIRA, Roberto Cardoso de. Identidade, etnia e estrutura social. São Paulo: Pioneira, 1976. p. 3.
} 
homogêneos, mas diferenciados pela presença de indivíduos ou grupos pertencentes a diferentes etnias, sejam elas autóctones ou indígenas, sejam provenientes de outros países pelo processo de imigração. Ora, isso confere à população inserida no contexto de fronteira um grau de diversificação étnica que, somado à nacionalidade natural ou conquistada do conjunto populacional de um e de outro lado da fronteira, cria uma situação sociocultural extremamente complexa ${ }^{275}$.

Nesse sentido, os movimentos sociais de caráter reformistas guardam em si suas ideologias étnicas, as quais são etnocêntricas como marco de referência para garantia de direitos pluriétnicos e multiculturais, estabelecendo relações sociais relevantes que assegurem os direitos fundamentais das minorias étnicas.

Quadro 2 - Comparativo da matriz dos sistemas interétnicos.

\begin{tabular}{|c|c|c|}
\hline & INTERTRIBAIS & INTERÉTNICOS \\
\hline SIMETRIA & Relações igualitárias (1) & Relações igualitárias (4) \\
\hline ASSIMETRIA & Relações hierárquicas (2) & $\begin{array}{l}\text { Relações de sujeição- } \\
\text { dominação (3) }\end{array}$ \\
\hline
\end{tabular}

Fonte: OLIVEIRA, 1976.

O sistema de identificação número 1 aglutina grupos indígenas no conjunto intercultural, em que as unidades étnicas em contato mantêm relações igualitárias sem supremacia sistemática de uma com a outra.

Esse fenômeno pode ser visualizado na região do alto rio Xingu, no Estado do Mato Grosso, em que tribos falando diferentes línguas, como Tupi, Aruaque, Karib e Trumai, mantêm um modo de viver tão integrado que se tornou possível o desenvolvimento de uma área cultural indígena denominada "área do Uluri276". Nesse espaço não há "superioridade" de um grupo étnico sobre outro, mas relações entre grupos tribais que possuem contato permanente e contínuo definidos por simetrias e igual respeito cultural.

275 OLIVEIRA, Roberto Cardoso de. Os (des)caminhos da identidade. Revista Brasileira de Ciências Sociais, v.15, n.42, 2000. p. 16-21. Disponível em: <http://www.scielo.br/pdf/rbcsoc/v15n42/1733.pdf>. Acesso em: 13 maio 2017.

${ }^{276}$ SILVA. Orlando Sampaio; GALVÃO, Eduardo (Coord.). Índios e caboclos. São Paulo: Annablume, 2007. p. 67. 
O sistema de identificação número 2 contém grupos indígenas em relações assimétricas, uma vez que estão hierarquicamente justapostos, envolvendo grupos étnicos marcados por status tribal que sofreram um recondicionamento etnossocial, por força do contato sistemático com outros grupos étnicos, caracterizando, portanto, um sistema intertribal com caráter assimétrico.

Esse sistema ocorre com os grupos étnicos Guaná e Guaykuru ${ }^{277}$, de procedência hispânica, quando eles migravam para 0 território brasileiro e estabeleciam suas relações intertribais.

O sistema número 3 baseia-se numa ordem oposta de relações, considerado rigorosamente assimétrico e não podendo ser explicado por meio de um modelo hierárquico, envolvendo grupos tribais e segmentos da sociedade com grande poder de determinação na dinâmica do sistema interétnico, por sua força econômica para o estabelecimento de uma relação de dominação no modelo de "fricção interétnica".

Roberto Cardoso de Oliveira ${ }^{278}$ descreve o caráter conflituoso desencadeado nas relações interétnicas, pautadas numa estrutura social de sujeição e dominação, que também pode ser analisada na perspectiva das relações sociais que envolvem os aspectos culturais inseridos no plano social global de desenvolvimento, para a promoção de políticas públicas inclusivas e a consolidação de matrizes sociais que visem ao fortalecimento de ações afirmativas para as populações indígenas.

Nesse sentido, as unidades étnicas em contato, principalmente entre índios e brancos, possuem uma relação de contradição, uma vez que a existência de uma nega a existência da outra, por serem inconciliáveis suas posições no no sistema interétnico.

Assim, as ideologias étnicas produzidas por movimentos sociais pretendem estabelecer uma "gramática social, que oriente seus agentes de desenvolvimento social na luta por reconhecimento e por medidas concretas de inserção social.

Dessa forma, se as políticas afirmativas de inserção social fossem mais eficientes no processo de desenvolvimento social, a "fricção interétnica" poderia ser considerada um eixo relevante de desenvolvimento social, já que promove um processo de articulação social a outros processos que se entrelaçam, de algum modo,

\footnotetext{
277 FABRE, Alain. Diccionario etnolingüístico y guía bibliográfica de los pueblos indígenas sudamericanos. Arawak. 2005. Disponível em: 〈http://www.ling.fi/Entradas\%20diccionario/Dic=Arawak.pdf〉. Acesso em: 13 maio 2017.

278 OLIVEIRA, 1976.
} 
na sociedade para a construção de um processo social mais inclusivo destinado às minorias étnicas e demais grupos em situação de vulnerabilidade.

Por outro lado, o sistema número 4, diferentemente dos demais, constitui uma possibilidade teórica, uma vez que empiricamente não se pode afirmar que ele se realize efetivamente como os demais, pois trata-se de um sistema interétnico conjugado por "índios" e "brancos", em que suas relações estariam permeadas pela simetria. No entanto, as relações interétnicas realizadas de maneira igualitária e despojada de qualquer "fricção interétnica" na prática não se realiza, haja vista que ocorreria uma ideologia cultural em relação ao caso abordado.

A luta pelo reconhecimento dos povos indígenas, portanto, também constitui uma forma de conflito sociopolítico, além dos aspectos interétnicos levados em consideração para a construção dos direitos multiculturais. Para Nancy Fraser ${ }^{279}$, esse confronto social se deve às experiências políticas de uma coletividade pela luta de direitos historicamente marginalizados.

A identidade étnica, então, é um relevante elemento para o processo de desenvolvimento social, uma vez que exige um reconhecimento étnico mais integrado e sistemático das diversidades culturais, muito além do universal formalismo defendido pelos direitos humanos para a garantia de preceitos fundamentais etnodesenvolvimentistas. É uma forma ideológica de representações coletivas que emergem nos contextos históricos de desenvolvimento social, buscando maior inserção nas políticas de integração cultural, social e política, relevantes para a consolidação da autodeterminação dos povos e jurisdição indígena.

A "fricção interétnica" é o núcleo fundante para a consolidação da identidade indígena porque questiona a compatibilização de representações étnicas entre o branco e o indígena nos processos de desenvolvimento social contemporâneo, marcado nitidamente por assimetrias histórias, conforme se observa na dominação dos "brancos" e sujeição dos "indígenas".

Suscita no processo democrático de participação social maiores debates étnicos para a consolidação dos direitos fundamentais, de modo a promover ações afirmativas que destaquem esse campo de investigação científica como um avanço na transformação social das minorias étnicas, pautada internacionalmente na

\footnotetext{
${ }^{279}$ FRASER, Nancy. Da redistribuição ao reconhecimento? Dilemas da justiça na era pós-socialista. In: SOUZA, Jessé. Democracia hoje: novos desafios para a teoria democrática contemporânea. Brasília, DF: UnB, 2001. p.10.
} 
Declaração das Nações Unidas sobre os Direitos dos Povos Indígenas e demais ditames constitucionais vigentes.

Quadro 3 - Relação da Declaração das Nações Unidas sobre os Direitos dos Povos Indígenas para a garantia dos direitos pluriétnicos e multiculturais.

\begin{tabular}{|c|c|c|}
\hline POVOS INDÍGENAS & $\begin{array}{c}\text { RELAÇÃO DO ESTADO E } \\
\text { OS POVOS INDÍGENAS }\end{array}$ & $\begin{array}{c}\text { RELEVÂNCIA } \\
\text { INTERNACIONAL }\end{array}$ \\
\hline $\begin{array}{l}\text { São iguais, porém } \\
\text { com direitos de serem } \\
\text { diferentes, já que são } \\
\text { considerados patrimônio } \\
\text { comum da humanidade. } \\
\text { São livres para } \\
\text { promover o seu } \\
\text { desenvolvimento, atenuando } \\
\text { as injustiças do seu processo } \\
\text { histórico de discriminação e } \\
\text { opressão social. } \\
\text { resursos naturais. } \\
\text { acontecimentos sobre seus } \\
\text { espaços originariamente } \\
\text { adquiridos, para que haja o } \\
\text { reforço e a manutenção do } \\
\text { desenvolvimento cultural em } \\
\text { rerras, territórios e }\end{array}$ & $\begin{array}{l}\text { Respeito } \\
\text { promoção de direitos } \\
\text { intrínsecos dos povos } \\
\text { indígenas derivam: } \\
\text { pelíticas, econômicas e } \\
\text { sociais; } \\
\text { suas tradições espirituais, de } \\
\text { sua história e sua concepção } \\
\text { de vida; } \\
\text { E Especialmente aos } \\
\text { direitos de suas terras, } \\
\text { territórios e recursos. }\end{array}$ & $\begin{array}{l}\text { Respeito e } \\
\text { promoção de direitos } \\
\text { dos povos indígenas, } \\
\text { firmados em tratados, } \\
\text { acordos e arranjos } \\
\text { constitutivos com o } \\
\text { Estado. } \\
\text { Caráter } \\
\text { internacional } \\
\text { tratados, acordos } \\
\text { outros arranjos } \\
\text { constitutivos entre o } \\
\text { Estado e os povos } \\
\text { indígenas. }\end{array}$ \\
\hline $\begin{array}{l}\text { Reconhecimento } \\
\text { dos direitos coletivos e dos } \\
\text { povos indígenas. }\end{array}$ & $\begin{array}{l}\text { Relações entre } \\
\text { Estados e povos indígenas } \\
\text { estão baseadas na justiça, }\end{array}$ & $\begin{array}{l}\text { Condena } \\
\text { doutrinas, políticas e } \\
\text { práticas baseadas na }\end{array}$ \\
\hline
\end{tabular}




\begin{tabular}{|c|c|c|}
\hline $\begin{array}{l}\text { A situação dos } \\
\text { povos indígenas varia } \\
\text { segundo regiões e países, } \\
\text { significando particularidades } \\
\text { nacionais e regionais } \\
\text { históricas e culturais. }\end{array}$ & $\begin{array}{l}\text { Ênfase para as } \\
\text { relações de direitos } \\
\text { humanos, de consulta e } \\
\text { cooperação com os povos } \\
\text { indígenas. }\end{array}$ & $\begin{array}{l}\text { superioridade de um } \\
\text { povo ou pessoa sobre } \\
\text { outras em observância } \\
\text { ao princípio da } \\
\text { isonomia. } \\
\text { Repudia } \\
\text { injustiças histórias } \\
\text { devido ao processo de } \\
\text { colonização } \\
\text { ocupação de terras, } \\
\text { territórios e recursos } \\
\text { naturais em áreas } \\
\text { indígenas. }\end{array}$ \\
\hline
\end{tabular}

Fonte: Análise social comparativa desenvolvida pela autora, 2017.

Axel Honneth ${ }^{280}$ descreve que um reconhecimento deve obedecer a algumas condições subjetivas de que os sujeitos necessitam para se sentirem protegidos na sua autorrealização, como o direito e a solidariedade.

Essa proteção significa o dever que cada cidadão possui de respeitar o direito do outro mediante sua própria conduta. E para ser eficaz, deve ser organizada institucional e publicamente.

\subsection{Avanços e retrocessos para a consolidação dos direitos indígenas no Estado Democrático de Direito}

Povos indígenas evidenciam que estes possuem o direito de promover, desenvolver e manter suas estruturas institucionais e seus próprios costumes, espiritualidade, tradições, procedimentos, práticas e, quando existam, costumes ou sistemas jurídicos, em conformidade com as normas internacionais de direitos humanos, além de possuírem o direito de determinar as responsabilidades dos indivíduos para com suas comunidades.

${ }^{280}$ HONNETH, Axel. Luta por reconhecimento: a gramática moral dos conflitos sociais. Tradução de Luiz Repa. São Paulo: Editora 34, 2003. p. 12. 
Dessa maneira, ocorre o reconhecimento dos sistemas jurídicos e da jurisdição própria dos povos indígenas nas esferas internacional e nacional para o exercício de seus direitos pluriétnicos e o acesso à justiça sem impedimento do ordenamento jurídico estatal.

A manutenção de direitos aos povos indígenas e sua aplicação nos sistemas jurídicos exigem o exercício de uma jurisdição própria, que tem sido reconhecida pelos instrumentos internacionais de proteção às minorias étnicas, como a ONU e demais órgãos de proteção aos direitos humanos, bem como nas normas e jurisprudências de muitos Estados.

Nesse sentido, a Convenção n. 169 da Organização Internacional do Trabalho (OIT) estabelece que os costumes e o direito consuetudinário dos povos indígenas devem ser levados em consideração pelos Estados na aplicação de sua legislação nacional, como a Constituição Federativa do Brasil.

Vale salientar que o direito indígena é uma expressão cultural. O artigo 34 da Declaração das Nações Unidas sobre os Direitos dos Povos Indígenas explicitamente o vincula a tradições, costumes, procedimentos e práticas jurídicas próprias dos povos indígenas, e ao longo da humanidade vem sendo cada vez mais consolidado no ordenamento jurídico internacional.

O reconhecimento da jurisdição do direito cultural indígena possui fundamento no artigo 35 da Declaração das Nações Unidas sobre os Direitos dos Povos Indígenas, ao declara estes podem determinar as responsabilidades dos indivíduos para suas comunidades, o que pressupõe a existência de normas e formas de organização interna de uma comunidade indígena para a delegação de responsabilidades que podem abranger tanto os aspectos culturais como os mecanismos jurisdicionais internos.

A vinculação entre o direito e a justiça indígena em relação aos aspectos culturais, portanto, consolida um repensar da forma como o direito tem sido tradicionalmente entendido e seus reflexos sobre o Direito Internacional dos direitos humanos.

O direito cultural precisa ser considerado além de um direito individual, mas de uma coletividade étnica amparada nos preceitos internacionais constituídos. Não pode ser concebida na sociedade moderna somente como um conjunto de práticas herdadas que devem ser respeitadas pelo Estado, mas, sobretudo, como um sistema de organização interna em diversos níveis, cujo objetivo é assegurar os direitos 
fundamentais das minorias étnicas, historicamente marginalizadas no processo de desenvolvimento social.

Esses sistemas étnicos não somente determinam a forma de exercer os direitos por parte dos membros da comunidade, como também geram inúmeras implicações no funcionamento do sistema político e jurídico do Estado.

O reconhecimento do direito e a jurisdição dos povos indígenas que historicamente o Estado tem monopolizado expressam novos horizontes no ordenamento jurídico por meio de modelos multiculturais de sociedade baseados em princípios da autonomia e do pluralismo jurídico.

Como o direito à cultura é de caráter eminentemente coletivo, por isso é considerado um direito de acesso à justiça dos povos indígenas, é indispensável, para sua existência, bem-estar e desenvolvimento social como povo.

O reconhecimento internacional de direitos dos povos indígenas também garante seus direitos à terra, ao território e aos recursos naturais, estabelecendo uma relação de continuidade entre a história das minorias étnicas e a realidade contemporânea desses povos para a consolidação de um direito permanente e dinâmico.

Portanto, a Declaração das Nações Unidas sobre os Direitos dos Povos Indígenas estabelece, em seu artigo 11281, o direito dos povos indígenas de manter, proteger e desenvolver suas manifestações passadas, presentes e futuras de suas culturas mediante normas e práticas jurídicas que atendam aos preceitos multiculturais das populações indígenas.

Direito e jurisdição, dessa maneira, são expressões de autonomia ou autogoverno dos povos indígenas reforçados pelos artigos $4^{\circ}$ e $5^{\circ}$ da Declaração 282 : o direito à autodeterminação nas questões relacionadas aos assuntos internos e

${ }^{281}$ DECLARAÇÃO das Nações Unidas sobre os Direitos dos Povos indígenas. Art.11º: 1. Os povos indígenas têm o direito de praticar e revitalizar suas tradições e costumes culturais. Isso inclui o direito de manter, proteger e desenvolver as manifestações passadas, presentes e futuras de suas culturas, tais como sítios arqueológicos e históricos, utensílios, desenhos, cerimônias, tecnologias, artes visuais e interpretativas e literaturas. 2. Os Estados proporcionarão reparação por meio de mecanismos eficazes, que poderão incluir a restituição, estabelecidos conjuntamente com os povos indígenas, em relação aos bens culturais, intelectuais, religiosos e espirituais de que tenham sido privados sem o seu consentimento livre, prévio e informado, ou em violação às suas leis, tradições e costumes.

282 DECLARAÇÃO das Nações Unidas sobre os Direitos dos Povos indígenas. Art. $4^{\text {o: }}$ Os povos indígenas, no exercício do seu direito à autodeterminação, têm direito à autonomia ou ao autogoverno nas questões relacionadas a seus assuntos internos e locais, assim como a disporem dos meios para financiar suas funções autônomas. Art. $5^{\circ}$ : Os povos indígenas têm o direito de conservar e reforçar suas próprias instituições políticas, jurídicas, econômicas, sociais e culturais, mantendo ao mesmo tempo seu direito de participar plenamente, caso o desejem, da vida política, econômica, social e cultural do Estado. 
locais ocorre o reconhecimento do direito para a conservação e reforço de suas próprias instituições políticas, jurídicas, sociais e culturais. A referência nas instituições jurídicas inclui tanto as normas como os órgãos de jurisdição indígenas.

Implicações práticas da autodeterminação encontradas nos sistemas jurídicos indígenas vinculam o exercício da jurisdição para assuntos internos e locais, em que a definição de assuntos internos está na própria definição de pertencimento das comunidades indígenas, concebida pela Declaração das Nações Unidas sobre os Direitos dos Povos Indígenas como um direito autônomo das próprias comunidades, de acordo com suas tradições e costumes para a consolidação da justiça indígena.

A jurisdição dos povos indígenas sobre os assuntos internos das comunidades étnicas implica, necessariamente, uma articulação de coordenação e cooperação com a justiça estatal. Existe, assim, um reconhecimento do direito e das instituições indígenas ao princípio da autonomia e pluralismo jurídico, regulado pelos ditames do Direito Internacional.

Nesse sentido, a Convenção n. 169 da Organização Internacional do Trabalho (OIT) se refere ao estabelecimento de procedimentos para solucionar conflitos decorrentes desse reconhecimento das culturas e instituições dos povos indígenas, os qualis devem ser levados em consideração para a garantia dos direitos indígenas nas estruturas de organização dos Estados.

Com o avanço dos direitos indígenas no âmbito internacional, o exercício de sua própria jurisdição e de seus direitos coletivos gera a importância de acomodá-los nas estruturas estatais, que tem identificado a necessidade de desenvolver mecanismos de coordenação entre o sistema jurídico positivo e o sistema jurídico indígena ${ }^{283}$.

Essa necessidade se encontra reconhecida nas Constituições da Colômbia ${ }^{284}$, do Equador ${ }^{285}$ e do México ${ }^{286}$, que têm dado relevante consideração para a integração e a coordenação de ambas as jurisdições.

283 GARCIA, David Bondia. Muñoz, Manuel Ramiro (Coord.). Víctimas invisibles, conflito armado y resistencia civil en Colombia. Barcelona: Huygens Editorial, 2009. p. 272.

284 CONSTITUCIÓN Política de Colombia. Disponível em: <http://www.corteconstitucional. gov.co/inicio/Constitucion\%20politica\%20de\%20Colombia\%20-\%202015.pdf>. Acesso em: 08 de maio de 2017.

285 CONSTITUCIÓN del Ecuador. Disponível em: <http://www.asambleanacional.gov.ec/documentos /constitucion_de_bolsillo.pdf >. Acesso em: 08 maio 2017.

286 CONSTITUCIÓN Política de los Estados Unidos Mexicanos. Disponível em: <http://www.diputados.gob.mx/LeyesBiblio/pdf/1_240217.pdf>. Acesso em: 08 maio 2017. 
Na prática, a efetividade dos direitos indígenas ainda está sendo consolidada, pois o Estado ainda possui inúmeras dificuldades para melhor atender às demandas de base étnica, considerada relevante fundamento para o amplo reconhecimento da justiça indígena. Por isso, o desenvolvimento social que considera a jurisdição indígena integrada com a jurisdição estatal encontra-se em processo de construção para a América Latina, porém em alguns países, como a Colômbia têm desenvolvido a jurisdição indígena na jurisprudência da Corte Constitucional Colombiana ${ }^{287}$.

Essa é uma relevante consideração para a integração da justiça indígena como fonte do direito, pois o sistema de justiça estatal consiste na sua interligação, baseada no reconhecimento do pluralismo jurídico, sendo necessário o estabelecimento de critérios multiculturais para a incorporação das decisões que envolvem a justiça indígena e o direito estatal, bem como para a solução de conflitos normativos que envolvem ambos os sistemas.

No artigo 34 da Declaração das Nações Unidas sobre os Direitos dos Povos Indígenas ${ }^{288}$, há menção às normas de direitos humanos asseguradas aos povos indígenas para a garantia de seus direitos fundamentais estabelecidos na Carta das Nações Unidas, na Declaração Universal dos Direitos Humanos e nas demais normativas internacionais.

Essas normas regulam o devido processo legal para a justa aplicação no ordenamento jurídico, com base nos princípios internacionalmente consolidados, que também gozam as pessoas sujeitas ao exercício da jurisdição indígena.

A harmonia entre o direito e as práticas de jurisdição indígena com as normas de direitos humanos é imprescindível para a consolidação do acesso à justiça.

287 JULGADO del Corte Constitucional de Colombia. Referência: Expediente T-5.120.337, de 7 de fevereiro de 2017. Acción de tutela interpuesta por Martín Narváez Gómez en calidad de Capitán del resguardo indígena Carijona de Puerto Nare (Guaviare) y otro, contra la Presidencia de la República y otros. Disponível em: <http://www.corteconstitucional.gov.co/relatoria/2017/t-080-17.htm>. Acesso em: 15 maio 2017.

288 DECLARAÇÃO das Nações Unidas sobre os Direitos dos Povos Indígenas. Artigo 34: Os povos indígenas têm o direito de promover, desenvolver e manter suas estruturas institucionais e seus próprios costumes, espiritualidade, tradições, procedimentos, práticas e, quando existam, costumes ou sistema jurídicos, em conformidade com as normas internacionais de direitos humanos. Disponível: <http://www.un.org/esa/socdev/unpfii/documents/DRIPS_pt.pdf>. Acesso em: 9 maio 2017. 
Por outro lado, no artigo 9º da Convenção 169 Organização Internacional do Trabalho (OIT) 289 afirma-se que a submissão da jurisdição indígena às normas de direitos humanos não é uma aplicação automática ao direito interno, mas de acordo com a compatibilidade do sistema jurídico nacional e internacional vigente.

Nesse sentido, a compatibilidade entre o Direito Internacional de direitos humanos e a justiça indígena deve ser regida pelos princípios gerais da autodeterminação, da autonomia e do respeito a cultura indígena, que norteiam a Declaração das Nações Unidas sobre os Direitos dos Povos Indígenas.

As normas de direitos humanos devem ser interpretadas de acordo com os próprios sistemas jurídicos indígenas, que se baseiam nos preceitos pluriétnicos e multiculturais para a consolidação dos direitos indígenas.

Essa coordenação entre a jurisdição estatal e a jurisdição indígena constitui um sistema dinâmico que se desenvolve diante de diversas realidades sociais no mundo contemporâneo das minorias étnicas historicamente marginalizadas e que se respaldam esses preceitos constitutivos para desfrutar seus direitos individuais e coletivos.

Uma das manifestações mais relevantes de reconhecimento do direito indígena está baseada nos direitos relativos à terra, territórios e recursos naturais. Essa consideração encontra apoio no artigo 26 da Declaração das Nações Unidas sobre os Direitos dos Povos Indígenas, que reconhece o direito dos povos indígenas sobre as terras, territórios e recursos que possuem em decorrência de sua ocupação tradicional da propriedade para subsistência.

Já o artigo 27 da Declaração das Nações Unidas sobre os Direitos dos Povos Indígenas deve ser analisado como um reconhecimento do direito indígena ao direito de propriedade tradicional, posse e uso dos recursos naturais, em que a forma de ocupação tradicional possui um vínculo histórico entre os povos indígenas e seus territórios.

\footnotetext{
${ }^{289}$ DECRETO n. 5.051, de 19 de abril de 2004. Promulga a Convenção n. 169 da Organização Internacional do Trabalho - OIT sobre Povos Indígenas e Tribais. Art. $9^{\circ}$ : 1 . Na medida em que isso for compatível com o sistema jurídico nacional e com os direitos humanos internacionalmente reconhecidos, deverão ser respeitados os métodos aos quais os povos interessados recorrem tradicionalmente para a repressão dos delitos cometidos pelos seus membros. Disponível em: <http://www.planalto.gov.br/ccivil_03/_ato20042006/2004/decreto/d5051.htm>. Acesso em: 9 maio 2017.
} 
O reconhecimento desse vínculo possui efeitos jurídicos por parte do Estado, porque os povos indígenas têm historicamente ocupado seus territórios e tradicionalmente possuem a consciência do "pertencimento" desses espaços para a proteção e o desenvolvimento de suas práticas interculturais ${ }^{290}$ ou sociais de subsistência.

O direito à identidade cultural assumiu uma ampla dimensão por ser considerado essencialmente um direito fundamental, inerente à personalidade jurídica do indivíduo como sujeito de Direito Internacional.

A Corte Interamericana de Direitos Humanos tem proferido sentenças de bastante relevância pautadas no direito à identidade cultural. Por exemplo, o Caso em El Salvador, no julgamento de Hermanas Serrano ${ }^{291}$, em que se observou a relevância do direito cultural para assegurar os direitos indígenas no território e sua abrangência para os interesses de uma coletividade étnica.

Outro julgamento de bastante relevância ocorreu no caso das Comunidades indígenas Yakye Axa e Sawhoyamaxa no Paraguai292, que também ilustra a violação do direito à identidade cultural indígena e sua relação com suas terras tradicionais. Eles foram destituídos forçadamente do território, sobrevivendo às margens do processo de desenvolvimento social refletido na mais grave exclusão social|293.

Evidenciou-se o direito à vida como dignidade da pessoa humana, destacando-se aspectos étnicos variados, como patrimônio cultural, histórico, religioso, ideológico, político, social e familiar de uma minoria étnica, pois não houve apenas a violação da identidade cultural de uma comunidade indígena, mas a lesão da identidade pessoal de cada membro que a compõe.

${ }^{290}$ DECRETO N. 6.177, de $1^{\circ}$ de agosto de 2007. Promulga a Convenção sobre a Proteção e Promoção da Diversidade das Expressões Culturais, assinada em Paris, em 20 de outubro de 2005. "Proteção" significa a adoção de medidas que visem à preservação, salvaguarda e valorização da diversidade das expressões culturais. "Interculturalidade" refere-se à existência e interação eqüitativa de diversas culturas, assim como à possibilidade de geração de expressões culturais compartilhadas por meio do diálogo e respeito mútuo. Disponível em: <http://www. planalto.gov.br/ccivil_03/_ato2007-2010/2007/decreto/d6177.htm> Acesso em: 09 maio de 2017.

${ }^{291}$ CORTE Interamericana del Derechos Humanos. Caso de las Hermanas Serrano Cruz Vs. El Salvador. Sentencia de 1 de marzo de 2005. Disponível em: 〈http://www. corteidh.or.cr/docs/casos/articulos/seriec_120_esp.pdf〉. Acesso em: 16 maio 2017.

${ }^{292}$ CORTE Interamericana del Derechos Humanos. Caso Comunidad Indígena Sawhoyamaxa Vs. Paraguay. Sentencia de 29 de marzo de 2006. Disponível em: <http://www.corteidh.or.cr/ docs/casos/articulos/seriec_146_esp2.pdf>. Acesso em: 16 maio 2017.

293 TRINDADE, Antônio Augusto Cançado. El ejercicio de la función judicial internacional: memorias de la Corte Interamericana de Derechos Humanos. 3. ed. Belo Horizonte: Del Rey, 2016. p. 95. 
Essa decisão condenou o Estado do Paraguai por violação aos direitos à vida, propriedade, garantias judiciais e proteção judicial, determinando que fossem demarcadas as terras indígenas e providos os serviços básicos necessários à sobrevivência da comunidade indígena Yakye Axa.

Essa sentença possuiu reflexos positivos na concepção do direito à vida, não se limitando apenas à privação arbitrária, mas também às demandas inerentes ao efetivo gozo de uma vida digna, que se realiza na garantia do direito à identidade cultural.

Outro aspecto considerado pela Corte consiste no caráter dinâmico e evolutivo para as interpretações que ampliem os direitos humanos, pois no caso, também, houve delineamentos importantes acerca da propriedade coletiva de seus ancestrais indígenas, visando assegurar a identidade cultural e a transmissão dos valores, crenças, línguas, rituais e costumes étnicos para as gerações futuras, bem como sua relação com a natureza e com o direito consuetudinário.

Essa relação dos povos indígenas com as terras tradicionais ocupadas por seus ancestrais consiste em uma das características etnográficas utilizadas pelas minorias étnicas para se identificar, atuar e agir com o devido reconhecimento indígena junto ao grupo, como forma de pertencimento e empoderamento cultural.

Esse vínculo de reconhecimento de direito aos povos indígenas sobre suas terras, territórios e recursos naturais, integrado ao reconhecimento normativo indígena, tem sido expressamente reconhecido pela Corte Interamericana de Direitos Humanos, com base na sentença do Caso Awas Tingni em Nicarágua ${ }^{294}$. Nessa sentença, a Corte Interamericana estabeleceu que a propriedade indígena sobre suas terras tradicionalmente ocupadas baseia-se nos costumes e tradições dessas minorias étnicas, através do direito consuetudinário que estabelece o título de propriedade das terras aquelas populações indígenas, que historicamente ocuparam o espaço, tiveram seus direitos originários violados sobre o território e seus preceitos fundamentais de cidadania cultural desobedecido pelo sistema de integração social.

${ }^{294}$ CORTE Interamericana del Derechos Humanos. Caso Comunidad Mayagna - Awas Tingni X Nicarágua. Sentença de 31 de agosto de 2001 (série C, n. 79). Disponível em: <http://www.corteidh.or.cr/docs/casos/articulos/Seriec_79_esp.pdf>. Acesso em: 9 maio 2017. 
Esse caso da Corte Interamericana de Direitos Humanos ampliou o entendimento jurisprudencial acerca das violações dos direitos indígenas, podendo também ser aplicado nos casos de conflitos de propriedade contra terceiros ou em relação à exploração dos recursos naturais presentes em território indígena.

A vinculação realizada entre direito ao território e direito indígena deriva de uma necessidade estatal de melhor sanear o reconhecimento da demarcação e a titulação das propriedades indígenas desenvolvendo maiores diálogos entre os diversos atores sociais envolvidos no processo de consolidação dos direitos indígenas.

O reconhecimento e a proteção dos territórios indígenas devem levar em consideração o respeito aos costumes, tradições e os sistemas jurídicos étnicos que defendem os direitos indígenas consubstanciados nos valores, usos, costumes e tradições desses povos, como importante núcleo para a consolidação da autodeterminação dos povos e a superação dos modelos clássicos da propriedade agrária dos Estados, que muito contribuem para o latifúndio e ampliação dos conflitos agrários na sociedade moderna em detrimento das minorias étnicas ${ }^{295}$.

Nesse sentido, tradicionalmente, o sistema de justiça indígena tem operado com relativa resistência para o reconhecimento do Estado em grande parte, pois o que se observa é um reconhecimento das práticas indígenas aquém de um pleno reconhecimento de direito para a consolidação das instituições indígenas, como marco de sua autonomia e de seu pluralismo jurídico.

Isso conduz a uma estrutura tradicional que subordina a jurisdição indígena à estrutura estatal, fazendo com que os preceitos assegurados pela Declaração das Nações Unidas sobre os Direitos dos Povos Indígenas e demais dispositivos constitucionais vigentes não sejam atendidos no processo de desenvolvimento social indígena, pois esses grupos vulneráveis já sofrem discriminações, preconceitos e negativos estigmas historicamente construídos acerca dessas minorias étnicas, hoje considerados agentes de desenvolvimento social e cultural pelo Direito Internacional Contemporâneo.

É necessário refletir interculturalmente a consolidação do direito indígena no ordenamento jurídico positivo, e para isso deve-se transpor a lógica e o dinamismo positivo do ordenamento jurídico, em que se delineia um valor jurídico vinculante a

${ }^{295}$ MALHEIROS, Antônio Carlos; BACARIÇA, Josephina; VALIM, Rafael (Coord.). Direitos humanos: desafios e perspectivas. Belo Horizonte: Fórum, 2011. p.67. (Coleção Fórum Direitos Humanos, 3). 
um texto normativo, sendo a resposta de juristas positivistas ao valor da Declaração das Nações Unidas sobre o Direito dos Povos Indígenas.

Por outro lado, evidencia-se a potencial realidade do pluralismo jurídico nos debates e entrelinhas do direito indígena, exigindo, portanto, do aparato estatal maiores indicadores e variantes para a consolidação da justiça pluriétnica e multicultural, como valores, tradições e costumes étnicos.

Evidenciar outras lógicas jurídicas possíveis, portanto, supõe um repensar de como se define o sistema de fontes do direito positivo em relação ao valor, à validade, à vinculação e à obrigatoriedade, os quais possuem reflexos diretos na universalidade dos direitos humanos.

A outorga do direito consuetudinário reconhece na perspectiva dos direitos indígenas um sistema jurídico étnico no sistema jurídico do positivado, abrindo espaço para diversos agentes sociais, como os povos indígenas, que poderão inserir conteúdos e consequências concretas para a efetividade de direitos consagrados na Declaração das Nações Unidas sobre o Direito dos Povos Indígenas.

Nesse sentido, a inserção do pluralismo jurídico ao conteúdo dos direitos econômicos e sociais indígenas é imprescindível para os operadores do direito e para a sociedade de modo geral, a fim de assegurar o respeito ao princípio da não discriminação por qualquer motivo de raça, cor, sexo, idioma, religião, opinião política, origem nacional ou racial, posição econômica ou qualquer outra condição social.

Outro aspecto relevante a ser considerado no âmbito das obrigações dos Estados corresponde às medidas legislativas para se fazerem efetivos os direitos econômicos e sociais dos povos indígenas, conforme preceituado nos Pactos Internacionais de Direito Humanos.

O repensar das fontes do direito em relação aos povos indígenas implica a consideração dos usos e costumes do direito consuetudinário, como fundamento jurídico essencial para o reconhecimento do valor e validade do direito indígena. 


\section{CONCLUSÃO}

Nesta tese, ilustrou-se a importância das Nações Unidas para a autodeterminação dos povos indígenas como uma proposta de cidadania multicultural diferenciada não apenas para a preservação das diversas formas culturais, mas como um acréscimo de oportunidades para a construção da jurisdição indígena, a fim de que os seus membros na sociedade atual sejam sujeitos ativos de direito, resguardando as condições mínimas para o efetivo atendimento das políticas de interesse social indígena. Diante do exposto, conclui-se:

A) O princípio da autodeterminação dos povos é um exercício de análise jurídica que nos permite estudar o processo de formulação e implementação de uma norma jurídica internacional. Além disso, essa análise evidencia uma série de questões ligadas aos fundamentos e às diversas áreas de regulamentação do Direito Internacional Público. Portanto, o estudo do princípio da autodeterminação não serve somente como uma consideração particularizada de uma norma jurídica internacional, mas também pode ser uma maneira de abordar o estudo de uma pluralidade de conceitos no Direito Internacional Público.

Nesse sentido, o estudo do princípio da autodeterminação dos povos abrange o processo de formulação da norma, como o exame dos principais elementos presentes em seu conteúdo e aplicação.

Com base nos valores da liberdade e da igualdade, a formulação jurídica do princípio da autodeterminação dos povos é fundada sobre um princípio de natureza política que se desenvolveu na Idade Moderna e, no marco do Direito Internacional Contemporâneo, esse princípio se tornou uma norma jurídica internacional.

O princípio da autodeterminação dos povos incorporado pela Carta das Nações Unidas iniciou um processo de desenvolvimento progressivo em que a prática dos Estados, as Organizações Internacionais e os pronunciamentos de jurisprudência internacional têm contribuído para esclarecer e completar o conteúdo desse princípio.

Como resultado desse processo, o conteúdo jurídico do princípio da autodeterminação compreende o reconhecimento de uma série de direitos e obrigações aplicáveis aos povos e a determinado território. 
A prática de Estados, das Organizações Internacionais e da jurisprudência dos Tribunais revela a existência e o funcionamento dos diferentes mecanismos de aplicação das regras do Direito Internacional, com base no conteúdo jurídico da autodeterminação dos povos.

$\mathrm{Na}$ prática, o princípio da autodeterminação enfrenta novos desafios da sociedade moderna e do Direito Internacional. Sua aplicação está relacionada à violação da integridade territorial dos Estados, à expansão da democracia como critério de legitimidade democrática e ao ressurgimento dos nacionalismos. Esses são alguns dos desafios que a autodeterminação deve responder.

A revisão deste marco normativo que se estende desde a concepção até a aplicação do princípio da autodeterminação exige o estudo dos conceitos e instituições de Direito Internacional Público. O conteúdo da autodeterminação envolve a consideração de questões da formação histórica e a estrutura do Direito Internacional, como a criação de normas jurídicas internacionais, a subjetividade e a responsabilidade internacional.

Abarca, também, diversas áreas de regulação do Direito Internacional, como a proteção internacional dos direitos humanos, a soberania territorial e a proibição da ameaça ou uso da força armada, conforme se observou no caso da Declaração Unilateral de Independência no Kosovo.

A análise do conteúdo do princípio da autodeterminação dos povos serve para aproximar o estudo dos principais conceitos de minorias étnicas e as instituições de Direito Internacional Público.

B) A dinâmica conceitual e a abrangência do princípio da autodeterminação dos povos evidenciam que a consolidação dos direitos humanos utilizando esse instrumento jurídico pauta-se em constantes mudanças ao longo do processo histórico de desenvolvimento social. Por isso, a autodeterminação dos povos também tem sido utilizada como princípio estrutural do Direito Internacional para assegurar os direitos dos povos e a expansão dos direitos humanos no âmbito internacional, ilustrando sua dinâmica e relevância jurídica que se constrói gradativamente no ordenamento jurídico internacional para assegurar os direitos das minorias étnicas e fomentar as relações de amizade entre as nações.

O direito e a prática internacional têm demonstrado que, em relação à erradicação da dominação colonial, a autodeterminação dos povos constitui uma norma imperativa que gera obrigações para a comunidade internacional. 
Dessa maneira, a Declaração das Nações Unidas sobre os Direitos dos Povos Indígenas busca as bases para a relação entre os Estados e os povos indígenas, principalmente pelo reconhecimento de seus direitos individuais e coletivos, incluindo os direitos econômicos, sociais e culturais, que, além de ser considerado um relevante fundamento para a consolidação da autodeterminação dos povos, fortalece o direito dos povos para decidirem seus interesses pluriétnicos e multiculturais.

Evidenciou-se, assim, um modelo de cidadania multicultural diferenciada que superasse os limites da cidadania de tradição liberal, baseada numa forma débil de representação política, social e cultural das minorias étnicas, pois qualquer forma de identidade para o exercício da cidadania é fator intrínseco de representação.

A identidade étnica, ainda que conflitiva com os outros sistemas previamente existentes, possui traços nitidamente coloniais de resistência ao direito dos povos, com diferentes aspectos culturais, conduzindo a uma revisão do conceito de cidadania às minorias étnicas na atualidade.

Isso evidencia, de algum modo, a expressão da evolução em relação à proteção das minorias étnicas, bem como a superação de barreiras historicamente construídas para a efetiva consolidação dos direitos aos povos indígenas.

No âmbito internacional, esses aspectos antes resumidos às fronteiras dos Estados, atualmente demonstram uma relativa evolução do Direito Internacional para a construção e a consolidação do direito à autodeterminação dos povos.

C) O direito à autodeterminação e o princípio da integridade territorial não são considerados contraditórios, mas preceitos legalmente constituídos e plenamente válidos para a consagração de direitos dos povos, que promovem o compromisso Estatal como mecanismo de proteção e promoção das populações indígenas, estabelecidas no contexto das organizações internacionais e demais âmbitos existentes na defesa dos direitos das minorias étnicas.

A vigência do princípio da integridade territorial dos Estados no Direito Internacional para a consolidação da autodeterminação dos povos mantém-se preservada, porém essa prerrogativa estatal distancia juridicamente o debate de que a execução da autodeterminação conduz à formação de novos Estados a partir da secessão territorial. 
A autodeterminação dos povos preserva os pressupostos constitucionais vigentes, porém fomenta, de algum modo, a divisão estatal por parte das minorias que habitam o território e que nutrem as possibilidades de que sua opressão no sistema atualmente delineado seja mitigada por meio desse princípio, possibilitando a construção de seu autogoverno e seus direitos especiais de representação étnica.

Esse princípio, atualmente, ainda possui grandes obstáculos para se alcançar no formato do direito delineado, pois a autodeterminação dos povos ainda não está completamente inserida na relação de ações legais previstas no direito positivo atual.

Apesar de a Declaração das Nações Unidas não atender integralmente às reivindicações do movimento indígena, pode ser considerada um importante avanço para a construção e a consolidação da autodeterminação na modalidade interna dos direitos indígenas, não devendo ser interpretada contra o princípio da integridade territorial dos Estados.

Nesse sentido, a autodeterminação dos povos indígenas pode servir para mitigar a tensão entre direito estatal e direito do povo, principalmente no que se refere à questão da democracia interna e dos direitos humanos, buscando um autogoverno, uma cidadania multicultural, bem como os direitos especiais de representação étnica, de modo que os interesses indígenas sejam levados em consideração para a defesa de suas aspirações culturais como fundamento da sua autonomia no Estado Democrático de Direito.

A consolidação dessa conquista está baseada no direito dos povos no âmbito internacional, permitindo a incorporação de novos sujeitos de direito, como os povos sem um governo próprio, os quais buscam por meio desse reconhecimento pluriétnico e multicultural o meio de materializar normativamente os direitos de grupos com os diversos enfoques étnicos, linguísticos ou religiosos dentro de uma mesma fronteira estatal.

É necessário compensar essa herança histórica, que culminou nos efeitos negativos decorrentes da discriminação sofrida pelos povos indígenas estigmatizados em grande parte como minorias marginalizadas e inferiores.

$O$ fomento de ações afirmativas por meio da igualdade de reconhecimento às minorias étnicas e maior participação social na defesa de seus interesses econômicos, sociais e culturais contribui para a consagração do direito à autodeterminação dos povos. 
Além disso, o fomento da liberdade de expressão e o acesso dos membros que constituem as minorias étnicas nos espaços públicos asseguram a consolidação de práticas sociais e a construção de valores coletivos, mediante o reconhecimento dos interesses pluriétnicos e multiculturais estabelecido por meio de um diálogo intercultural, imprescindível para a autodeterminação dos povos indígenas.

Assim, a autodeterminação dos povos integra uma das mais valiosas realizações para a humanidade e a comunidade internacional, após o advento da ONU.

D) O reconhecimento da diversidade cultural constitui um imperativo de respeito à dignidade de todo ser humano, de acordo com os preceitos estabelecidos pela UNESCO, pois sua consolidação no Estado Democrático exige não apenas o reconhecimento e proteção da diversidade cultural do seu povo, mas também a implementação de mecanismos eficientes de integração das políticas sociais de desenvolvimento que atendam aos interesses dessas minorias étnicas como agentes de desenvolvimento social.

E) A titularidade dos povos à autodeterminação é identificada atendendo à condição jurídica do território sobre a qual se assentam e se projetam o conteúdo jurídico da aplicação desse direito. Isso explica as características da delimitação e da natureza jurídica do território, que condicionam não somente a identificação dos povos titulares da autodeterminação, mas também o conteúdo e o exercício dos direitos que lhes são concedidos.

Os povos titulares do direito à autodeterminação são identificados, portanto, com base na condição jurídica do território sobre o qual se assentam e sobre o qual se projetam o conteúdo jurídico e a aplicação do direito. Portanto, a delimitação e a natureza jurídica do território condicionam de maneira essencial o conteúdo e aplicação da autodeterminação, tanto no que se refere aos povos que vivem em territórios dependentes e aqueles assentados no território de um Estado soberano e independente.

Assim, no que diz respeito aos territórios sob dominação colonial ou estrangeira, a natureza jurídica transitória da situação em que se encontram explica que o exercício da autodeterminação determina a condição jurídica internacional do território, que constitui, ao mesmo tempo, a base territorial do povo e um dos elementos constitutivos do Estado. 
Pelo princípio da igualdade de direitos e da autodeterminação dos povos, portanto, os princípios da igualdade soberana e proibição da ameaça ao uso da força armada exige que o exercício da autodeterminação respeite a unidade e a integridade territorial do Estado, pois o espaço em que se assenta o povo tem uma condição jurídica internacional, a fim de garantir que as pessoas possam exercer livremente os seus direitos.

F) O conteúdo e a aplicabilidade do princípio da autodeterminação serão compatíveis com o respeito aos demais princípios estruturais do Direito Internacional, baseado nos valores da liberdade e da igualdade, fundamentais para 0 reconhecimento e a proteção dos direitos humanos internacionais.

A doutrina internacionalista, as resoluções, a prática internacional e a jurisprudência descrevem o estudo da autodeterminação dos povos sob a perspectiva global, que pode ser interpretada pelo povo e invocada em qualquer instância do Poder Judiciário sua aplicação, dada sua compatibilidade com as demais normas do ordenamento jurídico internacional.

A autodeterminação dos povos é apresentada como uma norma jurídica cuja invocação concede ao povo o direito de expressar sua vontade no processo de desenvolvimento social. Nesse sentido, os valores de liberdade e igualdade inspiraram a formulação da autodeterminação no âmbito do Direito Internacional Contemporâneo, sendo que a liberdade se projeta na livre expressão da vontade do povo e a igualdade se concretiza na erradicação de todas as situações de dominação colonial ou estrangeira.

G) A aplicação da autodeterminação acontece normalmente pela livre expressão do povo para seu desenvolvimento social. E seu exercício abrange não somente a determinação de uma condição jurídica internacional do território, mas também o estabelecimento do regime e das instituições apropriadas para a determinação da sua condição política e de desenvolvimento econômico, social e cultural.

O exercício do direito à autodeterminação requer expressão pública e livre da vontade do povo no que concerne à determinação de sua condição e desenvolvimento social, traduzindo-se no estabelecimento de regimes e instituições apropriadas para o povo, de modo que possam delimitar seu desenvolvimento na ordem interna. 
H) A formulação jurídica da autodeterminação dos povos promoveu alterações em algumas áreas de regulação material do Direito Internacional vigente. Em primeiro lugar, a incorporação da autodeterminação pelos Pactos Internacionais de direitos humanos foi um passo decisivo na proclamação dos direitos coletivos e dos direitos de solidariedade.

Em segundo lugar, a formulação da autodeterminação dos povos influenciou significativamente o regime jurídico da aquisição e perda da soberania territorial no âmbito internacional.

Dessa forma, o desenvolvimento progressivo das normas de Direito Internacional sobre a autodeterminação evidencia uma importante evolução do Direito Internacional Humanitário.

I) Por fim, promover um diálogo intercultural e interinstitucional entre as minorias étnicas e a sociedade civil de modo neutro, amplo e democrático é fundamental para uma expressiva participação popular por meio de um código linguístico acessível a todos os participantes do diálogo jurídico, contribuindo grandiosamente para a promoção de uma sociedade plural e solidária que integre as diversas culturas e reconheça os direitos das minorias étnicas historicamente marginalizadas.

Dessa maneira, o pluralismo jurídico contribui para a vinculação, a validade e o sentido do direito, além do ordenamento positivado, porque é fundamental a compreensão do texto normativo nacional e internacional, além do arcabouço jurídico já existente, por meio de processos sociais de desenvolvimento transversais, capazes de multiplicar os procedimentos, os sujeitos de direito e os recursos para a proteção dos direitos indígenas, a partir da história que hoje nos constitui, que é a de repressão social e de novas oportunidades de desenvolvimento para as futuras gerações.

As instituições internacionais têm se fortalecido para a defesa dos direitos indígenas promovendo o Fórum Permanente sobre Questões Indígenas na ONU, além de fomentarem o crescente papel dos dispositivos jurídicos de supervisão para a proteção dos direitos humanos das minorias étnicas.

A Declaração das Nações Unidas sobre os Direitos dos Povos Indígenas, considerada um instrumento internacional de grande relevância para a consolidação da autodeterminação dos povos indígenas, ilustra outra lógica de construção do direito distinto daquele positivado na modernidade ocidental. 
Pressupõe, também, uma reinterpretação da universalidade concebida pelos direitos humanos em decorrência das inúmeras linguagens e iniciativas multiculturais que as populações indígenas escrevem em sua história, o que multiplica as formas de expressão e formalização dela de maneira individual ou coletiva para a garantia dos direitos indígenas.

Nesse sentido, a democracia possui uma narrativa peculiar no que tange à história dos povos indígenas, pois visa ampliar a esfera da justiça social e da democracia representativa como uma lógica inserida nos discursos do direito.

Por outro lado, a dinâmica mais moderna que se delineia quanto aos direitos indígenas baseia-se no direito dos povos além de uma dimensão jurídica, em que suas limitações históricas no processo de desenvolvimento social e seus direitos violados historicamente os marginalizaram. Suas lutas sociais, porém, consistem em mecanismos efetivos para o acesso à justiça e o exercício da cidadania.

Dessa maneira, a autodeterminação dos povos indígenas atende aos princípios dos direitos humanos consagrados no Direito Internacional para a construção de uma sociedade mais justa e democrática.

Os avanços realizados no Brasil para a defesa dos grupos minoritários e vulneráveis estão de acordo com as especificidades de cada sujeito de direito, impulsionado pelo sistema internacional de proteção dos direitos humanos para as minorias étnicas, conforme preceituam a Carta das Nações Unidas e a Declaração das Nações Unidas sobre o Direito dos Povos Indígenas, as quais constituem relevantes fundamentos para a construção e a consolidação da autodeterminação dos povos indígenas na sociedade contemporânea. 


\section{RECOMENDAÇÕES}

As respectivas recomendações foram construídas para a ampliação das políticas socioculturais de desenvolvimento, visando à consolidação dos preceitos internacionais estabelecidos na Declaração das Nações Unidas sobre os Direitos dos Povos Indígenas como um instrumento eficaz de luta social, combate às injustiças historicamente construídas e contra qualquer forma de discriminação que viole os preceitos internacionais que asseguram a consolidação dos direitos humanos universais para as minorias étnicas.

Dessa maneira, seria possível garantir o autorrespeito e a solidariedade aos grupos que buscam o reconhecimento de sua identidade como marca indelével para sua conquista político-social na modernidade pluriétnica e multicultural.

Para isso, o Poder Público precisa abordar de maneira adequada os ditames internacionais e constitucionais vigentes para o efetivo exercício de cidadania das populações indígenas.

O Estado deve ampliar os espaços democráticos de participação social, pois ainda vigora a democracia representativa com gestores pouco dispostos a dividir o poder de decisão para além da representação. Aos cidadãos deve ser atribuída a decisão nas políticas públicas de maneira democrática.

Canais de participação devem ser criados para os diversos atores sociais, porque com as privatizações e inúmeras reformas administrativas o Estado brasileiro reduziu sua capacidade de implementar políticas e efetivar direitos.

Firmemente assentada em torno de privilégios de diversas naturezas sociais, a elite econômica nas entranhas do poder impede que 0 Brasil atenda ao reconhecimento efetivo das diversidades étnicas e culturais existentes, como vetor fundante de inclusão e participação social no processo de desenvolvimento, reproduzindo, então, práticas colonialistas que impedem uma nação de realizar maiores projeções etnossociais.

O descumprimento de direitos sociais historicamente consolidados amplia e reproduz novamente as exclusões, marginalizações e segregações sociais já vislumbradas na história da sociedade moderna. 
Embora a participação social tenha sido ampliada com o advento da atual Constituição brasileira de 1988, ainda é considerada insuficiente para atender às demandas políticas, econômicas, sociais e culturais que envolvem, especialmente, as populações indígenas, inseridas na nítida estrutura desigual de poder.

A vigência de um ordenamento jurídico anacrônico, burocrático e instrumental, baseado em leis e direitos parcialmente cumpridos, enfraquece as políticas sociais de desenvolvimento e financimanento que objetivam maiores inclusões dos agentes sociais, historicamente marginalizados, como as minorias étnicas.

Essencialmente, no Brasil não há mecanismos participativos eficientes nos espaços de decisão das políticas públicas indígenas, tampouco uma jurisdição indígena específica que desburocratize as demandas sociais judicializadas, a fim de que os pleitos dessa natureza étnica não sejam morosos no atendimento da política social.

Um modelo de desenvolvimento social efetivo seria uma grande ferramenta no combate à pobreza e à vulnerabilidade econômica, social e cultural, promovendo uma relativa igualdade entre os diversos agentes sociais.

Sem inclusão econômica não há inclusão cultural de desenvolvimento conduzindo a uma ineficácia do acesso à justiça e participação democrática no poder. Assim, a inclusão social dos cidadãos na sociedade moderna promove igualdades concretas de capacidades no bojo das diferenças entre os povos, que deveriam impulsionar desenvolvimento e não exclusão social.

As relações internacionais de poder entre Estados ainda são insatisfatórias no combate à pobreza, ao processo de desenvolvimento social e à autodeterminação dos povos.

Deve-se pensar na inclusão social por meio de políticas descentralizadas e não hierárquicas que conduzem prioritariamente os interesses sociais, juntamente com os diversos interesses econômicos de cada Estado, mediante transferências de recursos sociais para a educação, a saúde e a cultura.

A promoção de uma educação universal com politicas sociais integradas com fundo de financiamento para uma previdência social diferenciada e isenção tributária para aqueles que historicamente estiveram na condição de vulnerabilidade teria o condão de mitigar as disparidades construídas no processo de globalização. 
A pobreza e a marginalização social devem ser repensadas como uma política social de inclusão e mola propulsora de desenvolvimento entre as nações, conduzido por um ordenamento jurídico dinâmico, objetivo, racional e inclusivo.

A pobreza afronta as bases principiológicas do Direito Internacional, que deve repensar os direitos sociais de inclusão das minorias étnicas dentro do seu arcabouço jurídico, de acordo com os preceitos inicialmente lançados pela Carta das Nações Unidas.

Finalmente, a Declaração das Nações Unidas sobre os Direitos dos Povos Indígenas deve ser desenvolvida pelos Estados nacionais além da internacionalização dos direitos pluriétnicos e multiculturais, mas da internalização das políticas inclusivas de desenvolvimento social, que garantam a efetividade universal dos direitos humanos das minorias étnicas, como pressupostos fundamentais para a construção e consolidação da autodeterminação dos povos indígenas. 


\section{REFERÊNCIAS}

\section{1) DOUTRINA}

ALEXY, Rober., Teoria de los derechos fundamentales. Madrid: Centro de Estudios Constitucionales, 1993. p. 386-387.

ANAYA, James S. Indigenous people in international law. Oxford: Oxford University Press, 2000.

ANDRÉS SÁENZ DE SANTA MARIA, Paz. El derecho internacional ante la intervención de la OTAN. In: GIRÓN, José. La intervención de la OTAN en la Répública Federal de Yugoslavia. Gijón: Silverio Cañada, 2002. p. 12.

. La libre determinación de los pueblos en la nueva sociedad internacional. In: CARDONA LLORENS. Jorge (Coord.). Cursos euromediterráneos bancaja de derecho internacional. Pamplona: Aranzadi, v. 1. 1997.

BARBOSA, Marco Antonio. Autodeterminação: direito à diferença. São Paulo: Plêiade; Fapesp, 2001.

. Direito Antropológico e terras indígenas no Brasil. São Paulo: Plêiade; FAPESP, 2001.

BARROSO, Luis Roberto. Igualdade perante a lei. Revista de Direito Público, São Paulo, v. 19, n. 78, 1986. .

BARTOLOMÉ, Miguel Alberto. Processos civilizatórios, pluralismo cultural y autonomias étnicas en América Latina. In: BARTOLOMÉ, Miguel A.; BARABAS, Alícia M. (Coord.). Autonomias étnicas y Estados nacionais. México: Instituto Nacional de Antropologia e História, 1998.

BELLAMY, Alex J.; DAVIES, Sara E. ; GLANVILLE Luke (Ed.). The responsability to protect and international law. Boston: Martinus Nijhoff Publishers, 2011.

BITTAR, Eduardo C. B. Direitos Humanos no Século XXI: cenários de tensão. Rio de Janeiro: Forense Universitária; São Paulo: ANDHEP; Brasília, DF: Secretaria Especial dos Direitos Humanos, 2009.

BIERRENBACH, Ana Maria. O conceito de responsabilidade de proteger e o direito internacional humanitário. Brasília, DF: Fundação Alexandre de Gusmão, 2011.

BOBBIO, Norberto. A era dos direitos. Tradução de Carlos Nelson Coutinho. Apresentação Celso Lafer. Rio de Janeiro: Elsevier, 2004.

Paidós, 1993.

Igualdade y libertad. Introducción de Gregorio Peces-Barba. Barcelona: 
BOURANTONIS, Dimitris; WIENER, Jarrod. The United Nations in the new world order. the world organization at fifty. Londres: Macmillan Press, 1995.

BOUTROS-GHALI, B. Consolidación de la paz y el desarrollo: memoria anual sobre la labor de la Organización entre los períodos de sesiones cuadragésimo octavo y cuadragésimo noveno. Nova lorque: Departamento de Informações Públicas, 1994. p. 193 -197.

BROWNLIE, I. Principles of public international law. 5. ed. Oxford: Oxford University Press, 1998.

BUCHANAN, Allen. Justice, legitimacy and self-determination: moral foundations for international law. Oxford: Oxford University Press, 2007. p. 351-353.

CACHAPUZ DE MEDEIROS, Antônio Paulo. O poder de celebrar tratados. Porto Alegre: Fabris, 1995.

Desafios do Direito Internacional Contemporâneo. Rio de Janeiro: Fundação Alexandre de Gusmão, 2007.

CANOTILHO, J. J. Gomes. Direito constitucional e teoria da Constituição. Coimbra: Almedina, 1999.

CAPOTORTI, Francesco. The Protection of Minorities under Multilateral Agreements on Human Rights in The Italian Yearbook of International Law. 1976.

CASTRO, Thales. Conselho de Segurança da ONU: Unipolaridade, Consensos e Tendências. Curitiba: Juruá, 2007.

CHARTERS, Claire; STAVENHAGEN, Rodolfo. El desafio de la Declaración - História y futuro de la declaración de la ONU sobre pueblos indígenas. Copenhage; Dinamarca: IWGIA, 2010.

CLARK, Howard. Civil resistance in Kosovo. London: Pluto Press, 2000. Disponível em:<balkanwitness.glypx.com/civil-resistance-in-kosovo.pdf>. Acesso em: 8 dez. 2016.

COLAÇO, Thais Luzia. "Incapacidade" indígena: tutela religiosa e violação do direito guarani nas missões jesuíticas. Curitiba: Juruá, 2000. p. 9.

CUNHA, Manuela Carneiro da. Os direitos do índio: ensaios e documentos. São Paulo: Brasiliense, 1987.

D'ADESKY, Jacques. Pluralismo étnico e multiculturalismo: racismos e anti-racismos no Brasil. Rio de Janeiro: Pallas, 2001.

DOBROWOLSKI, Samantha Chantal. A construção social do sentido da Constituição na democracia contemporânea: entre a soberania popular e direitos humanos. Rio de Janeiro: Lumen Juris, 2007.

A justificação do direito e a sua adequação social. Porto Alegre: Livraria do Advogado, 2002. 
EAGLETON, Terry. A ideia de cultura. Tradução Sandra Castello Branco. 2. ed. São Paulo: Unesp, 2011. p.10.

FALCÓN Y TELLA, María José. Equidad, derecho y justicia. Madrid: Universitaria Ramón Areces, 2005. p. 267-270.

FARIÑAS DULCE, Maria José. Globalización, ciudadanía y derechos humanos, Dikynson. Cuadernos Bartolomé de las Casas, Madrid, n. 16, 2000.

FERRAJOLI, Luigi. La democracia através de los derechos: el constitucionalismo garantista como modelo teórico y como proyecto político. Madrid: Trotta, 2014.

. Derechos y garantias: la ley del más débil. Madrid: Trotta, 2004.

FERREIRA FILHO, Manoel Gonçalves. Estado de direito e constituição. São Paulo: Saraiva, 2012.

FITZGERALD, Valpy et al (Ed.). Globalization, violent conflict and self-determination. Hampshire: Palgrave; MacMillan, 2006.

GARCIA, David Bondia; MUÑOZ, Manuel Ramiro (Coord.). Víctimas invisibles, conflito armado y resistencia civil en Colombia. Barcelona: Huygens Editorial, 2009.

GARCIA, Fernando; JIMÉNEZ, Inmaculada (Coord.). Informe sobre el conflicto y la guerra do Kosovo. Madrid: Ediciones del Oriente y del Mediterráneo, 1999.

GARRIDO GOMEZ, Maria Isabel. La igualdad en el contenido y en la aplicación de la ley. 1. ed. Madrid: Dykinson, 2009.

GUIMÓN, Julen. El derecho de autodeterminación: el território y sus habitantes. Bilbao: Universidad de Deusto. 1995. p. 35-53. (Série Derecho).

HABERMAS, J. Pensamento pós-metafísico: estudos filosóficos. Rio de Janeiro: Tempo Brasileiro, 1990.

HELLER, Ágnes. Más allá de la justicia. Barcelona: Crítica, 1999.

HOFFE, Otfried. Justiça política. Tradução de Peter Naumann. Porto Alegre: Martins Fontes, 2001. p. 170-171.

HONNETH, Axel. Luta por reconhecimento: a gramática moral dos conflitos sociais. Tradução de Luiz Repa. São Paulo: Editora 34, 2003.

INFORME anual da Assembleia Geral das Nações Unidas de 20 de setembro de 1999. Disponível em:<http://www.un.org/press/en/1999/19990920.sgsm7136.html>. Acesso em: 8 nov. 2016.

JACQUES, Paulino. Da igualdade perante a lei: fundamento, conceito e conteúdo. 2. ed. Rio de Janeiro: Revista Forense, 1957.

KALDOR, Mary. New and old wars: organized violence in a global era. 2. ed. California: Stanford University Press, 2007. 
KELSEN, Hans. Teoria pura do direito. Tradução de Baptista Machado. São Paulo: Martins Fontes,1999.

KYMLICKA, Will. Ciudadanía multicultural. Barcelona: Paidós, 1996.

LAFER, Celso. A internacionalização dos direitos humanos: constituição, racismo e relações internacionais. Barueri: Manole, 2005.

MALHEIROS, Antônio Carlos; BACARIÇA, Josephina; VALIM, Rafael (Coord.). Direitos humanos: desafios e perspectivas. Belo Horizonte: Fórum, 2011. (Coleção Fórum Direitos Humanos, 3).

MARITAIN, Jacques. Los derechos del hombre y la ley natural: Cristianismo y democracia. Madrid: Palabra, 2001.

MARTÍNEZ COBO, José R. Study of the problem of discrimination against indigenous populations. In: PROPOSALS and Recommendations, prepared by Mr. José R. Martínez Cobo. New York: United Nations, 1983. United Nations. Permanent Forum on Indigenous Issues. v.5. Conclusiones. Disponível em: <http://undesa dspd.org.dnnmax.com/IndigenousPeoples/LibraryDocuments/Mart\%C3\%ADnezCob oStudy.aspx>. Acesso em: 13 dez. 2016.

MAZZUOLI, Valério de Oliveira. Curso de Direito Internacional. 8. ed. rev. atual. e ampl. São Paulo: Editora Revista dos Tribunais, 2014. p.132-133.

MELLO, Celso Antônio Bandeira de. O conteúdo jurídico do princípio da igualdade. 3. ed. São Paulo: Malheiros, 2000.

- Princípio da isonomia: desequiparações proibidas e desequiparações permitidas. Revista Trimestral de Direito Público, n. 1, 1993. p. 82.

MIRANDA, Jorge. Manual de direito constitucional: direitos fundamentais. 9. ed. Coimbra: 49, 2012.

MORAES, Alexandre de. Direitos humanos fundamentais. São Paulo: Atlas, 1998. (Coleção Temas Jurídicos, 3).

MUSGRAVE, Thomas D. Self-determination and national minorities. Oxford: Oxford University Press, 2000. (Oxford Monographs in International Law).

NOGUEIRA, Arthur H. V. Kosovo: país ou província? Brasília: Fundação Alexandre de Gusmão (Funag), 2015. Disponível em: <http://funag.gov.br/loja/download/1138KOSSOVO_Provincia\%20ou\%20Pais.pdf>. Acesso em: 20 nov. 2016.

OBIETA CHALBAUD, J. A. El derecho de autodeterminación de los pueblos: un estudio interdisciplinar de derechos humanos. Bilbao: Universidade de Deusto, 1984.

OLIVEIRA, Marcelo Andrade Cattoni de. Processo constitucional. Belo Horizonte: Pergamum, 2013.

OLIVEIRA, Roberto Cardoso de. Identidade, Etnia e Estrutura Social. São Paulo: Livraria Pioneira, 1976. p. 3. 
OLLÉ, Manuel. Justicia universal para crímenes internacionales. Madrid: La Ley, 2008. PÉREZ LUÑO, Antonio Enrique. Dimensiones de la igualdad. 2. ed. Madrid: Dykinson, 2007.

PIOVESAN, Flávia. Direitos humanos e direito constitucional internacional. São Paulo: Max Limonad, 1997.

PRZETACZNIK, F. The basic collective human right to self-determination of peoples and nations as a prerequisite for peace. Law School Journal of Human Rights, New York, Part One, v. 3, 1990. p. 49-109.

RAWLS, John. Justiça como equidade: uma reformulação. São Paulo: Martins Fontes, 2003.

REALE, Miguel. Teoria do Estado e do direito. 5. ed. São Paulo: Saraiva, 2003. p. 127.

REDIN, Giuliana. Direito à autodeterminação dos povos e desenvolvimento: Uma análise a partir das relações internacionais. Passo Fundo: Méritos, 2006.

RIBEIRO, Darcy. O processo civilizatório: etapas da evolução sociocultural. 10. ed. Petrópolis, RJ: Vozes, 1987.

RIGO SUREDA, A. The evolution of the right of self-determination: a study of United Nations Practice. Leiden: Sijthoff, 1973.

ROSENFELD, Michel. A identidade do sujeito constitucional. Tradução de Menelik de Carvalho Netto. Belo Horizonte: Mandamentos, 2003.

ROTHENBURG, Walter Claudius, Igualdade. In: LEITE, George Salomão; SARLET, Ingo Wolfgang (Coord.). Direitos fundamentais e estado constitucional: estudos em homenagem a J. J. Gomes Canotilho. São Paulo: Revista dos Tribunais. Coimbra, 2009. p. 359-364.

RUILOBA SANTANA, E. Una nueva categoría en el panorama de la subjetividad internacional: el concepto de pueblo: estudos de Direito Internacional. Madrid: Tecnos, 1979. v. 1 (Homenagem ao Professor Miaja de la Muela).

SABADELL, Ana Lúcia. Manual de Sociologia Jurídica: introdução a uma leitura externa do Direito. São Paulo: Revista dos Tribunais, 2000.

SALIBA, Aziz Tuffi. Conselho de Segurança da ONU: sanções e limites jurídicos. Curitiba: Juruá, 2009.

SANTILLI, Juliana. Os direitos indígenas e a constituição. Porto Alegre: Sergio Antonio Fabris, 1993.

SARLET, Ingo Wolfgang. A eficácia dos direitos fundamentais. Porto Alegre: Livraria do Advogado, 2001.

SEMPRINI, Andréa. Multiculturalismo. Bauru: EDUSC, 1999. 
SHAW, Malcolm Nathan. International law. 6. ed. Cambridge: Cambridge University Press, 2008.

SILVA, José Afonso da. Terras tradicionalmente ocupadas pelos índios: os direitos indígenas e a Constituição. Porto Alegre: Fabris, 1993.

. Curso de direito constitucional positivo. São Paulo: Malheiros, 2005.

SILVA, Orlando Sampaio; GALVÃO, Eduardo (Coord.). Índios e Caboclos. São Paulo: Annablume, 2007.

SILVA, Roberto Luiz. Direito internacional público. 2. ed. rev. atual. e ampl. Belo Horizonte: Del Rey, 2002.

SOUZA, Jessé. A construção social da subcidadania: para uma sociologia política da modernidade periférica. Belo Horizonte: UFMG, 2003.

SOUZA FILHO, Carlos Frederico Marés de. O renascer dos povos indígenas para o direito. Curitiba: Juruá, 2009.

TAYLOR, Charles. As fontes do self: a construção da identidade moderna. São Paulo: Loyola, 2013.

- A política de reconhecimento. Multiculturalismo: examinando a política de reconhecimento. Lisboa: Piaget, 1998.

. El multiculturalismo y "la política del reconocimiento". Trad. de Mónica Utrilla de Neira. México: Fondo de Cultura Económica, 2001.

THORNBERRY, P. The democratic or internal aspect of self-determination with some remarks on federalism. Dordrecht, London: M. Nijhoff Publishers,1993. p.101.

TOMUSCHAT, C. Modern law of self-determination. Boston: Dordrecht; London: Martinus Nijhoff, 1993.

TORRES, Ricardo Lobo. A cidadania multidimensional da era dos direitos: teoria dos direitos fundamentais. Rio de Janeiro: Renovar, 1999.

TRINDADE, Antônio Augusto Cançado. A humanização do direito internacional. Belo Horizonte: Del Rey, 2006.

. Os Tribunais Internacionais e a realização da Justiça. 2. ed. ampl. Belo Horizonte: Del Rey, 2017.

- El ejercicio de la función judicial internacional: memorias de la Corte Interamericana de Derechos Humanos. 3. ed. Belo Horizonte: Del Rey, 2016.

UMOZURIKE, U. O. Self-determination in international law. Hamden, Connecticut: Archon Books, 1972. 
VILLALPANDO, Waldo. Los derechos humanos: la conciencia moral del siglo XX. In: . De los derechos humanos al derecho internacional penal. Buenos Aires: Abeledo-Perrot, 2000. VILLARES, Luiz Fernando. Direito e povos indígenas. Curitiba: Juruá, 2009.

WALZER, Michael. Esferas da justiça: uma defesa do pluralismo e da igualdade. São Paulo: Martins Fontes, 2003.

WOLKMER, Antonio Carlos. Pluralismo jurídico: fundamentos de uma nova cultura no direito. São Paulo: Ômega, 1994.

. Direito e justiça na América Indígena: da conquista à colonização. Porto Alegre: Livraria do Advogado, 1998.

WUCHER, Gabi. Minorias: proteção internacional em prol da democracia. São Paulo: Juarez de Oliveira, 2000.

\section{2) LEGISLAÇÃO}

ALVARÁ de 4 de abril de 1755. Disponível em: < http://www.nacaomestica.org/alvara_regio_04_abril_1755_cabouclos.htm>. Acesso em: 30 abr. 2017.

BRASIL. Câmara dos Deputados. Projeto de Lei n. 2.057/1991. Dispõe sobre o Estatuto das Sociedades Indígenas. Disponível em: < http://www.camara.gov.br/proposicoesWeb/fichadetramitacao?idProposicao=17569> . Acesso em: 30 abr. 2017.

. Constituição (1934). Constituição da República dos Estados Unidos do Brasil, 1934. Disponível em: <http://www2.camara.leg.br/legin/fed/consti/19301939/constituicao-1934-16-julho-1934-365196-publicacaooriginal-1-pl.html>. Acesso em: 30 abr. 2017.

. Constituição (1937). Constituição dos Estados Unidos do Brasil, 1937. Disponível em: <http://www2.camara.leg.br/legin/fed/consti/1930-1939/constituicao35093-10-novembro-1937-532849-publicacaooriginal-15246-pl.html>. Acesso em: 30 abr. 2017.

Disponível

Constituição (1946). Constituição dos Estados Unidos do Brasil, 1946. http //www pla abr. 2017.

Disponível

Constituição (1967). Constituição da República Federativa do Brasil, 1967. http://www.planalto.gov.br/ccivil_03/Constituicao/Constituica067.htm>. Acesso em: 30 abr. 2017. 
. Constituição (1969) Emenda constitucional n. 1, de 17 de outubro de 1969. Edita o novo texto da Constituição Federal de 24 de janeiro de 1967. Diário Oficial da União, Brasília, 20 out. 1969. Disponível em: < http://www.planalto.gov.br/ccivil_03/Constituicao/Emendas/Emc_anterior1988/emc01 -69.htm>. Acesso em: 15 abr. 2017.

. Constituição (1988) .Constituição da República Federativa do Brasil de 5 de outubro de 1988. Brasília, DF: Senado Federal. Disponível em: < https://www.planalto.gov.br/ccivil_03/Constituicao/Constituicao.htm>. Acesso: 30 abr. 2017

Decreto n. 5.051 de 19 de abril de 2004. Promulga a Convenção n. 169 da Organização Internacional do Trabalho - OIT sobre Povos Indígenas e Tribais. Diário Oficial da União. Brasília, 20 abr. 2004. Disponível em: < http://www.planalto.gov.br/ccivil_03/_Ato2004-2006/2004/Decreto/D5051.htm>.

Acesso em: 30 abr. 2017.

. Lei n. 6.001, de 17 de dezembro de 1973. Dispõe sobre o Estatuto do Índio. In: LEGISLAÇÃO indigenista. Brasília, DF: Senado Federal: Subsecretaria de Edições Técnicas, 1993. p. 71.

. Presidência da República. Lei n. 3.071, de 1ํ de janeiro de 1916. Código civil de 1916. Diário Oficial da União, 5 jan. 1916. Disponível em: <http://www.camara.gov.br/sileg/integras/111025.pdf>. Acesso em: 20 set. 2016.

. Presidência da República. Lei n. 5.371, de 5 de dezembro de 1967. Autoriza a instituição da "Fundação Nacional do Índio" e dá outras providências. Diário Oficial da União, Brasília, 6 dez. 1967. Disponível em: <http://www.planalto. gov.br/ccivil_03/leis/1950-1969/L5371.htm>. Acesso em: 30 abr. 2017.

CONVENÇÃO sobre direitos e deveres dos Estados. 1993. Disponível em: <http://honoriscausa.weebly.com/uploads/1/7/4/2/17427811/convencao_sobre_direit os_e_deveres_dos_estados-12.pdf>. Acesso em: 12 nov. 2016.

DECLARAÇÃO Universal dos direitos dos povos de 1976. Disponível em: <http://www.dhnet.org.br/direitos/sip/textos/direitos_povos.html>. Acesso em: 9 dez. 2016.

DECRETO N. 5.051, de 19 de abril de 2004. Promulga a Convenção no 169 da Organização Internacional do Trabalho - OIT sobre Povos Indígenas e Tribais. Disponível em: <http://www.planalto.gov.br/ccivil_03/_ato20042006/2004/decreto/d5051.htm>. Acesso em: 09 maio 2017.

DECRETO N. 6.177, de $1^{\circ}$ de agosto de 2007. Promulga a Convenção sobre a Proteção e Promoção da Diversidade das Expressões Culturais, assinada em Paris, em 20 de outubro de 2005 . Disponível em: < http://www.planalto.gov.br/ccivil_03/_Ato2007-2010/2007/Decreto/D6177.htm> Acesso em: 09 maio 2017. 
FRANÇA. Assembleia Nacional Constituinte. Declaração dos Direitos do Homem e do Cidadão, 1979. Disponível em: <http://pfdc.pgr.mpf.mp.br/atuacao-e-conteudos-deapoio/legislacao/direitos-humanos/declar_dir_homem_cidadao.pdf>. Acesso em: 31 jan. 2017.

LÊNIN, Vladimir. Bill on the equality of nations and the safeguarding of the rights of national minorities (Projeto de lei sobre a igualdade das nações e a salvaguarda dos direitos das minorias nacionais). 1914. Disponível em: < https://www.marxists.org/archive/lenin/works/1914/may/00.htm>. Acesso em: 15 dez. 2016.

ORGANIZAÇÃO DAS NAÇÕES UNIDAS (ONU). Assembleia Geral. Carta das Nações Unidas. Adotada e aberta à assinatura pela Conferência de São Francisco em 26 de junho de 1945. Disponível em: <https://nacoesunidas.org/carta/>. Acesso em: 31 jan. 2017.

Assembleia Geral. Declaração das Nações Unidas sobre os Direitos dos Povos Indígenas, de 13 de setembro de 2007. Rio de Janeiro: Centro de Informação das Nações Unidas (United Nations Information Centre), 2008. Disponível em: <http://www.un.org/esa/socdev/unpfii/documents/DRIPS_pt.pdf>. Acesso em: 31 jan. 2017.

Assembleia Geral. Declaração sobre a independência colonial de 14 de dezembro de 1960. Disponível em: < http://www.dhnet.org.br/direitos/sip/onu/spovos/dec60.htm>. Acesso em: 31 jan. 2017.

Assembleia Geral. Pacto Internacional de Direitos Civis e Políticos. 1976. Disponível em: <http://www.refugiados.net/cid_virtual_bkup/asilo2/2pidcp.html>. Acesso em: 31 jan. 2017.

. Comissão Africana dos Direitos Humanos e dos Povos. Carta Africana de

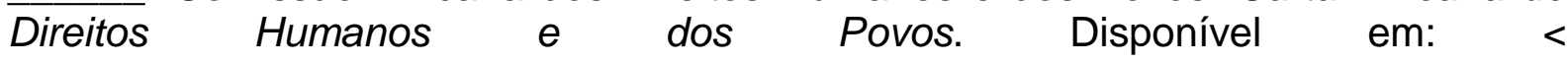
http://www.achpr.org/pt/instruments/achpr/>. Acesso em: 31 jan. 2017.

Relatório do Alto Comissariado de Direitos Humanos da ONU, 2017. Disponível em: <http://acnudh.org/pt-br/home-2/> Acesso em: 15 maio 2017.

ORGANIZAÇÃO DAS NAÇÕES UNIDAS PARA A EDUCAÇÃO, A CIÊNCIA E A CULTURA (UNESCO). Assembleia Geral. Declaração Universal dos Direitos Humanos. $\quad 1948 . \quad$ Disponível em: < http://unesdoc.unesco.org/images/0013/001394/139423por.pdf>. Acesso em: 31 jan. 2017. 


\section{3) PARECERES E OPINIÕES CONSULTIVAS}

CORTE INTERNACIONAL DE JUSTIÇA (CIJ). Opinião Consultiva de 22 de julho de 2010. Ilustra a conformidade do Direito Internacional na Declaração Unilateral de Independência no Kosovo por suas instituições provisórias do autogoverno. Disponível em: <http://www.mfa-ks.net/?page=2,1>. Acesso em: 11 nov. 2016.

. Caso Sahara Ocidental. Disponível em: <http://www.icj-cij.org/docket/index. $\overline{\mathrm{php} ? \mathrm{p} 1}=3 \& \mathrm{p} 2=4 \&$ code $=$ sa $\&$ case $=61 \& \mathrm{k}=69>$. Acesso em: 9 dez 2016 .

KOSOVO. Ministério dos Negócios Estrangeiros do. Opinião consultiva da declaração unilateral no Kosovo. Disponível em: <http://www.mfa-ks.net/?page=2,1>. Acesso em: 11 abr. 2017.

ORGANIZAÇÃO DAS NAÇÕES UNIDAS (ONU). Assembleia Geral. La opinión Consultiva de la Corte Internacional de Justicia de 22 de julio de 2010 sobre la conformidad con el Derecho internacional de la declaración unilateral de independencia de Kosovo. Revista Española de Derecho Internacional v. 43, n. 1, p. 149-197, 2011. Disponível em: < http://www.realinstitutoelcano.org/wps/wcm/connect/a6e5028044a3265585a587f55c b546a4/DT35-

2010_Gutierrez_Bermejo_Corte_Internacional_Justicia_Kosovo.pdf?MOD=AJPERE S\&CACHEID=a6e5028044a3265585a587f55cb546a4>. Acesso em: 14 maio 2017.

. Corte Internacional de Justiça (CIJ). Parecer consultivo da Assembleia Geral das Nações Unidas sobre as questões relativas ao Sahara Ocidental de 1974-1975. Disponível em: <http://www.icj-

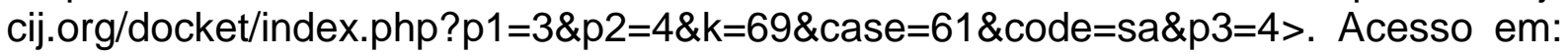
14 maio 2017.

PARECER Consultivo de 16 de outubro de 1975. Território do Sahara Ocidental. Opinião Consultiva. Disponível em: <http://centrodireitointernacional.com.br/wpcontent/uploads/2014/05/pareceres-consultivos_1974.pdf>. Acesso em: 14 maio 2017.

\section{4) ARTIGOS COMPLEMENTARES}

ALVES, José Augusto Lindgren. The Viena conference on human. Lua Nova [online], n. 32, p. 170-180, 1994. Disponível em: <http://dx.doi.org/10.1590/S0102-64451994 000100009 >. Acesso em: 13 nov. 2016.

BOUTROS-GHALI, B. Empowering the United Nations. Foreign Affairs, v. 89, 1992. Disponível em: <https://www.foreignaffairs.com/articles/1992-12-01/empoweringunited-nations>. Acesso em: 23 nov. 2016.

CAMPOS, Francisco. Igualdade de todos perante a lei. Revista Direito Administrativo, n. 10,2013 . p. $397-409$. 
CANCLINI GARCIA, Néstor. A integração num contexto pluriétnico e pluricultural. Revista Tempo Brasileiro. Rio de Janeiro, n. 122,1995. p. 44.

CENTER FOR SECURITY POLICY. Clinton should back Bosnia in rejecting VanceOwen plan. 1993. Disponível em: <http://www.centerforsecuritypolicy .org/1993/02/ 04/thanks-but-no-thanks-clinton-should-back-bosnia-in-rejecting-vance-owen-peacein-our-time-2//>. Acesso em: 8 nov. 2016.

COMPARATO, Fabio Konder. Igualdade, desigualdade. Revista Trimestral de Direito Público, n. 1, 1993. p. 69.

EAGLETON, C. Self-determination in the United Nations. American Journal international Law, v. 77, 1953, p. 88-93.

YOUNG, Iris Marion. Representação política, identidade e minorias, Lua Nova, São Paulo, p.142, 2006. Disponível em: <http://www.scielo.br /pdf/ln/n67/a06n67.pdf>. Acesso em: 2 mai. 2017.

LÊNIN, Vladimir. The rights of nations to self-determination. Journal Prosveshcheniye, n. 4-6 abr./jun. 1914. Disponível em: <https://www.mar xists.org/archive/lenin/works/1914/self-det/>. Acesso em: 31 jan. 2017.

LÉON-PORTILLA, Miguel. América Latina: múltiplas culturas, pluralidade de línguas. Revista Tempo Brasileiro: América Latina: vias e desvios, Rio de Janeiro, n. 2, 1995. p. $112-123$.

MANCINI, Pasquale Stanislao. La teoria italiana del colonialismo. Revista del Derechos Internacionales, LXXVIII, 1985. p. 677-705.

MARTíN, Araceli Mangas. Humanización, democracia y estado de derecho en el ordenamiento internacional. Madrid: Real Academia de Ciencias Morales y Políticas, 2014. Disponível em: <http://www.racmyp.es/R/racmyp/docs/discursos/D88.pdf>. Acesso em: 21 nov. 2016.

MARTÍNEZ COBO, José R. Estudio del problema de la discriminación contra las poblaciones indígenas. Doc./CN.4/Sub.2/1986/7/Add. 4, v.5, p. 17, § 198, p. 40-41. 1987. Disponível em: <http://www.derechos.org/nizkor/bolivia/doc/coboes.html>. Acesso em: 9 dez. 2016.

ORGANIZATION FOR SECURITY AND CO-OPERATION IN EUROPE. Human rights in Kosovo: as seen, as told. 14 jun./31out. 1999. v. 2. p. xvii. Disponível em: <http://www.osce.org/kosovo/17781?download=true>. Acesso em: 8 nov. 2016.

THE RESPONSIBILITY to protect. Disponível em: <http://responsibilitytoprotect. org/ICISS\%20Report.pdf>. 2001. Acesso em: 10 nov. 2016.

URBINA, Jorge Julio. Las Naciones Unidas y su contribución al desarrollo del principio de autodeterminación. Dereito: revista jurídica da Universidade de Santiago de Compostela, Santiago de Compostela v. 10, n. 1, p. 197-239, 2001. Disponível em: <https://minerva.usc.es/xmlui/handle/ 10347/7737>. Acesso em: 13 nov. 2016. 
ZYBERI, Gentian. Self-Determination through the Lens of the International Court of Justice. Netherlands International Law Review, v. 56, p. 431- 453, 2009. Disponível em: <http://dx.doi.org/10.1017/S0165070X0900429X>. Acesso em: 14 maio 2017.

\section{5) RESOLUÇÕES DA ORGANIZAÇÃO DAS NAÇÕES UNIDAS (ONU)}

ORGANIZAÇÃO DAS NAÇÕES UNIDAS (ONU). Asamblea General del Consejo de Seguridad. Agenda for peace: report of the Secretary-General Pursuant to the Statement Adopted by the Summit Meeting of the Security Council, 31 January 1992, A/47/227-S/24111, 17 June 1992. Disponível em: < www.un.org/es/comun/docs/?symbol=A/47/277>. Acesso em: 21 nov. 2016.

Assembleia Geral. Resolução n.1.514 (XV), de 14 de dezembro de 1960. Declaração sobre a Concessão da Independência aos Países e Povos Coloniais. Disponível em: <http://www.dhnet.org.br/direitos/sip/onu/spovos/dec60.htm>. Acesso em: 13 dez. 2016.

Assembleia Geral. Resolução n.1.541 (XV), de 15 de dezembro de 1960. Disponível em: <http://www.un.org/documents/ga/res/15/ares15.htm> Acesso em: 13 maio 2017.

Assembleia Geral. Resolução n. 47/135, de 18 de dezembro de 1992. Declaração dos Direitos das Pessoas pertencentes a Minorias Nacionais, Étnicas, Religiosas e Linguísticas. Disponível em: < http://direitoshumanos.gddc.pt/3_2/IIIPAG3_2_10.htm>. Acesso em: 15 dez. 2016.

Assembleia Geral. Resolução n. 2.625 (XXV), de 24 de outubro de 1970. Declaração sobre os Princípios de Direito Internacional referente às relações de Amizade e Cooperação entre os Estados de acordo com a Carta das Nações Unidas. Disponível em: <http://www.un.org/documents/ga/res/25/ares25.htm>. Acesso em: 22 abr. 2017.

Assembléia Geral. 34 Sessão. ONU. Resolução 34/91 de 12 de dezembro de 1979. Questão das Ilhas Gloriosas, Juan de Nova, Europa. Disponível em: $<$ http://www.un.org/es/comun/docs/?symbol=A/RES/34/91> Acesso em: 17 de maio de 2017.

. Assembleia Geral. Resolução 61/295, 13 de setembro de 2007. Disponível em: $<$ https://documents-ddsny.un.org/doc/UNDOC/GEN/N06/512/10/PDF/N0651210.pdf?OpenElement>. Acesso em: 9 dez. 2016.

. Assembleia Geral. Resoluções. Nova York, 8 de outubro de 2008. Disponível em: <http://www.un.org/es/ga/63/ resolutions.shtml>. Acesso em: 8 dez. 2016.

. Conselho de Segurança. Resolução n. 770, de 13 de agosto de 1992. Disponível em: <http://www.un.org/en/sc/documents/resolutions/1992.shtml>. Acesso em: 21 nov. 2016. 
. Conselho de Segurança. Resolução n. 776, de 13 de agosto de 1992. Disponível em: <http://www.un.org/en/sc/documents/resolutions/1992.shtml>. Acesso em: 21 nov. 2016.

. Conselho de Segurança. Resolução n. 1.160, de 31 de março de 1998. Adaptada pelo Conselho de Segurança na sua $3.868^{a}$ sessão. Disponível em: <http://legismactext.safp.gov.mo/2000/S2/2000_29/AVCE13_ANP.htm>. Acesso em: 21 nov. 2016.

. Conselho de Segurança. Resolução n. 1.199 de 23 de setembro de 1998. Disponível em: <http://www.un.org/en/sc/documents/resolutions/1998.shtml>. Acesso em: 21 nov. 2016.

. Conselho de Segurança. Resolução n. 1.244, de 10 de junho de 1999. Disponível em:

$<$ https://documents-ddsny.un.org/doc/UNDOC/GEN/N99/172/89/PDF/N9917289.pdf?OpenElement>. Acesso em: 21 abr. 2017.

\section{6) RESOLUÇÕES DA FUNDAÇÃO NACIONAL DO ÍNDIO (FUNAI)}

BRASIL. Conselho Nacional de Política Indigenista. Dispõe sobre a tese do Marco Temporal e o direito originário dos povos indígenas às suas terras tradicionais. Disponível em: <http://www.funai.gov.br/arquivos/conteudo/presidencia/CNPI_Conselho/Atos_e_Nor mas/RESOLUCOES/CNPI_2016_Resol004.pdf>. Acesso em: 11 abr. 2017.

- Ministério da Justiça. Conselho Nacional de Política Indigenista. Pela demarcação de todas as terras indígenas do Brasil. Disponível em: <http://www.funai.gov.br/arquivos/conteudo/presidencia/CNPI_Conselho/Atos_e_Nor mas/RESOLUCOES/CNPI_2016_Resol003.pdf>. Acesso em: 11 abr. 2017.

. Ministério da Justiça. Conselho Nacional de Política Indigenista. Resolução $n$. 5. Dispõe sobre o direito dos povos indígenas de se fazerem representar em processos judiciais. Disponível em: <http://www.funai.gov.br/ arqui vos/conteudo/presidencia/CNPI_Conselho/Atos_e_Normas/RESOLUCOES/CNPI_2 016_Resol005.pdf>. Acesso em: 11 abr. 2017.

\section{7) DEMAIS FONTES DE PESQUISAS}

ANGOSTO, Ricardo. Las consecuencias humanitarias del conflicto do KosovoMetohija: documentos de segurança do Ministério da Defesa. Madrid, 2006. Disponível em: <http://www.defensa.gob.es/ceseden/Galerias/destacados/publicaciones/docSegyDe f/ficheros/002_FUTURO_DE_KOSOVOx_IMPLICACIONES_PARA_ESPANA.pdf $>$. Acesso em: $1 \overline{0}$ nov. $201 \overline{6}$. 
BANNON, Alicia L. The responsibility to protect: the UN world summit and the question of unilateralism. The Yale Law Journal, v. 115, n. 5, 2006. Disponível em: $<$ http://www.yalelawjournal.org/comment/the-responsibility-to-protect-the-un-worldsummit-and-the-question-of-unilateralism>. Acesso em: 10 nov. 2016.

COMISSÃO INTERNACIONAL SOBRE A INTERVENÇÃO E A SOBERANIA DOS ESTADOS (CIISE). The responsibility to protect. Disponível em: <www.responsibilitytoprotect.org/ICISS\%20Report.pdf>. Acesso em: 9 nov. 2016.

CONHEÇA o tratado de paz de 14 pontos proposto por Woodrow Wilson. Folha Online, 2008. Disponível em: <http://m.folha.uol.com.br/mundo/2008/11/466290conheca-o-tratado-de-paz-de-14-pontos-proposto-por-woodrow-wilson.shtml>. Acesso em: 30 jan. 2017.

CONSTITUCIÓN Política de Colombia. Disponível em: <http://www.corteconstitucional.gov.co/inicio/Constitucion\%20politica\%20de\%20Colo mbia\%20-\%202015.pdf>. Acesso em: 08 de maio de 2017.

CONSTITUCIÓN del Ecuador. Disponível em: <http://www.asambleanacional. gov.ec/documentos/constitucion_de_bolsillo.pdf>. Acesso em: 08 maio 2017.

CONSTITUCIÓN Política de los Estados Unidos Mexicanos. Disponível em: <http://www.diputados.gob.mx/LeyesBiblio/pdf/1_240217.pdf>. Acesso em: 08 maio 2017.

CORTE Interamericana del Derechos Humanos. Caso Comunidad Mayagna - Awas Tingni X Nicarágua. Sentença de 31 de agosto de 2001. Disponível em: <http://www.corteidh.or.cr/docs/casos/articulos/Seriec_79_esp.pdf> Acesso em: 09 maio 2017.

CORTE Interamericana del Derechos Humanos. Caso de las Hermanas Serrano Cruz Vs. El Salvador. Sentencia de 1 de marzo de 2005. Disponível em: <http://www. corteidh.or.cr/docs/casos/articulos/seriec_120_esp.pdf>. Acesso em: 16 maio 2017.

CORTE Interamericana del Derechos Humanos. Caso Comunidad Indígena Sawhoyamaxa Vs. Paraguay. Sentencia de 29 de marzo de 2006. Disponível em: <http://www.corteidh.or.cr/docs/casos/articulos/seriec_146_esp2.pdf>. Acesso em: 16 maio 2017.

DECLARAÇÃO e Programa de Ação de Viena. 1993. Disponível em: <https://www.oas.org/dil/port/1993\%20Declara\%C3\%A7\%C3\%A30\%20e\%20Progra ma\%20de\%20Ac\%C3\%A7\%C3\%A30\%20adoptado\%20pela\%20Confer\%C3\%AAnci a\%20Mundial\%20de\%20Viena\%20sobre\%20Direitos\%20Humanos\%20em\%20junho \%20de\%201993.pdf>. Acesso em: 31 mai. 2017.

DOCUMENTOS de seguridad y defensa. Ministerio de Defensa. Futuro de Kosovo: implicaciones para España. p. 68. Disponível em: <http://www.defensa.gob. es/ceseden/Galerias/destacados/publicaciones/docSegyDef/ficheros/002_FUTURO DE_KOSOVOx_IMPLICACIONES_PARA_ESPANA.pdf>. Acesso em: 16 maio $201 \overline{7}$. 
FABRE, Alain. Diccionario etnolingüístico y guía bibliográfica de los pueblos indígenas sudamericanos. Arawak. 2005. Disponível em: <http://www.ling.fi/Entradas \%20diccionario/Dic=Arawak.pdf >. Acesso em: 13 maio 2017.

FUERZA DE PROTECCIÓN DE LAS NACIONES UNIDAS (UNPROFOR). Disponível em: <http://www.un.org/es/peacekeeping/missions/past/unprofor/>. Acesso em: 21 nov. 2016.

GUTIÉRREZ ESPADA, Cesáreo. Uso de la fuerza, intervención humanitária y libre determinación (la "Guerra de Kosovo"). ANUARIO DE DERECHO INTERNACIONAL. Nueva York; Ginebra: Naciones Unidas, 2000. v. 16, p. 93-132.

HIGGINS, Rosalyn. Human rights in the International Court of Justice. Leiden journal of international law, v. 20, p. 747-751. 2007. Disponível em: <https://www.cambridge .org/core/journals/leiden-journal-of-international-law/article/human-rights-in-the-

international-court-of-justice/24A0AD2B3486F3D9709622C46A 3A9D7E\#>. Acesso em: 14 de maio de 2017.

JULGADO del Corte Constitucional de Colombia. Referência: Expediente T5.120.337, de 7 de fevereiro de 2017. Acción de tutela interpuesta por Martín Narváez Gómez en calidad de Capitán del resguardo indígena Carijona de Puerto Nare (Guaviare) y otro, contra la Presidencia de la República y otros. Disponível em: <http://www.corteconstitucional.gov.co/relatoria /2017/t-080-17.htm>. Acesso em: 15 maio 2017.

NACIONES UNIDAS. Los pueblos indígenas y el sistema de las Naciones Unidas. Folleto informativo n. 9, Rev.2, 2013. Disponível em: <http://www.ohchr.org/ Documents/Publications/GuidelPleaflet1sp.pdf>. Acesso em: 10 dez. 2016.

ORGANIZAÇÃO DAS NAÇÕES UNIDAS (ONU). Assembleia Geral. Ata final do cumprimento mundial em 2005. Disponível em: <http://www.ifrc.org/docs/idrl/ I520EN.pdf>. Acesso em: 9 nov. 2016.

PROGRAMA de ação da Declaração de Viena. Disponível em: < http://www.pge.sp.gov.br/centrodeestudos/bibliotecavirtual/instrumentos/viena.htm>. Acesso em: 14 abr. 2017.

REVISTA DA FACULDADE DE DIREITO DA UFMG. Fontes do Direito Internacional: Opinio Juris - É considerado um dos elementos constitutivos da norma internacional que assegura os costumes, pressupondo uma existência de regra jurídica autônoma, independente da regra que confere aos atos exteriores a qualidade de normas jurídicas. p. 22-34. Disponível em: <https://www.direito.ufmg.br/revista/index.php/ revista/article/viewFile/580/547>. Acesso em: 14 maio 2017.

ROCHA, Cármen Lúcia Antunes. Ação afirmativa: o conteúdo democrático do princípio da igualdade jurídica. Revista de Informação Legislativa, v. 33, n. 131, p. 283-295, jul./set. 1996. Disponível em: <http://www2.senado.leg.br/bdsf/item/id/176462>. Acesso: $1^{\circ}$ dez. 2016. 
STAVENHAGEN, Rodolfo. Etnodesenvolvimento: uma dimensão ignorada no pensamento desenvolvimentista. Anuário Antropológico, Rio de Janeiro: Tempo Brasileiro, n. 84, 1985.

UNITED NATIONS BIBLIOGRAPHIC INFORMATION SYSTEM. Disponível em: $<$ http://unbisnet.un.org/>. Acesso em: 31 mai. 2017. 
ANEXOS 
ANEXO A - Resolução 61/295 - Aprovada pela Assembleia Geral das Nações Unidas - ONU em 13 de setembro de 2007.

\section{DECLARACÃO DAS NACÕES UNIDAS SOBRE OS DIREITOS DOS POVOS INDÍGENAS}

Seragésimo primer periodo de sesiones

Tema 68 del programa

Resolución aprobada por la Asamblea General el 13 de septiembre de 2007

[sin remision provia a una Comision Principal (A/61/L.67 y Add.1)]

61/295. Declaración de las Naciones Unidas sobre los derechos

de los pueblos indigenas

La Asambiea General,

Tomando nota de la recomendación que figura en la resolución $1 / 2$ del Consejo de Derechos Humanos, de 29 de junio de $2006^{1}$, en la que el Consejo aprobó el texto de la Declaración de las Naciones Unidas sobre los derechos de los pueblos indigenas,

Recordando su resolución $61 / 178$, de 20 de diciembre de 2006 , en la que decidió aplazar el examen y la adopción de medidas sobre la Declaración a fin de disponer de más tiempo para seguir celebrando consultas al respecto, y decidió también concluir su examen de la Declaración antes de que terminase el sexagésimo primer periodo de sesiones,

Aprueba la Declaración de las Naciones Unidas sobre los derechos de los pueblos indigenas que figura en el anexo de la presente resolución.

$107^{\circ}$ sesion plenaria

13 de septiembre de 2007

Anero

Declaración de las Naciones Unidas sobre los derechos de los pueblos indigenas

La Asambiea General,

Guiada por los propósitos y principios de la Carta de las Naciones Unidas y la buena fe en el cumplimiento de las obligaciones contraidas por los Estados de conformidad con la Carta,

Affrmando que los pueblos indigenas son iguales a todos los demás pueblos y reconociendo al mismo tiempo el derecho de todos los pueblos a ser diferentes, a considerarse a sí mismos diferentes y a ser respetados como tales. 

ANEXO B - Resolução 1.514 (XV). Declaração sobre a Concessão da Independência
dos Países e Povos Coloniais da Assembleia Geral das Nações Unidas.

se admita a h Republice de Mali como Miembro de las Naciones Unidas ${ }^{31}$,

Habienda eraminado la solicitud de admisión presentada por la República de Mali*a

Decide admitir a la República de Malí como Miembro de las Naxiones Unidas.

876a. sesión plenaria, 28 de soptiembre de 1960.

1492 (XV). Admisión de la Federación de Ni. geria eomo Miembro de las Naciones Unidas

La Asamblea General,

Hobirsdo recibido la recomendación del Consejo de Seguridad de fecha 7 de octubre de 1960 , de que se admita a la Federnción de Nigeria como Miembro de las Naciones Unidas".

Hebirndo examinado la solicitud de admisión presentada por la Federación de Nigeria ${ }^{24}$.

Decids admitir a la Federsción de Nigeria camo Miembro de las Naciones Unidas.

893a. sesión plenoria, 7 de actubre de 1960 .

1495 (XV). Cooperación de los Estados Mienahros

La Asambiea General,

Profurdamente procoppada por el aumento de la tirantez internacional,

Considorando que el empeoramiento de las relaciones internacionales constituye in grave peligro para la paz y la cooperación mundiales,

Consciente de que tanto en la Asambles General camo en todo el mundo es necesario detener esta tendencia de las relaciones internacionales $y$ contribair a crear ura mayor armocia entre las nacianes independientemente de las diferencias que existan entre sus sistemas políticas y econúenicos,

1. Insta a todos las paises a que se abstengan, de conformidad con la Carta de las Naciones Unidas, de toda scción que pueda sgravar la tirantez internacional;

2. Repfrma la convicción de que la fuerza de las Naciones Unidas depende de la coopersción de sus Estados Miembros, que éstos deben prestarle sis restriceión alguna a fin de que la Organización se convierta en un instrumento más eficaz para salvaguardar la paz y promover el adelanto económico y social de todos los pueblos;

3. Insta asimismo a que se tomen inmediatamente medidas constructiras en relación con los problemas urgentes que conciernen a la paz del mundo y al adelanto de sus pueblos;

4. Exhorfe a todos los Estados Miembros a que hagan los mayores esfuerzos para alcanizar estos objetivos.

$907 a$, sesion plenaria, 17 de actubre de 1960 .

a thid, documento $\mathrm{A} / 4514$

as 7 bid, Soctmento $\mathrm{A} / 4512$

so $\mathrm{rbi2}$. secumento A/4533.
1503 (XV). Informe del Organiame Internacional de Energía Atómiea

La Asambiea General

Towa nota del informe del Organismo Internacional de Energia Atómica a la Asamblea General para el ลี่อ 1959-1960\%

943a. serión pienario. 12 de dicismbre de 1960 .

$1513(\mathrm{XV})$. Informe del Consejo de Seguridad

La Asambiea General

Toma nota del informe del Consejo de Seguridsd a ta Asamblea General, correspondiente al periodo comprendido entre el 16 de julio de 1959 y el 15 de julio de $1960^{\text {se }}$.

943a. sesión plenaria, 12 de diciembre de 1960.

1514 (XV). Declaración sohre la concesión de la independenein a los países y pueblos coloniales

La Asamblea General,

Teniondo prosmte que log pueblos del mundo ban proclamado en la Carta de las Naciones Unidas que están resueltos a reafirmar la fe en los derechos tundamentales del bombre, en la dignidad y el valor de la persona bumana, en la igualdaud de derechos de bombres $y$ majeres $y$ de las naciones grandes $y$ pequeîas $y$ a promover el progreso sccial $y$ a elevar el nivel de vida dentro de un concepto más amplio de la libertad,

Consciente de la necesidad de erear condicianes de estabilidad y bienestar y relaciones pacificas y amistosas basadas en el respeto de los principios de la igualdad de derechos y de la libre deterninación de todos los puchlos, y de asepurar el respeto universal de los derechos humanos $\mathrm{y}$ hs libertades fundamentales para todos sin hacer distinción por motivos de ram, sexo, fdioma o religión, $y$ la efectividad de tales derechos y libertades.

Reconocicndo el apasionado deseo de libertad que abrigan todos los pueblos dependientes y el papel decisivo de dichos pueblos en el logro de sta independencia,

Consciente de los crecientes conflictos que origina el hecho de negar la libertad a esos pueblos o de impedirla, fo cual constituye una grave amenaza s la paz mundial,

Considerendo el importante papel que corresponde s las Naciones Unidas como medio de favorecer el movimiento en pro de $\mathrm{h}$ independencia en los territorios en fideicomiso y en los territorios no sutónomas,

Reconociondo que los pueblos del mundo desean ardientemente of fin del colonialismo en todas sus manifestaciones.

Convescida de que la contiauación del colanialismo impide el desarrollo de la cooperación económica internacioaal, entorpece el desarrolo social, cultural y económico de las pueblas deperdientes y milita en contra del ideal de paz universal de las Naciones Unidas,

Afirmando que los paeblos pueden, para sus propios fines, disponer libremente de sus riquezas y recursos

is Intorne Anral de la Jarts de Golorwadores a la Conferen.

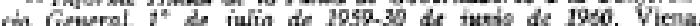
julio de 1960 (A/4531 y Corr.l y A/4531/AdA1)

as Docamentos Oficiales de as Assmble General, decimoquisio 
naturales sin perjuicio de las obhigaciones resultantes de la cooperación económica internacional, basada en el principio del provecho mutuo, y del derecho internacional,

Creyendo que el proceso de liberación es irresistible e irreversible y que, a fin de evitar crisis graves, es preciso poner fin al colonialismo $y$ a todas las prácticas de segregación y discriminación que lo acompafian,

Celebrando que en los últimos años muchos territorios dependientes hayan alcanzado la libertad y la independencia, y reconociendo las tendencias cada vez más poderosas hacia la libertad que se manifiestan en los territorios que no han obtenido atin la independencia,

Convencida de que todos los pueblos tienen un derecho inalienable a la libertad absoluta, al ejercicio de st soberania $y$ a la integridad de su territorio nacional,

Proclama solemnemente la necesidad de poner fin rápida e incondicionalmente al colonialismo en todas sus formas y manifestaciones;

$\mathrm{Y}$ a dicho efecto

Declara qุue:

1. La sujeción de pueblos a una subyugación, dominación y explotación extranjeras constituye una denegación de los derechos humanos fundamentales, es contraria a la Carta de las Naciones Unidas y compromete la causa de la paz y de la cooperación mundiales.

2. Todos los pueblos tienen el derecho de libre determinación; en virtud de este derecho, determinan libremente su condición politica y persiguen libremente su desarrollo economico, social y cultural.

3. La falta de preparación en el orden politico, económico, social o educativo no deberá servir nunca de pretexto para retrasar la independencia.

4. A fin de que los pueblos dependientes puedan ejercer pacífica y libremente su derecho a la independencia completa, deberá cesar toda acción armada o toda medida represiva de cualquier indole dirigida contra ellos, y deberá respetarse la integridad de su territorio nacional.

5. En los territorios en fideicomiso y no autónomos y en todos los demás territorios que no han logrado aún su independencia deberán tomarse inmediatamente medidas para traspasas todos los poderes a los pueblos de esos territorios, sin condiciones ni reservas, en conformidad con su voluntad y sus deseos libremente expresados, y sin distinción de raza, credo ni color, para permitirles gozar de una libertad y una ir.jependencia absolutas.

6. Todo intento encaminado a quebrantar total o parcialmente la unidad nacional y la integridad territorial de un pais es incompatible con los propósitos y principios de la Carta de las Naciones Unidas.

7. Todos los Estados deberán observar fiel y estrictamente las disposiciones de la Carta de las Naciones Unidas, de la Declaración Universal de Derechos Humanos y de la presente Declaración sobre la base de la igualdad, de la no intervención en los asuntos internos de los demás Estados y del respeto de los derechos soberanos de todos los pueblos $\mathrm{y}$ de su integridad territorial.

947a. sesión plenaria, 14 de diciembre de 1960.

\section{2 (XV). La situaeión en la Repúbliea del Congo}

La Asamblea General,

Habiendo examinado el tema titulado "La situación en la República del Congo",

Considerando que las resoluciones anteriores del Consejo de Seguridad y de la Asamblea General sobre esta cuestión siguen en vigor,

Docide mantener el tema en el programa de la continuación de sa decimoquinto periodo de sesiones.

958a. sernom plenaria, 20 de diciembre de 1960.

\section{Nota \\ Nombramiento de los miembros de la Comisión de Observaeión de la Paz (tema 18)}

En su 960a. sesión plenaria, celebrada el 20 de diciembre de 1960, la Asamblea General decidió volver a nombrar, para los af̂̉os civiles 1961 y 1962, a los actuales miembros de la Comisión de Observación de la Paz. La Comisión se compone, en consecuencia, de los Estados Miembros siguientes: Chrcoestovaguia, China, Estados Unidos de Amíkica, Francta, Honduras, India, Izak, Israel, Nueva Zetandta, Paktstín, Retwo Unido de Gran Bretaña e Irlanda det. Norte, Suecia, Unión de Repúblicas Socralistas Sovíticas y Uruguay.

Fonte: ORGANIZAÇÃO DAS NAÇÕES UNIDAS (ONU). Assembleia Geral. Resoluções aprovadas pela Assembleia Geral durante o 15ำ período de sessões. Resolução n.1.541 (XV), de 15 de dezembro de 1960. Disponível em: <http://www.un.org/es/documents/ag/res/15/ares15.htm> Acesso em: 13 maio 2017. 


\title{
ANEXO C - Opinião consultiva da declaração unilateral no Kosovo da Corte Internacional de Justiça - ClJ.
}

\section{OPINIÃO CONSULTIVA DA DECLARACÃO UNILATERAL NO KOSOVO}

\author{
COUR INTERNATIONALE DE JUSTICE INTERNATIONAL COURT OF JUSTICE
}

PALAIS DE LA PAIX 2517 KJ LA HAYE PAYS-BAS TÉLÉPHONE: +31 (0)70 3022323 TÉLEX: 32323 TÉLEGR:: INTERCOURT L.AHAYE

TÉLÉCOPIE: +31 (0)70 3649928

ADRESSE ELLECTR.: mailøicj-eij.org

SITE INTERNET: www.icj-eij.org

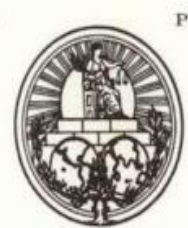

PEACE PALACE 2517 KJ THE HAGUE NETHERUANDS

TELEFAX: $+31(0) 703649928$

E-MAIL: mailøicj-eij.org

WEBSITE: www.icj-eij.org

Excellency,

I have the honour to refer to resolution 63/3 whereby the United Nations General Assembly requests the Court to give an advisory opinion on the question of the Accordance with International Law of the Unilateral Declaration of Independence by the Provisional Institutions of Self-Government of Kosovo. The text of the operative paragraph of this resolution, as received from the Secretary-General, reads as follows:

\section{"The General Assembly,}

Decides, in accordance with Article 96 of the Charter of the United Nations, to request the International Court of Justice, pursuant to Article 65 of the Statute of the Court, to render an advisory opinion on the following question:

'Is the unilateral declaration of independence by the Provisional Institutions of Self-Government of Kosovo in accordance with international law?"."

A copy of the request for advisory opinion in the bilingual printed version prepared by the Registry will be forwarded to you as soon as possible.

I further have the honour to acknowledge receipt of Your Excellency's letter dated 15 October 2008 and received in the Registry on the same day by facsimile, raising various issues with regard to the request for an advisory opinion.

The Court has decided, in accordance with Article 66, paragraph 2, of its Statute, that the United Nations and its Member States are likely to be able to furnish information on the question. It has fixed 17 April 2009 as the time-limit within which written statements on the question may be presented to the Court, and 17 July 2009 as the time-limit within which States and organizations having presented written statements may submit written comments on the other written statements. The subsequent procedure has been reserved for further decision. Please find herewith a copy of the Order made by the Court on 17 October 2008 to that effect.

His Excellency

Mr. Skender Hyseni

Str. "Ne̋në Tereza"

10000 Prishtina

Kosovo

Fonte: KOSOVO. Ministério dos Negócios Estrangeiros do. Opinião consultiva da declaração unilateral no Kosovo. Disponível em: <http://www.mfa-ks.net/?page=2,1>. Acesso em: 11 abr. 2017. 


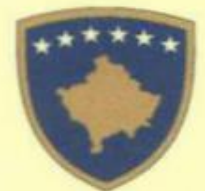 \\ Republika e Kosovës \\ Republika Kosova - Republic of Kosovo \\ Qeveria -Vlada - Govermment \\ Ministria e Punëve të Jashtme/Ministarstvo Inostranih Poslova \\ Ministry of Foreign Affairs}

15 October 2008

Sir,

I have the honour to refer to the request for an advisory opinion contained in General Assembly resolution 63/3, and to request that the Court invite the Republic of Kosovo to participate in the proceedings on a footing of equality with others, including the Republic of Serbia.

Resolution $63 / 3$ was proposed by Serbia, and was adopted by 77 votes in favour, 6 against, with 74 abstentions. In it, the General Assembly requested the Court to render an advisory opinion on the following question:

Is the unilateral declaration of independence by the Provisional Institutions of Self-Government of Kosovo in accordance with international law?

The question submitted to the Court is one in which Kosovo self-evidently has a profound and direct interest.

The importance of Kosovo being able to present its views to the Court, without prejudice to the Court's eventual response to the question contained in the request for an advisory opinion, was stressed by a considerable 
number of the representatives who spoke in the General Assembly debate on 8 October 2008, at which resolution $63 / 3$ was adopted, and was not opposed by any speaker (Press Release, General Assembly/10764; the verbatim record will appear in A/PV.63/22). Moreover, following its Declaration of Independence, the Republic of Kosovo has now been recognized by 51 States from around the world.

It is respectfully submitted that, if the Court is to consider the request submitted by the General Assembly, and at the same time remain true to its judicial character, it is important that Kosovo be invited to participate on a footing of complete equality with others, including Serbia, in the interests of the proper administration of justice. As the Court said in Eastern Carelia, '[t]he Court, being a Court of Justice, cannot, even in giving advisory opinions, depart from the essential rules guiding their activity as a Court.' (P.C.I.J. Ser. B, p. 29).

The Court has considerable discretion in the organization of advisory proceedings. The practice of the Court (as well as that of the Permanent Court) indicates that the Court has approached the question of participation flexibly (Rosenne, The Law and Practice of the International Court, 19202005, pp. 1671-4). This was demonstrated, for example, in the most recent advisory opinion, Legal Consequences of the Construction of a Wall in the Occupied Palestinian Territory (I.C.J. Reports 2004, p. 136 at 141-2, paras. 4 and 5; and CR 2004/1, p. 19), in which the Court recognized the particular position and interests of Palestine in relation to the question put to the Court. 
As the Court has frequently recognized, equality of the parties and audi alteram partem are fundamental principles in all judicial proceedings (see, for example, Rosenne, loc.cit, pp. 1048-52). This includes advisory opinion proceedings (see Keith, The Extent of the Advisory Jurisdiction of the International Court of Justice, pp. 157-64).

The Court has recognised the need to uphold the principle of the equality of the parties in advisory proceedings where two or more parties are directly affected by the proceedings, in order to ensure the fairness of the proceedings. For example, in the Administrative Tribunal of the ILO (UNESCO) advisory opinion, the Court said that " $\mathrm{t}$ t]he judicial character of the Court requires that both sides directly affected by these proceedings should be in a position to submit their views and arguments to the Court' (I.C.J. Reports 1956, p.76 at 86).

In addition to the legal arguments that Kosovo will wish to make to the Court, Kosovo will be able to furnish the Court with relevant information essential to any consideration of the request. In particular, the Declaration of Independence of 17 February 2008 has to be seen against the background of the history of Kosovo, including events since 1989 and those leading directly to the Declaration of Independence

If and to the extent that it may be considered relevant in the present proceedings, I would request that this letter be regarded as constituting, exclusively for the purposes of these proceedings, the declaration referred to in Article 41 of the Rules of Court. 
I hereby inform you that my Government has nominated me as the Representative of the Republic of Kosovo for the purposes of the present proceedings.

For the reasons set out above, and on behalf of the Government of the Republic of Kosovo, I respectfully request the Court to invite the Republic of Kosovo, as a party that is directly interested and able to furnish relevant information, to participate in the proceedings, on a footing of equality with others, including the Republic of Serbia, both at the written stage and at any oral hearing.

Accept, Sir, the assurances of my highest consideration.
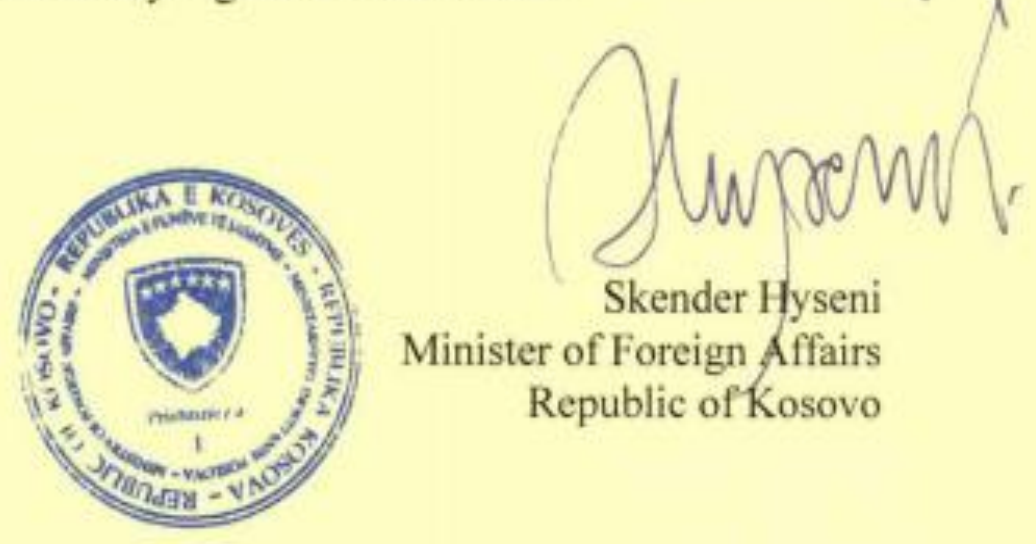

Minister of Foreign Affairs

Republic of Kosovo

H. E. Mr Philippe Couvreur

Registrar

International Court of Justice

Peace Palace

$2517 \mathrm{KJ}$ The Hague

Netherlands

Fonte: KOSOVO. Ministério dos Negócios Estrangeiros do. Opinião consultiva da declaração unilateral no Kosovo. Disponível em: <http://www.mfa-ks.net/?page=2,1>. Acesso em: 11 abr. 2017. 
ANEXO D - Resolução n. 3 do Conselho Nacional de Política Indigenista: demarcação de todas as terras indígenas do Brasil.

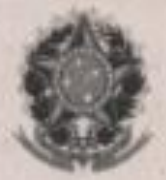 \\ MINISTÉRIO DA JUSTICA \\ Conselho Nacional de Politica Indigenista \\ Resolução n? 003 do Conselho Nacional de Politica Indigenista
}

Pela demarcação de todas as terras indigenas do Brasil.

O CONSELHO NACIONAL DE POLITICA INDIGENISTA, órgăo colegiado e consultivo da administração pública responsável pela elaboraçăo, acompanhamento e implementaçăo de politicas públicas voltadas aos povos indigenas, devidamente instituido pelo Decreto $n^{2} 8.583 / 15$, e instalado pela Portaria Ministerial $n^{0} 491$ de 27 abril de 2016, reunido em sessắo ordinária nos dia 28 e 29 de abril de 2016, no exercicio de suas atribuiçø̃es e atendendo disposiçōes aprovadas na 12 Conferéncia Nacional de Politica Indigenista, insta a Presidência da República Federativa do Brasil, ao Ministério da Justiça e a Fundaçăo Nacional do índio, a cumprir os ritos de todos os processos demarcatórios de terras indigenas que estăo pendentes no âmbito da FUNAI (Despacho de Relatório Circunstanciado de Identificação e Delimitação), do Ministério da Justiça (Portarias Declaratórias) e Presidência da República (Decretos de Homologaçăo), como estabelecidos pela legislaçäo pertinente e em vigor, a saber o Decreto $n^{2} 1.775 / 96$ e Portaria $n^{2} 14 / 96$ do Ministério da Justiça, em todas as regiōes do Brasil e năo apenas na Amazónia Legal. O Governo tem a obrigaçăo de cumprir o mandado constitucional estabelecido pelos Artigos 231 e 232 da Carta Magna assegurando a demarcação de todas as terras indigenas no Brasil, que tem força maior de direito originário, e jamais submeter a decisão ao aval de quaisquer outros órgð̌os da administraçăo e muito menos de interesses privados.

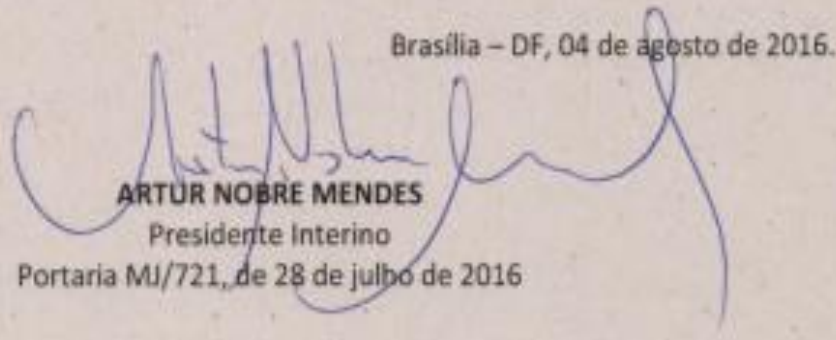

Fonte: BRASIL. Ministério da Justiça. Conselho Nacional de Política Indigenista. Resolução n.3. Pela demarcação de todas as terras indígenas do Brasil. Disponível em: $<$ http://www.funai.gov.br/arquivos/conteudo/presidencia/CNPI_Conselho/Atos_e_Normas/RE SOLUCOES/CNPI_2016_Resol003.pdf>. Acesso em: 11 abr. 2017. 
ANEXO E - Resolução n. 4 do Conselho Nacional de Política Indigenista: direito originário dos povos indígenas.

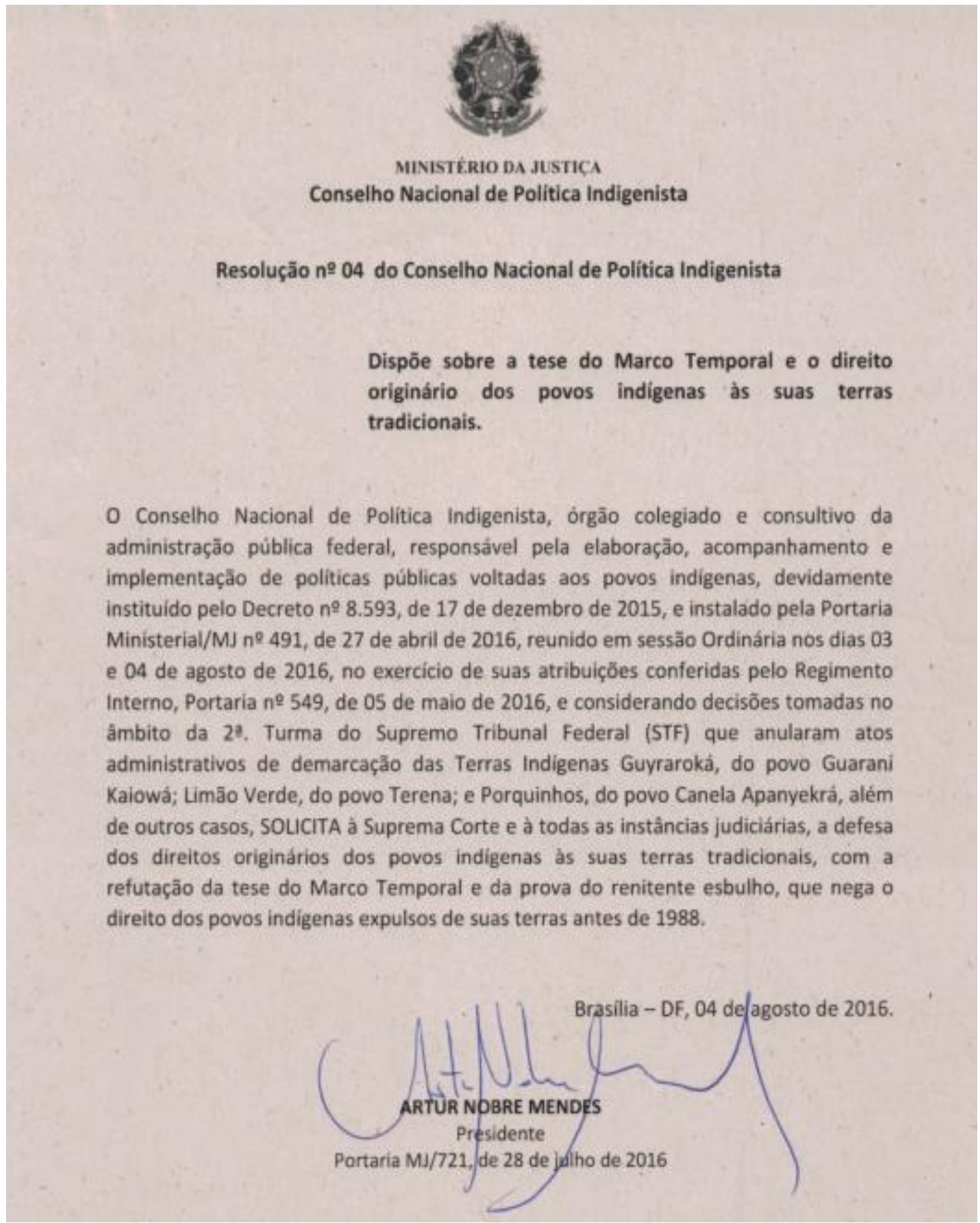

Fonte: BRASIL. Ministério da Justiça. Conselho Nacional de Política Indigenista. Resolução $n$. 4. Dispõe sobre a tese do Marco Temporal e o direito originário dos povos indígenas às suas terras tradicionais. Disponível em: <http://www.funai.gov.br/arquivos /conteudo/presidencia/CNPI_Conselho/Atos_e_Normas/RESOLUCOES/CNPI_2016_Resol00 4.pdf>. Acesso em: 11 abr. 2017. 
ANEXO F - Resolução n. 5 do Conselho Nacional de Política Indigenista: direito dos povos indígenas de se fazerem representar em processos judiciais.

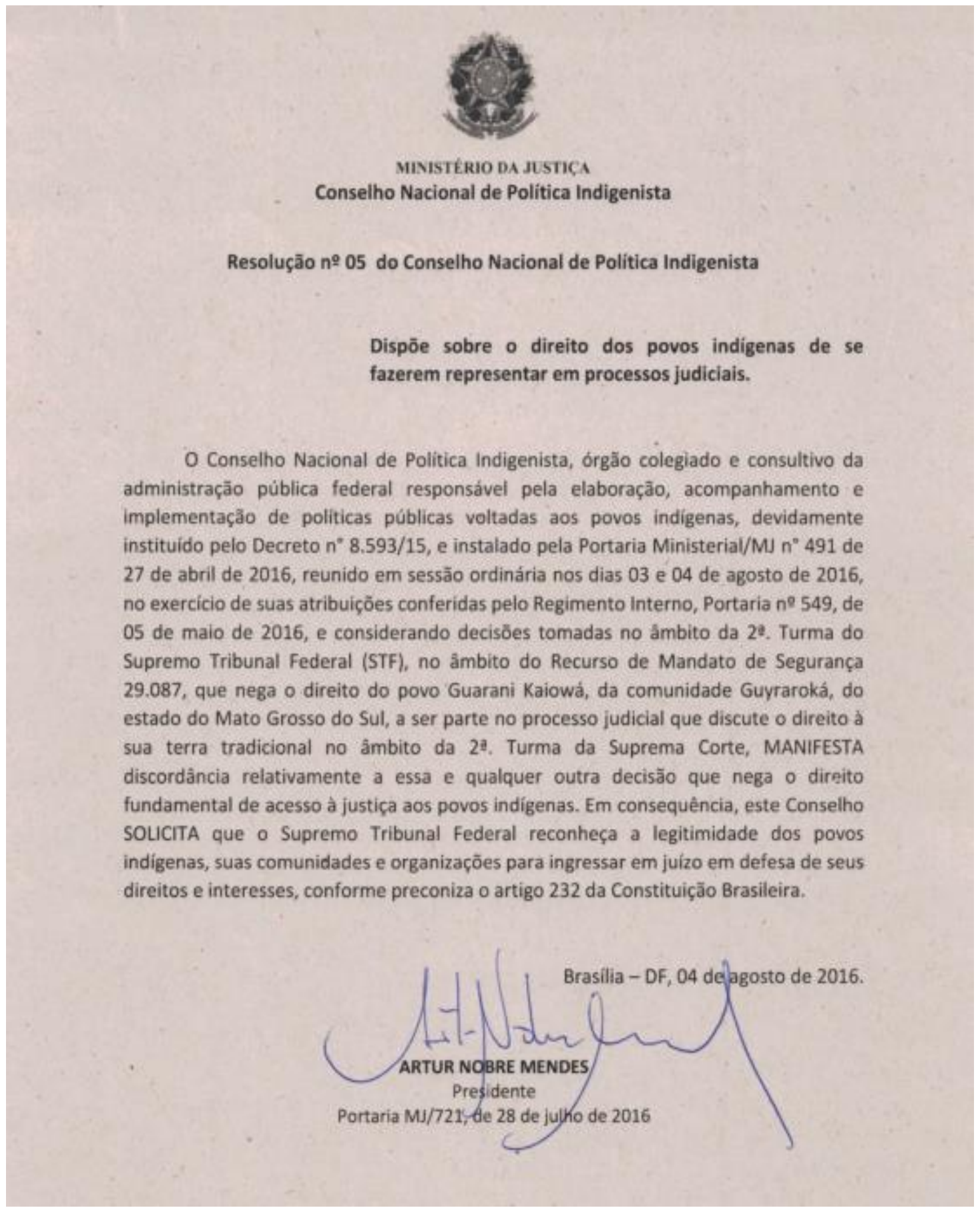

Fonte: BRASIL. Ministério da Justiça. Conselho Nacional de Política Indigenista. Resolução $n$. 5. Dispõe sobre o direito dos povos indígenas de se fazerem representar em processos judiciais. Disponível em: <http://www.funai.gov.br/arquivos/conteudo /presidencia/CNPI_Conselho/Atos_e_Normas/RESOLUCOES/CNPI_2016_Resol005.pdf >. Acesso em: 11 abr. 2017. 